Prepared in cooperation with the South Yakima Conservation District

\title{
Assessment of Eutrophication in the Lower Yakima River Basin, Washington, 2004-07
}

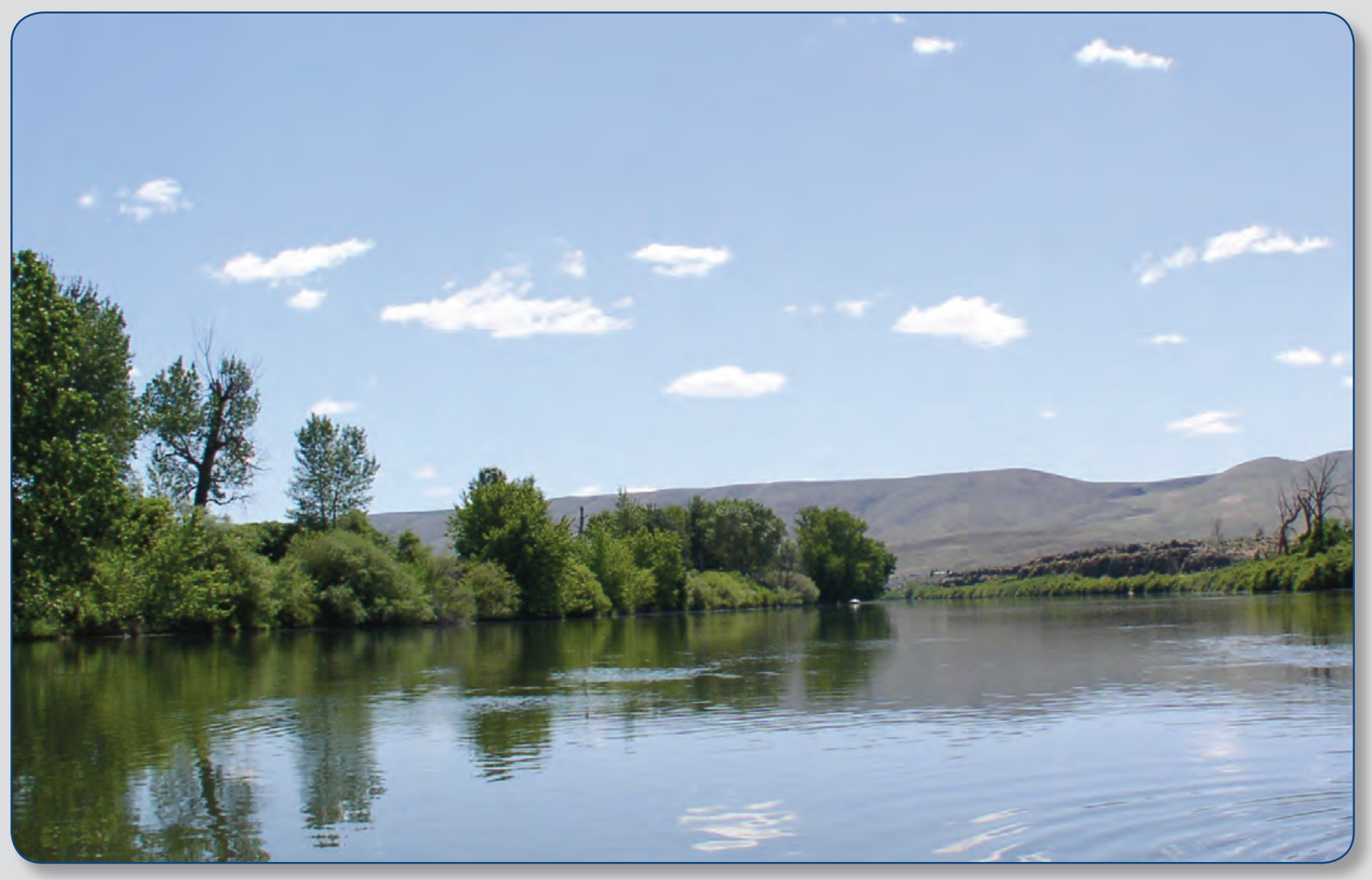

Scientific Investigations Report 2009-5078

U.S. Department of the Interior

U.S. Geological Survey 
Cover: Photograph of Yakima River looking upstream near Mabton, Washington.

(Photograph taken by Marie Zuroske, South Yakima Conservation District, June, 2004.) 


\section{Assessment of Eutrophication in the Lower Yakima River Basin, Washington, 2004-07}

By By Daniel R. Wise, U.S. Geological Survey; Marie L. Zuroske, formerly with South Yakima Conservation District; Kurt D. Carpenter and Richard L. Kiesling, U.S. Geological Survey

Prepared in cooperation with the South Yakima Conservation District

Scientific Investigations Report 2009-5078 


\title{
U.S. Department of the Interior \\ KEN SALAZAR, Secretary \\ U.S. Geological Survey \\ Suzette M. Kimball, Acting Director
}

\section{U.S. Geological Survey, Reston, Virginia: 2009}

\author{
For more information on the USGS - the Federal source for science about the Earth, its natural and living resources, \\ natural hazards, and the environment, visit http://www.usgs.gov or call 1-888-ASK-USGS \\ For an overview of USGS information products, including maps, imagery, and publications, \\ visit http://www.usgs.gov/pubprod \\ To order this and other USGS information products, visit http://store.usgs.gov
}

\begin{abstract}
Any use of trade, product, or firm names is for descriptive purposes only and does not imply endorsement by the U.S. Government.

Although this report is in the public domain, permission must be secured from the individual copyright owners to reproduce any copyrighted materials contained within this report.
\end{abstract}

Suggested citation:

Wise, D.R., Zuroske, M.L., Carpenter, K.D., and Kiesling, R.L., 2009, Assessment of eutrophication in the Lower Yakima River Basin, Washington, 2004-07: U.S. Geological Survey Scientific Investigations Report 2009-5078, 108 p. 


\section{Contents}

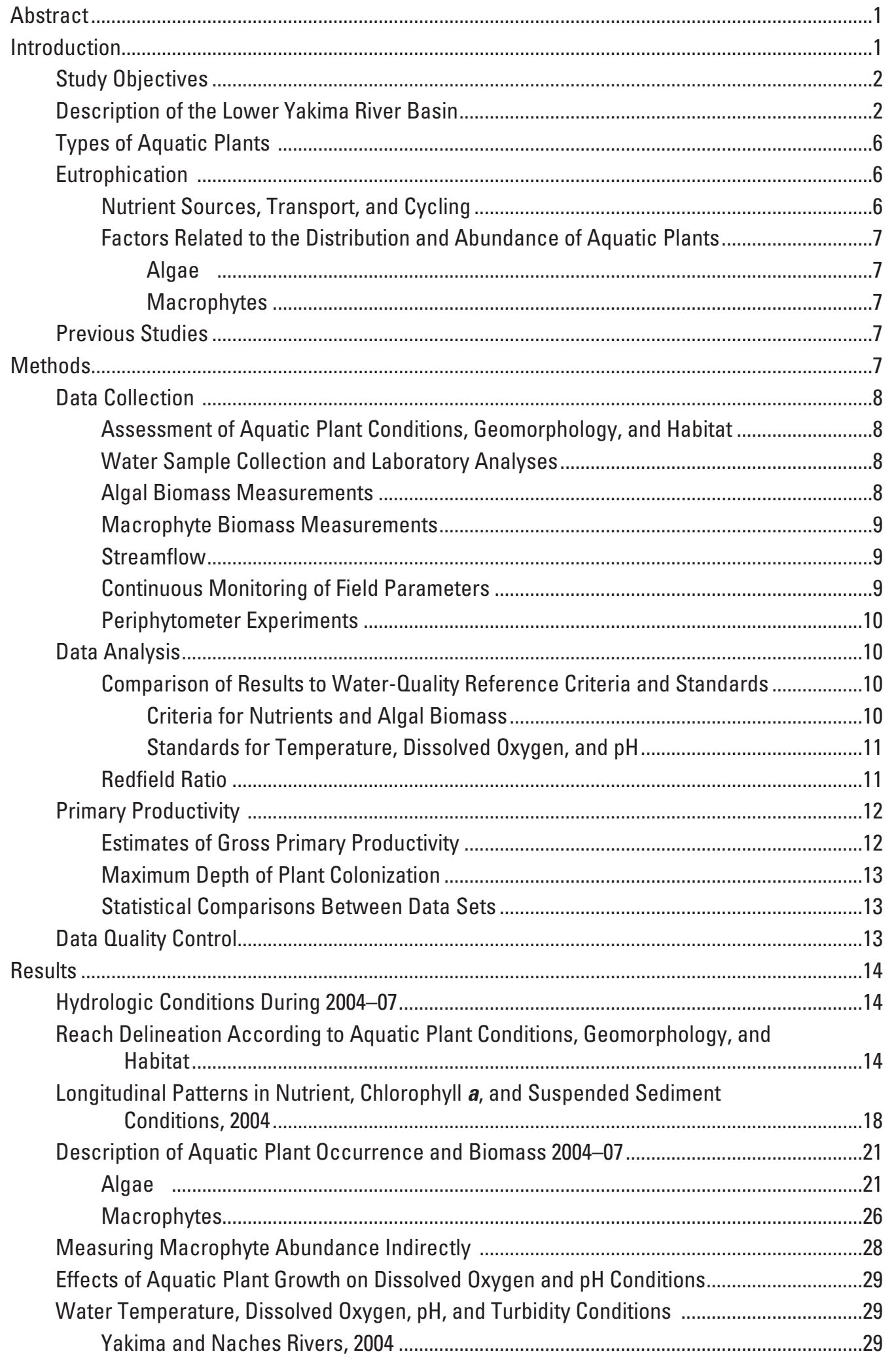




\section{Contents-Continued}

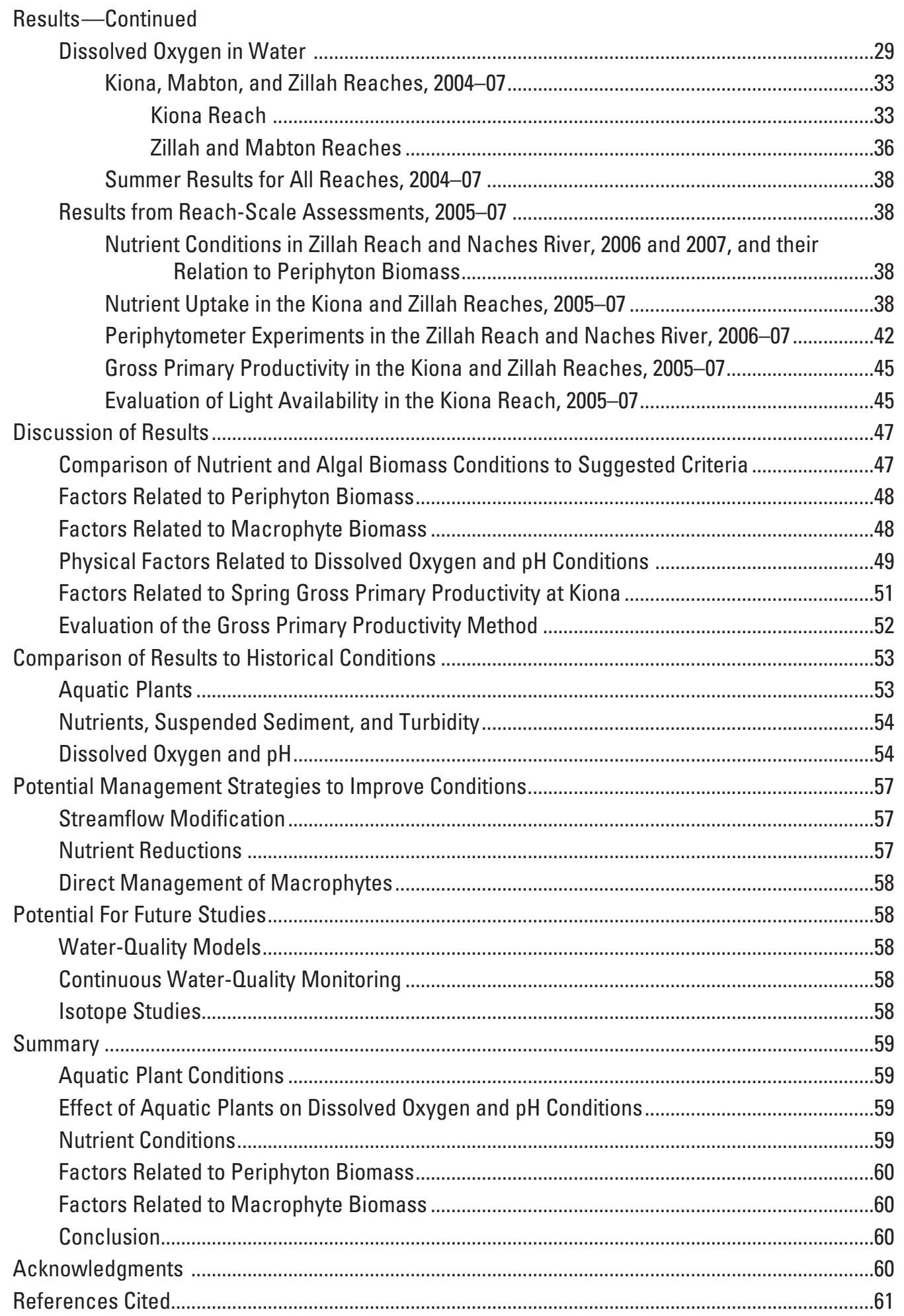




\section{Contents-Continued}

Appendix A. Study Design for the Lower Yakima River, 2005-07

. .83

Appendix B. Description of Methodology Used to Estimate Reaeration Coefficients in the Yakima River, Washington, 2005-07.

Appendix C. Results from Quality Control Analysis for Discrete Water-Quality Sampling in the Yakima River, Washington, 2004-07

Appendix D. Results from Quality Control Analysis for Continuous Monitoring of Water Temperature, Specific Conductance, Dissolved Oxygen, pH, Turbidity, and Chlorophyll $\boldsymbol{a}$ in the Yakima River, Washington, 2004-07

Appendix E. Mass Balances for Instantaneous Streamflows, Total Nitrogen Loads, Total Phosphorus Loads, and Suspended Sediment Loads in the Main Stem, Selected Major Tributaries, and Canals, Yakima River Basin, Washington, July 26-29, 2004.

\section{Figures}

Figure 1. Map showing Yakima River basin, Washington............................ 3

Figure 2. Map showing study area in the lower Yakima River basin, Washington $\ldots \ldots \ldots \ldots .4$

Figure 3. Map showing typical irrigation-season streamflow and canal discharge for the lower Yakima River basin, Washington

Figure 4. Diagram showing hypothetical water cycle showing potential pathways for nutrients to enter streams and rivers

Figure 5. Graph showing daily mean streamflow for Yakima River at Kiona, Washington, March 1-September 30, 1906-2007 and 2004-07

Figure 6. Graphs showing results from 2004 assessment of the lower Yakima River, including stream width, maximum water depth and maximum surface velocity, and elevation profile, habitat and substrate types, and macrophyte abundance in the lower Yakima River, Washington, June 14-18, 2004

Figure 7. Graphs showing results from Lagrangian synoptic sampling of nutrients, chlorophyll a, and suspended sediment, lower Yakima River, Washington, July 26-July 29, 2004

Figure 8. Graphs showing instantaneous streamflow and loads of total nitrogen and total phosphorus in the lower Yakima River, Washington, July 26-29, 2004

Figure 9. Graphs showing periphytic algal biomass measured in the Zillah reach between RM 103 and 87, Yakima River, July-October 2006 and July-September 2007, and in the Naches River, Washington, between RM 11.5 and 2.8, July-September 2007

Figure 10. Graphs showing relation between macrophyte biomass and water depth and mid-depth stream velocity in the Kiona reach near RM 18, Yakima River, Washington 2005-07

Figure 11. Graphs showing streamflow, dissolved oxygen concentrations, dissolved oxygen saturation, pH levels, total chlorophyll, turbidity, and temperature results from continuous monitoring in the Yakima River at Kiona (RM 30), Mabton (RM 55), and Zillah (RM 87), Washington, March 1-September 30, 2004-07 


\section{Figures-Continued}

Figure 12. Graphs showing summary of results from short-term continuous water-quality monitoring for water temperature, dissolved oxygen, and $\mathrm{pH}$, Yakima and Naches Rivers, Washington, April-October 2004

Figure 13. Graphs showing summary of results from short-term continuous water-quality monitoring for turbidity, Yakima and Naches Rivers, Washington, April-0ctober 2004

Figure 14. Graphs showing summary of continuous monitoring results for daily maximum water temperature, daily minimum dissolved oxygen concentration, and daily maximum pH, Yakima River at Kiona (RM 30),

Washington, March 1-September 30, 2004-07

Figure 15. Graphs showing summary of continuous monitoring results for daily maximum water temperature, daily minimum dissolved oxygen concentration, and daily maximum pH, Yakima River at Mabton (RM 55) and Zillah (RM 87), Washington, March 1-September 30, 2005-07

Figure 16. Graphs showing summary of daily maximum water temperature, daily minimum dissolved oxygen concentration, and daily maximum $\mathrm{pH}$ for the Yakima River at Kiona (RM 30), Mabton (RM 55), and Zillah (RM 87), Washington, July 1-August 31, 2004-07

Figure 17. Graphs showing concentrations of dissolved inorganic nitrogen and soluble reactive phosphorus measured in the Zillah reach of the Yakima River, between RM 103 and 87 and in the Naches River between RM 11.5 and 2.8, Washington, July-0 ctober 2006-07

Figure 18. Graphs showing concentrations of dissolved nitrite plus nitrate and soluble reactive phosphorus measured in the surface water and pore water of the Zillah reach between RM 103 and RM 87, Yakima River, Washington, 2005-07

Figure 19. Graphs showing relation between periphytic algal biomass (chlorophyll a) and dissolved inorganic nitrogen and soluble reactive phosphorus in the Zillah reach of the Yakima River between RM 103 and 87, July-October 2006 and July-September 2007, and in the Naches River between RM 11.5 and 2.8, Washington, July-September 2007

Figure 20. Graphs showing relation between periphytic algal biomass (ash-free dry mass) and (A) dissolved inorganic nitrogen and (B) soluble reactive phosphorus in the Zillah reach of the Yakima River between RM 103 and 87, July-October 2006 and July-September 2007, and in the Naches River between RM 11.5 and 2.8, Washington, July-September 2007

Figure 21. Graphs showing concentrations of dissolved inorganic nitrogen and soluble reactive phosphorus measured in the Zillah reach at RM 103 and 87, Yakima River, Washington, July-September, 2006-07

Figure 22. Graphs showing results from periphytometer experiments conducted in the Zillah reach between RM 103 and RM 87, Yakima River, July 26-August 9, 2006, September 19-0ctober 3, 2006, August 23-September 3, 2007, and in the Naches River, Washington between RM 12.2 and 2.8, 


\section{Figures-Continued}

Figure 23. Graphs showing results from continuous water-quality monitoring during periphytometer experiments in the Zillah reach of the Yakima River, Washington between RM 103 and 87 and in the Naches River, Washington between RM 11.5 and 2.8 for water temperature, dissolved oxygen concentration, and pH, July 26-August 9, 2006, September 19-0ctober 3, 2006, July 17-July 31, 2007, and August 23-September 3, 2007

Figure 24. Graphs showing summary of daily estimates of gross primary productivity for Yakima River at Kiona (RM 30), Washington, March 1-June 30, 2005-07 and Yakima River at Zillah (RM 87) and Kiona (RM 30), Washington, July 1-August 30, 2005-07.

Figure 25. Graph showing daily mean gage height and maximum depths of plant colonization estimated at RM 30 and RM 20, Yakima River, Washington March 1-September 30, 2005-07

Figure 26. Graph showing estimated maximum depths of plant colonization and instantaneous turbidity between RM 116 and RM 8, Yakima River, and between RM 12 and RM 3.5, Naches River, Washington, March 1September 30, 2005-07

Figure 27. Graph showing comparison between fitted and actual daily minimum dissolved oxygen concentrations for the Yakima River at Kiona (RM 30),

Washington, March 1-September 30, 2004-07

Figure 28. Graphs showing relation between gross primary productivity and daily mean streamflow and daily median turbidity for the Yakima River at Kiona (RM 30), Washington, March 1-June 30, 2005-07

Figure 29. Graph showing spring streamflow and U.S. Geological Survey field notes for the Yakima River at Kiona (RM 30), Washington, March 1-June 30, 1906-07

Figure 30. Graphs showing concentrations of dissolved inorganic nitrogen, soluble reactive phosphorus, and suspended sediment measured at the Yakima River at Kiona (RM 30), Washington, July 1-September 30, 1975-2000 and 2001-03, and July 29, 2004

Figure 31. Graphs showing instantaneous streamflows, total nitrogen loads and concentrations, and total phosphorus loads and concentrations in the Yakima River, Washington, July 26-29, 2004, and July 26-29, 1988 56

Figure 32. Graph showing summary of turbidity monitoring, Yakima River at Kiona (RM 30), Washington, 1978-2000 and 2004-07 


\section{Tables}

Table 1. Potential factors affecting algal biomass given adequate-to-high nutrient supply and nontoxic conditions

Table 2. Reference conditions for nutrients suggested by the U.S. Environmental Protection Agency for streams in the Yakima River basin, Washington

Table 3. Qualitative descriptions of aquatic plant occurrence by river mile for the lower Yakima River, Washington, June 14-18, 2004

Table 4. Description of geomorphology and habitat, irrigation diversions, tributary and agricultural returns, light availability, aquatic plant growth, and nutrient concentrations in three reaches of the lower Yakima River, Washington, 2004-07

Table 5. Periphyton biomass in the lower Yakima and Naches Rivers, Washington, 2005-07 21

Table 6. Planktonic (water column) chlorophyll a in the lower Yakima and Naches Rivers, Washington, 2004-05.

Table 7. Total nitrogen and total phosphorus content of macrophyte tissues collected in the Zillah reaach (near river mile 87) and the Kiona reach (near river mile 21) of the Yakima River, Washington, August 30-September 2, 2005.

Table 8. Summary of macrophyte biomass measured in the Kiona reach of the Yakima River, Washington, near river mile 21, 2005-07

Table 9. Summary of water temperature, dissolved oxygen, and $\mathrm{pH}$ conditions in the Yakima River, Washington, March 1-June 30 and July 1-September 30, 2004-07

Table 10. Percentage of days and percentage of time when threshold values were exceeded for daily maximum water temperature, daily mean turbidity, daily minimum dissolved oxygen concentration, and daily maximum $\mathrm{pH}$, Yakima River at Kiona, Washington, 2004-07. ...

Table 11. Summary of continuous water-quality monitoring for water temperature, dissolved oxygen concentration, and $\mathrm{pH}$, in the Zillah reach between RM 103 and 87, Yakima River, Washington, July 26-August 9, 2006, July 17-July 31, 2007, and August 23-September 3, 2007

Table 12. Comparison of nutrient and algal biomass results to suggested U.S. Environmental Protection Agency reference conditions and algal biomass nuisance levels for the lower Yakima and Naches Rivers, July 1-September 30, 2004-07.

Table 13. Linear relations between daily minimum dissolved oxygen concentration and maximum water temperature on the previous day, Yakima River at Kiona (RM 30), Mabton (RM 55), and Zillah (RM 87), Washington, March 1-September 30, 2004-07.

Table 14. Linear relations between gross primary productivity and environmental factors in the Yakima River at Kiona (RM 30), Washington, March 1-June 30, 2005-07

Table 15. Data collection activities and site locations in the lower Yakima River basin, Washington, 2004-07 


\section{Conversion Factors, Datums, and Abbreviations and Acronyms}

Inch/Pound to SI

\begin{tabular}{lcl}
\hline \multicolumn{1}{c}{ Multiply } & By & \multicolumn{1}{c}{ To obtain } \\
\hline foot $(\mathrm{ft})$ & Length & \\
mile $(\mathrm{mi})$ & 0.3048 & meter $(\mathrm{m})$ \\
& 1.609 & kilometer $(\mathrm{km})$ \\
\hline square ${\text { mile }\left(\mathrm{mi}^{2}\right)}$ & Area & \\
\hline & 2.590 & square kilometer $\left(\mathrm{km}^{2}\right)$ \\
\hline foot per second $(\mathrm{ft} / \mathrm{s})$ & Velocity & \\
\hline & 0.3048 & meter per second $(\mathrm{m} / \mathrm{s})$ \\
\hline cubic foot per second $\left(\mathrm{ft}^{3} / \mathrm{s}\right)$ & Flow rate & \\
\hline & 0.02832 & cubic meter per second $\left(\mathrm{m}^{3} / \mathrm{s}\right)$ \\
\hline pound, avoirdupois $(\mathrm{lb})$ & Mass & \\
ton per day (ton $/ \mathrm{d})$ & 0.4536 & kilogram $(\mathrm{kg})$ \\
\hline
\end{tabular}

SI to Inch/Pound

\begin{tabular}{lll}
\hline \multicolumn{1}{c}{ Multiply } & \multicolumn{1}{c}{ By } & \multicolumn{1}{c}{ To obtain } \\
\hline & Length & \\
\hline centimeter $(\mathrm{cm})$ & 0.3937 & inch (in.) \\
millimeter $(\mathrm{mm})$ & 0.03937 & inch (in.) \\
meter $(\mathrm{m})$ & 3.281 & foot $(\mathrm{ft})$ \\
kilometer $(\mathrm{km})$ & 0.6214 & mile (mi) \\
\hline & Area & \\
\hline square meter $\left(\mathrm{m}^{2}\right)$ & 10.76 & square foot $\left(\mathrm{ft}^{2}\right)$ \\
\hline & Mass & \\
\hline gram $(\mathrm{g})$ & 0.03527 & ounce, avoirdupois $(\mathrm{oz})$ \\
milligram $(\mathrm{mg})$ & 0.00003527 & ounce, avoirdupois $(\mathrm{oz})$ \\
\hline
\end{tabular}

Temperature in degrees Celsius $\left({ }^{\circ} \mathrm{C}\right)$ may be converted to degrees Fahrenheit $\left({ }^{\circ} \mathrm{F}\right)$ as follows:

$$
{ }^{\circ} \mathrm{F}=\left(1.8 x^{\circ} \mathrm{C}\right)+32 .
$$

Temperature in degrees Fahrenheit $\left({ }^{\circ} \mathrm{F}\right)$ may be converted to degrees Celsius $\left({ }^{\circ} \mathrm{C}\right)$ as follows:

$$
{ }^{\circ} \mathrm{C}=\left({ }^{\circ} \mathrm{F}-32\right) / 1.8 \text {. }
$$

Concentrations of chemical constituents in water are given in milligrams per liter (mg/L).

Periphyton biomass results are given in milligrams per square meter $\left(\mathrm{mg} / \mathrm{m}^{2}\right)$ for chlorophyll a and grams per square meter $\left(\mathrm{g} / \mathrm{m}^{2}\right)$ for ash-free dry mass.

Periphyton accumulation rates are given in milligrams per square meter per day $\left(\mathrm{mg} / \mathrm{m}^{2}\right.$-day) for chlorophyll $a$.

Water column planktonic chlorophyll a results are given in micrograms per liter $(\mu \mathrm{g} / \mathrm{L})$. 


\section{Conversion Factors, Datums, and Abbreviations and Acronyms-Continued}

Datums

Vertical coordinate information is referenced to the North American Vertical Datum of 1988 (NAVD 88).

Horizontal coordinate information is referenced to the North American Datum of 1983 (NAD 83).

Elevation, as used in this report, refers to distance above the vertical datum.

Abbreviations and Acronyms

$\begin{array}{ll}\text { AFDM } & \text { ash-free dry mass } \\ \text { ANOVA } & \text { analysis of variance } \\ \mathrm{Chl} a & \text { Chlorophyll } a \\ \mathrm{C}_{6} \mathrm{H}_{12} \mathrm{O}_{6} & \text { glucose } \\ \mathrm{CO}_{2} & \text { carbon dioxide } \\ \text { d } & \text { day } \\ \mathrm{DIN} & \text { dissolved nitrite plus nitrate and dissolved ammonia } \\ \mathrm{FNU} & \text { Formazin Nephelometric Unit } \\ \mathrm{GF} / \mathrm{F} & \text { glass fiber filters } \\ \mathrm{GPP} & \text { gross primary productivity } \\ \mathrm{H}_{2} \mathrm{O} & \text { water } \\ \mathrm{N} & \text { nitrogen } \\ \mathrm{NDS} & \text { nutrient-diffusing substrate } \\ \mathrm{NTU} & \text { Nephelometric Turbidity Unit } \\ \mathrm{NO} \mathrm{H}_{3}-\mathrm{N} & \text { nitrate nitrogen } \\ \mathrm{O}_{2} & \text { gaseous oxygen } \\ \mathrm{P} & \text { phosphorus } \\ \mathrm{PAR} & \text { photosynthetically active radiation } \\ \mathrm{PO} \mathrm{O}_{4}-\mathrm{P} & \text { phosphate phosphorus } \\ \mathrm{OC} & \text { quality control } \\ \mathrm{RM} & \text { river mile } \\ \mathrm{SRP} & \text { soluble reactive phosphorus } \\ \mathrm{TKN} & \text { total Kjeldahl nitrogen } \\ \mathrm{TMDL} & \text { total maximum daily load } \\ \mathrm{USEPA} & \text { U.S. Environmental Protection Agency } \\ \mathrm{USGS} & \text { U.S. Geological Survey } \\ \mathrm{WA} \mathrm{DOE} & \text { Washington Department of Ecology } \\ \mathrm{Z}_{\mathrm{c}} & \text { maximum depth of macrophyte colonization } \\ & \end{array}$




\title{
Assessment of Eutrophication in the Lower Yakima River Basin, Washington, 2004-07
}

\author{
By Daniel R. Wise', Marie L. Zuroske' ${ }^{2}$, Kurt D. Carpenter', and Richard L. Kiesling'
}

\section{Abstract}

In response to concerns that excessive plant growth in the lower Yakima River in south-central Washington was degrading water quality and affecting recreational use, the U.S. Geological Survey and the South Yakima Conservation District conducted an assessment of eutrophication in the lower 116 miles of the river during the 2004-07 irrigation seasons (March-October). The lower Yakima River was divided into three distinct reaches based on geomorphology, habitat, aquatic plant and water-quality conditions. The Zillah reach extended from the upstream edge of the study area at river mile (RM) 116 to RM 72, and had abundant periphyton growth and sparse macrophyte growth, the lowest nutrient concentrations, and moderately severe summer dissolved oxygen and $\mathrm{pH}$ conditions in 2005. The Mabton reach extended from RM 72 to RM 47, and had sparse periphyton and macrophyte growth, the highest nutrient conditions, but the least severe summer dissolved oxygen and $\mathrm{pH}$ conditions in 2005. The Kiona reach extended from RM 47 to RM 4, and had abundant macrophyte and epiphytic algae growth, relatively high nutrient concentrations, and the most severe summer dissolved oxygen and $\mathrm{pH}$ conditions in 2005.

Nutrient concentrations in the lower Yakima River were high enough at certain times and locations during the irrigation seasons during 2004-07 to support the abundant growth of periphytic algae and macrophytes. The metabolism associated with this aquatic plant growth caused large daily fluctuations in dissolved oxygen concentrations and $\mathrm{pH}$ levels that exceeded the Washington State water-quality standards for these parameters between July and September during all 4 years, but also during other months when streamflow was unusually low. The daily minimum dissolved oxygen concentration was strongly and negatively related to the preceding day's maximum water temperature-information that could prove useful if a dissolved oxygen predictive model is developed for the lower Yakima River.

Periphytic algal growth generally was not nutrientlimited and frequently reached nuisance levels in the Zillah reach, where some surface-water nutrient concentrations were below the reference concentrations suggested by the

\footnotetext{
${ }^{1}$ U.S. Geological Survey

${ }^{2}$ formerly with South Yakima Conservation District
}

U.S. Environmental Protection Agency. Although lowering nutrient concentrations in this reach might limit periphytic algal growth enough to improve dissolved oxygen and $\mathrm{pH}$ conditions, ground water inflow at some locations might still provide an adequate supply of nutrients for periphytic algal growth.

Macrophyte growth in the Kiona reach was dominated by water stargrass (Heteranthera dubia), was far greater compared to the other two reaches, varied greatly between years, and was negatively related to greater spring runoff due to lower light availability. Lowering nutrient concentrations in the Kiona reach might not impact the level of macrophyte growth because macrophytes with extensive root systems such as water stargrass can get nutrients from river sediment. In addition, the results from this study did not indicate any nutrient uptake by the macrophytes from the water column (nutrient uptake from the sediment was not examined). Creating the prolonged turbid and deep conditions during spring necessary to suppress macrophyte growth in this reach would not be possible in years with low streamflow. In addition, because of the relatively stable substrate present in much of this reach, the macrophyte root systems would likely not be disturbed under all but the most extremely high streamflows that occur in the lower Yakima River.

\section{Introduction}

During summer 2001, unusually dense and extensive patches of rooted aquatic plants (macrophytes) were observed in the lower Yakima River in south-central Washington near Kiona at river mile (RM) 30 by various agency personnel and local residents. By 2003, excessive plant growth produced nuisance conditions in the lower river near Kiona that impaired recreational use and was suspected of causing conditions (low dissolved oxygen concentrations and high $\mathrm{pH}$ ) that might adversely affect fish species in the river. In response to these concerns, the USGS and the South Yakima Conservation District conducted an assessment of eutrophication (nutrient enrichment) in the lower $116 \mathrm{mi}$ of the Yakima River during the 2004-07 irrigation seasons. This study evaluated the water-quality affects from algae and 
macrophytes in the Yakima River, and the results gained can be used by water-quality managers and other stakeholders in the Yakima basin during water-quality improvement efforts, such as Total Maximum Daily Load (TMDL) development and implementation.

\section{Study Objectives}

This report presents the results of a four year cooperative study of nutrient enrichment in the lower Yakima River basin. The primary objectives of the study were to (1) characterize distinct reaches in the lower $116 \mathrm{mi}$ of the Yakima River based on aquatic plant conditions, geomorphology, and habitat, (2) characterize nutrient and suspended-sediment conditions and calculate a load balance on nutrients and suspended sediment, including major tributaries, drains, and wastewater treatment plants to identify the major sources of nutrients, (3) characterize the extent and severity of exceedences of the Washington State water-quality standards for water temperature, dissolved oxygen, and $\mathrm{pH}$, (4) determine the important factors related to the spatial and temporal patterns in aquatic plant and water-quality conditions, and (5) compare current aquatic plant and water-quality conditions to historical conditions.

\section{Description of the Lower Yakima River Basin}

The Yakima River drains a $6,155 \mathrm{mi}^{2}$ basin on the east side of the Cascade Range in south-central Washington (fig. 1). The mean annual precipitation ranges from about $140 \mathrm{in.}$ in the higher mountains to less than $10 \mathrm{in}$. in the lower basin and, because only 20 to 40 percent of the annual precipitation occurs during the growing season between March and October, most crops need to be irrigated. The area is one of the most intensively irrigated areas in the United States, and surface-water diversions for irrigation are equivalent to about 60 percent of the annual streamflow for the basin (Morace and others, 1999). A major Bureau of Reclamation irrigation project includes 6 large storage reservoirs in the northwestern part of the basin that were constructed between 1908 and 1933 and 14 major diversions from the main-stem Yakima River that feed 6 major irrigation-district projects and numerous small irrigation systems (Rinella and others, 1992).

The lower Yakima River basin (fig. 2) encompasses $2,500 \mathrm{mi}^{2}$ and is separated from the upper basin by a natural break in Ahtanum Ridge called Union Gap, located at RM 106. The landscape of the lower basin reflects the extent of irrigated agriculture - irrigated crops dominate near the lowlands and small hills close to the river, and sagebrush and dryland grasses dominate in the uplands. Irrigated crops include fruits, grapes, and specialty crops such as hops and mint (Fuhrer and others, 2004). The dairy and beef industries have rapidly expanded in the lower basin since the 1990s (Fuhrer and others, 2004). The city of Yakima, located immediately upstream of Union Gap, is by far the largest city in the basin with a population of about 75,000 , but the lower basin also includes many towns and small cities that depend on the agricultural economy for their livelihood. The Yakama Nation is in the southwest part of the basin and extends from the Yakima River to the crest of the Cascade Range.

The lower Yakima River is a highly managed system operated to meet diverse, often competing needs, including irrigation, fish habitat, recreation, flood control, and power generation. Flow varies widely in the river, diversions, and return drains from month to month and year to year. During the irrigation season from March through October this intensive management results in flows that are substantially different than those that would occur naturally in an unmanaged, snowmelt-dominated river in a semiarid climate. Peak flows in the lower Yakima River change abruptly during the irrigation season between reaches as water is diverted and returned to the river (fig. 3). Irrigation diversions begin in March, when snowmelt from the Cascades is typically the major source of water to the river. The snowmelt period generally ends in June when the stored water in reservoirs is released. Reservoir releases continue through the end of the irrigation season in late October.

Prior to the development of major irrigation projects in the Yakima River basin in the early 1900s, the Yakima River was one of the largest anadromous fish producers in the Columbia River basin. Much of the decrease in fish population in the $20^{\text {th }}$ century has been attributed to fish-passage problems and habitat restrictions associated with irrigation development in the basin, overfishing in the Pacific Ocean, Columbia and Yakima Rivers, and hydropower development on the Columbia River. Since 1980, however, improvements have been made in conditions for spawning, rearing, downstream migration of juvenile fish, and the upstream migration of adults in the Yakima River (Rinella and others, 1992).

Although the lower Yakima River is used primarily as a migration corridor by salmonids (steelhead, spring Chinook, and coho salmon) to access spawning areas in the upper river and tributaries, fall Chinook spawning grounds mostly are located within the lower river. Steelhead populations in the Yakima River basin are included in the Mid-Columbia Distinct Population Segment, and are listed as threatened under the Endangered Species Act (National Marine Fisheries Service, 2008). Based on known life histories of the fish species that pass through the lower Yakima River, the critical period for anadromous fish is during spring and autumn-ending around mid-June for the spring out-migration and starting in midSeptember for the autumn up-migration. Pacific lampreys spawn during spring and early summer months and have a migration period from March through October. Other native fish, such as those in the nonanadromous lamprey, minnow, sucker, and sculpin families, also reside in the lower Yakima River (Richard Visser, Washington Department of Fish and Wildlife, written commun., 2008). 


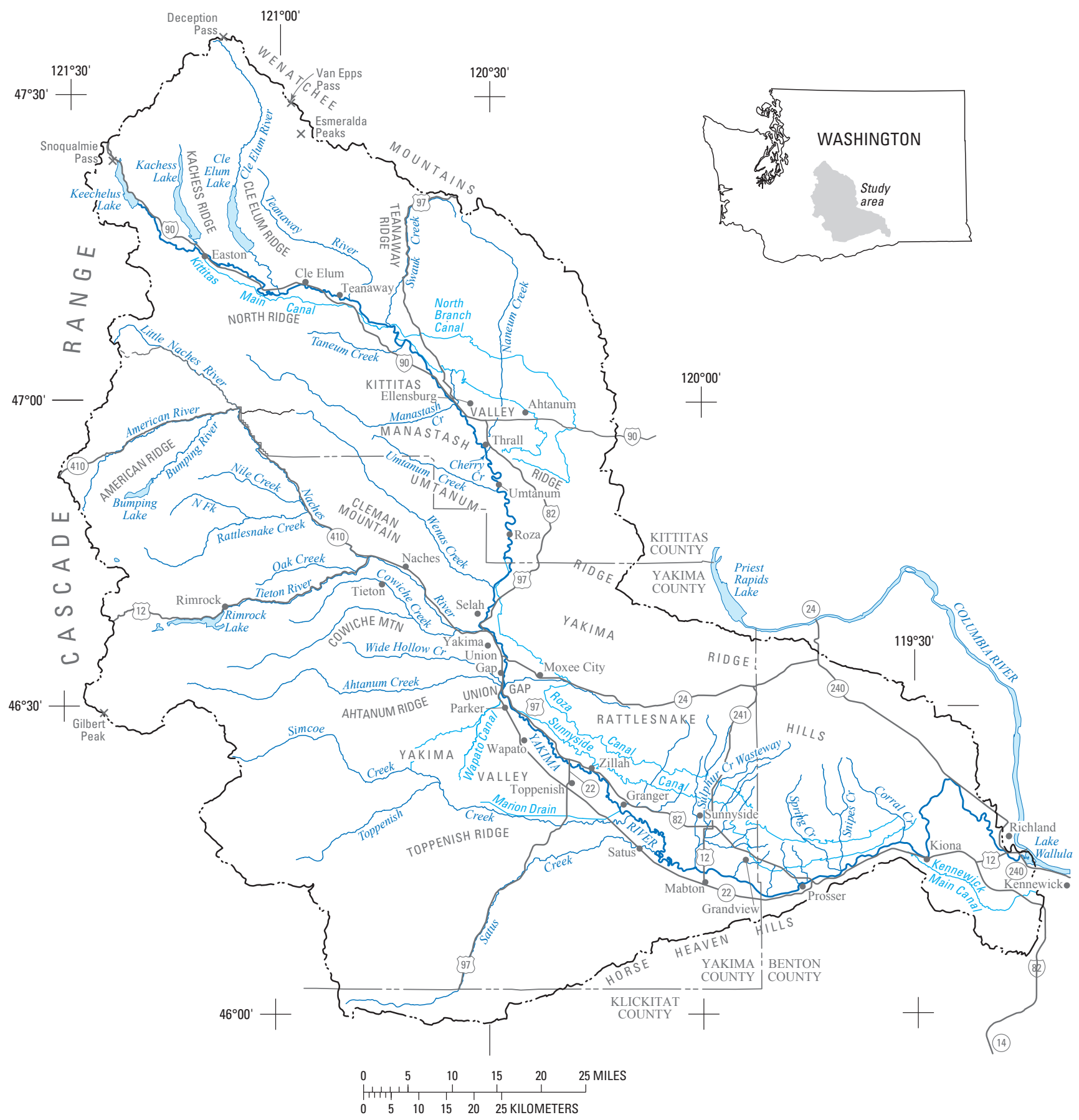

Figure 1. Yakima River basin, Washington. 


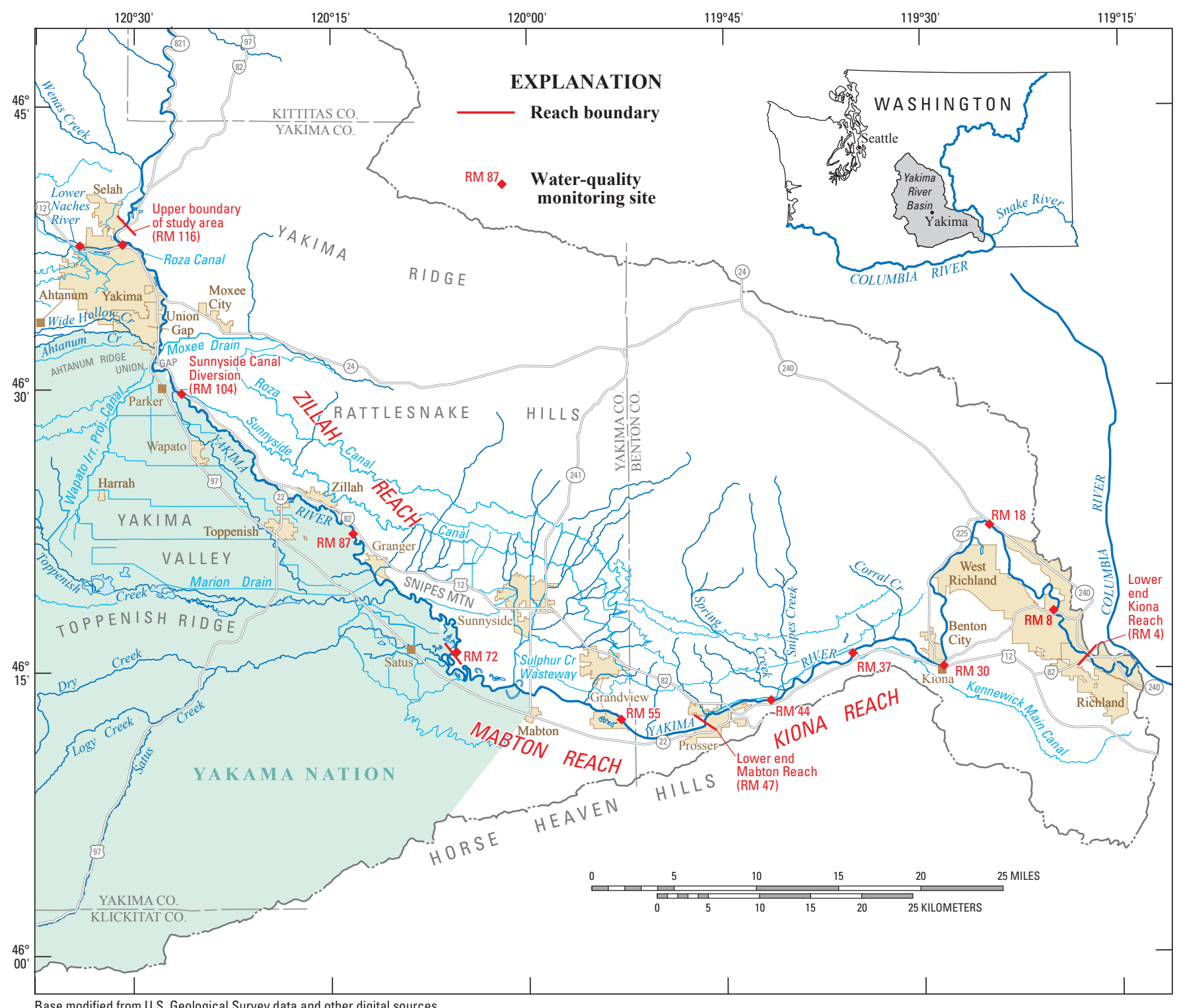

Figure 2. Study area in the lower Yakima River basin, Washington. 


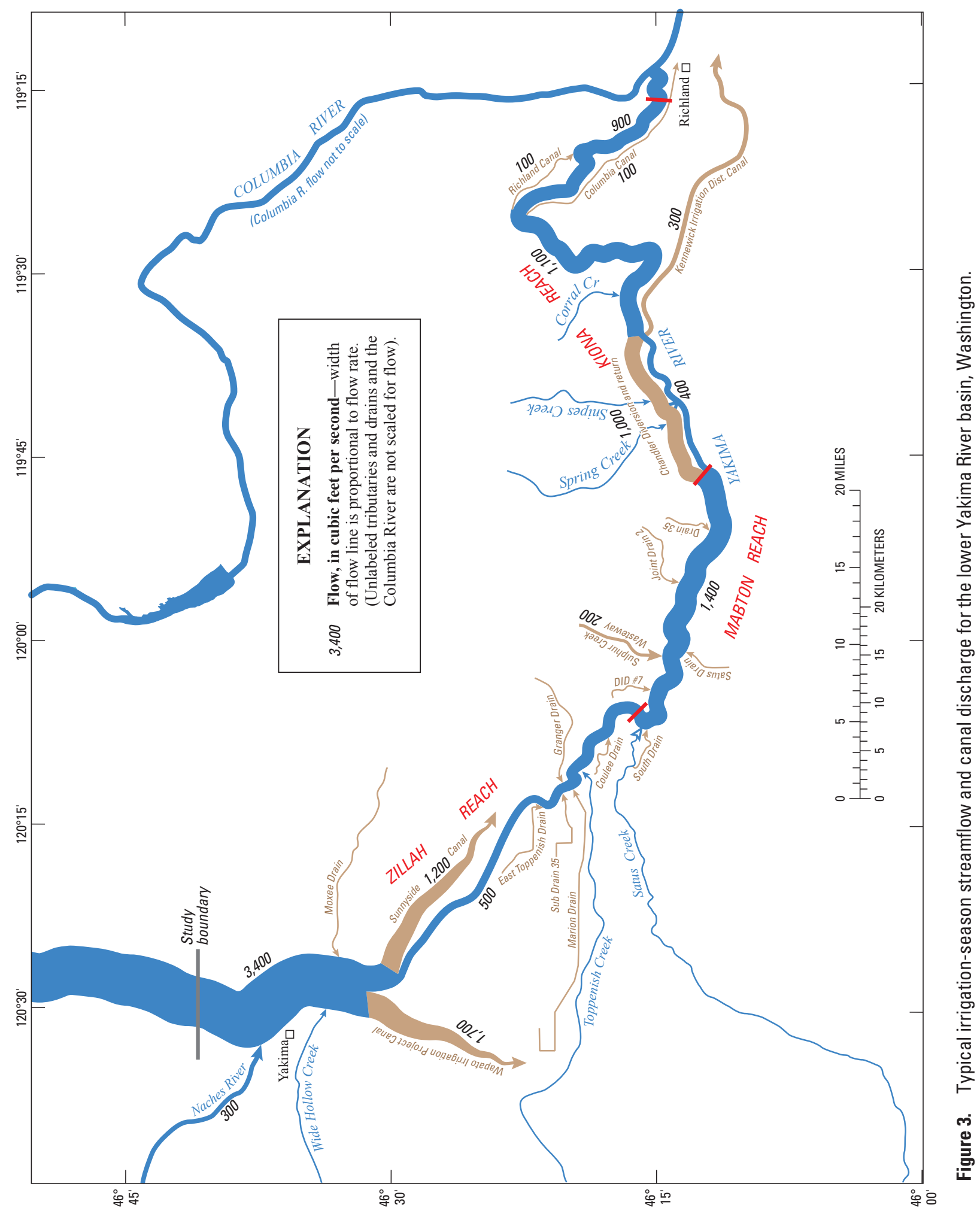




\section{Eutrophication}

One consequence related to the nutrient enrichment, or eutrophication, of streams is the increased growth of aquatic plants (algae and macrophytes) to levels that cause degraded water quality and interfere with uses such as fisheries, recreation, and agriculture. Possible secondary effects of the excessive growth of aquatic plants are low dissolved oxygen from respiration and high $\mathrm{pH}$ from photosynthesis that can negatively affect aquatic life. In addition, aquatic plants can provide habitat for opportunistic predators (for example, bass) that may prey on smaller salmonids.

\section{Nutrient Sources, Transport, and Cycling}

Although some nutrients enter the lower Yakima River directly from wastewater treatment plants, most nutrients come from diffuse sources such as atmospheric deposition, runoff and leaching from fertilizer application and animal waste, urban runoff, decay of vegetation, and septic system effluent. Nutrients from diffuse sources are delivered to the Yakima River through tributaries, irrigation return flows, overland runoff, and ground water (fig. 4).

The complex factors controlling the delivery of nutrients to the lower Yakima River operate at different time scales and are influenced by climate, land cover and land use

\section{Types of Aquatic Plants}

Algae are photosynthetic organisms that contain chlorophyll and are important components of stream ecosystems because they convert sunlight into energy and are the beginning of the food chain for many stream organisms. Stream algae include free-floating phytoplankton and attached algae. Periphytic algae (for example, diatoms, filamentous green algae, and blue-green algae), also called benthic algae, are attached to rocks, whereas epiphytic algae are attached to other aquatic plants. Because algae lack true stems, roots, and leaves, they must obtain nutrients directly from the surrounding water. Macrophytes are vascular aquatic plants (some species have roots and some do not) that can be an important part of aquatic ecosystems because they provide habitat and food for diverse aquatic organisms and increase ecosystem complexity (Bowden and others, 2006).

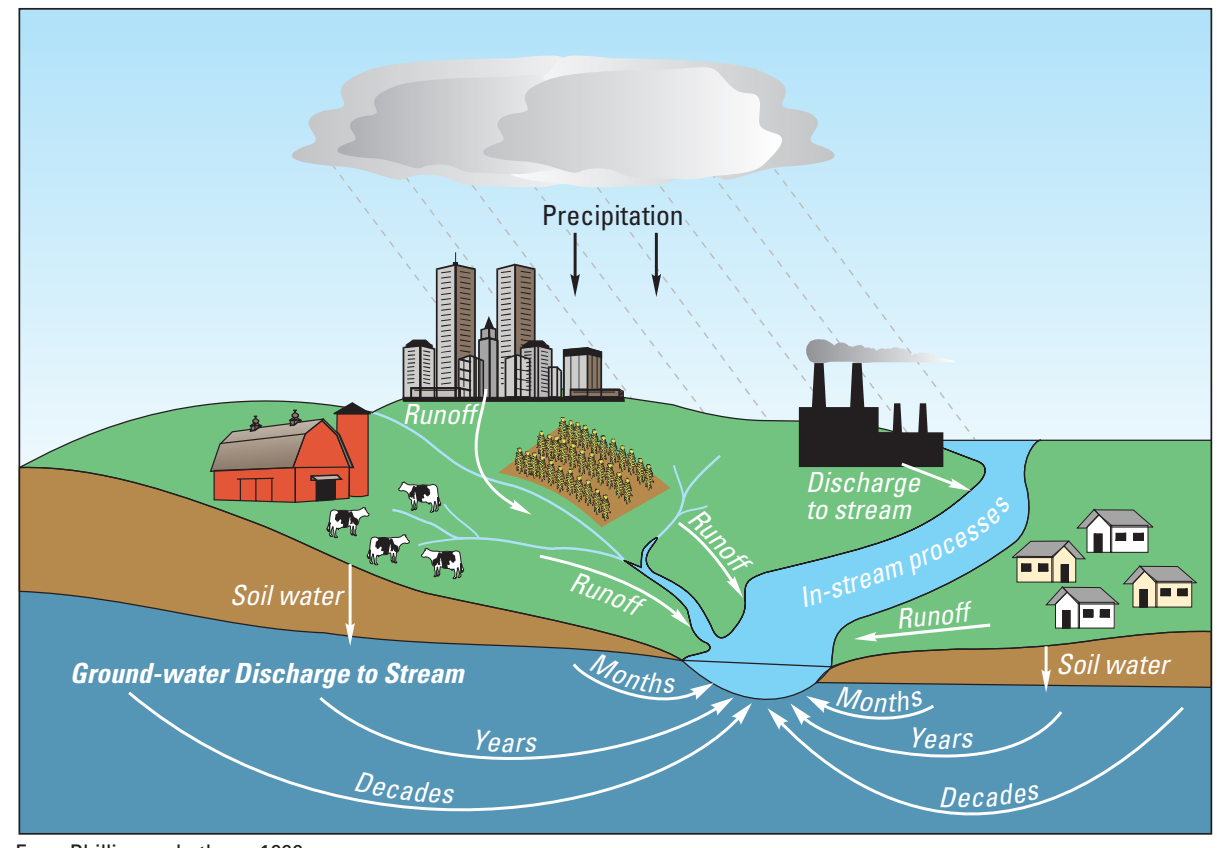

From Phillips and others, 1999

characteristics, and soil properties (Shepherd and others, 1999). Whereas nutrients from wastewater treatment plants are delivered immediately to the river and those from overland runoff are delivered to the river within hours or days of a precipitation event or irrigation application, the time required for nutrients to travel to the river through ground water ranges from months to decades. The transport and transformation of nutrients depend on a complex system of biotic and abiotic processes that include nitrogen fixation by bacteria, uptake and release by aquatic organisms, adsorption on soil particles, and deposition and entrainment (Webster and Swank, 1985).

Figure 4. Hypothetical water cycle showing potential pathways for nutrients to enter streams and rivers. 


\section{Factors Related to the Distribution and Abundance of Aquatic Plants}

\section{Algae}

The level of algal biomass depends on the physical, chemical, and biological characteristics of a stream, including water velocity, water temperature, light availability, and nutrient concentrations (Biggs and Close, 1989; Steinman, 1996). Hydrologic conditions also may affect algal biomass through physical scouring, especially during high flow events, and grazing by benthic invertebrates and herbivorous fish also can reduce algal biomass (Steinman, 1996). A summary of the potential factors affecting algal biomass given adequate nutrient concentrations and nontoxic conditions is shown in table 1.

\section{Macrophytes}

Light availability, rather than nutrient availability, is a common factor limiting macrophyte growth (Madsen and others, 2001) - turbidity levels, phytoplankton abundance, and water depth all affect light availability (Barko and others, 1986; U.S. Environmental Protection Agency, 2000a). Rooted

Table 1. Potential factors affecting algal biomass given adequate-to-high nutrient supply and nontoxic conditions.

[Table modified after U.S. Environmental Protection Agency, 2000a.Abbreviations: $\mathrm{ft} / \mathrm{s}$, foot per second; >, greater than; $<$, less than]

\begin{tabular}{|c|c|}
\hline \multicolumn{2}{|c|}{ Periphyton biomass } \\
\hline High & Low \\
\hline High current velocity $(>0.33 \mathrm{ft} / \mathrm{s})$ & Low current velocity $(<0.33 \mathrm{ft} / \mathrm{s})$ \\
\hline Low turbidity/color & High turbidity/color \\
\hline$\square$ Open canopy & Closed canopy \\
\hline Shallow stream depth & $\square$ Greater stream depth \\
\hline a Minimal scouring & $\square$ High scouring \\
\hline Limited macroinvertebrate grazing & $\square$ High macroinvertebrate grazing \\
\hline Gravel or larger substrata & Sand or smaller substrata \\
\hline Smaller depth to width ratio & \\
\hline \multicolumn{2}{|c|}{ Phytoplankton biomass } \\
\hline High & Low \\
\hline Low current velocity $(<0.33 \mathrm{ft} / \mathrm{s})$ & High current velocity $(>0.33 \mathrm{ft} / \mathrm{s})$ \\
\hline Long detention time (>10 days) & $\square$ Short detention time (<10 days) \\
\hline Low turbidity/color & High turbidity/color \\
\hline Open canopy & Closed canopy \\
\hline Greater stream depth & Shallow stream depth \\
\hline Greater depth to width ratio & \\
\hline
\end{tabular}

macrophytes obtain nitrogen and phosphorus either through roots in the bed sediment or through shoots in the water column, and macrophytes with extensive root systems are able to meet their nutrient needs predominantly from the bed sediment (Carignan, 1982; Chambers and Prepas, 1989; Barko and others, 1991).

\section{Previous Studies}

The Yakima River is generally well-studied compared to other moderately sized rivers in Washington State, but no detailed studies addressing eutrophication processes have been done. USGS studies of the Yakima River have documented the spatial and temporal variation in nitrogen and phosphorus (Morace and others, 1999), analyzed trends in the concentrations of nutrients and suspended sediment (Ebbert and others, 2003), and described the distribution of fish, benthic invertebrate, and algal communities (Cuffney and others, 1997). Regional and national studies that have included data collected in the Yakima River basin have analyzed the relation between nutrient concentrations and land use (Mueller and Spahr, 2006) and the trends in nutrient concentrations (Wise and others, 2007). The Washington State Department of Ecology (WA DOE) modeled the potential effect of relocating a major diversion point near RM 37, including changes in dissolved oxygen, $\mathrm{pH}$, and temperature (Carrol and Joy, 2002).

\section{Methods}

The first year of the study (2004) was used to qualitatively and semiquantitatively characterize the aquatic plant conditions, geomorphology, and habitat in the lower 116 mi of the Yakima River, characterize the nutrient and suspended-sediment conditions, calculate a load balance for nutrients and suspended sediment, and begin to characterize the extent and severity of exceedences of the State waterquality standards. This accomplished the first and second study objectives and began work on the third objective. The results from the first year of study were used to divide the river into three reaches based on aquatic plant growth, physical characteristics, and water-quality conditions - the Zillah reach from RM 116 to RM 72, the Mabton reach from RM 72 to RM 47, and the Kiona reach from RM 47 to RM 4.

During 2005-07, the aquatic plant conditions and the extent and severity of exceedences of the State water-quality standards in the three reaches were characterized in more detail (objective 3). The important factors related to the spatial and temporal patterns in aquatic plant and water-quality conditions (objective 4) were investigated by assessing each of the three reaches along with the lower Naches River, a major tributary that enters the Yakima River at RM 117. These targeted studies were done in representative sections of each 
reach and allowed us to quantify relations that might not have been apparent over the entire $116 \mathrm{mi}$ of the lower Yakima River. The Naches River was included in 2007 to provide a comparison between periphyton growth in the Zillah reach with a river of similar discharge, but with lower nutrient concentrations.

Because the study approach for each year was based on the findings of the preceding year, the overall study approach (appendix A) was adaptive (especially related to objective 4). Building on the results from each year allowed the flexibility to attempt to answer questions of the most interest to water-quality managers and other stakeholders as the study progressed.

\section{Data Collection}

Data collection included an assessment of aquatic plant conditions (qualitative species composition and quantitative biomass for algae and macrophytes), geomorphology, and habitat; water-quality sampling for total and dissolved nitrogen and phosphorus; and continuous monitoring of field parameters (water temperature, specific conductance, dissolved oxygen, $\mathrm{pH}$, turbidity, and total chlorophyll [Chl a]) (table 15; at back of report).

Data collection typically began each year in March and continued into October, and included the high flow springrunoff period and the relatively low flow summer and early autumn runoff period. Reach-scale surveys of aquatic plant growth were completed in the lower Yakima River during low flow periods in 2005, 2006, and 2007, when additional habitat data (water depth, velocity, and profiles of light penetration into the water column) also were collected.

\section{Assessment of Aquatic Plant Conditions, Geomorphology, and Habitat}

A survey for aquatic plant occurrence, geomorphology, and habitat (substrate type, water depth, and velocity) was done in the lower $116 \mathrm{mi}$ of the Yakima River June 14-18, 2004, during abnormally low streamflow. The mean daily streamflow in the Yakima River at Kiona was $1,190-1,850 \mathrm{ft}^{3} / \mathrm{s}$ during the assessment, which was well below the long-term mean of 5,238 $\mathrm{ft}^{3} / \mathrm{s}$ for June 14-18. Most of this assessment was done by boat or kayak, but a small section of the river was not navigable and was assessed by wading or from the river bank. All data collected during the June 2004 survey are available at http://or.water.usgs.gov/ projs_dir/yakima nutrients/ (U.S. Geological Survey, 2008). Measurements of water depth, velocity, and photosynthetically active radiation (to calculate light extinction coefficients) were made in 2005, 2006, and 2007 in support of targeted reachscale studies (table 15).

\section{Water Sample Collection and Laboratory Analyses}

A Lagrangian synoptic survey was performed during July 26-29, 2004, to investigate longitudinal water-quality conditions in the lower Yakima River. The synoptic sampling included 13 main stem sites on the Yakima River, the mouths of 15 tributaries, the outflow of 6 wastewater treatment plants that discharge directly to the Yakima River, 3 canal diversions, and 1 canal power plant return. The water-quality parameters measured included dissolved nitrite plus nitrate, dissolved ammonia, total Kjeldahl nitrogen (TKN), total phosphorus, dissolved orthophosphate, dissolved silica, suspended sediment, and Chl $a$. Streamflow and other flow values were obtained at all sampling locations (either directly by project personnel or from USGS or Bureau of Reclamation gaging stations) and field parameters (water temperature, $\mathrm{pH}$, dissolved oxygen, and specific conductance) were measured at most sites. Other water-quality surveys for nutrients were conducted in 2005-07 in support of targeted reach-scale studies and a small number of samples were collected in 2006 and 2007 from 10-cm deep piezometer wells inserted into the riverbed to collect pore water and measure nutrient concentrations and field parameters. Water samples were collected using USGS methods (USGS, variously dated). All surface-water samples were depth and width integrated, except for grab samples taken from the wastewater treatment plants and during some of the reach-scale studies.

All water-quality samples except suspended-sediment were analyzed at the Bureau of Reclamation Pacific Northwest Laboratory in Boise, Idaho. Suspended-sediment samples were analyzed at the USGS Cascade Volcano Observatory laboratory in Vancouver, Washington. The results from all water-quality measurements made during this study are available online through the USGS National Water Information System (http://pubs.usgs.gov/fs/FS-027-98/) (U.S. Geological Survey, 1998) and the Washington State Department of Ecology (WADOE) Environmental Information Management System (http://www.ecy.wa.gov/eim/) (Washington State Department of Ecology, 2007).

\section{Algal Biomass Measurements}

Algal assemblages were evaluated qualitatively (presence/absence for general taxonomic categories) on select field trips and longitudinal surveys conducted during 2005-07, and quantitative samples were collected for periphyton biomass (Chl $a$ and ash-free dry mass, AFDM) in 2006 and 2007 between RM 103 and 87 in the lower Yakima River, and below RM 12 in the Naches River. Epiphytic algae attached to rooted or floating macrophytes were observed - the abundance of this type of algae was not quantified, but was noted in field observations. Water samples also were collected intermittently 
in the Yakima River and analyzed for $\mathrm{Chl} a$, an estimate of the amount of algae in the water column, at the continuous monitor locations for quality-assurance purposes.

Periphyton biomass samples were collected on 13 occasions during the 2005-07 growing season from wadeable habitats that supported algal growth - rock or cobble substrates in shallow riffles and runs. For partially wadeable sites, rocks were collected from stream margins in areas of flowing water. Periphyton biomass samples were collected from the tops of river cobbles in relatively shallow $(\sim 0.5-3 \mathrm{ft})$ depths in mostly laminar habitats. To randomize rock selection, washers with short lengths of orange flagging were hand-tossed from shore to 5-10 locations within the sampling zone, and the rock or cobble immediately upstream of the washer was carefully removed and brought to the bank where algal material was collected using the top-rock/cylinder scrape method (Moulton and others, 2002).

Processing of periphyton biomass samples occurred offsite by homogenizing in an electric blender and subsampling small volumes of the algal slurry, typically 5-10 mL. Subsamples for algal biomass were removed from the blender using a large-orifice pipette and transferred onto 47-mm glass fiber filters $(\mathrm{GF} / \mathrm{F})$ under vacuum pressure using a plastic filtration apparatus. Chl $a$ and AFDM were analyzed at the Bureau of Reclamation Laboratory in Boise, Idaho. Chl $a$ was analyzed spectrophotometrically with acid correction, and AFDM (ash-free dry mass) was analyzed gravimetrically using standard methods (American Public Health Association, 1989).

\section{Macrophyte Biomass Measurements}

Macrophyte biomass samples were collected in late August and early September in 2-mi sections of the Zillah, Mabton and Kiona reaches in 2005, and in the Kiona reach in 2006 and 2007 at approximately the same locations that were sampled in 2005. Macrophyte samples were collected from six transects randomly selected within each reach section by wading in the shallows or with SCUBA divers. Samples were collected at five roughly equally spaced points across each transect. To avoid sampler bias, a weighted marker with a float was thrown from a small raft to each point to mark each sampling location. Quadrat sampling areas ranged from 0.08 to $0.19 \mathrm{~m}^{2}$ per sample. Plants were identified to species, stripped of their roots (if present), and placed in labeled plastic bags. Plants were further processed offsite: they were rinsed with tap water to remove debris (sediment and attached algae), placed outside and air dried for 3-9 days, turning about every other day, and dried in an forced-air oven for 2-6 days at $70^{\circ} \mathrm{C}$. Samples were weighed to the nearest $0.1 \mathrm{~g}$. In 2005, 12 dried plant tissue samples were shipped to Soiltest Farm Consultants, Inc. in Moses Lake, Washington, for total nitrogen, total phosphorus, and total carbon analyses. The samples analyzed for nutrient and carbon content included the stems and leaves and consisted of either the total amount of plant sample from a particular quadrat (for small sample sizes) or a subsample (for the larger sample sizes) from a particular quadrant. To subsample, the entire sample was crushed into relatively small particles, well-mixed, then several small portions were withdrawn by hand. All macrophyte biomass results are available at http://or.water.usgs.gov/projs_dir/ yakima_nutrients/(U.S. Geological Survey, 2008).

\section{Streamflow}

Data from USGS and Bureau of Reclamation (Bureau of Reclamation, 2006) streamflow gaging stations are used in this report (table 15). Additional instantaneous streamflow measurements were made according to standard USGS protocols (U.S. Geological Survey, variously dated).

\section{Continuous Monitoring of Field Parameters}

Continuous field parameter data were collected at 15- or 30- minute intervals for water temperature, specific conductance, dissolved oxygen, $\mathrm{pH}, \mathrm{Chl} a$, and turbidity using YSI 6600 multiparameter sondes (YSI, 2008). The operation of continuous monitors is described by Wagner and others (2006).

A continuous water-quality monitor was installed in the Yakima River at Kiona (RM 30) from April 20, 2004 to September 28, 2007, in the Yakima River near Zillah (RM 87) from March 1 to October 13, 2005, and from March 7 to October 3, 2006, and in the Yakima River near Mabton (RM 55) from February 28 to November 3, 2005. Chl $a$ was measured during the monitor deployment at Kiona until early April 2006 and at Mabton and Zillah during the entire monitor deployments in 2005.

Continuous water-quality monitors were installed for short periods (5-14 days) in nine reaches in the lower Yakima River and one reach of the lower Naches River during 2004 (fig. 2). These monitor deployments were used to assess spatial and seasonal variations in river conditions during 2004 within river reaches that were thought to be distinct from each other based on geomorphology, streamflow, and nutrient loading (Stuart McKenzie, U.S. Geological Survey (ret.), oral commun., 2003). Monitor deployments were repeated from two to five times at each site from March through October in 2004.

Short-term continuous water-quality monitors also were installed during the entire months of July and August in the Kiona reach in 2005 and 2007 and in the Zillah in 2005 as part of two-station productivity experiments. Short-term continuous water-quality monitors also were installed for 14-day periods during July-September in the Zillah reach in 2006 and 2007 and in the Naches River in 2007 in support of 
periphytometer experiments and to assess longitudinal patterns in water quality. Continuous water-quality data were not obtained during some of the periphytometer deployments due to malfunctions with monitoring equipment.

An optical dissolved oxygen probe (YSI model 6150) was installed on the Kiona monitor in July 2006, which produced two sets of dissolved oxygen data until February 2007, when the Clark cell type dissolved oxygen probe (YSI model 6562) was removed. Continuous measurement of watercolumn turbidity (the cloudiness or opacity of a liquid which is measured by analyzing the light-absorbing and light-scattering properties) was obtained with an infrared light probe (YSI model 6136), which reports turbidity in terms of Formazin Nephelometric Units (FNU). Continuous measurements of water-column total chlorophyll were obtained with an optical fluorescence probe (YSI model 6025) that measures chlorphyll fluorescence at wavelengths from 630-700 nanometers and were calibrated to a standard solution of acridine orange. The total chlorophyll data from the probe provided a nearcontinuous estimate of the amount of algal material in the water column during monitor deployments.

The continuous field parameter data from this study (unit and daily values) can be obtained by accessing the USGS Data Grapher web page (http://or.water.usgs.gov/cgi-bin/ grapher/graph setup.pl) (U.S. Geological Survey, 2002). Daily summaries of the continuous field parameter data also are available through the USGS National Water Information System (http://waterdata.usgs.gov/nwis/) (U.S. Geological Survey, 1998) and WADOE Environmental Information Management System (http://www.ecy.wa.gov/eim/)

(Washington Department of Ecology, 2007).

\section{Periphytometer Experiments}

The primary productivity of periphyton was assessed through the use of nutrient-diffusing substrate (NDS) periphytometers. These devices measure the accrual rate of periphyton (as Chl $a$ in milligrams per square meter per day) while delivering bioavailable forms of nitrogen $(\mathrm{N})$ and phosphorus (P). Nutrients were added alone or in combination to test for single nutrient limitation or co-limitation compared to controls with no nutrient additions. NDS periphytometers also were used to estimate periphyton community growth rates along a single limiting-nutrient enrichment gradient. As part of the investigation of how nutrients influence the primary productivity of periphyton, an experimental nutrient enrichment gradient was established using liquid-liquid NDS periphytometers (Matlock and others, 1998). Periphytometers were installed in 2006 at four sites in the Zillah reach at RM 103, 92, 89 and 87, and in 2007 at RM 103 and 87, at RM 12.2, 3.5 and 2.8 in the lower Naches River, and at one downstream site on the Yakima River at Kiona (table 15).

In all cases, periphytometers were modified from a design developed by Matlock and others (1998). These Micro-NDS periphytometers have reduced reservoir volume and reduced exposed filter area compared to the original design (see McFarland and others, 2004, and Rodriguez and Matlock, 2008 for design details). Unlike the Matlock design, the Micro-NDS periphytometers were installed at the bottom of the water column directly on the substrate and anchored into place using two torpedo-shaped weights. Filters were covered with $0.5-\mathrm{mm}$ neutral density fiberglass screens to reduce grazing by fish and benthic invertebrates. During the periphytometer deployment at RM 87 in August and September 2007, however, an unscreened periphytometer also was installed to measure any difference in results between screened and unscreened experiments.

Three nutrient treatments plus a control were used at each periphytometer deployment site in the Yakima and Naches Rivers. The treatments and the number of replicates were balanced at each site, but not between sites. All nutrient additions were at a single level with five or more replicates per treatment. Nutrient media additions of $3 \mathrm{mg} / \mathrm{L} \mathrm{NO}_{3}-\mathrm{N}$ and $1 \mathrm{mg} / \mathrm{L} \mathrm{PO}_{4}-\mathrm{P}$ provided 350 micromolar $(\mu \mathrm{M}) \mathrm{N}$ and $100 \mu \mathrm{M}$ $\mathrm{P}$ solutions in the Micro-NDS media reservoirs. After the periphytometers were installed, nutrients were delivered to the filter substrate by diffusion during instream incubation. Filters were retrieved after 14 days and frozen until analysis (within 28 days of retrieval). Algal biomass production was measured as Chl $a$ accumulation on the glass-fiber filter substrates over the 14-day period. Nutrient treatments were compared to the ambient controls to test for nutrient limitation.

\section{Data Analysis}

\section{Comparison of Results to Water-Quality Reference Criteria and Standards}

Measurements of nutrient concentrations, algal biomass, and field parameters made during this study were compared to applicable reference conditions, nuisance conditions, and standards.

\section{Criteria for Nutrients and Algal Biomass}

The State of Washington has not established standards for nutrients and algal biomass. The U.S. Environmental Protection Agency (USEPA), however, has published suggested reference conditions on a regional scale to protect water bodies from the negative effects of nutrient enrichment, including excessive algal growth. The reference conditions are not water-quality standards, but are intended to be starting points for States and Tribes to use for setting their own regional nutrient criteria. The lower Yakima River basin is in the USEPA Nutrient Ecoregion III (Xeric West), subgroup 10 (Columbia Plateau) (U.S. Environmental Protection Agency, 2000b). Suggested nutrient reference conditions for Yakima River basin streams in the Xeric West Ecoregion are given in table 2. The suggested reference conditions for streams in the 
Table 2. Reference conditions for nutrients suggested by the U.S. Environmental Protection Agency for streams in the Yakima River basin, Washington.

[Data from U.S. Environmental Protection Agency, 2000b. Values in milligrams per liter]

\begin{tabular}{lcc}
\hline \multicolumn{1}{c}{ Parameter } & $\begin{array}{c}\text { Number of } \\
\text { streams }\end{array}$ & $\begin{array}{c}\text { Suggested reference } \\
\text { condition }\end{array}$ \\
\hline Total Kjeldahl nitrogen & 106 & 0.288 \\
Nitrite plus nitrate & 71 & 0.072 \\
Total nitrogen & 24 & 0.221 \\
Total phosphorus & 127 & 0.03 \\
\hline
\end{tabular}

Yakima River basin were based on the $25^{\text {th }}$ percentile of the lowest nutrient concentrations, representing the least impacted conditions and intended to be protective of designated uses (U.S. Environmental Protection Agency, 2000b).

Although the USEPA also has published suggested algal reference conditions for the Yakima River basin (U.S. Environmental Protection Agency, 2000b), these values were based on a small number of samples that may not have been representative of reference conditions in the basin. Numerous studies have published recommended ranges or limits to describe periphyton biomass levels indicative of nuisance conditions (Horner and others, 1983; Welch and others, 1988; Welch and others, 1989; Biggs, 1996; Dodds and others, 1997; Dodds and others, 1998). Many benchmarks were developed to protect recreational or aesthetic qualities of streams and rivers, and (or) to protect aquatic life from unhealthy conditions that result from excessive algal growths such as low dissolved oxygen concentrations, high $\mathrm{pH}$, and affects on salmon spawning beds. A generally accepted nuisance threshold for periphyton biomass is between 100 and $150 \mathrm{mg} / \mathrm{m}^{2}$ for Chl $a$. The government of British Columbia, Canada, established a Chl $a$ density of $100 \mathrm{mg} / \mathrm{m}^{2}$ as indicative of nuisance growth for periphyton in streams (British Columbia Ministry of Environment, 2008). This value was used to compare samples collected during this study. The State of Washington currently does not use phytoplankton biomass as a tool for assessing stream health. The State of Oregon, however, has established a $\mathrm{Chl} a$ concentration of $15 \mu \mathrm{g} / \mathrm{L}$ as indicative of nuisance growth for phytoplankton in streams (Oregon Administrative Code, 2006). This value was used to compare samples collected during this study.

\section{Standards for Temperature, Dissolved Oxygen, and pH}

Water temperature, dissolved oxygen, and $\mathrm{pH}$ conditions were compared to the Washington State standards and described using the percentage of days and the percentage of time when exceedences occurred during a particular period.
The former was calculated by dividing the number of days with at least one exceedence of the Washington State standard by the total number of days when measurements were made (only days with 24 hours of monitoring were included) and the latter was calculated by dividing the number of readings exceeding the Washington State standard by the total number of readings.

The State of Washington has established standards for water temperature, dissolved oxygen, and $\mathrm{pH}$ for the lower Yakima River (Washington Administrative Code, 2006). Water temperature shall not exceed $21^{\circ} \mathrm{C}$ due to human activities except when natural conditions exceed $21^{\circ} \mathrm{C}$, in which case no temperature increase is allowed that will raise the receiving water temperature by more than $0.3^{\circ} \mathrm{C}$. Under the Washington State water-quality standards, the lower Yakima River is in the category of salmonid spawning, rearing, and migration habitat. Based on this designation, the water-quality standards specify a lowest 1-day minimum dissolved oxygen concentration of $8.0 \mathrm{mg} / \mathrm{L}$ and that the $\mathrm{pH}$ shall be within the range of 6.5 to 8.5 units with a human-caused variation within this range of less than $0.5 \mathrm{pH}$ units.

Although continuous monitoring data were collected throughout the year at one station (Kiona), most of the descriptions and analyses in this report are limited to the irrigation season results (March 1 through September 30 ) because this was the period when the effects from eutrophication were most severe. The differences in the severity of water-quality conditions between the Zillah, Mabton, and Kiona reaches and between years was evaluated by comparing the mean daily maximum water temperature and $\mathrm{pH}$ readings and mean daily minimum dissolved oxygen concentrations between July 1 and August 31, the period with the highest water temperature and $\mathrm{pH}$ values and lowest dissolved oxygen concentrations.

\section{Redfield Ratio}

Redfield ratios were used to characterize the nutrient status of the Zillah reach regarding algal growth. The Redfield ratio is calculated using the dissolved inorganic (bioavailable) forms of $\mathrm{N}$ (dissolved nitrite plus nitrate and dissolved ammonia, or DIN) and P (soluble reactive phosphorus, or SRP). The ratio of DIN to SRP indicates the relative availability of the two primary nutrients that aquatic plants require for growth. During algal growth, about 16 atoms of $\mathrm{N}$ are used for every atom of $\mathrm{P}-7: 1$ by weight, which is the Redfield ratio. The Redfield ratio does not apply to the growth of macrophytes, which are able to obtain nutrients from their roots and tend to have much higher $\mathrm{N}: \mathrm{P}$ ratios than algae. Fernandez-Alaez and others (1999) determined that the N:P ratios for 12 lake macrophytes ranged from 13 to 121 , with a mean of 35 . 


\section{Estimates of Gross Primary Productivity}

One objective of this study

was to assess the relations among physical parameters and aquatic plant characteristics - especially whole stream gross primary productivity (GPP), because GPP is a measure of the growth rate of plants in a stream. The diel (24-hour) oxygen curve method for estimating GPP (Odum, 1956), which has been used frequently to evaluate the productivity of stream ecosystems (Izagirre and others, 2008), was evaluated as a tool that might be used by environmental managers to assess the conditions of the Yakima River with regard to the rate of plant growth. This method for estimating GPP was evaluated for two applications: (1) as an estimate of the rate of plant growth instead of direct biomass measurements and (2) as a way to assess the processes and factors related to the rate of aquatic plant growth.

The diel dissolved oxygen curve method calculates GPP (in grams of $\mathrm{O}_{2}$ produced per square meter per day) by using the daily change in dissolved oxygen concentration measured by continuous monitoring at one or two monitoring stations, an estimate of the rate of oxygen transfer between the water and the atmosphere, and the depth of the stream. The onestation method is acceptable if the metabolic characteristics of the water flowing into and out of a study reach are similar. Otherwise, the two-station method is recommended (Britton and Greeson, 1989). The one-station method was used in this study to show seasonal and year-to-year differences in GPP. The two-station method was used, however, in some instances as a check on the suitability of the one-station method.

The continuous monitoring of dissolved oxygen and water temperature and the availability of nearby daily gaging station records provided a rich data set for estimating GPP. The GPP estimates were determined using a spreadsheet developed at the Central Plains Center for Bioassessment at the University of Kansas that incorporates the methods proposed by Odum (1956) (Anderson and Huggins, 2003). GPP was estimated at 3-day intervals for two periods during

\section{Primary Productivity}

Primary productivity is the "rate of formation of organic matter from inorganic carbon by photosynthesizing organisms and thus represents the conversion of solar energy to reduced chemical energy" (Bott, 2006). The stoichiometric relation between inorganic carbon (in the form of $\mathrm{CO}_{2}$ ) and cellular production is given by the equation: $6 \mathrm{CO}_{2}+6 \mathrm{H}_{2} \mathrm{O} \longrightarrow \mathrm{C}_{6} \mathrm{H}_{12} \mathrm{O}_{6}+6 \mathrm{O}_{2}$. Primary productivity can be estimated by measuring the amount of organic matter formation (the $\mathrm{C}_{6} \mathrm{H}_{12} \mathrm{O}_{6}$ term) - the accrual rate of plant biomass, or by measuring the amount of oxygen production (the $\mathrm{O}_{2}$ term). Gross primary productivity (GPP) is the rate at which autotrophic organisms convert and store solar energy as biomass. Some energy stored through primary productivity is lost through plant respiration. The community metabolism of a stream includes the GPP of the plants and the community respiration (respiration by autotrophic and heterotrophic organisms). Autotrophic organisms (generally plants and some bacteria) do not depend on other organisms for energy, whereas heterotrophic organisms (animals and most bacteria) subsist on organic matter provided by other organisms. The net primary productivity of a stream is the difference between the GPP and the community respiration.

the growing season. The first period was spring (defined as March 1 through June 30), when the conditions in the river (streamflow, turbidity, temperature) are most variable (within this period and between years) and when the macrophytes start to grow. The second period was summer (defined as July 1 through August 31), when streamflow is relatively consistent between years and when the macrophytes have achieved their maximum biomass. The GPP analysis was limited to 2005 through 2007 because the 2004 water-quality record was incomplete and conditions during these 3 years were representative of the variability in macrophyte abundance during the study. One-station estimates of GPP were made at Kiona during March 1-August 30, 2005-07, and at Zillah during July 1-August 30, 2005. Two-station estimates of GPP were made at Kiona during July 19-September 26, 2005, July 7-13, 2007, and August 6-12, 2007, and at Zillah during July 22-August 30, 2005. For the two-station GPP estimates a second monitor was installed 2.0 and 1.5 mi upstream of the Kiona and Zillah monitors, respectively. 
Appropriate reaeration coefficient equations from the literature were used instead of experimentally derived values and were selected based on streamflow conditions (Anderson and Huggins, 2003). The mean reach-scale values for velocity and depth were needed for each day a GPP estimate was made. These values were obtained by measuring the water depth and water velocity longitudinally and horizontally along each study reach and scaling the measured values to reflect changes in streamflow. These measurements were made during July 2005 in the Kiona and Zillah reaches and repeated in July 2007 in the Kiona reach. A detailed description of the data collection and limitations with regards to the reaeration estimates is contained in appendix B.

\section{Maximum Depth of Plant Colonization}

Photosynthetically active radiation (PAR) data were used to calculate the maximum depth of macrophyte colonization (or compensation depth), $Z c$, measured in meters, using the following equation, which was derived from Beer's Law:

$$
Z c=2.99 / \mathrm{Kd},
$$

where

$Z c$ is the light extinction coefficient (a measure of the absorbance of PAR by the water column) and,

2.99 is the natural $\log$ of 0.05 , which assumes macrophytes need at least 5 percent of surface light to colonize at depth (Carter and Rybicki, 1990).

The estimated values for maximum depth of plant colonization (based on the light attenuation data for all three reaches of the lower Yakima River and the Naches River during 2005-07) were compared to concurrent turbidity readings to determine whether turbidity could be used to predict the maximum depths of plant colonization in the river.

\section{Statistical Comparisons Between Data Sets}

The two-sample t-test was used to compare the mean values for two data sets that were normally distributed. A standard ANOVA was used to compare the mean values for multiple data sets that were normally distributed, and Tukey's procedure was used to determine whether the 95 percent confidence intervals (based on the pooled standard deviation) for the mean values of any of the data sets overlapped. The Kruskall-Wallis rank test was used to compare the median values for multiple data sets that were not normally distributed, and the Wilcoxon signed rank test was used to determine whether the 95 percent confidence intervals for the median values of any of the data sets overlapped (Walpole and others, 2007). The relations between data sets were evaluated using linear and nonlinear regressions. The strength of a relation was evaluated using the $r^{2}$ value and a $p$-value $\leq 0.05$ was used to indicate whether a relation was significant.

The algal accrual rates measured during the periphytometer experiments were log-transformed to preserve homogeneity of variances and to allow for straightforward comparisons between geometric means (the nth root of the product of $n$ values) for all sites and treatments. Logtransformed data were analyzed using a full factorial ANOVA that tested for site by treatment interactions. Each treatment was at a single level and was compared to the no-addition control at each site. For this report, data from each periphytometer deployment were analyzed by river and by year.

\section{Data Quality Control}

Quality control (QC) samples comprised about 15 percent of all discrete samples, and consisted of field blank samples to check for potential contamination during collection, processing, and (or) laboratory analysis; replicate water samples to measure variability and analytical precision; and split samples to measure bias during processing and analysis. The results from the QC analysis for the discrete water-quality sampling are provided in appendix $\mathrm{C}$.

The QC activities for the continuous monitoring of field parameters were generally done in accordance with USGS guidelines (Wagner and others, 2006). Calibration and fouling corrections were calculated and applied to almost all the data - exceptions were the short-term monitor deployments from April through June 2004 and some periods in 2004 during the Kiona monitor deployment. Although the data quality control for many of the 2004 short-term monitor deployments did not follow the specifications in the USGS guidelines, problems caused by calibration drift were minimized because the calibrations were checked at the beginning of each monitor deployment and because of the short-term nature of the monitor deployments. Problems 
due to sensor fouling during the 2004 short-term monitor deployments were minimized because the monitors were routinely cleaned and serviced. The specifications in the USGS guidelines were followed for all 2004 monitor deployments after July 1 and all monitor deployments in 2005-07. The results from the QC activities for the continuous monitoring are provided in appendix D.

Quality assurance of the fluorometric total chlorophyll data collected at each of the continuous monitors included frequent calibrations with standard solutions of acridine orange, and comparisons with $\mathrm{Chl} a$ values obtained from traditional laboratory analyses of whole-water grab samples. When aggregated together, the probe measurements and laboratory data collected at all Yakima River monitor deployments were not significantly correlated. The results from the Zillah water-quality monitor, however, showed good agreement with the eight concurrent water samples $\left(r^{2}=0.80\right.$, $p<0.001$, with a ratio of 1.5 between the laboratory results and the probe), providing some degree of confidence in the total chlorophyll data from this continuous monitor. Total chlorophyll data from the other continuous monitors also were useful at times for explaining the general patterns observed in other water-quality parameters. No corrections were applied to the continuous total chlorophyll data to adjust for variations from the laboratory $\mathrm{Chl} a$ results.

Most ambient monitoring programs in the Yakima River basin use turbidity meters, which measure turbidity in NTU. Because suspended particles scatter light of different wavelengths with varying efficiency, FNU data often are not directly comparable to NTU data. Turbidity was measured intermittently during this study at the continuous monitoring sites using a turbidity meter that read in NTU. The ratio between the values measured in NTU and the concurrent values measured in FNU was equal to 0.95 when the linear relation between the two values was fixed at zero. Some readings in 2004 and 2005 were less than $0 \mathrm{FNU}$, which was probably due to improper calibration of the probe.

\section{Results}

\section{Hydrologic Conditions During 2004-07}

Spring runoff in the lower Yakima River was notably low during 2004, and exceptionally low during 2005 compared to historical conditions (ig. 5) because of below-average snowpack in the Cascade Range during these years. Compared

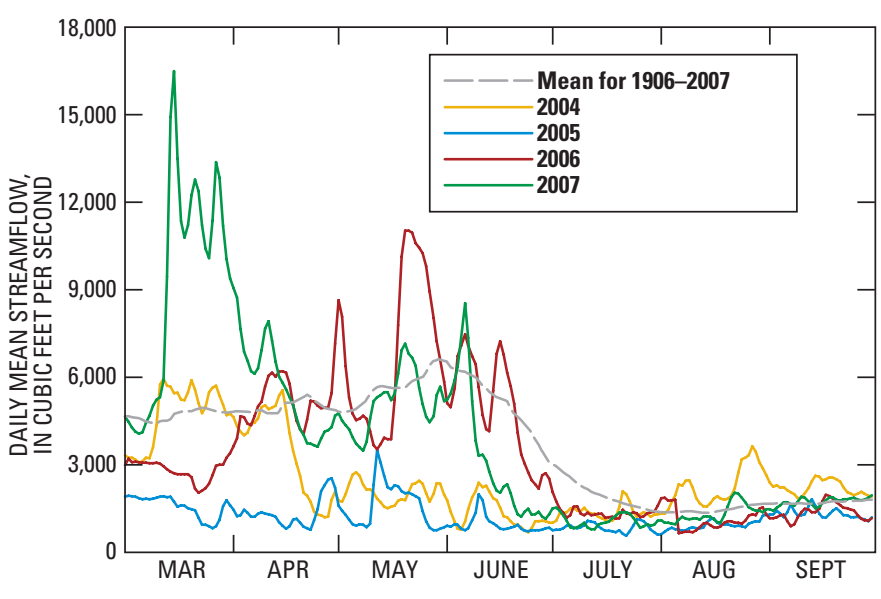

Figure 5. Daily mean streamflow for Yakima River at Kiona, Washington, March 1-September 30, 1906-2007 and 2004-07.

with the long-term (1906-2007) mean that contained 84 years of record, daily streamflows for March 1 through June 30 in 2004, 2005, 2006, and 2007 were 57, 27, 98, and 113 percent of mean, respectively, and for July 1 through September 30 were $113,60,74$, and 80 percent of mean, respectively.

\section{Reach Delineation According to Aquatic Plant Conditions, Geomorphology, and Habitat}

The results from the June 2004 longitudinal assessment (fig. 6; table 3) were used to delineate three distinct reaches of the lower Yakima River based on geomorphology and habitat, hydrology, and aquatic plant conditions (table 4). The Zillah reach (a combination of pools and runs, with abundant periphyton growth and sparse macrophyte growth) extended from the upstream edge of the study area at RM 116 to RM 72 upstream of Satus Creek. The Mabton reach (comprising two long pools, with sparse periphyton and macrophyte growth) extended from RM 72 to Prosser Dam (RM 47). The Kiona reach (comprising mostly runs, with abundant macrophyte and epiphytic algae growth) extended from RM 47 to RM 4 where the river is influenced by backwater from the Columbia River. 

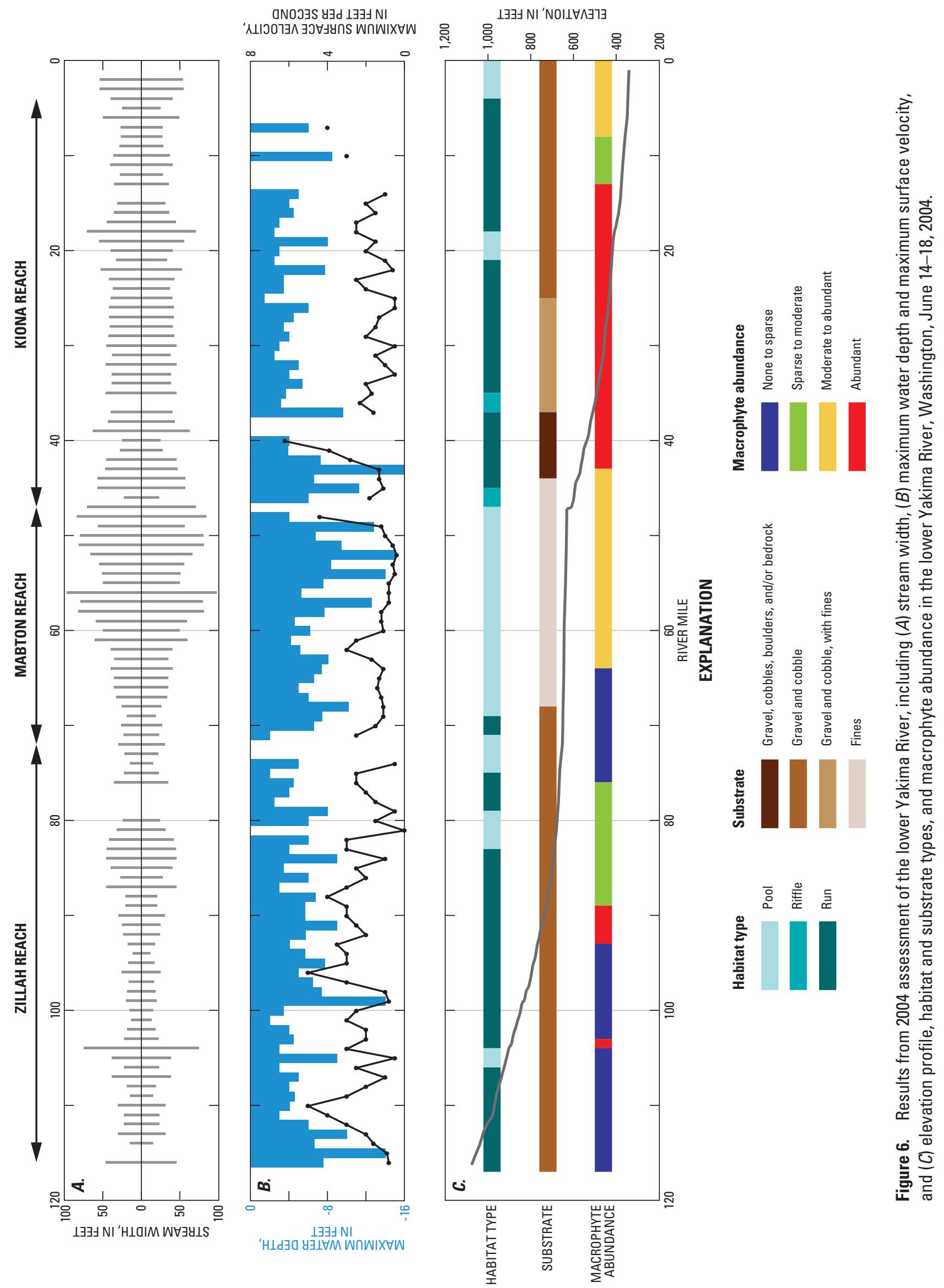

'HId $\exists$ Y Y $\exists \perp \forall M$ WNWIX 


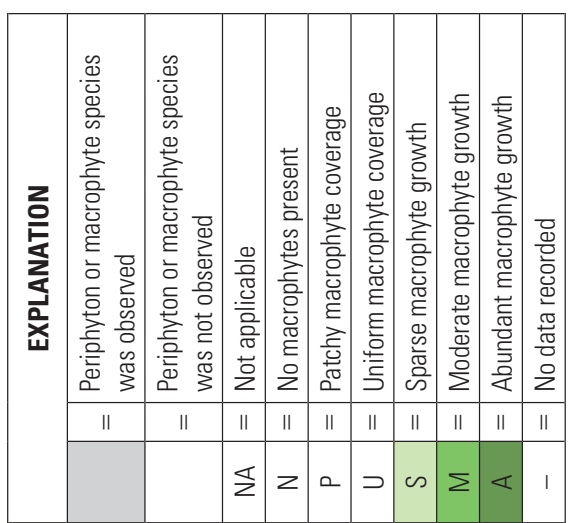

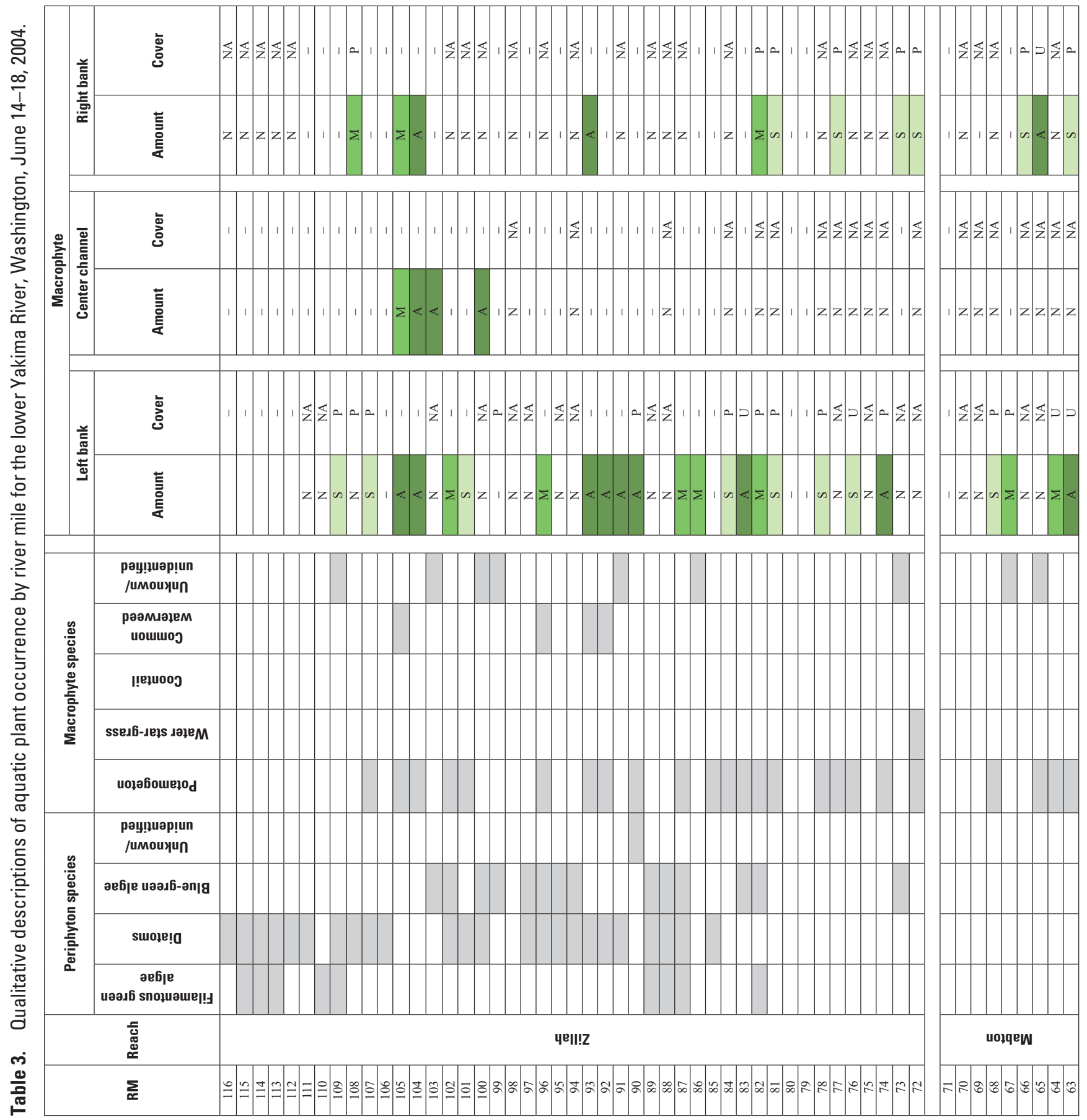



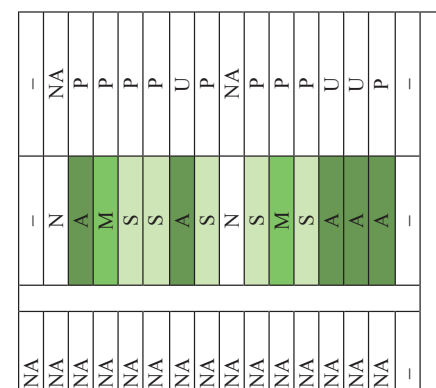

$z=z|z| z|z| z|z| z|z| z|z| z|z| z \mid$

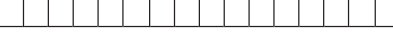

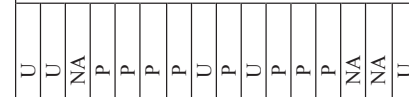
$\Sigma \Sigma z \Sigma \Sigma \Sigma \Sigma(<<<z \Sigma \Sigma n z z$

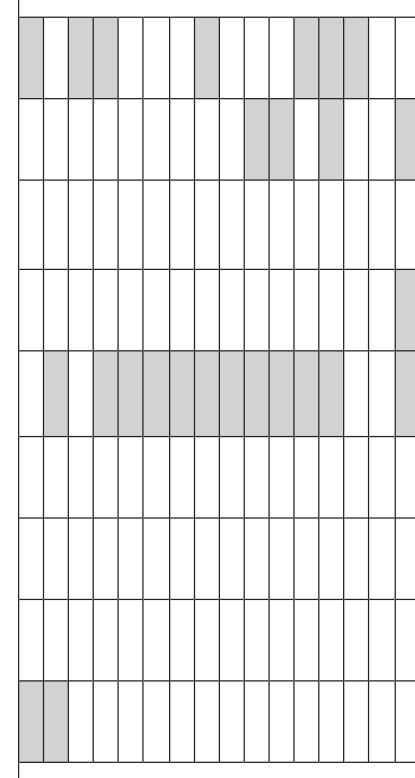

penu!̣uoj—uołqew

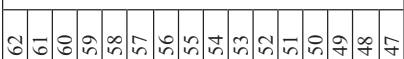

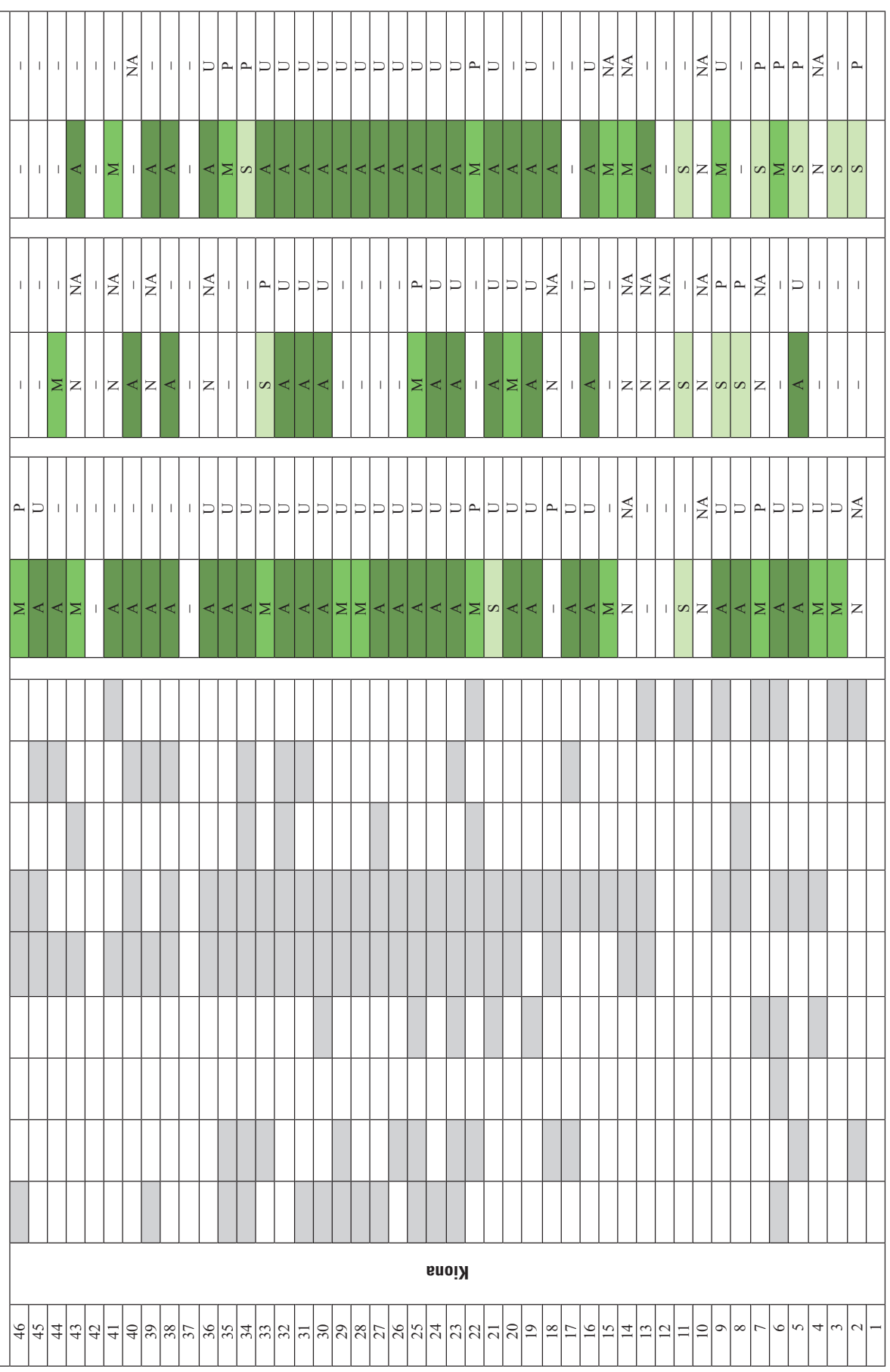


Table 4. Description of geomorphology and habitat, irrigation diversions, tributary and agricultural returns, light availability, aquatic plant growth, and nutrient concentrations in three reaches of the lower Yakima River, Washington, $2004-07$.

[Abbreviations: RM, river mile; $\mathrm{ft}$, foot; $\mathrm{ft} / \mathrm{s}$, foot per second; $\mathrm{ft} / 100 \mathrm{ft}$, foot per $100 \mathrm{feet} ; \mu \mathrm{g} / \mathrm{L}$, microgram per liter; $\mathrm{mg} / \mathrm{L}$, milligram per liter; $\mathrm{g} / \mathrm{m}^{2}$, gram per square meter; na, not applicable; -, no data]

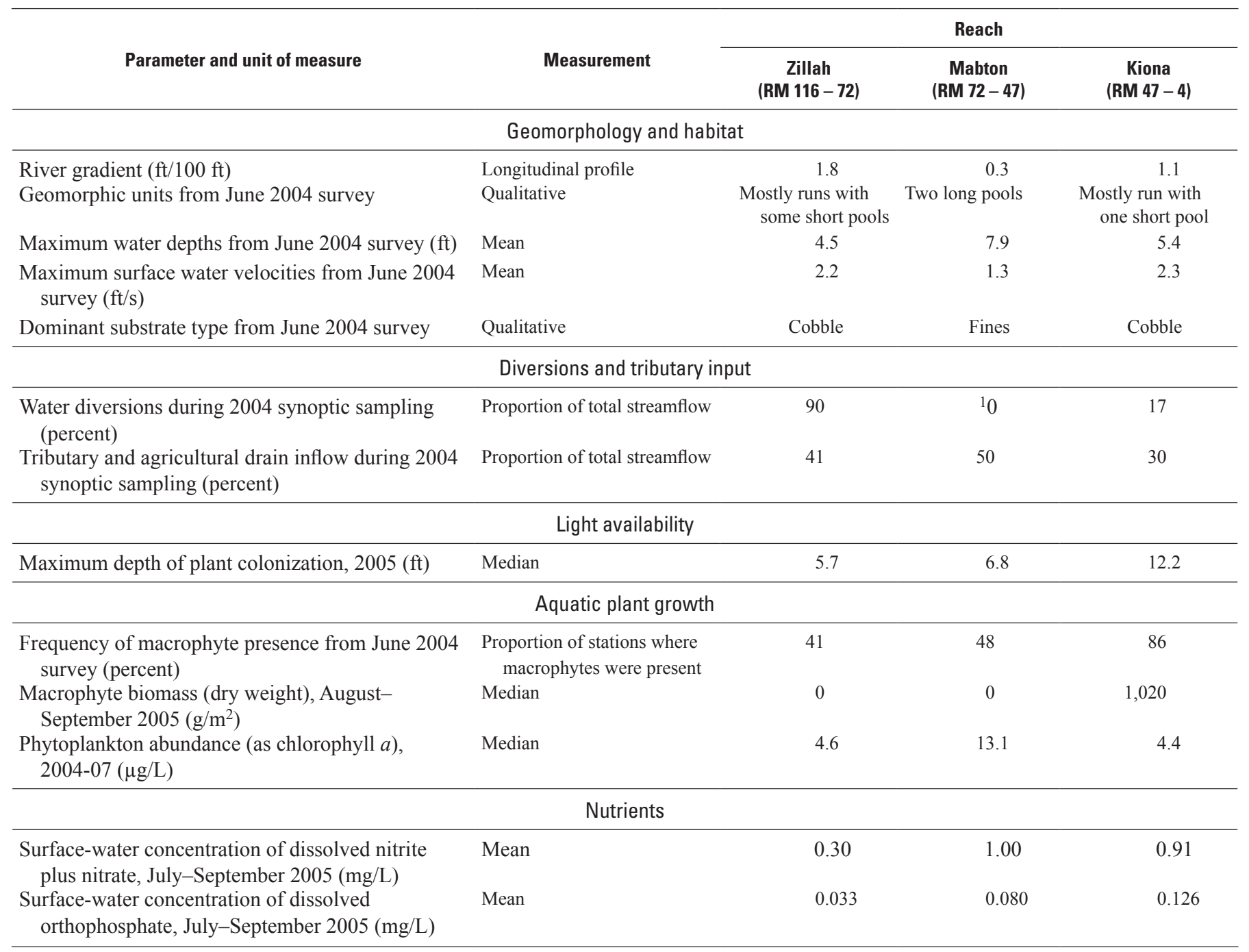

\footnotetext{
${ }^{1}$ The diversion for Chandler Canal is at the end of Mabton reach, but does not affect streamflow in the reach.
}

\section{Longitudinal Patterns in Nutrient, Chlorophyll $a$, and Suspended Sediment Conditions, 2004}

The lowest nutrient concentrations measured during the 2004 synoptic survey were in the Naches River and in the Zillah reach upstream of the major agricultural returns (Granger Drain, Satus Creek, South Drain, and Sulphur Creek Wasteway) that start at about RM 83 (fig. 7). The concentrations of all nutrients except dissolved ammonia increased through the Mabton reach, which contained the major agricultural returns, and remained unchanged or decreased slightly in the Kiona reach. All but one of the Chl $a$ concentrations in the water column were below the nuisance threshold. The exeption was at RM 55 in the Mabton reach. Suspended sediment concentrations generally were low throughout the lower Yakima River during the 2004 synoptic survey (less than $15 \mathrm{mg} / \mathrm{L}$ ), except for a concentration of $53 \mathrm{mg} / \mathrm{L}$ that was measured at RM 61.

The four highest loads of total nitrogen and total phosphorus during the 2004 synoptic survey were measured upstream of the two major irrigation diversions at Parker (RM 104), in the Mabton reach, and at Kiona, whereas the lowest loads were measured in the Zillah reach downstream of the diversions near Parker (fig. 8; appendix E). The largest contributor of total nitrogen and total phosphorus load to the Zillah reach was the Yakima River itself, which delivers nutrients from the Kittitas and Selah valleys. The next largest contributor of total nitrogen load to the Zillah reach was tributary inflow followed by the city of Yakima wastewater treatment plant and the return for Roza Canal. The remainder of the total phosphorus load was contributed almost equally by the city of Yakima wastewater treatment plant, tributaries, 

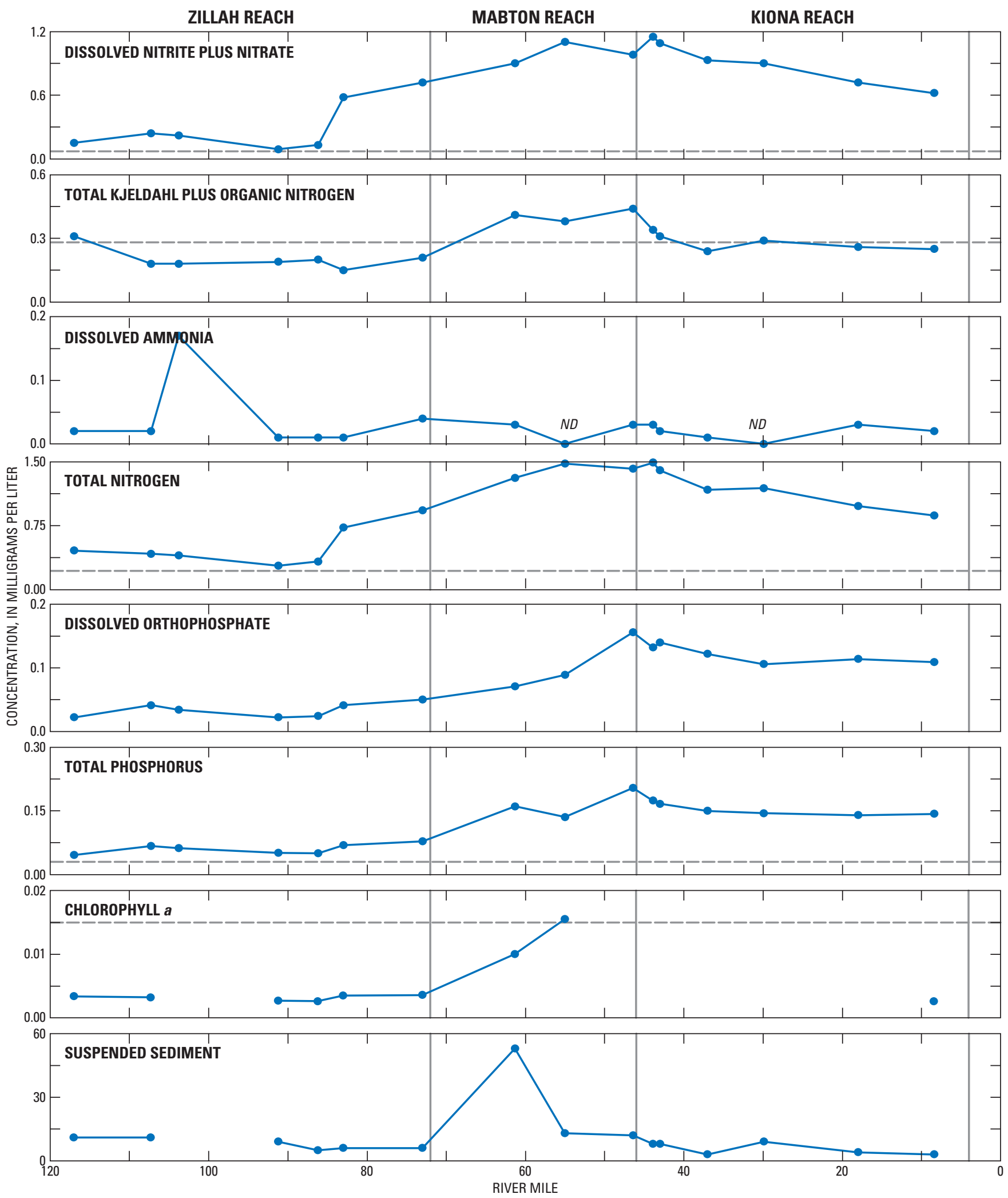

Note: $N D=$ not detected above method reporting limit.

The dashed horizontal lines show the suggested USEPA nutrient criteria for Yakima River basin streams, if applicable, and the State of Oregon nuisance threshold for chlorophyll a

Figure 7. Results from Lagrangian synoptic sampling of nutrients, chlorophyll $a$, and suspended sediment, lower Yakima River, Washington, July 26-July 29, 2004. 


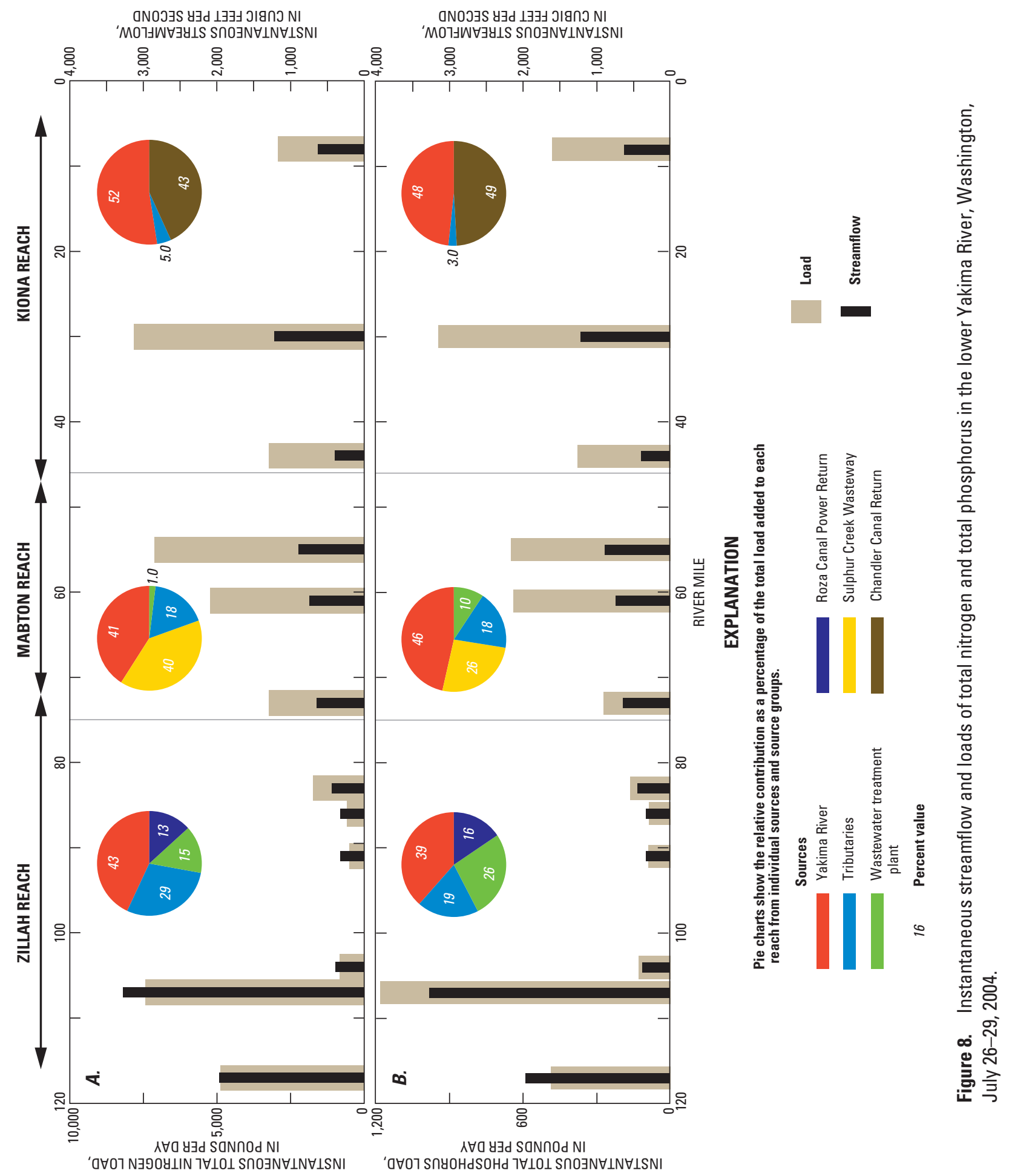


and the return for the Roza Canal. The load of total nitrogen was reduced by 83 percent and the load of total phosphorus was reduced by 74 percent, however, near Parker because of an 80 percent reduction in streamflow due to the diversion of water for irrigation needs. About equal amounts of the loads of total nitrogen and total phosphorus in the Mabton reach came from upstream and from nutrient-rich agricultural return drains (mostly from Sulphur Creek Wasteway) and tributary inputs. Almost all loads of total nitrogen and total phosphorus in the Kiona reach entered from upstream.

\section{Description of Aquatic Plant Occurrence and Biomass 2004-07}

Periphytic algae (primarily diatoms, green algae, and blue-green algae) and several species of rooted macrophytes were observed throughout lower Yakima River during the 2004 qualitative assessment, but the patterns in abundance of algal and macrophyte growth differed considerably between the three reaches (table 3).

\section{Algae}

The Zillah reach was dominated by periphytic algae, including colonial stalked and other types of attached diatoms (Cymbella, Gomphonema, and many others). Filamentous blue-green algae (Oscillatoria) and filamentous green algae (Cladophora, Stigeoclonium, Spirogyra, and Ulothrix), which developed during spring and summer in laminar flow habitats, riffles, and shallow runs, also were present. Periphytic algae were especially abundant in shallow riffles of the Zillah reach, where the Chl $a$ values ranged from 29 to $340 \mathrm{mg} / \mathrm{m}^{2}$ (table 5).

Table 5. Periphyton biomass in the lower Yakima and Naches Rivers, Washington, 2005-07.

[Algal biomass data from the Bureau of Reclamation laboratory, Boise, Idaho. Median values are given where replicates were analyzed. Shading indicates chlorophyll $a$ value that was above nuisance condition level. Abbreviations: Chl $a$, chlorophyll $a$; Pheo- $a$, pheophytin $a ; \mathrm{AFDM}$, ash-free dry mass; mg/m ${ }^{2}$, milligram per square meter; $\mathrm{g} / \mathrm{m}^{2}$, gram per square meter; RM, river mile; USGS, U.S. Geological Survey; -, no data]

\begin{tabular}{|c|c|c|c|c|c|c|c|}
\hline $\begin{array}{c}\text { USGS site } \\
\text { identification } \\
\text { No. }\end{array}$ & Sampling location & $\mathbf{R M}$ & Date & $\begin{array}{l}\text { Number of } \\
\text { samples }\end{array}$ & $\begin{array}{c}\text { Chl } a \\
\left(\mathrm{mg} / \mathrm{m}^{2}\right)\end{array}$ & $\begin{array}{l}\text { Pheo- } a \\
\left(\mathrm{mg} / \mathrm{m}^{2}\right)\end{array}$ & $\begin{array}{l}\text { AFDM } \\
\left(g / m^{2}\right)\end{array}$ \\
\hline \multirow[t]{2}{*}{12494450} & \multirow[t]{2}{*}{ Naches River at RM 12.2 near Naches } & \multirow[t]{2}{*}{12.2} & $07-24$ & 3 & 34 & 3 & 17 \\
\hline & & & 08-07 & 3 & 70 & 5 & 23 \\
\hline 12498690 & Naches River above Diversion Dam near Yakima & 3.5 & 09-03 & 3 & 49 & 4 & 13 \\
\hline \multirow[t]{2}{*}{12498990} & \multirow[t]{2}{*}{ Naches River at 40th Avenue near Yakima } & \multirow[t]{2}{*}{2.8} & $07-24$ & 3 & 20 & 3 & 9 \\
\hline & & & 08-07 & 3 & 46 & 5 & 15 \\
\hline \multicolumn{8}{|c|}{ Zillah Reach, 2005} \\
\hline \multicolumn{8}{|c|}{ Zillah Reach, 2006} \\
\hline 12505045 & Yakima River at RM 102.8 near Parker & 102.8 & $07-11$ & 2 & 255 & 48 & 63 \\
\hline 12505060 & Yakima River at RM 102.6 near Parker & 102.6 & $07-11$ & 2 & 168 & 18 & 42 \\
\hline 12505085 & Yakima River at RM 100.8 near Donald & 100.8 & $07-11$ & 2 & 214 & 31 & 48 \\
\hline 12505090 & Yakima River at RM 100.7 near Donald & 100.7 & $07-11$ & 2 & 82 & 10 & 29 \\
\hline 1250532100 & $\begin{array}{l}\text { Yakima River below North Myers Road Bridge right bank } \\
\text { near Zillah }\end{array}$ & 91.0 & $07-12$ & 2 & 340 & 26 & 58 \\
\hline 1250532110 & $\begin{array}{l}\text { Yakima River below North Myers Road Bridge left bank } \\
\text { near Zillah }\end{array}$ & 91.0 & $07-12$ & 2 & 178 & 26 & 61 \\
\hline
\end{tabular}




\section{Assessment of Eutrophication in the Lower Yakima River Basin, Washington, 2004-07}

Table 5. Periphyton biomass in the lower Yakima and Naches Rivers, Washington, 2005-07._Continued

[Algal biomass data from the Bureau of Reclamation laboratory, Boise, Idaho. Median values are given where replicates were analyzed. Shading indicates chlorophyll $a$ value that was above nuisance condition level. Abbreviations: Chl $a$, chlorophyll $a$; Pheo- $a$, pheophytin $a$; AFDM, ash-free dry mass; mg/m², milligram per square meter; $\mathrm{g} / \mathrm{m}^{2}$, gram per square meter; RM, river mile; USGS, U.S. Geological Survey; -, no data]

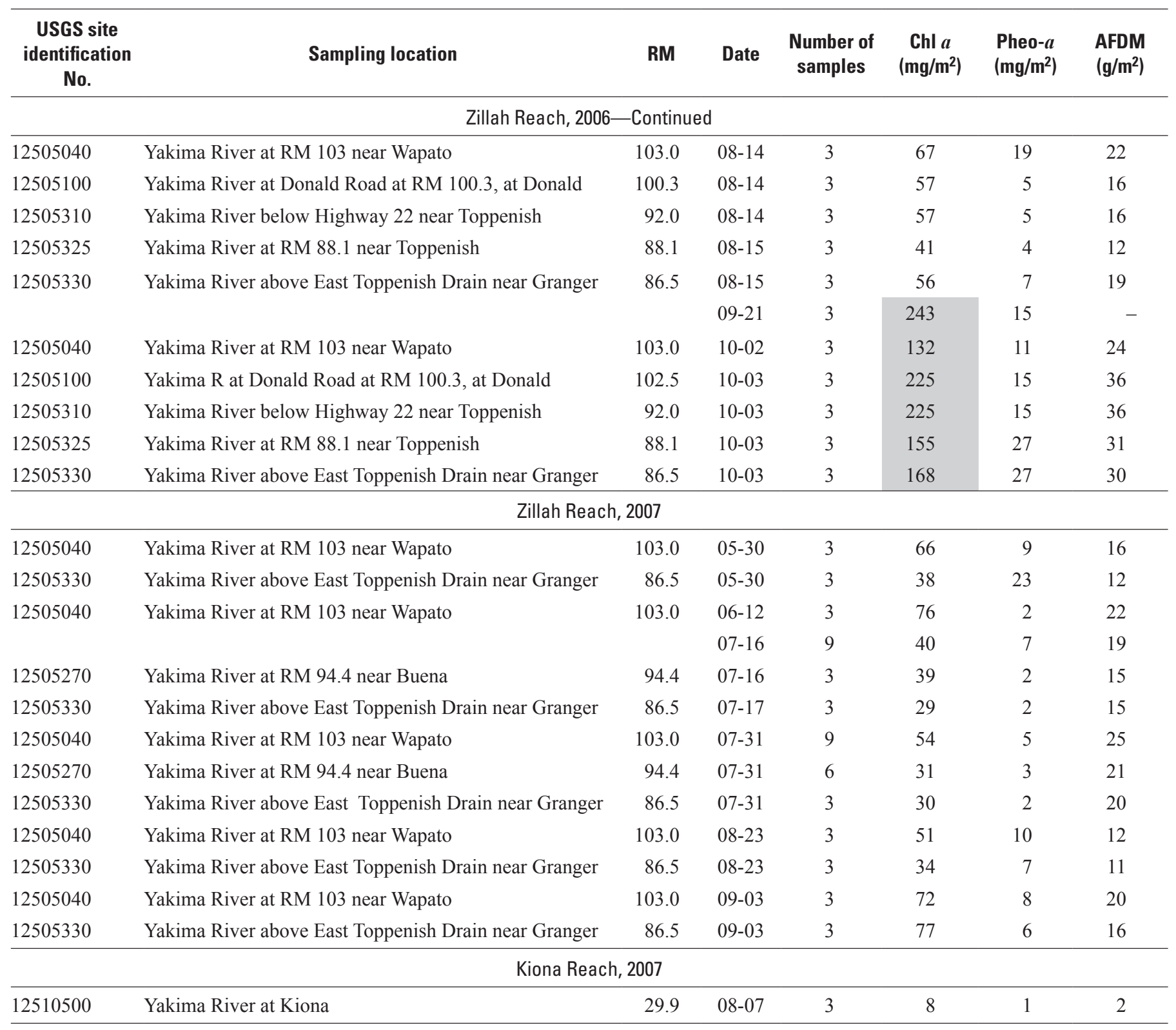


The median Chl $a$ in the Zillah reach was $80 \mathrm{mg} / \mathrm{m}^{2}$ about two times greater than the median for the Naches River (44 mg/m²; range $20-70 \mathrm{mg} / \mathrm{m}^{2}$ ). The median AFDM also was higher in the Zillah reach $\left(24 \mathrm{~g} / \mathrm{m}^{2}\right.$, range $\left.11-147 \mathrm{~g} / \mathrm{m}^{2}\right)$ than in the Naches River $\left(15 \mathrm{~g} / \mathrm{m}^{2}\right.$, range $\left.9-23 \mathrm{~g} / \mathrm{m}^{2}\right)$. Thirty-nine percent of the samples obtained from the Zillah reach during 2005-07 exceeded the nuisance threshold of $100 \mathrm{mg} / \mathrm{m}^{2}$ for $\mathrm{Chl} a$, but all the samples that exceeded $100 \mathrm{mg} / \mathrm{m}^{2}$ were collected in 2006 and no samples collected in the Zillah reach between July and September 2007 exceeded $100 \mathrm{mg} / \mathrm{m}^{2}$. The median Chl $a$ and AFDM levels in the Zillah reach in 2006 were significantly greater than the median levels in the Zillah reach and Naches River in 2007, but the median levels in the Zillah reach and Naches River in 2007 were not significantly different from each other (fig. 9).

Algal biomass measured on the cobble and gravel substrates in the Zillah reach and Naches River were positively related to near-bed water velocity (relation not shown). The median $\mathrm{Chl} a$ of 14 samples collected where the near-bed velocity was less than $0.7 \mathrm{ft} / \mathrm{s}$ was $162 \mathrm{mg} / \mathrm{m}^{2}$, compared to $47 \mathrm{mg} / \mathrm{m}^{2}$ for 6 samples collected where the near-bed velocity was greater than $0.7 \mathrm{ft} / \mathrm{s}$. The median AFDM of 14 samples collected where the near-bed velocity was less than $0.7 \mathrm{ft} / \mathrm{s}$ was $31 \mathrm{~g} / \mathrm{m}^{2}$, compared to $17 \mathrm{~g} / \mathrm{m}^{2}$ for 6 samples collected where the near-bed velocity was greater than $0.7 \mathrm{ft} / \mathrm{s}$.

Phytoplankton was the dominant type of aquatic plant in the Mabton reach, but some sparse patches of periphyton also were observed. Concentrations of water-column Chl $a$ in the Mabton reach were consistently higher than concentrations in the other reaches. The median water-column $\mathrm{Chl} a$ concentration in the Mabton reach was $13.1 \mu \mathrm{g} / \mathrm{L}$, compared to median concentrations of 4.6 and $4.4 \mu \mathrm{g} / \mathrm{L}$ in the Zillah and Kiona reaches, respectively (table 6).

Algal abundance in the Kiona reach during the 2004 qualitative assessment was moderate to high and was dominated by diatoms and filamentous green algae. Several types of periphyton also were observed attached to macrophytes at that time.
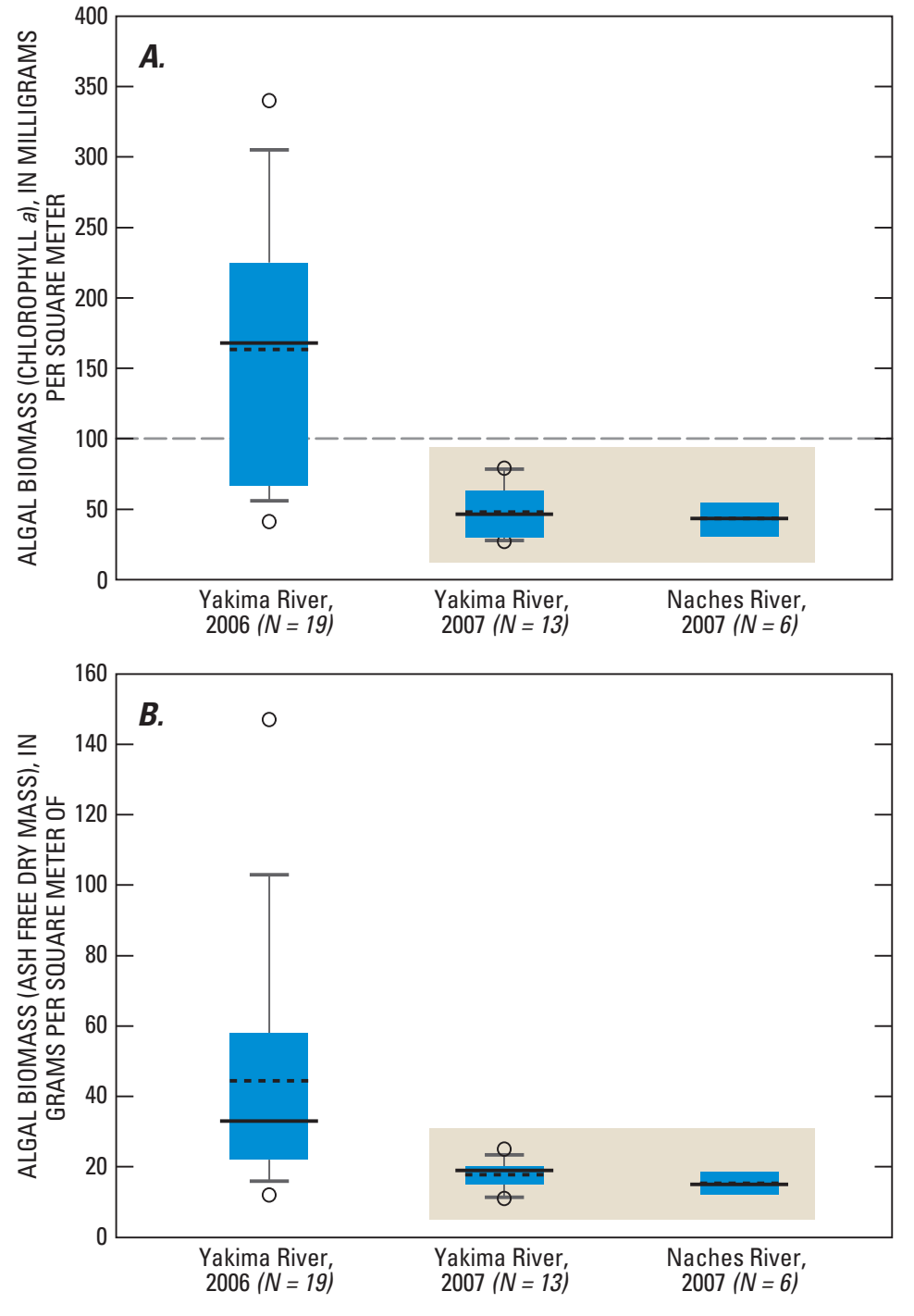

EXPLANATION

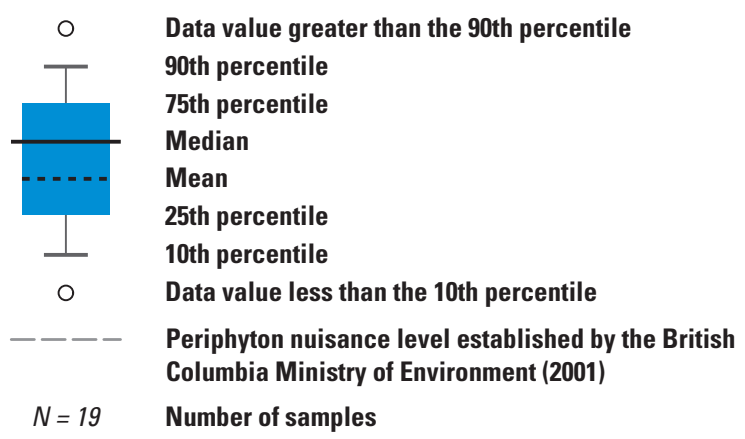

Note: The box encloses groups of data with overlapping 95 percent confidence intervals for the median (as determined using a pair-wise Wilcoxon signed rank comparison).

Figure 9. Periphytic algal biomass measured in the Zillah reach between RM 103 and 87, Yakima River, July-0ctober 2006 and July-September 2007, and in the Naches River, Washington, between RM 11.5 and 2.8, July-September 2007. 
24 Assessment of Eutrophication in the Lower Yakima River Basin, Washington, 2004-07

Table 6. Planktonic (water column) chlorophyll $a$ in the lower Yakima and Naches Rivers, Washington, 2004-05.

[Point (grab) sample concentration data given in micrograms per liter $(\mu \mathrm{g} / \mathrm{L})$. Samples analyzed spectrophotometrically by the Bureau of Reclamation Laboratory, Boise, Idaho. Shading indicates chlorophyll $a$ value that was above nuisance condition level. Abbreviation: RM, river mile]

\begin{tabular}{|c|c|c|c|c|}
\hline $\begin{array}{c}\text { USGS site } \\
\text { identification } \\
\text { No. }\end{array}$ & Site name & RM & Date & $\begin{array}{c}\text { Chlorophyll a } \\
\text { ( } \mu \mathrm{g} / \mathrm{L})\end{array}$ \\
\hline \multicolumn{5}{|c|}{ Naches Reach } \\
\hline \multirow[t]{2}{*}{12499000} & \multirow[t]{2}{*}{ Naches River near North Yakima } & 1.0 & $05-24-04$ & 2.2 \\
\hline & & & 06-30-04 & 0.8 \\
\hline \multicolumn{5}{|c|}{ Zillah Reach } \\
\hline \multirow[t]{3}{*}{12487000} & \multirow[t]{3}{*}{ Yakima River at Selah Gap near North Yakima } & 117.0 & $07-26-04$ & 3.4 \\
\hline & & & $05-24-04$ & 5.3 \\
\hline & & & $06-28-04$ & 5.1 \\
\hline 12500450 & Yakima River above Ahtanum Creek at Union Gap & 107.3 & 07-26-04 & 3.2 \\
\hline \multirow[t]{2}{*}{12504490} & \multirow[t]{2}{*}{ Sunnyside Canal at Diversion near Parker } & 103.8 & $05-25-04$ & 4.6 \\
\hline & & & 06-30-04 & 2.5 \\
\hline 12505330 & Yakima River above East Toppenish Drain near Granger & 86.5 & $06-23-05$ & 6.6 \\
\hline 12505320 & Yakima River at RM 91 at Zillah & 91.2 & $07-27-04$ & 2.7 \\
\hline \multirow[t]{11}{*}{12505330} & \multirow[t]{11}{*}{ Yakima River above East Toppenish Drain near Granger } & \multirow[t]{11}{*}{86.5} & 04-05-05 & 19.2 \\
\hline & & & 04-27-05 & 17.5 \\
\hline & & & 04-19-05 & 11.1 \\
\hline & & & $05-24-04$ & 7.8 \\
\hline & & & 05-19-05 & 7.2 \\
\hline & & & $06-23-05$ & 6.6 \\
\hline & & & $06-28-05$ & 6.5 \\
\hline & & & $10-13-05$ & 4.4 \\
\hline & & & 08-18-05 & 2.8 \\
\hline & & & $06-28-04$ & 2.7 \\
\hline & & & $07-27-04$ & 2.6 \\
\hline 12505440 & Yakima River at Bridge Avenue at Granger & 83.0 & $07-27-04$ & 3.5 \\
\hline 12507580 & Yakima River above Satus Creek at RM 73 near Satus & 73.0 & 07-27-04 & 3.6 \\
\hline \multicolumn{5}{|c|}{ Mabton Reach } \\
\hline \multirow[t]{3}{*}{12507584} & \multirow[t]{3}{*}{ Yakima River at Murray Road near Sunnyside } & 72.0 & $05-25-04$ & 8.9 \\
\hline & & & 06-30-04 & 4.8 \\
\hline & & & 09-21-04 & 4.5 \\
\hline 12508680 & Yakima River above Sulphur Creek at RR 61.3 near Mabton & 61.3 & 07-28-04 & 10.8 \\
\hline
\end{tabular}


Table 6. Planktonic (water column) chlorophyll $a$ in the lower Yakima and Naches Rivers, Washington, 2004-05. - Continued

[Point (grab) sample concentration data given in micrograms per liter $(\mu \mathrm{g} / \mathrm{L})$. Samples analyzed spectrophotometrically by the Bureau of Reclamation Laboratory, Boise, Idaho. Shading indicates chlorophyll $a$ value that was above nuisance condition level. Abbreviation: RM, river mile]

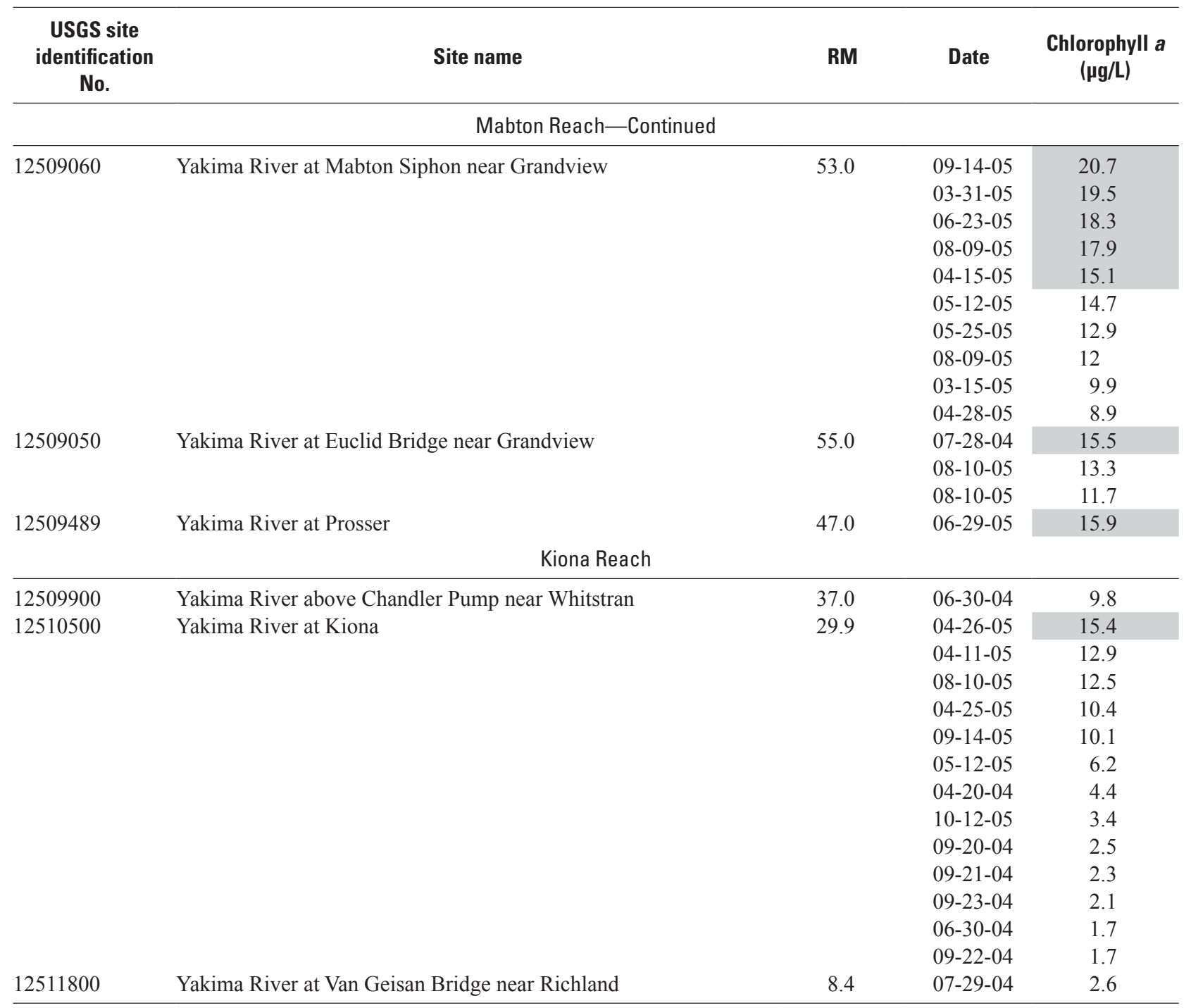




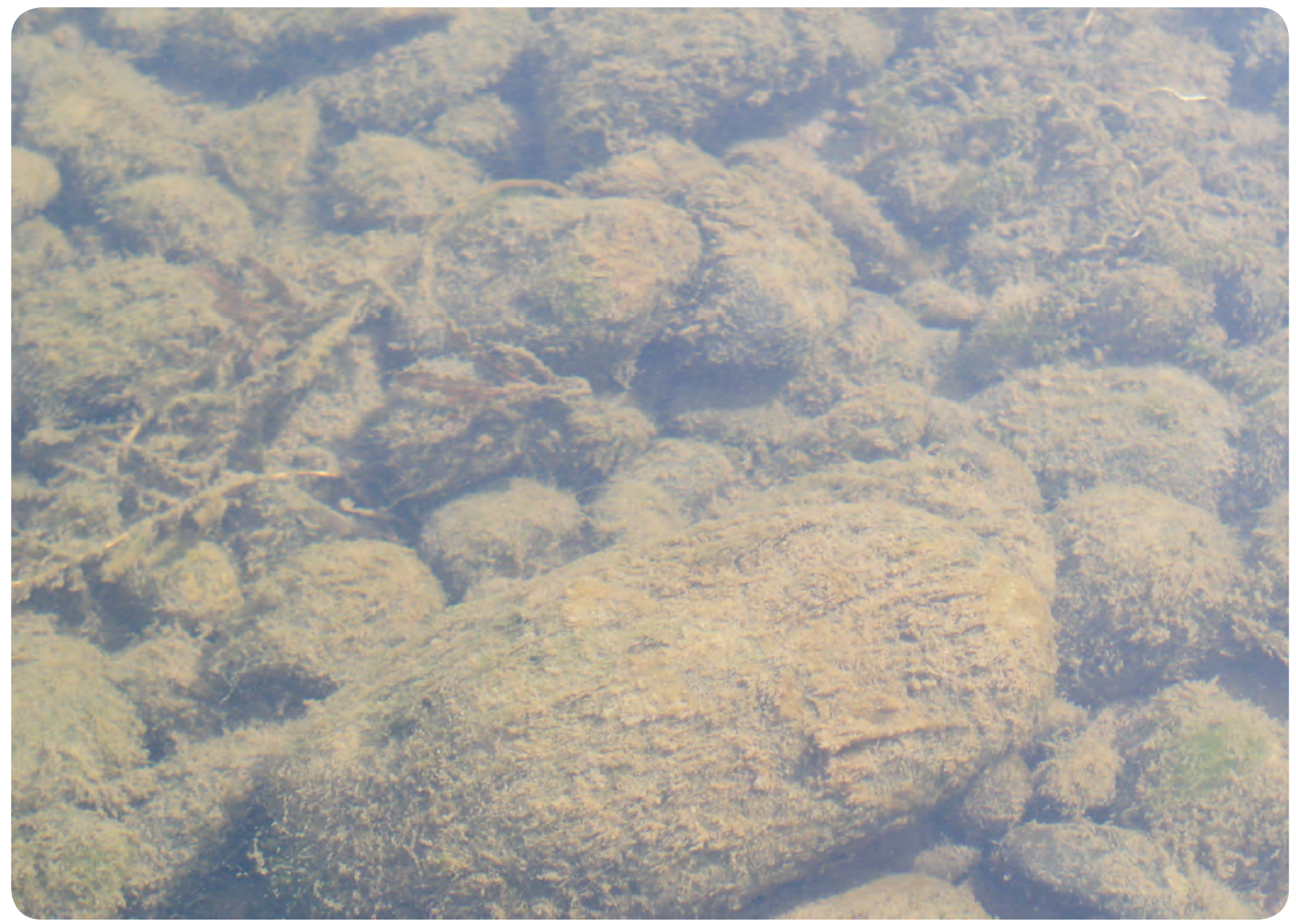

Periphytic algae in the Yakima River near Zillah, Washington. (Phoograph by Marie Zuroske, South Yakima Conservation District, August 2007.)

\section{Macrophytes}

Macrophyte growth was moderate-to-abundant in the Kiona reach and dominated by water stargrass (Heteranthera dubia), which extended across the entire river in many places in 2004 and 2005. In the Zillah reach, macrophyte growth generally was sparse-to-moderate and dominated by curlyleaf pondweed (Potomogeton crispus), but other species were present - common waterweed (Elodea sp.), sago pondweed (Potamogeton pectinatus), American pondweed (Potamogeton nodosus), and coontail (Ceratophyllum demersum).

Macrophytes were less abundant in the Mabton reach than in the other two reaches - generally sparse and only present near the river's edge. In late August 2005, the median dry weight of macrophyte biomass measured in the Kiona reach was $1,020 \mathrm{~g} / \mathrm{m}^{2}$. Although some macrophyte growth was measured in the Mabton and Zillah reaches during the sampling in 2005, the median values for both reaches were equal to zero because most of the quadrats contained no macrophytes.
The concentrations of total nitrogen and total phosphorus content measured in a limited number of the macrophyte tissue samples obtained from the Zillah and Kiona reaches in 2005 (table 7) were above the critical concentrations of 1.6 percent for nitrogen and 0.14 percent for phosphorus (Madsen, 1988), indicating that macrophyte growth was not limited by either of these nutrients in these reaches.

Macrophyte abundance was substantially greater in the Kiona reach in 2005 than in 2006 and 2007, with median biomass values of $1,020,32$, and $84 \mathrm{~g} / \mathrm{m}^{2}$ in 2005,2006 , and 2007, respectively (table 8). A comparison of the 95 percent confidence intervals for median biomass showed that the median biomass was significantly greater in 2005 compared to 2006 and 2007, but that the medians in 2006 and 2007 were not significantly different.

Although there was no strong linear relation between macrophyte biomass and either water depth or water velocity in the Kiona reach at the locations sampled in 2005-07, macrophyte biomass was consistently lower and less variable where depths were greater than $8 \mathrm{ft}$ and velocities were greater than about $1.8 \mathrm{ft} / \mathrm{s}$ (正. 10). 
Table 7. Total nitrogen and total phosphorus content of macrophyte tissues collected in the Zillah reaach (near river mile 87) and the Kiona reach (near river mile 21) of the Yakima River, Washington, August 30-September 2, 2005.

[Values are percentages based on dried weight and are the means for all samples. The range in values is shown in parentheses. Samples in the Zillah reach were collected September 2, 2005 and samples in the Kiona reach were collected August 30, 2005. Abbreviation: n, number of samples]

\begin{tabular}{lcc}
\hline \multicolumn{1}{c}{$\begin{array}{c}\text { Parameter } \\
\text { (percent) }\end{array}$} & $\begin{array}{c}\text { Zillah reach } \\
(\mathbf{n}=\mathbf{3})\end{array}$ & $\begin{array}{c}\text { Kiona Reach } \\
(\mathbf{n}=\mathbf{8})\end{array}$ \\
\hline Total nitrogen content & $3.52(3.41-3.64)$ & $2.61(2.44-3.12)$ \\
Total phosphorus content & $0.45(0.39-0.49)$ & $0.42(0.29-0.54)$ \\
\hline
\end{tabular}

Table 8. Summary of macrophyte biomass measured in the Kiona reach of the Yakima River, Washington, near river mile 21, 2005-07.

\begin{tabular}{|c|c|c|c|c|c|c|}
\hline \multirow{3}{*}{ Transect } & \multicolumn{6}{|c|}{$\begin{array}{l}\text { Median dry weight } \\
\text { (grams per square meter) }\end{array}$} \\
\hline & \multicolumn{2}{|c|}{2005} & \multicolumn{2}{|c|}{2006} & \multicolumn{2}{|c|}{2007} \\
\hline & $\begin{array}{l}\text { August } 30- \\
\text { September } 2\end{array}$ & $\begin{array}{l}\text { Number of } \\
\text { samples } \\
\text { collected }\end{array}$ & September 1 & $\begin{array}{l}\text { Number of } \\
\text { samples } \\
\text { collected }\end{array}$ & September 7 & $\begin{array}{l}\text { Number of } \\
\text { samples } \\
\text { collected }\end{array}$ \\
\hline T1 (upstream) & 913 & 5 & 0 & 4 & 0 & 5 \\
\hline $\mathrm{T} 2$ & 836 & 5 & 12 & 4 & 0 & 5 \\
\hline $\mathrm{T} 3$ & 1,034 & 5 & 37 & 5 & 378 & 5 \\
\hline $\mathrm{T} 4$ & 566 & 5 & 48 & 5 & 230 & 5 \\
\hline T5 & 1,769 & 3 & 236 & 4 & 91 & 5 \\
\hline T6 (downstream) & 1,354 & 5 & 486 & 5 & 634 & 5 \\
\hline All samples & 1,020 & 28 & 32 & 27 & 84 & 30 \\
\hline $\begin{array}{l}95 \text { percent confidence } \\
\text { interval }\end{array}$ & $723-1,495$ & & $19-171$ & & $70-472$ & \\
\hline
\end{tabular}
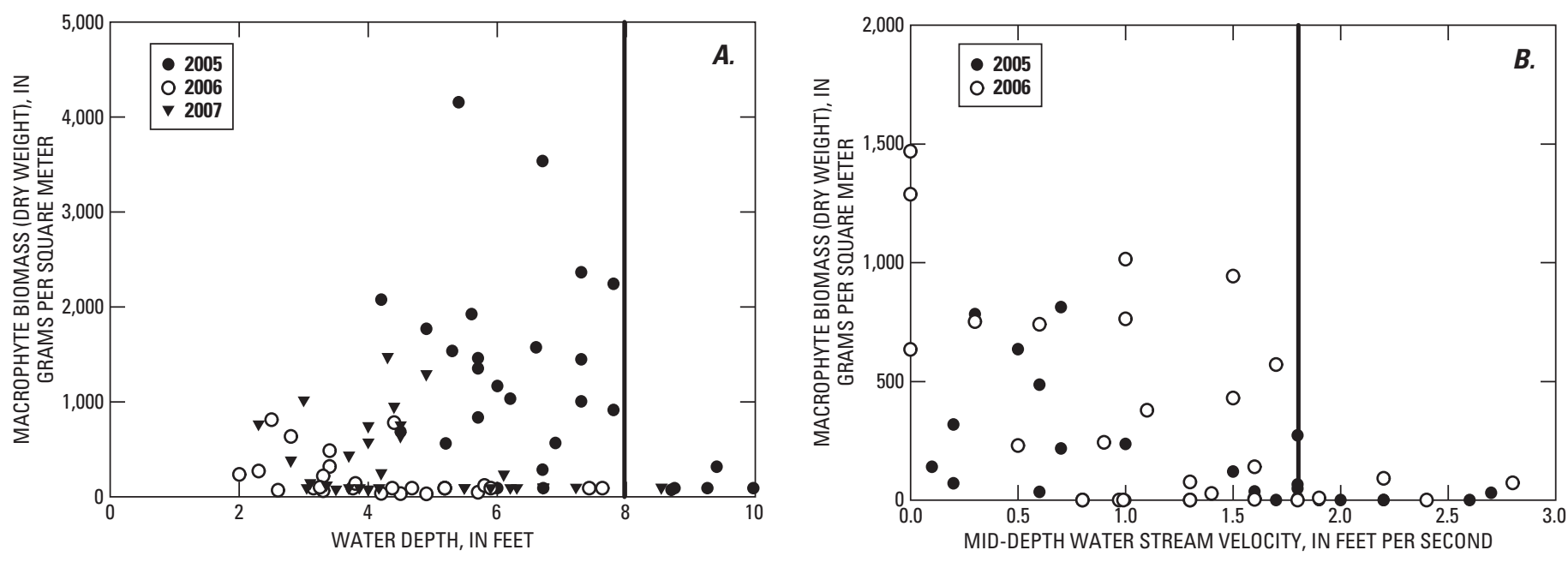

Note: The vertical lines on the plots show the breaks at 8 feet and 1.8 feet per second between large scatter in the values for macrophyte biomass and consistently low values for macrophyte biomass.

Figure 10. Relation between macrophyte biomass and $(A)$ water depth and $(B)$ mid-depth stream velocity in the Kiona reach near RM 18, Yakima River, Washington 2005-07. 


\section{Measuring Macrophyte Abundance Indirectly}

To understand the possible factors responsible for the abundant macrophyte growth in 2005 followed by a sharp decrease in 2006 and 2007, the relative abundance of macrophytes was assessed for the years immediately prior to the study. No macrophyte abundance data were available for the Yakima River prior to the measurements made in 2005 for this study. The relation between depth and discharge ("the rating curve") for the Yakima River at Kiona is well established, however, and a shift to the rating curve is applied when this relation changes due to changes in the river. Because the recent increase in summer macrophyte growth in the Yakima River at Kiona caused the water depth to increase under the same streamflow, shifts to the rating curve for the station have been necessary. The values for these shifts are an indirect measure of macrophyte abundance at the Kiona station because they show the increase in water depth for the same streamflow. From 1996 (when the last major flood occurred) through 2000, rating shifts were not needed or were negligible. Beginning with the drought of 2001, however, rating curve shifts became more frequent and greater in magnitude. By 2005, macrophyte growth during summer was abundant enough to result in a 3-ft increase in water depth compared to prior years for the same streamflow. Shifts were applied to the rating curve at Kiona in 2006 and 2007, but they were much less than those applied in 2005, indicating decreased macrophyte growth.

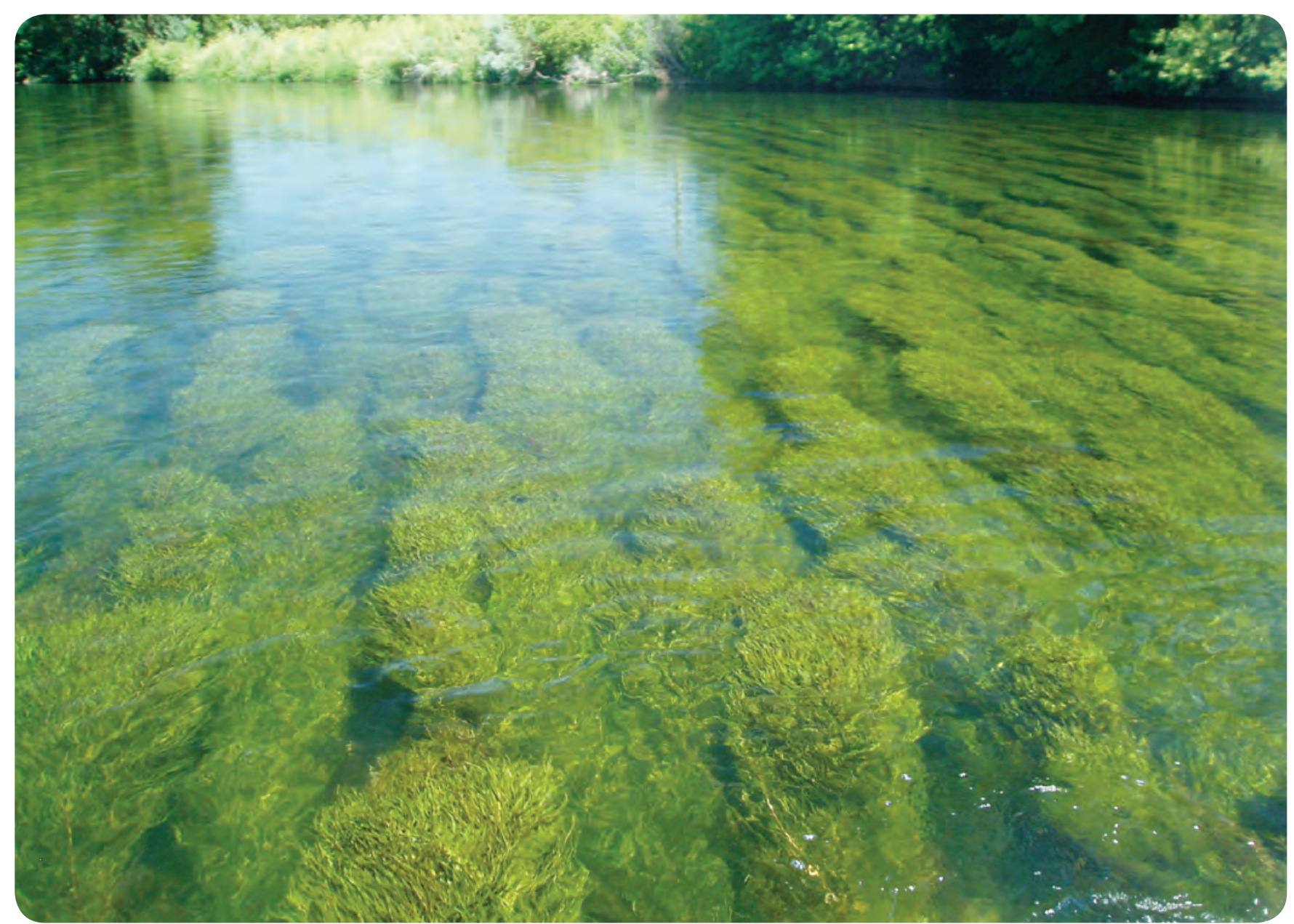

Water stargrass beds in the Yakima River near Kiona, Washington, when water turbidity was about 0 FNU. (Photograph by Kurt Carpenter, U.S. Geological Survey, July 2005.) 


\section{Effects of Aquatic Plant Growth on Dissolved Oxygen and pH Conditions}

The diverse aquatic-plant and heterotrophic assemblages in lower Yakima River had pronounced effects on water quality by causing large daily fluctuations in dissolved oxygen concentrations and $\mathrm{pH}$. These effects on dissolved oxygen and $\mathrm{pH}$ conditions were observed during the growing season in all three reaches of the lower Yakima River, but they varied between seasons, between years, and between reaches.

Periphyton likely was the aquatic plant most responsible for the daily swings in dissolved oxygen and $\mathrm{pH}$ in the Zillah reach, because the macrophyte growth was sparse and the relatively low summer concentrations of $\mathrm{Chl} a$ in the water column (fig. 11C) indicated that phytoplankton production was minimal in this reach. The median daily ranges in dissolved oxygen concentration and $\mathrm{pH}$ in the Zillah reach were $4.6 \mathrm{mg} / \mathrm{L}$ and 1.5 units between March 1 and June 30,2005 , and the median daily ranges in dissolved oxygen concentration and $\mathrm{pH}$ between March 1 and June 30, 2006 were $1.7 \mathrm{mg} / \mathrm{L}$ and 0.6 units. The difference between 2005 and 2006 apparently was due to the combined effects of dilution from higher streamflow and deeper and more turbid water that reduced light available for algal photosynthesis. In contrast to spring conditions, the median daily range in dissolved oxygen concentration and $\mathrm{pH}$ in the Zillah reach between July 1 and September 30, 2005 was exactly the same as the median daily range between July 1 and September 30, 2006 (4.4 mg/L and $1.4 \mathrm{pH}$ units).

Although macrophyte and algal abundance in the Mabton reach was less than in the Zillah and Kiona reaches, signs of productivity occurred nearly continuously from March through September 2005 - the median daily ranges in dissolved oxygen concentration and $\mathrm{pH}$ were $3 \mathrm{mg} / \mathrm{L}$ and 0.6 units respectively, with numerous cycles of growth and productivity in 2005 that likely were associated with phytoplankton growth (fig. 11B). The large increase in the daily median total chlorophyll concentration $(9-28 \mu \mathrm{g} / \mathrm{L})$ in the Mabton reach in late May and early June 2005 (compared to $3-6 \mu \mathrm{g} / \mathrm{L}$ in early May and mid-June), along with supersaturated dissolved oxygen conditions (220 percent saturation) and $\mathrm{pH}$ as high as 9.2 units (fig. $11 B$ ) indicated that an algal bloom could have occurred in this reach. During this time the total chlorophyll values measured at the monitor installed upstream in the Zillah reach were not elevated, which also indicated that a phytoplankton bloom (rather than periphyton sloughing) had occurred in the Mabton reach.

\section{Dissolved Oxygen in Water}

Streams gain oxygen from the atmosphere and from photosynthesizing aquatic plants. Water at higher temperature and under lower atmospheric pressure dissolves less oxygen than water at lower temperature and higher atmospheric pressure. Oxygen in a stream is consumed when respiration by aquatic animals, plants, decomposition, and various chemical eactions occur. Dissolved oxygen saturation is a measure of the concentration of dissolved oxygen relative to the equilibrium concentration, which is based on water temperature and atmospheric pressure. The degree of dissolved oxygen saturation is influenced by stream turbulence and metabolic ctivity by plants, animals, and bacteria.
Signs of plant productivity occurred nearly continuously in the Kiona reach between March 1 and September 30 in 2004 and 2005 (fig. 11A), which was consistent with the abundant macrophyte growth observed during the low to extremely low spring streamflows in those years. The effects of plant productivity were suppressed, however, during the average snowmelt periods that occurred between March and June in 2006 and 2007. The median daily ranges in dissolved oxygen concentrations between March 1 and June 30 in 2004-07 were $4.8,5.7,0.9$, and $1.0 \mathrm{mg} / \mathrm{L}$, respectively, and the median daily ranges in $\mathrm{pH}$ were $1.1,0.9,0.2$, and 0.3 units. In contrast to the spring results, no significant differences were noted between the median daily ranges between July 1 and September 30, 2004-07 in dissolved oxygen concentrations $(6.1,6.7,6.9$, and $7.0 \mathrm{mg} / \mathrm{L}$, respectively) and $\mathrm{pH}(1.0,1.1$, 1.0 , and 1.1 units, respectively).

\section{Water Temperature, Dissolved Oxygen, pH, and Turbidity Conditions}

\section{Yakima and Naches Rivers, 2004}

The daily maximum water temperature during 2004 was greater than the Washington State standard of $21^{\circ} \mathrm{C}$ during each monitor deployment in the Zillah and Mabton reaches from late June through late August, and in the Kiona reach from early June through early September (fig. 12A). The water was generally clear during the 2004 irrigation season throughout the lower Yakima River and in the Naches River (fig. 13) - the daily median turbidity was less than 10 FNU during almost all monitor deployments. The turbidity generally was greatest in the Mabton reach and lowest in the Kiona reach. 
A. Kiona

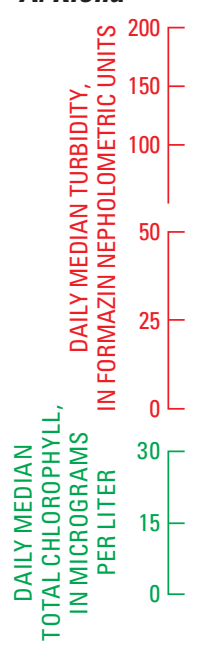

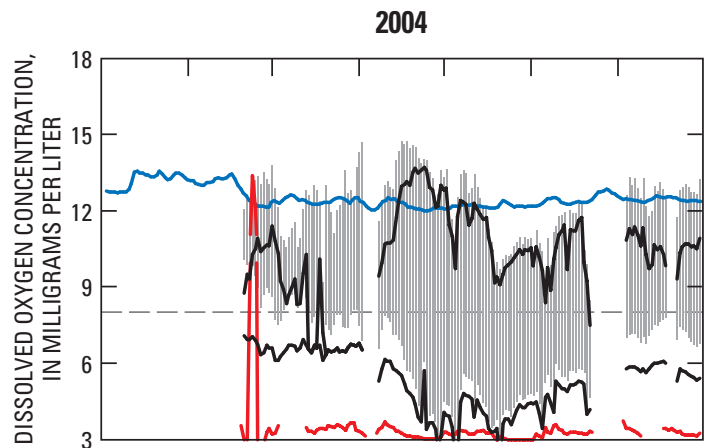
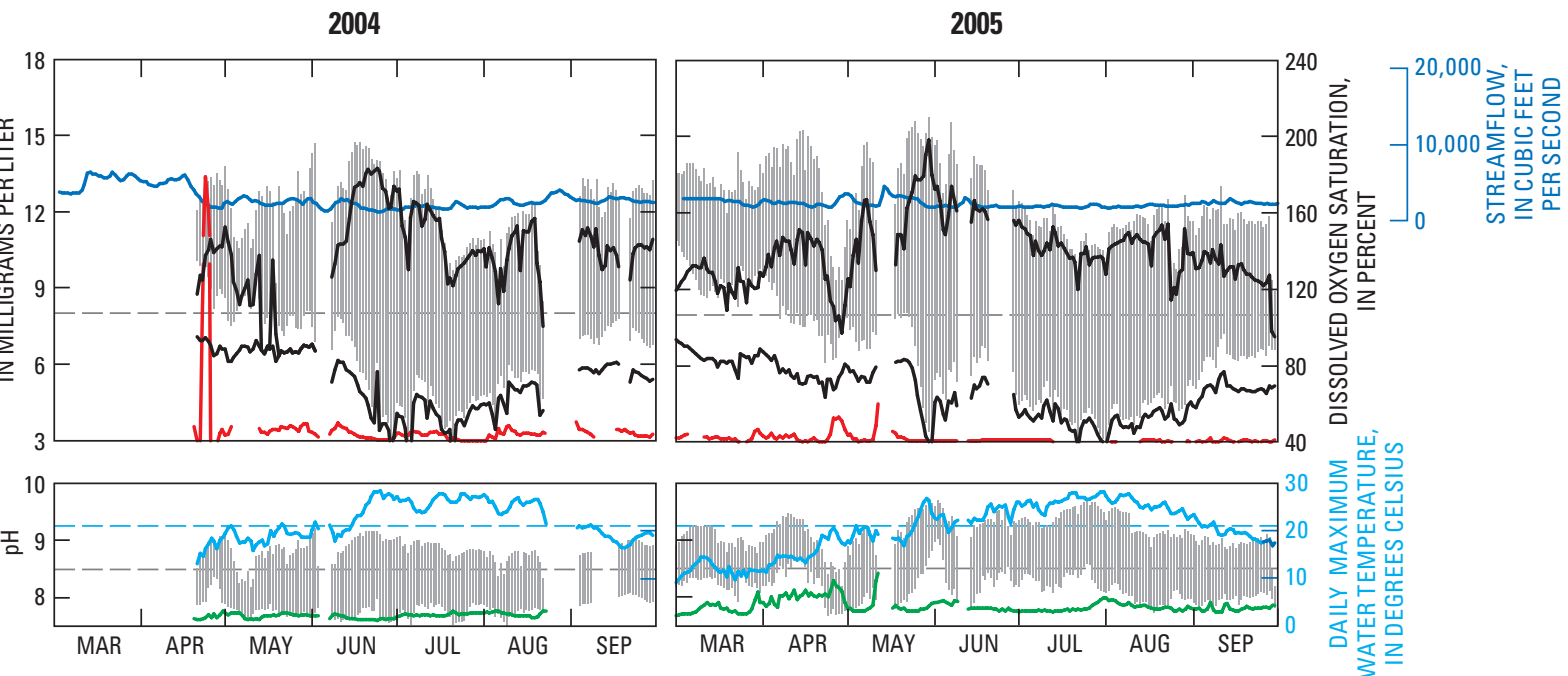

\section{B. Mabton}

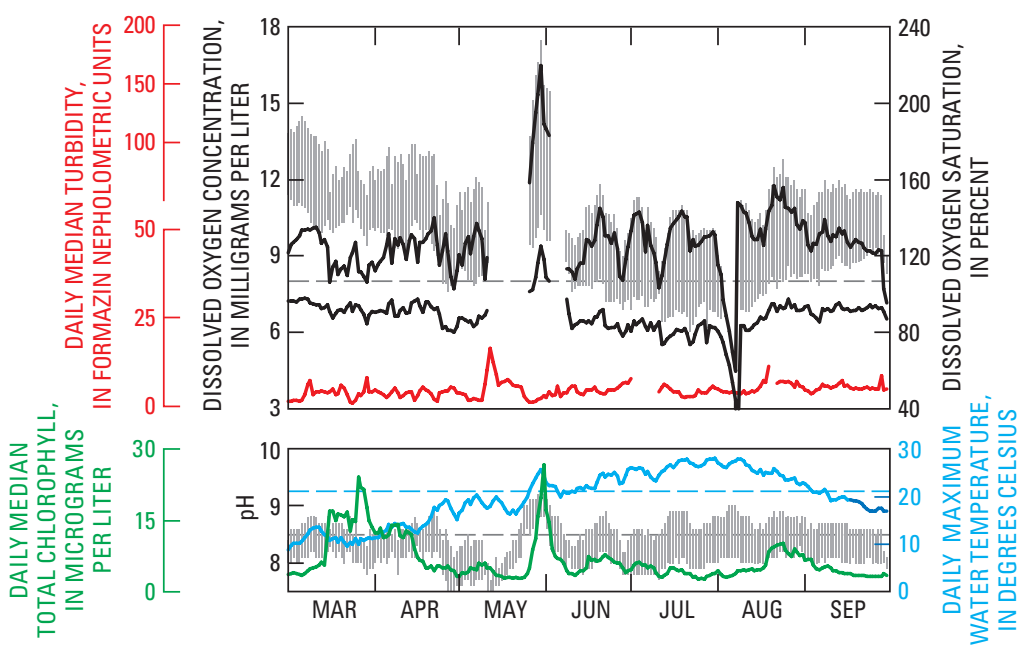

C. Zillah

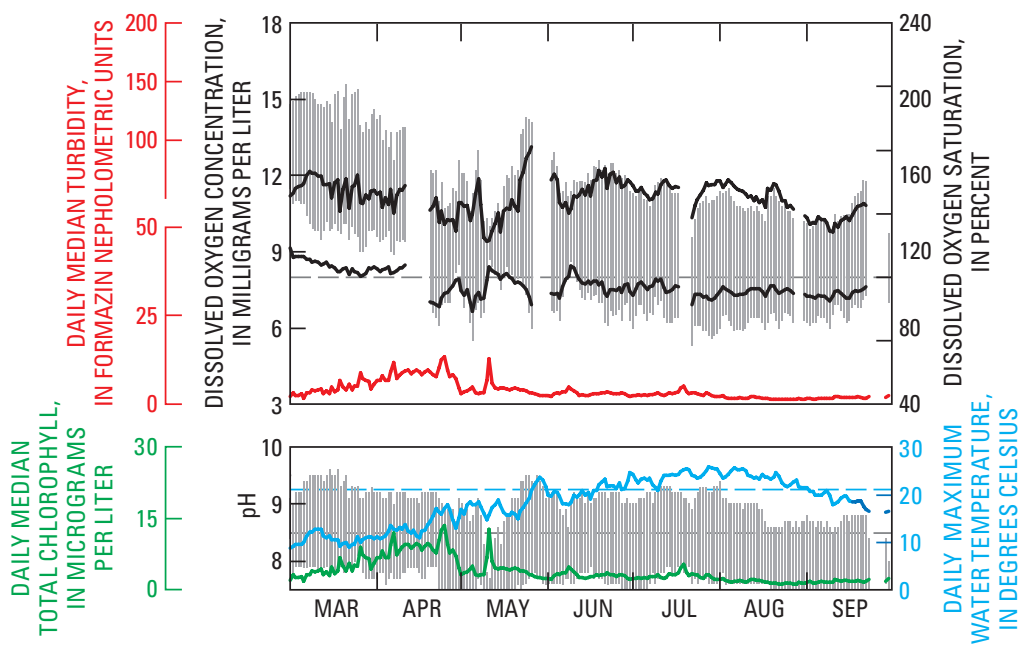

Figure 11. Streamflow, dissolved oxygen concentrations, dissolved oxygen saturation, $\mathrm{pH}$ levels, total chlorophyll, turbidity, and temperature results from continuous monitoring in the Yakima River at (A) Kiona (RM 30), (B) Mabton (RM 55), and (C) Zillah (RM 87), Washington, March 1-September 30, 2004-07. 


\section{A. Kiona (continued)}
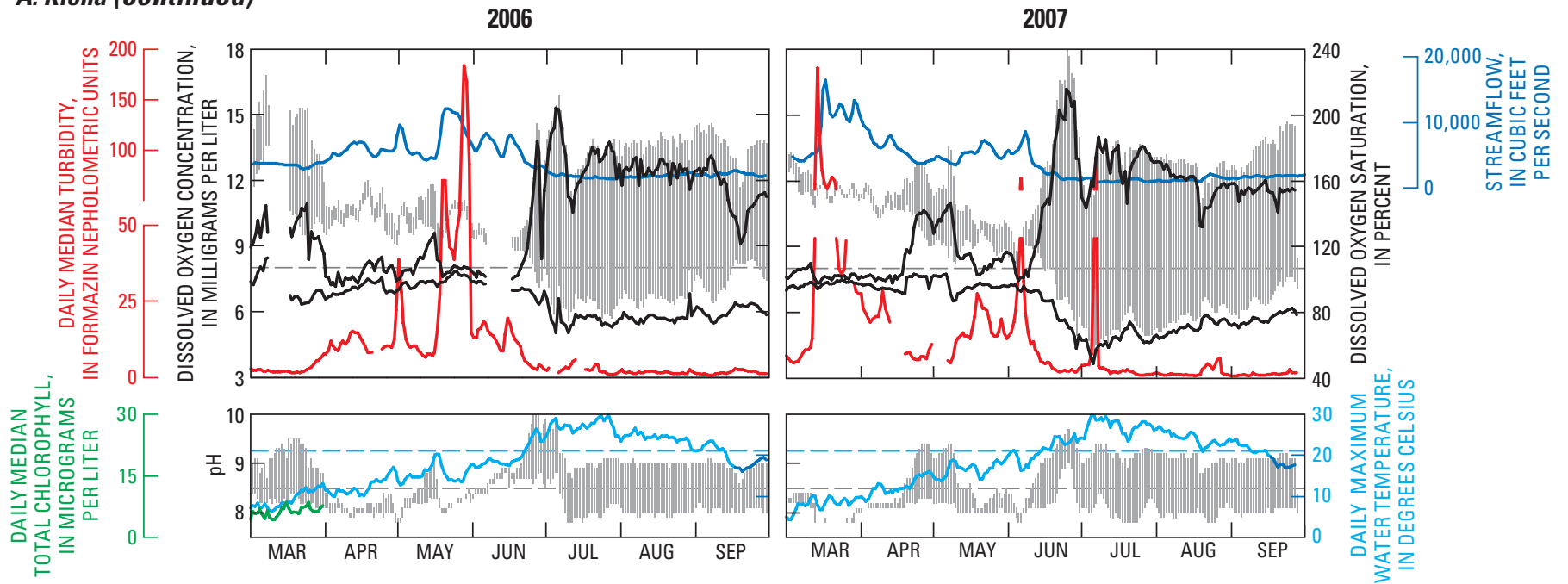

\section{EXPLANATION}

Range in dissolved oxygen concentration and $\mathrm{pH}$ during each day.

Minimum and maximum dissolved oxygen percent saturation for each day.

Median total chlorophyll concentration for each day. When aggregated together, the total chlorophyll results from the monitor deployments were not significantly correlated

with the chlorophyll a results measured using standard laboratory methods.

Median turbidity values for each day.

Maximum water temperature readings for each day.

Average streamflows for each day.

Washington State water-quality standards for dissolved oxygen and pH

Washington State water-quality standard for water temperature.

\section{Zillah (continued)}

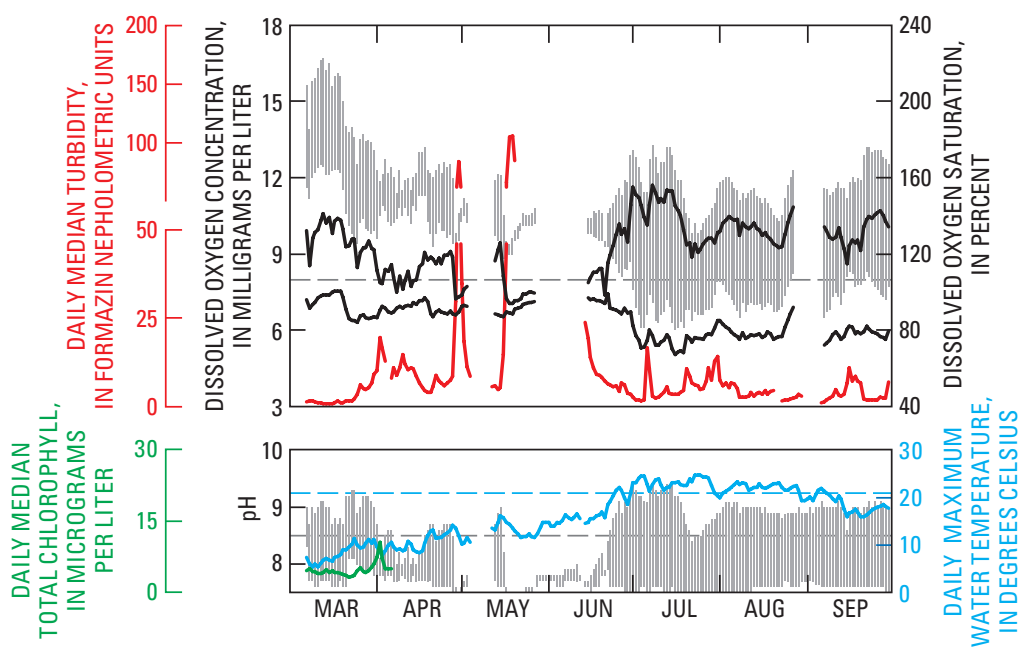

Figure 11.-Continued 

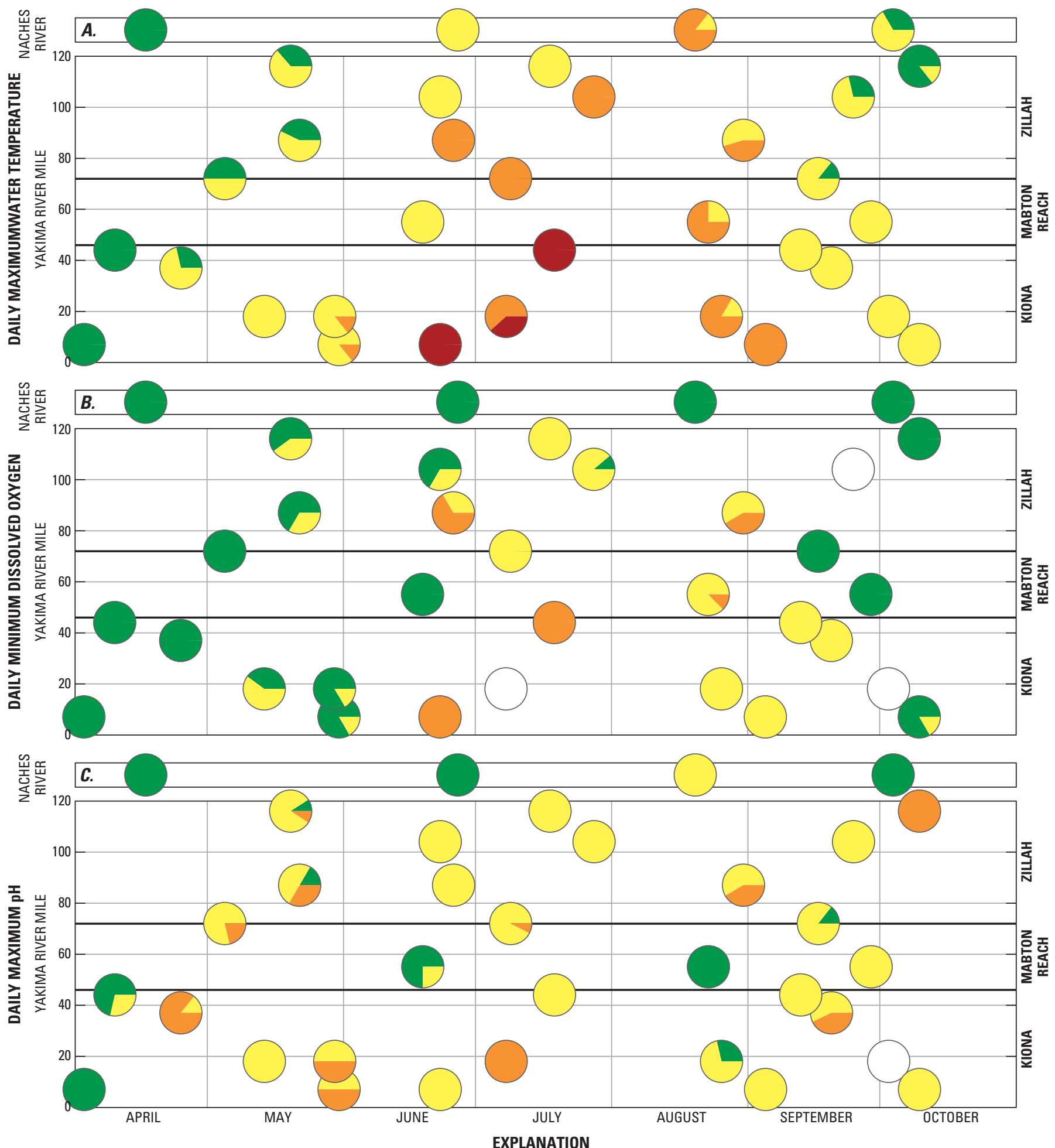

Proportion of days during deployment when:

Maximum water temperature (degrees Celsius) was:

Less than 16.0

16.0 to 21.0

21.0 to 26.0

Greater than 26.0
Minimum dissolved oxygen concentration (milligrams per liter) was:

Greater than 8.0

6.0 to 8.0 milli

4.0 to 6.0
Maximum pH was:

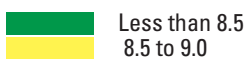

8.5 to 9.0 9.0 to 9.5
Note: Empty circles represent deployments where no data were available for dissolved oxygen and (or) $\mathrm{pH}$.

Figure 12. Summary of results from short-term continuous water-quality monitoring for $(A)$ water temperature, $(B)$ dissolved oxygen, and $(C)$ pH, Yakima and Naches Rivers, Washington, April-October 2004. 


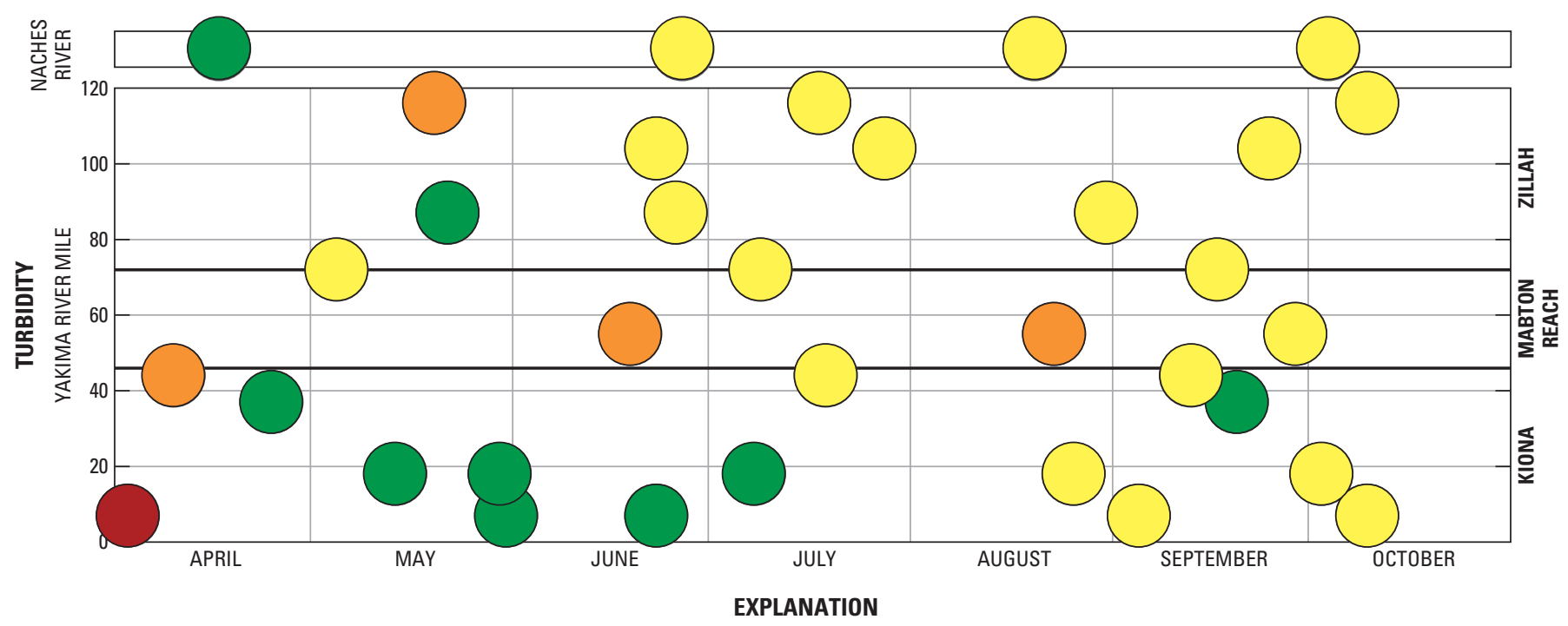

The median turbidity during the deployment was:

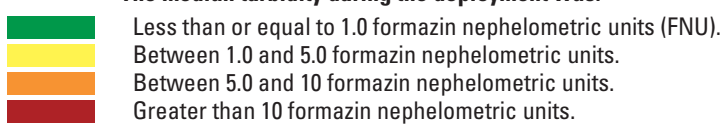

Figure 13. Summary of results from short-term continuous water-quality monitoring for turbidity, Yakima and Naches Rivers, Washington, April-0ctober 2004.

During 2004, the dissolved oxygen concentrations were greater than the Washington State standard of $8 \mathrm{mg} / \mathrm{L}$ every day during each monitor deployment in April (fig. 12B), but beginning in mid-May the daily minimum dissolved oxygen concentrations throughout the lower Yakima River were less than $8 \mathrm{mg} / \mathrm{L}$, and the concentrations were less than $6 \mathrm{mg} / \mathrm{L}$ between late June and late August from RM 87 to RM 8. In September 2004, the daily minimum dissolved oxygen concentrations were less than $8 \mathrm{mg} / \mathrm{L}$ only in the Kiona reach. The daily maximum $\mathrm{pH}$ levels were greater than the Washington State standard of 8.5 at all the stations, including the Naches River, during some periods in April through October 2004 (fig. 12C). Elevated pH levels in the Yakima River at the upstream edge of the study area (where the late season maximum values were above 9.0) and in the Naches River in August indicated that flow from upstream drainages contributed high-pH water to the lower Yakima River. The high $\mathrm{pH}$ at these locations also was partly due to the low alkalinity of the water.

\section{Kiona, Mabton, and Zillah Reaches, 2004-07}

The water temperature, dissolved oxygen concentrations, and $\mathrm{pH}$ levels in all three reaches of the lower Yakima River exceeded the Washington State standards throughout the irrigation seasons of 2004-07, but generally were most severe during the low-flow period between July 1 and September 30 of each year (table 9).

\section{Kiona Reach}

The daily maximum water temperatures at Kiona consistently were greater than the Washington State standard of $21^{\circ} \mathrm{C}$ from mid-June through early September during all 4 years (fig. 14A). The daily median turbidity values consistently were less than 5 FNU starting in mid-May 2004, March 2005, and early July 2006 and 2007 and the highest daily median turbidity values generally occurred during periods with the greatest streamflow. The water also was clearer at Kiona during summer (July 1- September 30) in 2004 and 2005 compared to 2006 and 2007-the median turbidity during summer 2004 and 2005 was 0.7 FNU, compared to $2.5 \mathrm{FNU}$ in 2006 and 2007. This result likely was partly due to the substantial differences in macrophyte abundance between years, because suspended particles are removed when water flows through macrophyte beds.

The daily minimum dissolved oxygen concentrations at Kiona were less than the Washington State standard of $8 \mathrm{mg} / \mathrm{L}$ starting in early May 2004, early April 2005, late June 2006, and mid-June 2007, and generally remained below $8 \mathrm{mg} / \mathrm{L}$ through September in all 4 years (fig. 14B). The dissolved oxygen concentrations were less than $4 \mathrm{mg} / \mathrm{L}$ in 2004 and 2005 (starting in late June and late May, respectively), but were never less than $4 \mathrm{mg} / \mathrm{L}$ in 2006 and were less than $4 \mathrm{mg} / \mathrm{L}$ on only one day in 2007. In 2004 and 2005, the daily maximum $\mathrm{pH}$ levels at Kiona were almost always greater than the Washington State standard of 8.5, whereas in 2006 and 2007 there were extended periods in the spring when the maximum daily $\mathrm{pH}$ levels were less than 8.5 (fig. 14C). 
34 Assessment of Eutrophication in the Lower Yakima River Basin, Washington, 2004-07

Table 9. Summary of water temperature, dissolved oxygen, and pH conditions in the Yakima River, Washington, March 1-June 30 and July 1-September 30, 2004-07.

[Kiona, U.S. Geological Survey (USGS) site 12510500 at RM 30; Mabton, USGS site 12509060 at RM 55; Zillah, USGS site 12505330 at RM 87. Abbreviations: $\mathrm{mg} / \mathrm{L}$, milligram per liter; -, no data]

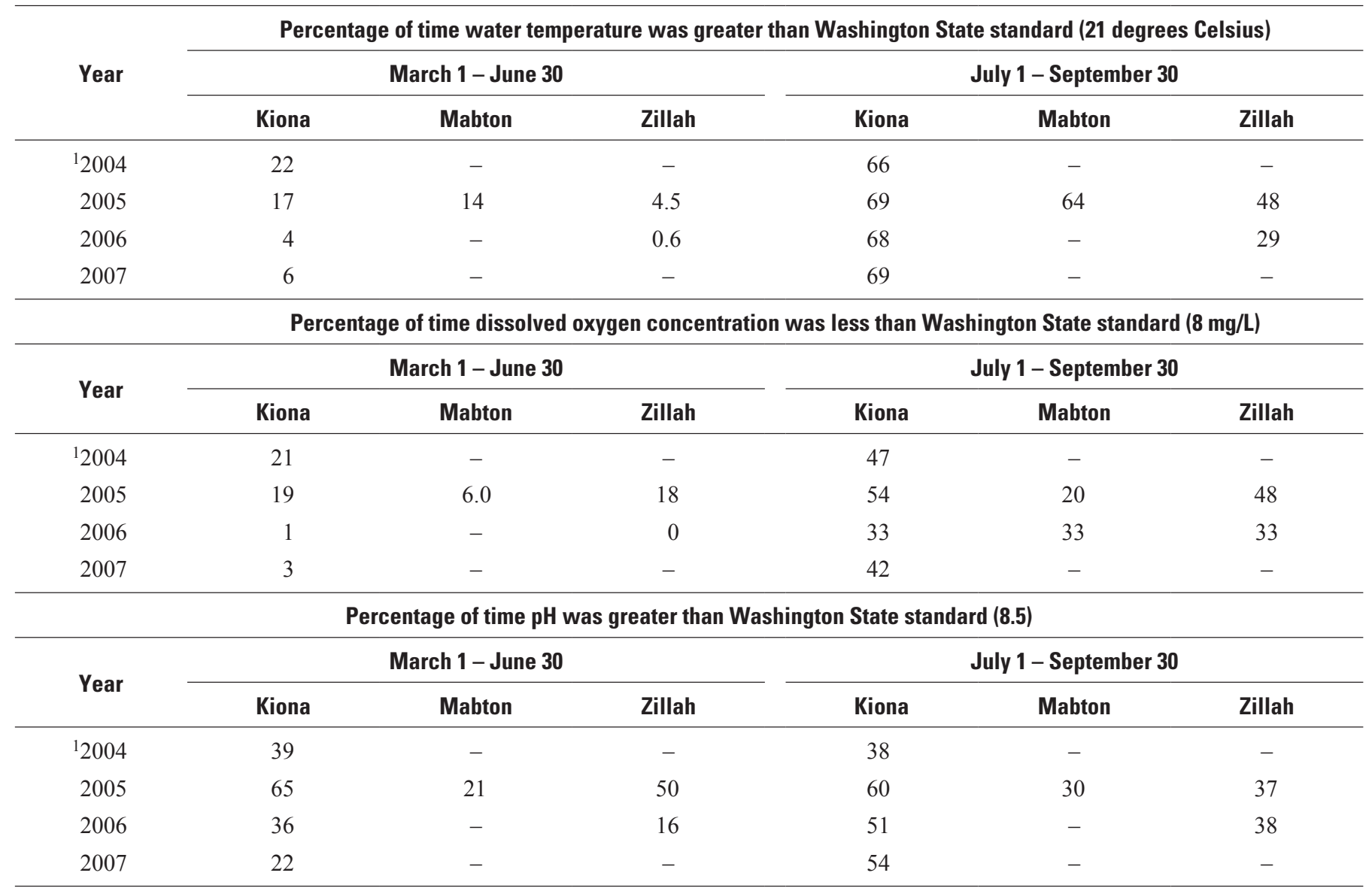

'Monitored data collection at Kiona began on April 20, 2004. 


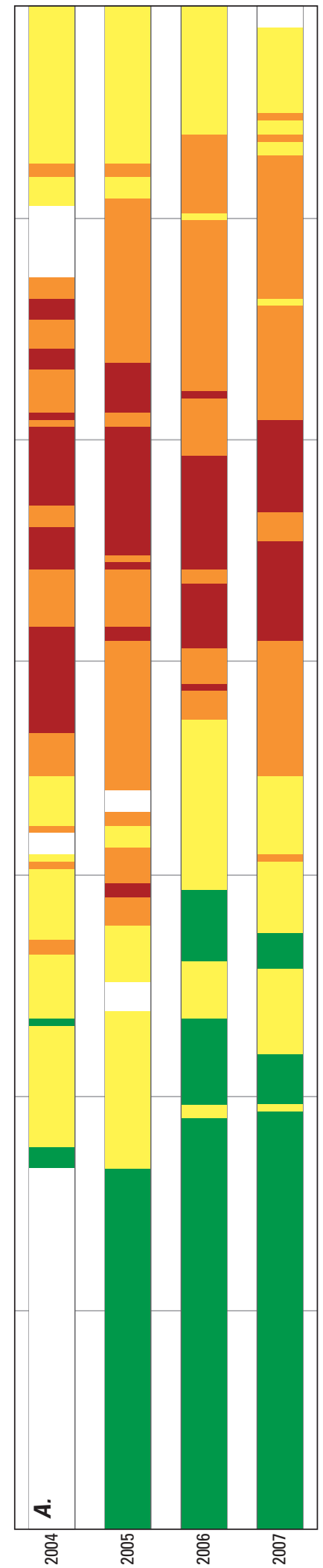

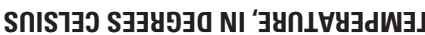
y

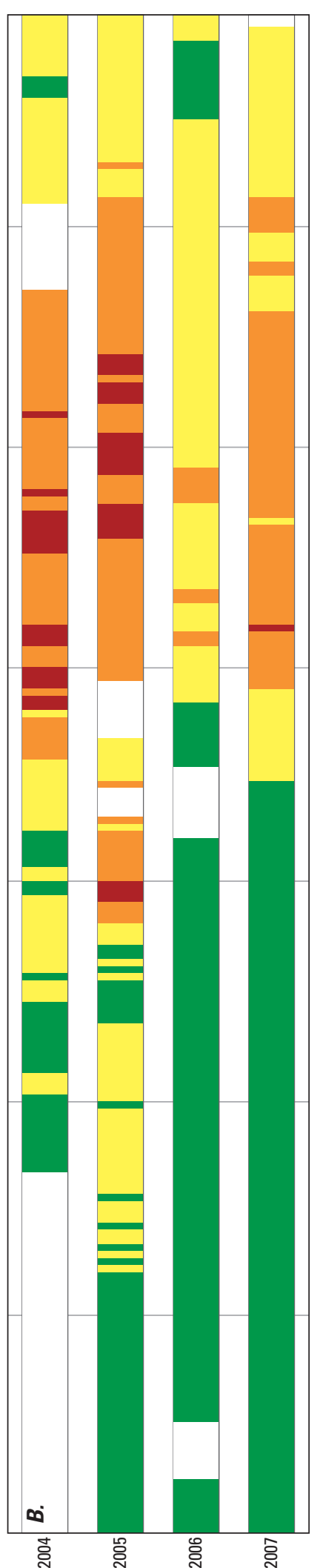

y 117 y N $39 \times X 0$

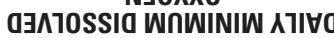

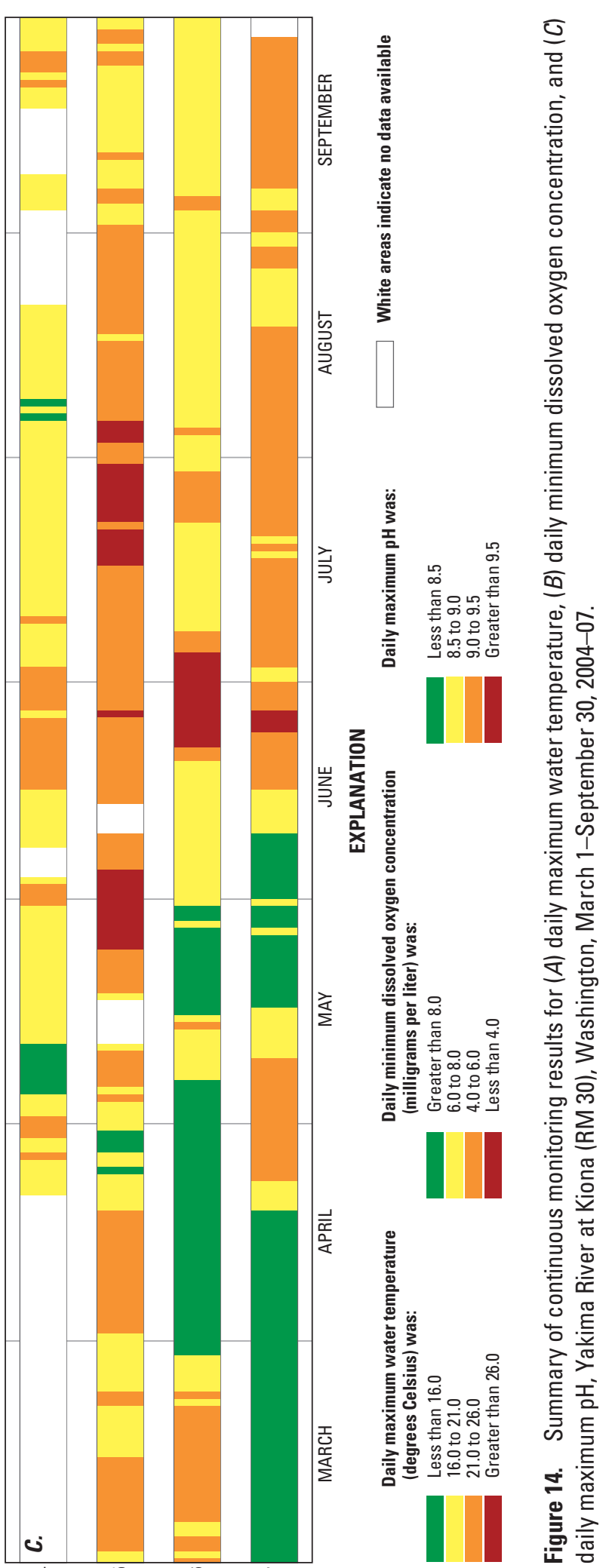

Hd WחWIX 
The dissolved oxygen concentration at Kiona was less than $8 \mathrm{mg} / \mathrm{L}$ on more than 40 percent of the days during October 2004 and 2005, but was never less than $8 \mathrm{mg} / \mathrm{L}$ between November and February during 2005-07 (table 10). The $\mathrm{pH}$ level at Kiona was greater than 8.5 on 21 to 57 percent of days in February during 2005-07 and 17 to 53 percent of days in November during 2004-06. December and January were the only months in which the $\mathrm{pH}$ level was not greater than 8.5 during any year.

\section{Zillah and Mabton Reaches}

The daily maximum water temperature was consistently above the Washington State standard of $21^{\circ} \mathrm{C}$ from mid-June through early September at Mabton and Zillah in 2005 and above $21^{\circ} \mathrm{C}$ from early July through late August at Zillah in 2006 (fig. 15A). The patterns in daily median turbidity for Zillah and Mabton were similar to those for Kionaconsistently low turbidity at both sites in 2005 and elevated turbidity values during 2006 at Zillah during periods of high flow. Some differences were noted between the three reaches, however, within the lower range of the turbidity values measured between March 1 and September 30, 2005. Although the median daily turbidity values were similar at Zillah and Kiona, the values at Mabton were greater - the median for that period at Mabton was 4.9 FNU, compared to 1.5 at Zillah and 0.7 at Kiona.

Although the daily minimum dissolved oxygen concentrations in 2005 and 2006 at Mabton and Zillah were not as low as those measured at Kiona, the values still were generally below the Washington State standard of $8 \mathrm{mg} / \mathrm{L}$ from early June through mid-August at Mabton in 2005, mid-April through September at Zillah in 2005, and early July through September at Zillah in 2006 (fig. 15B). The daily maximum $\mathrm{pH}$ levels at Zillah generally exceeded the Washington State standard of 8.5 during the entire irrigation season of 2005, but were generally below 8.5 between April and late June in 2006, after which the levels were consistently above 8.5 through September (fig. 15C). The daily maximum $\mathrm{pH}$ levels at Mabton in 2005 frequently exceeded 8.5 starting in early March, were greatest in late May (as high as 9.0), and consistently exceeded 8.5 from mid July through late September.

Table 10. Percentage of days and percentage of time when threshold values were exceeded for daily maximum water temperature, daily mean turbidity, daily minimum dissolved oxygen concentration, and daily maximum pH, Yakima River at Kiona, Washington, 2004-07.

[Threshold values for water temperature, dissolved oxygen, and $\mathrm{pH}$ are the Washington State water-quality standards for the Yakima River. Abbreviations: FNU, Formazin nephelometric units; ${ }^{\circ} \mathrm{C}$, degrees Celsius; $\mathrm{mg} / \mathrm{L}$, milligram per liter; - , no data collected; $<$, less than]

\begin{tabular}{ccccccccccccc}
\hline \multicolumn{7}{c}{ Days/time when maximum temperature was greater than $21^{\circ} \mathbf{C}$ (percent) } \\
\hline Year & January & February & March & April & May & June & July & August & September & October & November & December \\
\hline 2004 & - & - & - & $0 / 0$ & $10 / 8$ & $67 / 38$ & $100 / 55$ & $100 / 57$ & $11 / 29$ & $0 / 0$ & $0 / 0$ \\
2005 & $0 / 0$ & $0 / 0$ & $0 / 0$ & $0 / 0$ & $26 / 18$ & $89 / 55$ & $100 / 99$ & $100 / 96$ & $17 / 9$ & $0 / 0$ & $0 / 0$ & $0 / 0$ \\
2006 & $0 / 0$ & $0 / 0$ & $0 / 0$ & $0 / 0$ & $0 / 0$ & $27 / 18$ & $100 / 99$ & $100 / 90$ & $40 / 16$ & $0 / 0$ & $0 / 0$ & $0 / 0$ \\
2007 & $0 / 0$ & $0 / 0$ & $0 / 0$ & $0 / 0$ & $0 / 0$ & $60 / 24$ & $100 / 97$ & $97 / 84$ & $46 / 20$ & - & - & - \\
\hline
\end{tabular}

Days/time when minimum dissolved oxygen concentration was less than $8 \mathrm{mg} / \mathrm{L}$ (percent)

\begin{tabular}{|c|c|c|c|c|c|c|c|c|c|c|c|c|}
\hline Year & January & February & March & April & May & June & July & August & September & October & November & December \\
\hline 2004 & - & - & - & $0 / 0$ & $29 / 8$ & $96 / 38$ & $100 / 55$ & $100 / 57$ & $96 / 29$ & $43 / 8$ & $0 / 0$ & $0 / 0$ \\
\hline 2005 & $0 / 0$ & $0 / 0$ & $0 / 0$ & $63 / 17$ & $85 / 29$ & $100 / 39$ & $100 / 57$ & $100 / 58$ & $100 / 46$ & $46 / 16$ & $0 / 0$ & $0 / 0$ \\
\hline 2006 & $0 / 0$ & $0 / 0$ & $0 / 0$ & $0 / 0$ & $0 / 0$ & $19 / 5$ & $100 / 42$ & $100 / 39$ & $63 / 17$ & $6 / 2$ & $0 / 0$ & $0 / 0$ \\
\hline 2007 & $0 / 0$ & $0 / 0$ & $0 / 0$ & $0 / 0$ & $0 / 0$ & $40 / 12$ & $100 / 47$ & $100 / 43$ & $89 / 28$ & - & - & - \\
\hline
\end{tabular}

Days/time when maximum pH was greater than 8.5 (percent)

\begin{tabular}{|c|c|c|c|c|c|c|c|c|c|c|c|c|}
\hline Year & January & February & March & April & May & June & July & August & September & October & November & December \\
\hline 2004 & - & - & - & $100 / 55$ & $65 / 27$ & $100 / 46$ & $100 / 43$ & $83 / 27$ & $95 / 45$ & $48 / 18$ & $17 /<1$ & $0 / 0$ \\
\hline 2005 & $0 / 0$ & $25 / 7$ & $100 / 55$ & $87 / 66$ & $96 / 60$ & $100 / 79$ & $100 / 79$ & $100 / 58$ & $93 / 42$ & $39 / 3$ & $53 / 3$ & $0 / 0$ \\
\hline 2006 & $0 / 0$ & $21 / 5$ & $100 / 57$ & $0 / 0$ & $32 / 10$ & $97 / 78$ & $100 / 60$ & $100 / 48$ & $100 / 45$ & $100 / 25$ & $19 / 4$ & $0 / 0$ \\
\hline 2007 & $0 / 0$ & $57 / 9$ & $0 / 0$ & $40 / 21$ & $58 / 17$ & $70 / 44$ & $100 / 58$ & $100 / 52$ & $96 / 51$ & - & - & - \\
\hline
\end{tabular}

Days/time when average turbidity was greater than 20 FNU (percent)

\begin{tabular}{|c|c|c|c|c|c|c|c|c|c|c|c|c|}
\hline Year & January & February & March & April & May & June & July & August & September & October & November & December \\
\hline 2004 & - & - & - & $40 / 25$ & $0 / 0$ & $0 / 0$ & $0 / 0$ & $0 / 0$ & $0 / 0$ & $0 / 0$ & $0 / 0$ & $3 / 4$ \\
\hline 2005 & $5 / 3$ & $0 / 0$ & $0 / 0$ & 3/1 & $3 / 1$ & $0 / 0$ & $0 / 0$ & $0 / 0$ & $0 / 0$ & $0 / 0$ & $0 / 0$ & $23 / 19$ \\
\hline 2006 & $61 / 54$ & $0 / 0$ & $3 /<1$ & $44 / 46$ & $61 / 61$ & $53 / 53$ & $0 / 0$ & $0 / 0$ & $0 / 0$ & $3 / 0$ & $15 / 11$ & $6 / 8$ \\
\hline 2007 & $10 / 12$ & $14 / 13$ & $59 / 56$ & $57 / 44$ & $48 / 28$ & $20 / 17$ & $6 / 6$ & $3 / 0$ & $0 / 0$ & - & - & - \\
\hline
\end{tabular}




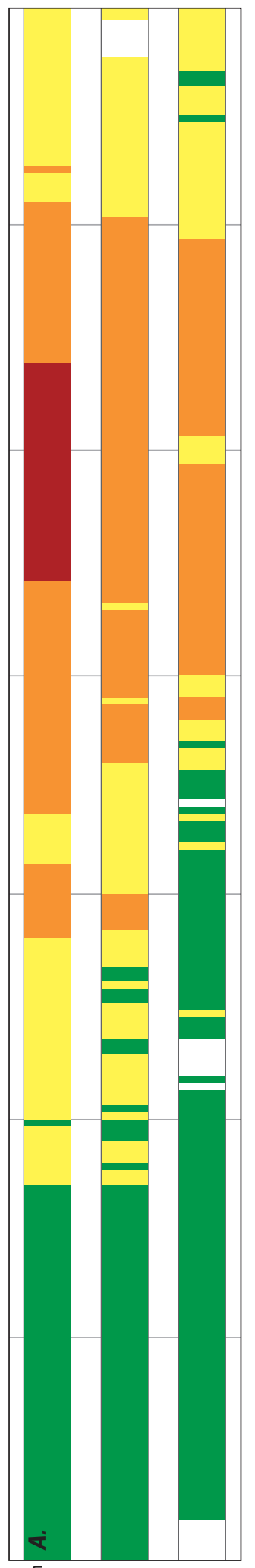

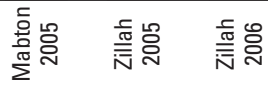

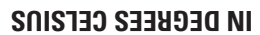

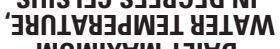
WNWIXVW AIO

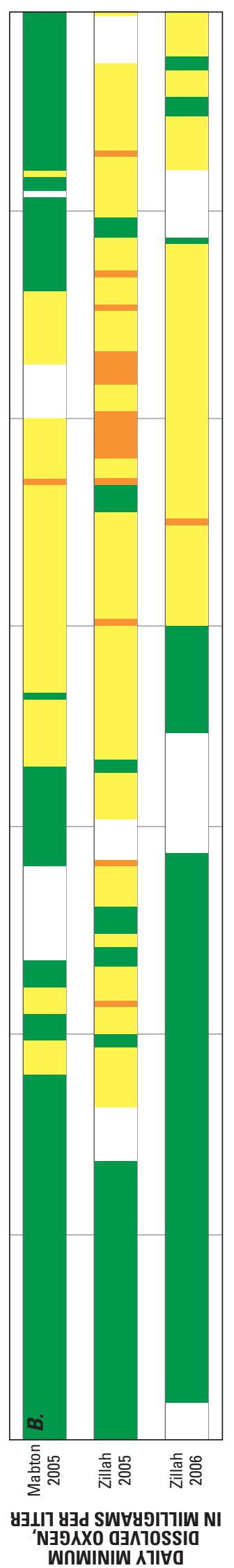

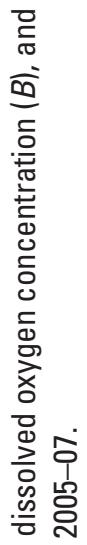

छิ
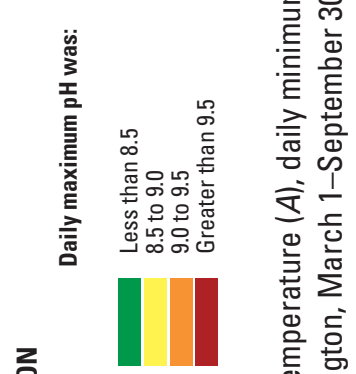

त

ळ

롫

离

官

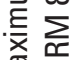

을

高

흥 둔

혹

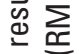
옫드

.륻

远

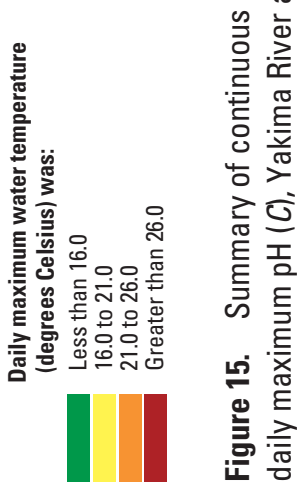




\section{Summer Results for All Reaches, 2004-07}

The mean daily maximum water temperature at Kiona and Mabton during summer (July 1-August 31) was not significantly different between years, but the mean daily maximum value was significantly less at Zillah in 2005 and 2006 than at Mabton in 2005 and at Kiona in all years (fig. 16A).Summer dissolved oxygen conditions generally were most severe at Kiona and least severe at Mabton (fig. 16B). The mean daily minimum dissolved oxygen concentration at Kiona during summer in 2004, 2005, and 2007 was significantly less than the mean daily minimum values at Zillah and Mabton during any year. The pattern in the summer $\mathrm{pH}$ conditions was similar to the pattern for dissolved oxygen - most severe at Kiona and least severe at Mabton (fig. 16C). The mean daily maximum $\mathrm{pH}$ level was not significantly different at Kiona in 2006 and 2007, between Kiona in 2006 and Zillah in 2006 and 2007, or between Kiona in 2004 and Mabton in 2005.

The mean daily minimum dissolved oxygen concentrations measured at Kiona during summer were negatively related to the level of macrophyte biomass - the lowest mean daily minimum values occurred in 2004 and 2005 when macrophyte biomass was high and the highest daily minimum mean daily values occurred in 2006 and 2007 when macrophyte biomass was low. In contrast, the mean daily maximum summer $\mathrm{pH}$ levels at Kiona were not related to the level of macrophyte biomass. Although the highest mean daily maximum $\mathrm{pH}$ level was in 2005 when macrophyte biomass was high, the lowest mean daily maximum $\mathrm{pH}$ level was in 2004 when macrophyte growth was also quite substantial (45 percent of locations surveyed in the Kiona reach during early summer 2004 were described as having abundant macrophyte growth). It is not known what caused the mean daily maximum summer $\mathrm{pH}$ value at Kiona in 2004 to be significantly lower than the mean daily maximum values in 2006 and 2007 and not significantly different from the mean daily maximum value at Mabton in 2005 (where there was generally sparse algal and macrophyte growth).

\section{Results from Reach-Scale Assessments, 2005-07}

\section{Nutrient Conditions in Zillah Reach and Naches River, 2006 and 2007, and their Relation to Periphyton Biomass}

The concentrations of DIN and SRP measured in the Zillah reach between July and October 2006 and 2007 were significantly greater than the concentrations measured in the Naches River (which were close to the method detection limits for these nutrients) (fig. 17), and measurements made in the Zillah reach during 2005-07 showed that the nutrients in the river were being supplemented by ground water inflow at certain locations. Of the 14 sites in the Zillah reach where the pore water from the hyporheic zone (area below the streambed) was sampled during 2005-07, higher nitrite plus nitrate concentrations in the pore water than in the surface water were detected at 10 sites (fig. 18A) and higher SRP concentrations in the pore water than in the surface water were detected at 12 sites (fig. 18B). Of the seven sites where the pressure difference between the surface water and pore water also was measured in the Zillah reach in 2006 and 2007, three sites showed a positive pressure difference (upwelling) and four sites showed a negative pressure difference (downwelling).

Periphyton biomass in the Zillah reach in 2006 and 2007 was not positively related to surface-water nutrient concentrations - greater biomass generally corresponded to lower nutrient concentrations (igs. 19 and 20). Although the summer nutrient concentrations in the lower Naches River generally were lower than those in the Zillah reach in 2007, the median algal biomass in the two reaches was not significantly different (fig. 9).

\section{Nutrient Uptake in the Kiona and Zillah Reaches, 2005-07}

Sampling results from this study did not show that surface-water nutrients were removed by aquatic plants in the Kiona reach. The differences between nutrient concentrations at the upstream and downstream boundaries of a $2 \mathrm{mi}$ section of the Kiona reach in July and August 2005, when the macrophyte canopy cover was estimated to be 90 percent, were less than the analytical reporting levels for the parameters that were measured. These results were not consistent with those from research in the Potomac River at the border between Maryland and Virginia, where researchers determined a 10-60 percent reduction in the water-column nitrate load over a 2 mi reach with 40-100 percent macrophyte canopy cover (primarily water stargrass) (Nancy Rybicki, U.S. Geological Survey, written commun., 2008).

Sampling results from this study showed that surfacewater nutrients likely were being removed by periphyton in the Zillah reach. Despite multiple nutrient sources in the Zillah reach, the concentrations of DIN and SRP during summer in 2006 and 2007 decreased between RM 103 and RM 87 (fig. 21). Additionally, in 5 out of 10 sets of samples, the decreases in the concentrations of DIN and SRP between the upstream and downstream sites were in proportion to the Redfield ratio (7:1). These two observations, combined with the nuisance-level periphyton growth, indicated that the longitudinal decrease in nutrients measured in the Zillah reach was due to uptake by periphyton. These results also indicated, however, that the $1.5 \mathrm{mi}$ of the Zillah reach sampled in July and August in 2005 might not have been long enough to measure longitudinal nutrient uptake. As was the case in the Kiona reach, the differences between nutrient concentrations at the upstream and downstream monitoring stations were less than the analytical reporting levels for the parameters that were measured. 

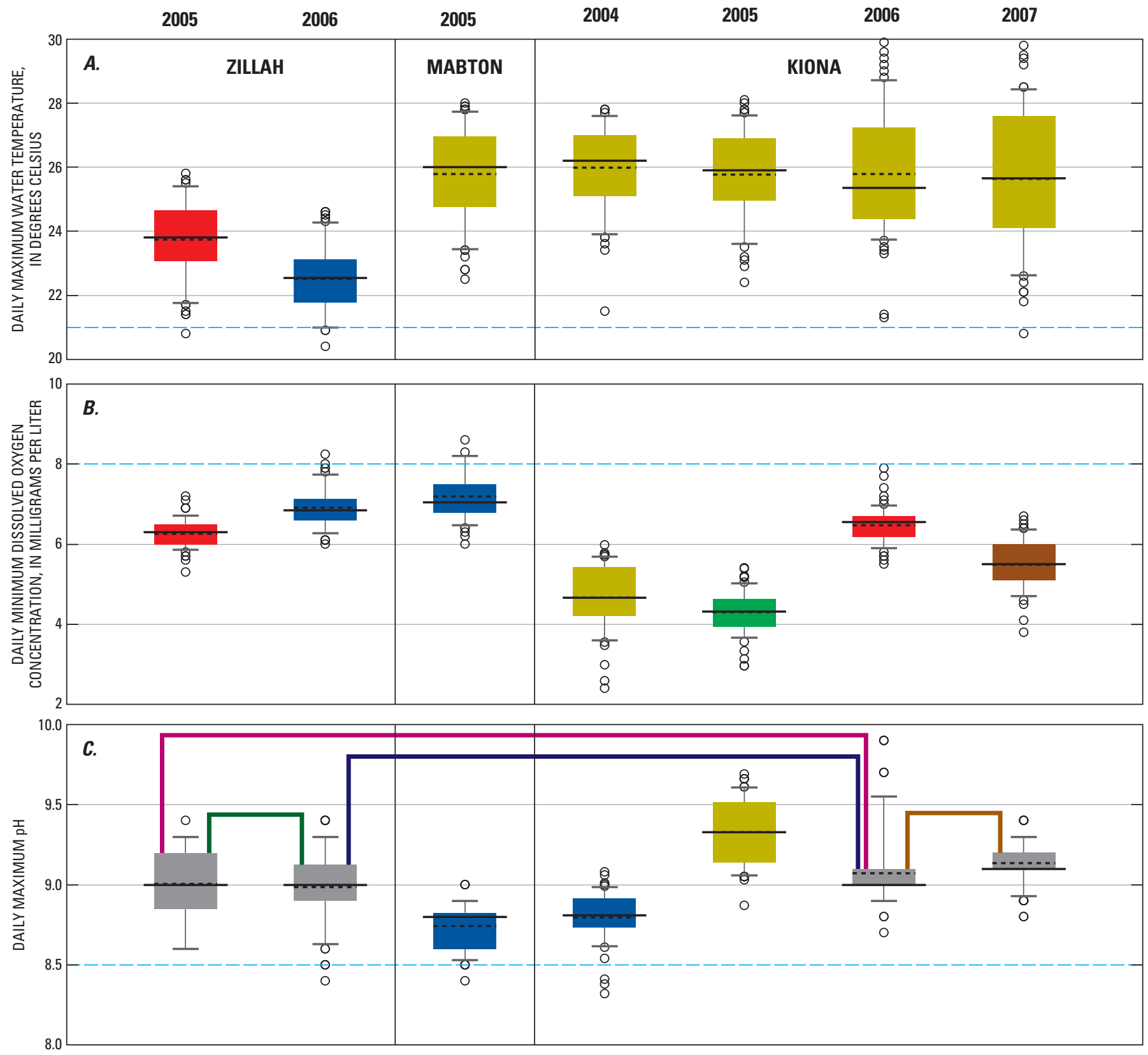

\section{EXPLANATION}

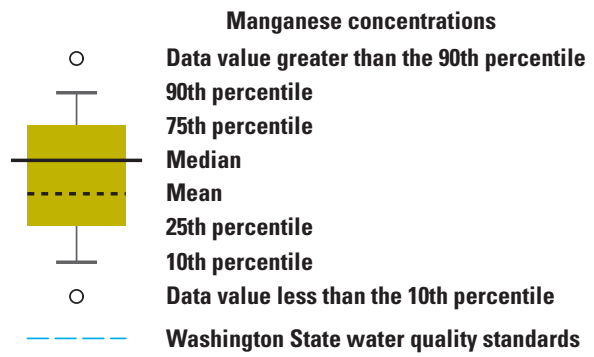

Note: The box colors indicate groups having overlapping 95 percent confidence intervals for the mean (based on the pooled standard deviation), as determined using Tukey's test. For gray boxes, the lines connect data groups with overlapping 95 percent confidence intervals for the mean.

Figure 16. Summary of $(A)$ daily maximum water temperature, $(B)$ daily minimum dissolved oxygen concentration, and $(C)$ daily maximum pH for the Yakima River at Kiona (RM 30), Mabton (RM 55), and Zillah (RM 87), Washington, July 1-August 31, 2004-07. 

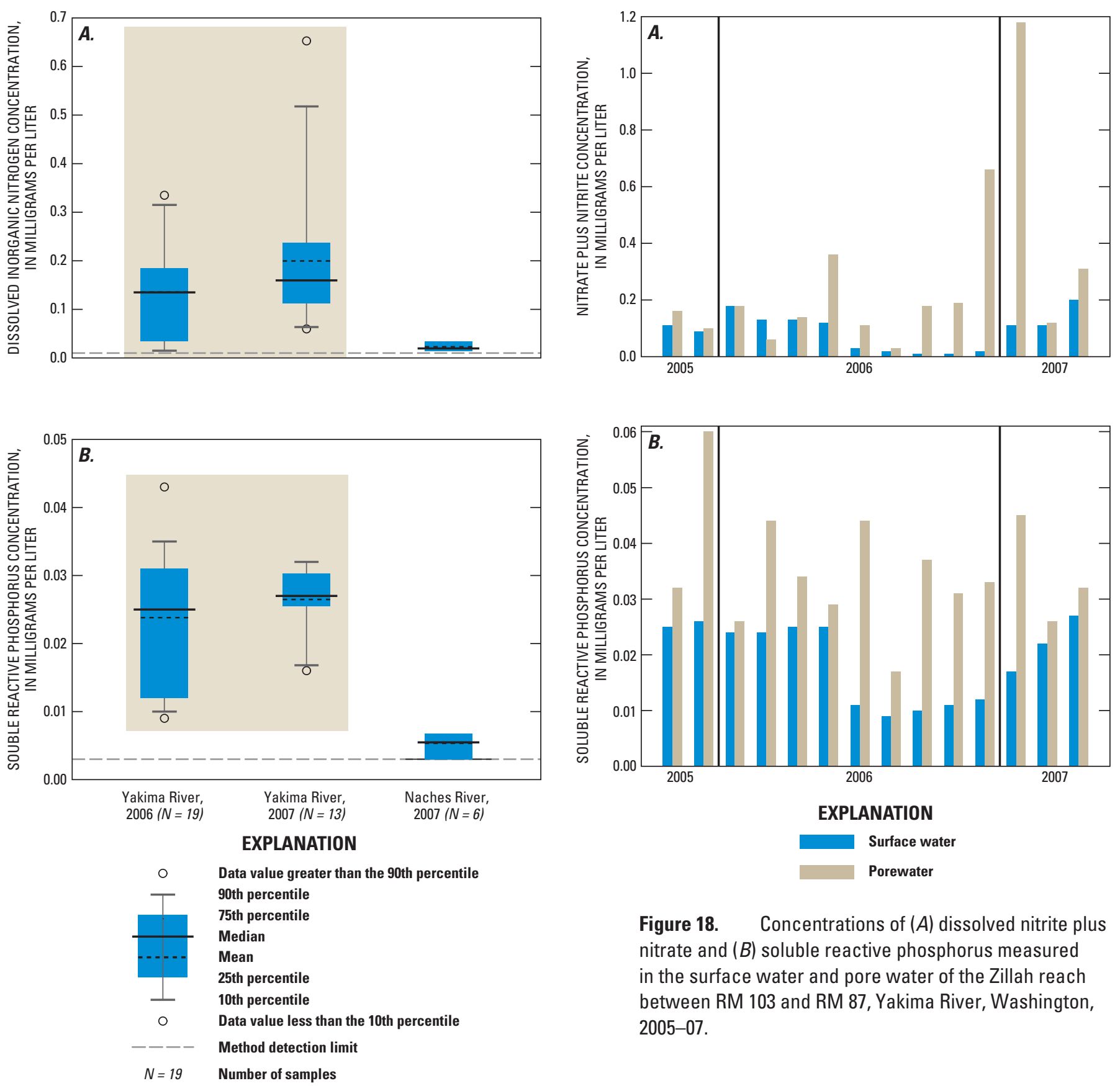

Figure 18. Concentrations of $(A)$ dissolved nitrite plus nitrate and $(B)$ soluble reactive phosphorus measured in the surface water and pore water of the Zillah reach between RM 103 and RM 87, Yakima River, Washington, 2005-07.

Notes:

Boxes enclose groups of data with overlapping 95 percent confidence intervals for the median (as determined using a pair-wise Wilcoxon signed rank comparison).

One concentration of soluble reactive phosphorus measured in the Naches River was below the method detection limit of 0.003 milligram per liter.

The method detection limit for dissolved inorganic nitrogen ( 0.01 milligram per liter) was equal to the sum of one-half the method detection limits for dissolved nitrite plus nitrate ( 0.01 milligram per liter) and dissolved ammonia (0.01 milligram per liter).

Figure 17. Concentrations of $(A)$ dissolved inorganic nitrogen and $(B)$ soluble reactive phosphorus measured in the Zillah reach of the Yakima River, between RM 103 and 87 and in the Naches River between RM 11.5 and 2.8, Washington, JulyOctober 2006-07. 

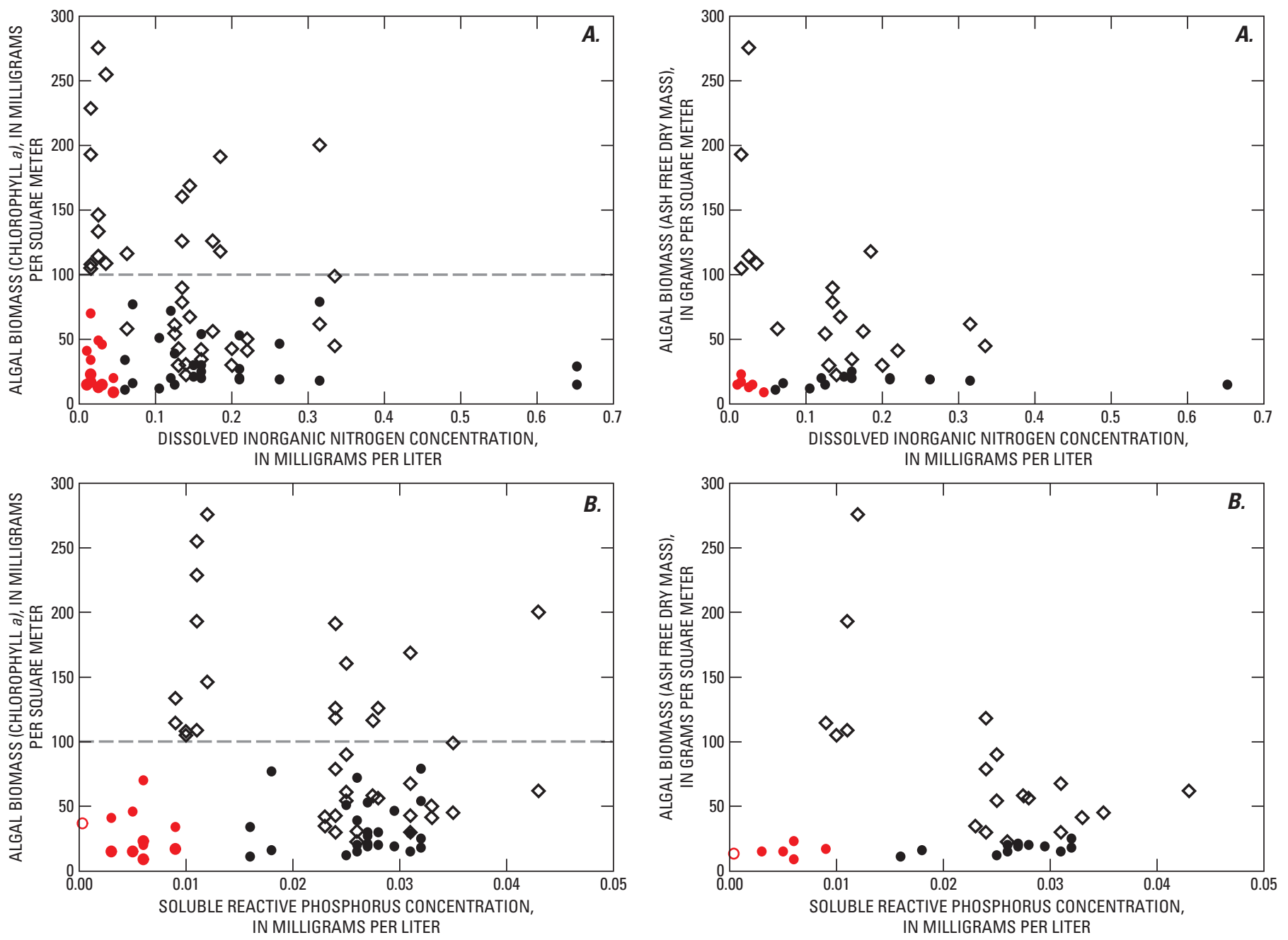

\section{EXPLANATION}

$\diamond \quad$ Results for the Yakima River in 2006

- Results for the Yakima River in 2007

- Result for the Naches River in 2007 (Empty circle indicates that the concentration was below the method detection level of 0.003 milligram per liter for soluble reactive phosphorus.)

Periphyton nuisance level established by the British Columbia Ministry of Environment (2001)

Figure 19. Relation between periphytic algal biomass (chlorophyll $a$ ) and $(A)$ dissolved inorganic nitrogen and $(B)$ soluble reactive phosphorus in the Zillah reach of the Yakima River between RM 103 and 87, July-0ctober 2006 and July-September 2007, and in the Naches River between RM 11.5 and 2.8, Washington, July-September 2007.

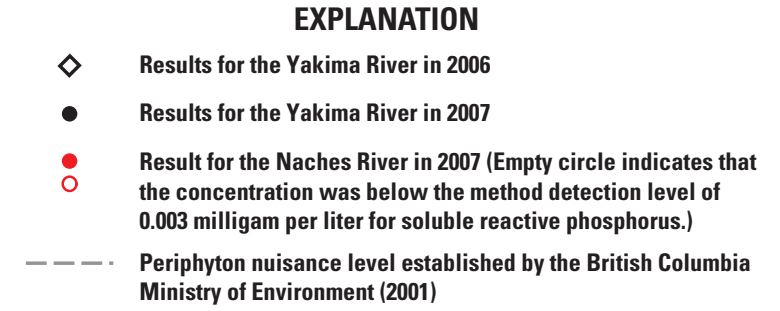

Figure 20. Relation between periphytic algal biomass (ash-free dry mass) and $(A)$ dissolved inorganic nitrogen and $(B)$ soluble reactive phosphorus in the Zillah reach of the Yakima River between RM 103 and 87, July-0ctober 2006 and July-September 2007, and in the Naches River between RM 11.5 and 2.8, Washington, July-September 2007. 

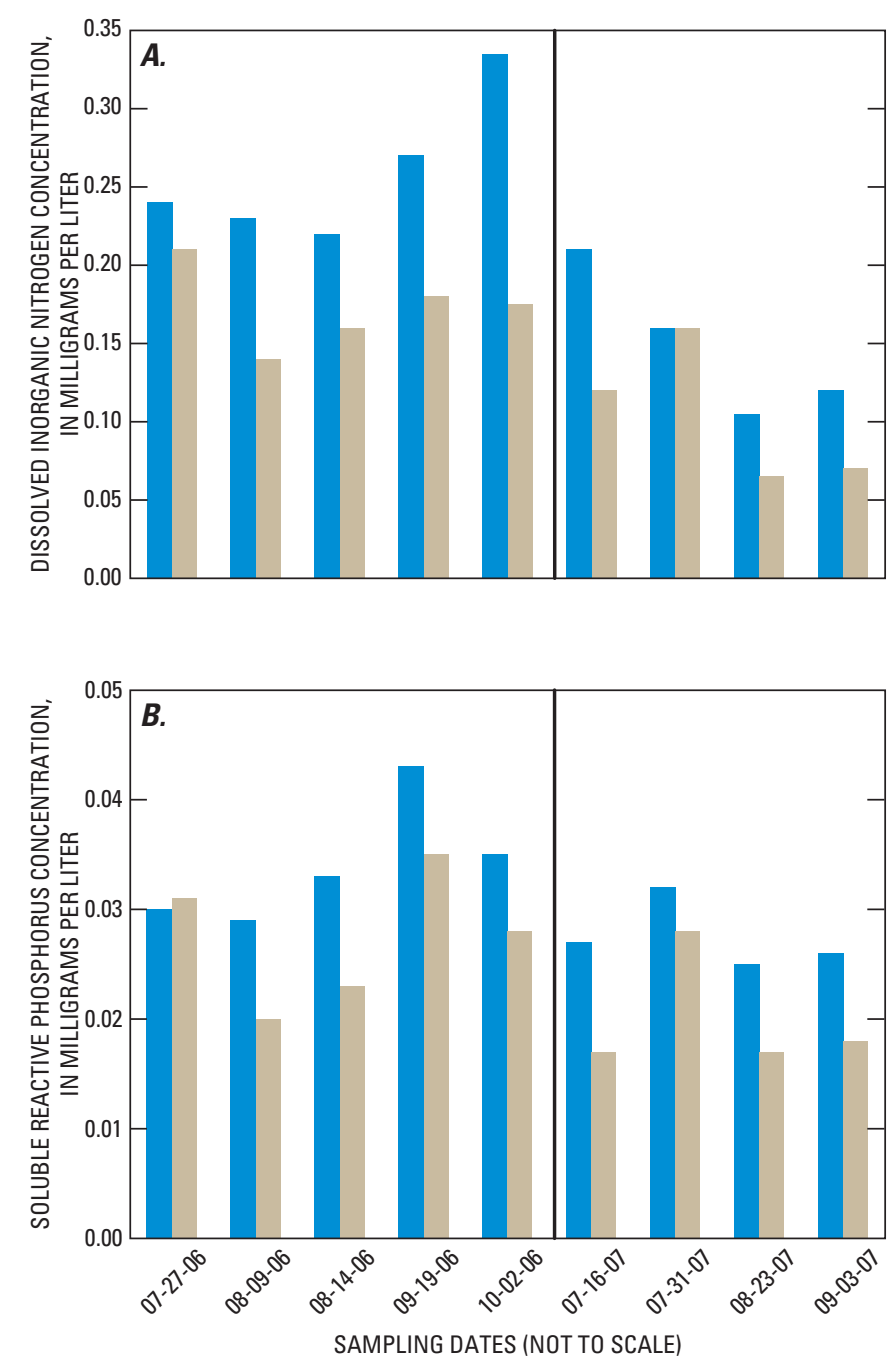

EXPLANATION

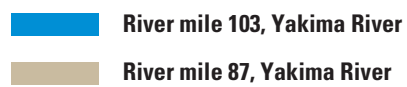

Figure 21. Concentrations of $(A)$ dissolved inorganic nitrogen and $(B)$ soluble reactive phosphorus measured in the Zillah reach at RM 103 and 87, Yakima River, Washington, July-September, 2006-07.

\section{Periphytometer Experiments in the Zillah Reach and Naches River, 2006-07}

The periphytometer results from 2006 and 2007 indicated that the Zillah reach was nutrient limited during 2 of the 11 periphytometer deployments. During July and August 2006 periphyton productivity was limited by nitrogen at RM 89. At this site, the mean control accrual rate was significantly less than the mean nitrogen-addition accrual rate (ig. 22A). The mean control accrual rate at RM 89 also was significantly less than the mean control accrual rate at RM 92. No remaining sites showed any significant difference between treatments during July and August 2006. No N plus P addition treatment was available during July and August 2006. In contrast to the July and August periphytometer deployments, the September and October 2006 deployments did not indicate any trend towards single nutrient limitation (fig. 22B ). Although mean accrual rates were similar for all treatments at any one site, the mean accrual rate was slightly greater under the addition of $\mathrm{N}$ and $\mathrm{P}$ at RM 103, indicating possible colimitation of periphyton productivity by $\mathrm{N}$ and $\mathrm{P}$. The mean control accrual rates during September and October 2006 increased downstream, with a significant increase between RM 103 and RM 87. The results from 2006 also indicated a strong seasonal production cycle for periphyton. At two of the four sites studied in 2006 the mean control accrual rates during September and October were significantly less than the mean control rates during July and August; the mean control accrual rates at the other two sites also were less (but not significantly).

The mean control accrual rates measured in the Yakima River during August and September 2007 generally were between the maximum and minimum mean control accrual rates measured in 2006 (fig. 22C). The exception was at RM 103, where the mean control accrual rate during August and September 2007 was significantly less than the mean control accrual rates at all but one of the other sites during 2006 and 2007. Mean control accrual rates in the Zillah reach increased significantly between RM 103 and RM 87 during August and September 2007, and periphyton productivity was limited by nitrogen at RM 103. The maximum mean control accrual rate in 2007 was measured at the Kiona site (RM 30). Replicate periphytometer deployments done at RM 87 during August and September 2007 showed no significant difference in mean control accrual rates between screened and unscreened experiments, indicating that the effect of grazing was not significant. The mean control accrual rate for all of the Yakima River periphytometer deployments in 2006 and 2007 was $16 \mathrm{mg} / \mathrm{m}^{2} /$ day $\mathrm{Chl} a$ with grazers excluded, which compared favorably with published rates for the Columbia River that ranged from 6 to $11 \mathrm{mg} / \mathrm{m}^{2} /$ day $\mathrm{Chl} a$ with grazers present (Cushing, 1967) and other published estimates of periphyton accrual rates ( 1 to $100 \mathrm{mg} / \mathrm{m}^{2} /$ day $\mathrm{Chl} a$ ) (Grimm and Fisher, 1986; Flipo and others, 2007).

During July and August 2007, all mean control accrual rates in the Naches River were significantly greater than the mean control accrual rate in the Zillah reach at RM 103, but not significantly different than the mean control accrual rate at RM 87, and were almost always significantly greater than the mean control accrual rates in the Zillah reach during September and October 2006 (fig. 22D). The lower Naches River also exhibited strong $\mathrm{N}$ limitation that was not observed in the Zillah reach in 2007. Comparison of the control accrual rates with the accrual rates from the $\mathrm{N}$ addition indicated that control productivity in the Naches River was at 50 percent to 60 percent of nutrient-saturated productivity. 

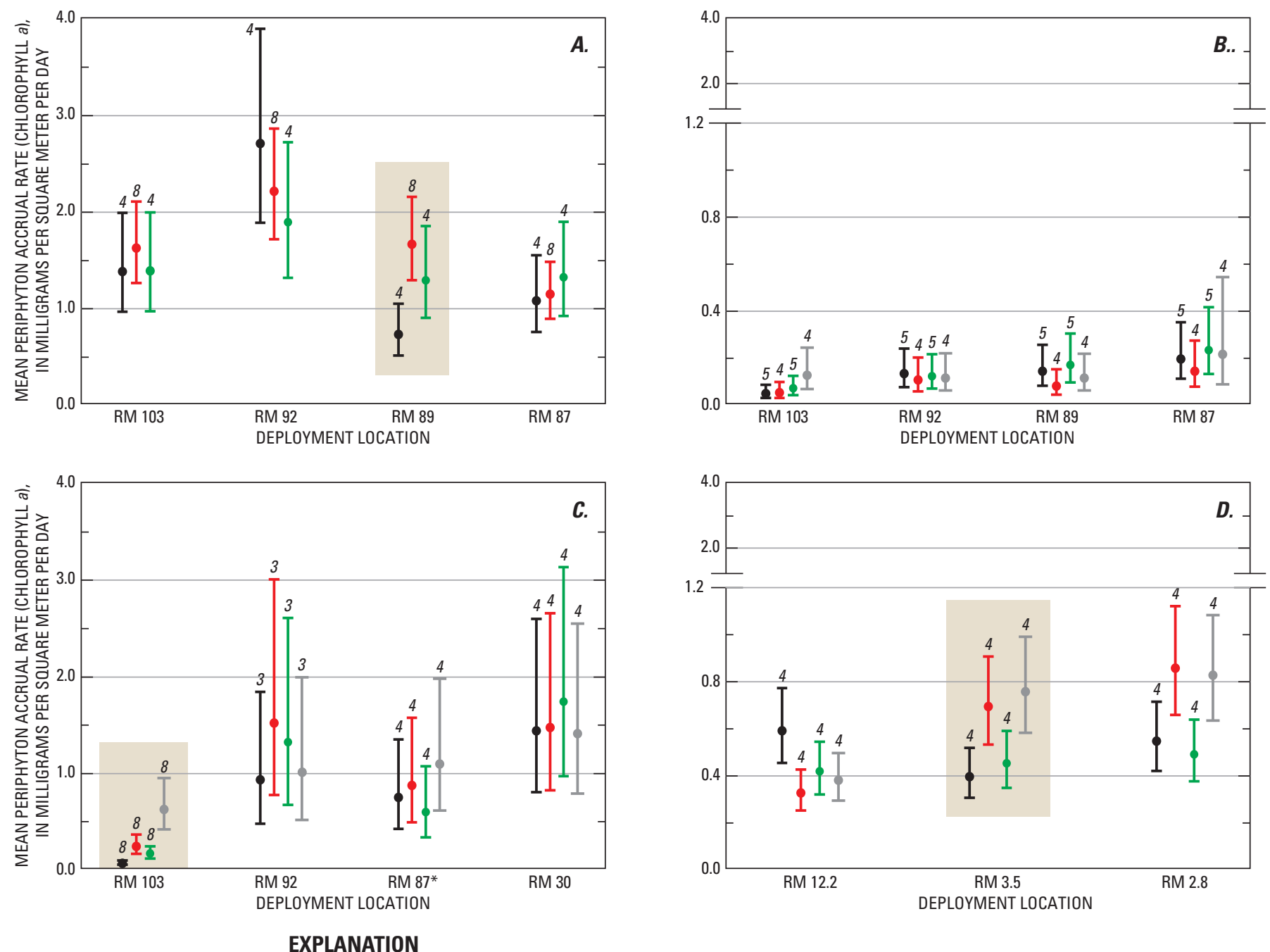

$4 \quad$ Number of samples

T Upper 95-percent confidence intervals for the mean periphyton accrual rate

Estimate of the mean periphyton accrual rate

1 Lower 95-percent confidence intervals for the mean periphyton accrual rate

- Control

- Nitrogen treatment

- Phosphorus treatment

- Nitrogen plus phosphorus treatment

Notes:

All values are geometric means.

There was no N plus $\mathrm{P}$ treatment for the July 26 - August 9, 2006 deployment.

* Substrate screens were not used during this deployment.

The boxes indicate deployments where there was a significant difference between the control and at least one of the treatments (based on the 95 percent confidence intervals).

Figure 22. Results from periphytometer experiments conducted in the Zillah reach between RM 103 and RM 87, Yakima River, (A) July 26-August 9, 2006, (B) September 19-0ctober 3, 2006, (C) August 23-September 3, 2007, and (D) in the Naches River, Washington between RM 12.2 and 2.8, August 23-September 3, 2007. 
The pattern of increasing downstream periphyton productivity in the Zillah reach in 2007 was supported by the results from the continuous water-quality monitoring conducted during the periphytometer experiments. The ranges in dissolved oxygen concentrations and $\mathrm{pH}$ (indicators of plant productivity) measured at RM 87 during the July and August, 2007 and August and September, 2007 monitor deployments were greater than the ranges measured at RM 103 (fig. 23B, C). The water temperature, dissolved oxygen concentration, and $\mathrm{pH}$ in the Zillah reach varied longitudinally during the periphytometer experiments in July and August 2006 and 2007 and generally exceeded the Washington State standards more often at the downstream locations compared with the upstream locations (table 11).

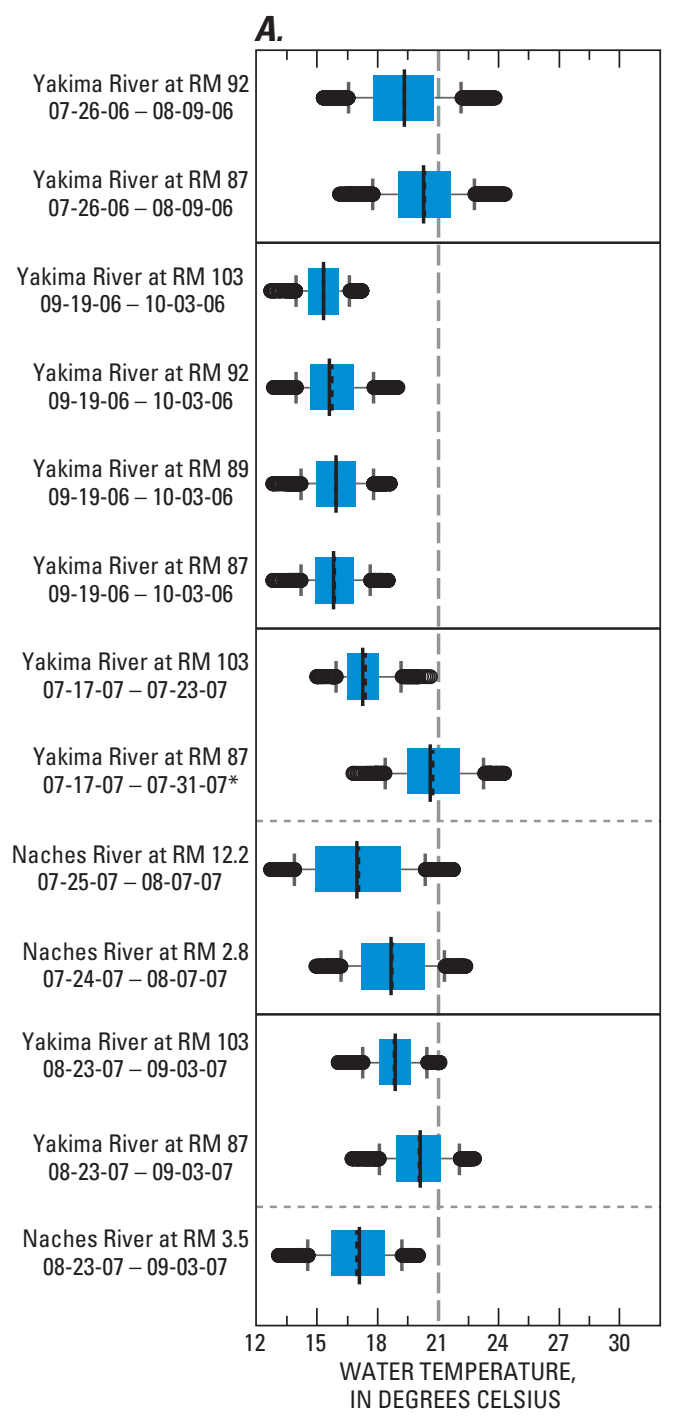

EXPLANATION

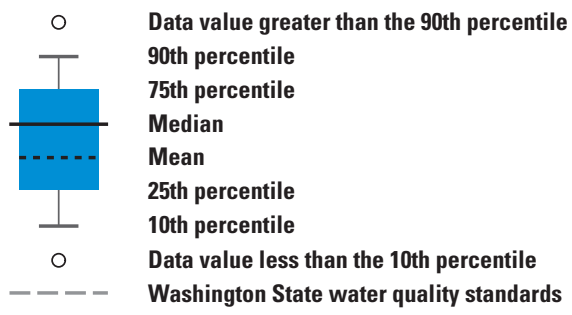

B.

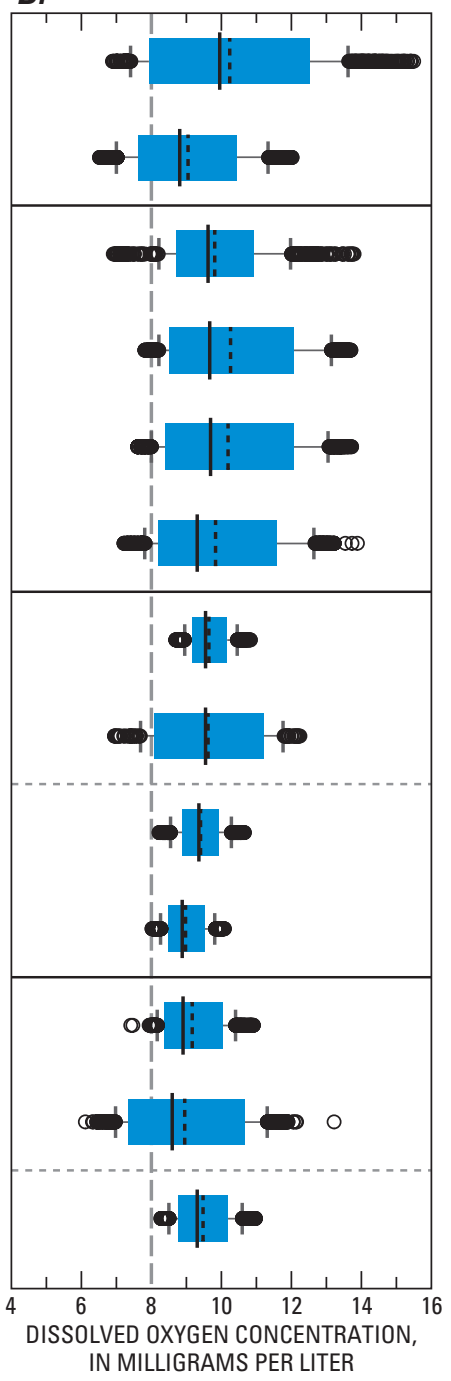

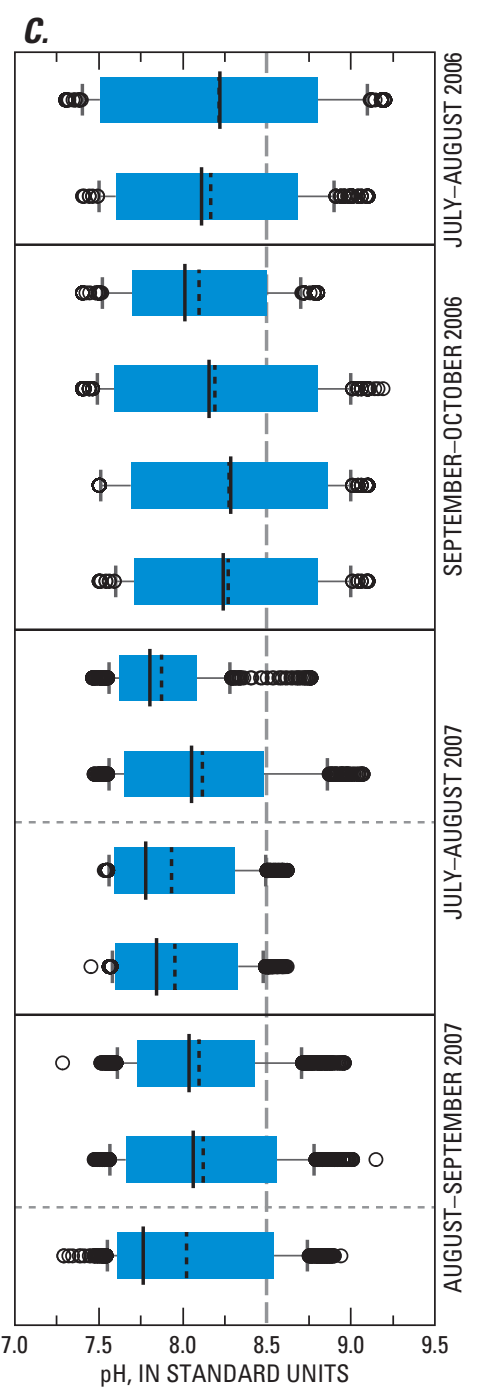

Note: The vertical dashed lines represent Washington State standards (the temperature and dissolved oxygen standards apply only to the Yakima River). *Dissolved oxygen data for this deployment extended from 7-17 to 7-23. The horizontal dashed lines separate Naches River and Yakima River deployments during the same year

Figure 23. Results from continuous water-quality monitoring during periphytometer experiments in the Zillah reach of the Yakima River, Washington between RM 103 and 87 and in the Naches River, Washington between RM 11.5 and 2.8 for $(A)$ water temperature, $(B)$ dissolved oxygen concentration, and $(C)$ pH, July 26-August 9, 2006, September 19-0ctober 3, 2006, July 17July 31, 2007, and August 23-September 3, 2007. 
Table 11. Summary of continuous water-quality monitoring for water temperature, dissolved oxygen concentration, and pH, in the Zillah reach between RM 103 and 87, Yakima River, Washington, July 26August 9, 2006, July 17-July 31, 2007, and August 23-September 3, 2007.

[Abbreviations: $\mathrm{RM}$, river mile; ${ }^{\circ} \mathrm{C}$, degrees Celsius; $\mathrm{mg} / \mathrm{L}$, milligram per liter]

\begin{tabular}{|c|c|c|c|c|}
\hline Monitoring period & Location & $\begin{array}{c}\text { Water } \\
\text { temperature } \\
\text { greater than } \\
21^{\circ} \mathrm{C} \\
\text { (percentage } \\
\text { of time) }\end{array}$ & $\begin{array}{c}\text { Dissolved } \\
\text { oxygen } \\
\text { concentration } \\
\text { less than } \\
8 \mathrm{mg} / \mathrm{L} \\
\text { (percentage } \\
\text { of time) }\end{array}$ & $\begin{array}{c}\text { pH greater } \\
\text { than } 8.5 \mathrm{pH} \\
\text { units } \\
\text { (percentage } \\
\text { of time) }\end{array}$ \\
\hline \multirow[t]{2}{*}{ July 26 - August 9, 2006} & Yakima River at RM 92 & 22 & 26 & 42 \\
\hline & Yakima River at RM 87 & 37 & 35 & 35 \\
\hline July 17 - July 23, 2007 & Yakima River at RM 103 & 0 & 0 & 5 \\
\hline July 17 - July 31, 2007 & Yakima River at RM 87 & 41 & 22 & 24 \\
\hline \multirow[t]{2}{*}{ August 23 - September 3, 2007} & Yakima River at RM 103 & 0.7 & 1.8 & 21 \\
\hline & Yakima River at RM 87 & 29 & 41 & 29 \\
\hline
\end{tabular}

\section{Gross Primary Productivity in the Kiona and Zillah Reaches, 2005-07}

The median spring (March 1-June 30) GPP value at Kiona in 2005 was significantly greater by 4 times than the median values in 2006 and 2007 (fig. 24A). Spring 2005 was a period of extremely low streamflow for the Yakima River compared to historical conditions, whereas spring 2006 and 2007 were periods of average streamflow compared to historical conditions. The differences between spring GPP in the Kiona reach between years was consistent with the pattern in macrophyte biomass measured in late summer $\left(1,020 \mathrm{~g} / \mathrm{m}^{2}\right.$ in $2005,32 \mathrm{~g} / \mathrm{m}^{2}$ in 2006 , and $84 \mathrm{~g} / \mathrm{m}^{2}$ in 2007).

The median summer (July 1-August 31) GPP value at Kiona in 2005 was significantly greater than the median summer GPP values at Zillah in 2005 and at Kiona in 2006 and 2007 (fig. 24B). In contrast to the spring GPP values for Kiona, however, the difference between the median summer GPP value at Kiona in $2005\left(21.7 \mathrm{~g} / \mathrm{m}^{2} / \mathrm{d}\right)$ and the median values in 2006 and 2007 (19.6 and $18.0 \mathrm{~g} / \mathrm{m}^{2} / \mathrm{d}$, respectively) were not consistent with the large differences between macrophyte biomass measured during those years.

The net summer primary productivity (see text box on primary productivity) at Kiona and Zillah was consistently around zero in 2005, meaning that there was generally a balance between the formation and consumption of organic matter in those reaches (the carbon produced by the autrophic organisms during daytime photosynthesis was in balance with carbon consumed by the heterotrophic organisms during respiration). In contrast, the net summer primary productivity at Kiona was consistently positive in 2006 and 2007, meaning that there was generally a net gain of organic matter in that reach (the autotrophic organisms were producing more carbon than was being consumed by the heterotrophic organisms).

\section{Evaluation of Light Availability in the Kiona Reach, 2005-07}

Sufficient light was available for macrophyte growth in the Kiona reach during most of the spring and summer during 2005, but only during the summer during 2006 and 2007. Between late April and late August 2005 and between late June and late August 2006 and 2007, the maximum depths of plant colonization were equal to or greater than the water depth at the Kiona gaging station (fig. 25), which represented the mean depth of much of the reach-indicating that there was sufficient light for macrophyte growth in the reach. In contrast, between early April and mid-June 2006, the maximum depths of plant colonization were less than the water depths at the Kiona gaging station - indicating that light was not sufficient for macrophyte growth in the reach. Only one estimate of the maximum depth of plant colonization was made during the spring runoff period in early June 2007 and this value also was less than the water depth at the Kiona gaging station at that time.

A comparison between the maximum depth of plant colonization and turbidity indicated that a turbidity threshold may have existed above which macrophyte growth was suppressed because of a lack of adequate light. When the turbidity was less than $10 \mathrm{FNU}$ the corresponding maximum depth of plant colonization varied greatly (ranging from 2 to $22 \mathrm{ft}$ ), but when the turbidity was greater than $15 \mathrm{FNU}$ the maximum depth of plant colonization was always less than $6 \mathrm{ft}$ (ig. 26). 

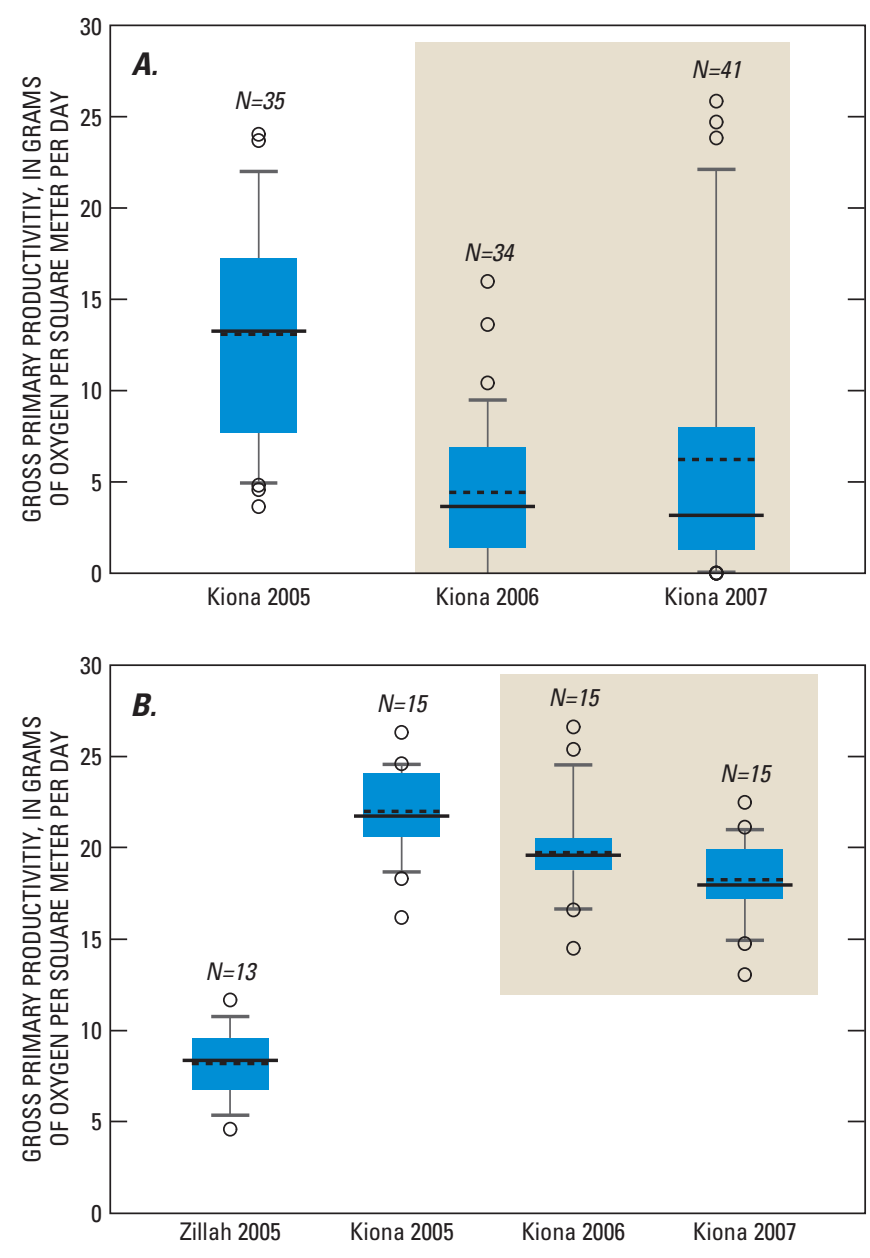

EXPLANATION

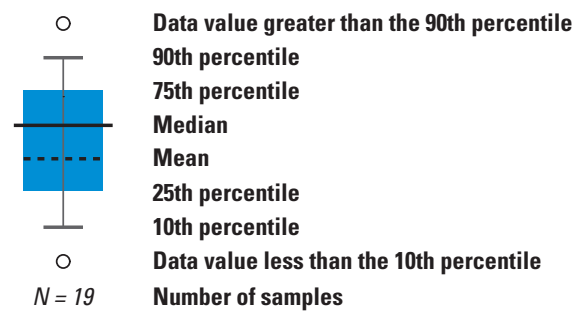

Note: The boxes enclose groups of data having overlapping 95 percent confidence intervals for the median (as determined using a pair-wise Wilcoxon signed rank comparison)

Figure 24. Summary of daily estimates of gross primary productivity for (A) Yakima River at Kiona (RM 30), Washington, March 1-June 30, 2005-07 and (B) Yakima River at Zillah (RM 87) and Kiona (RM 30), Washington, July 1-August 30, 2005-07.
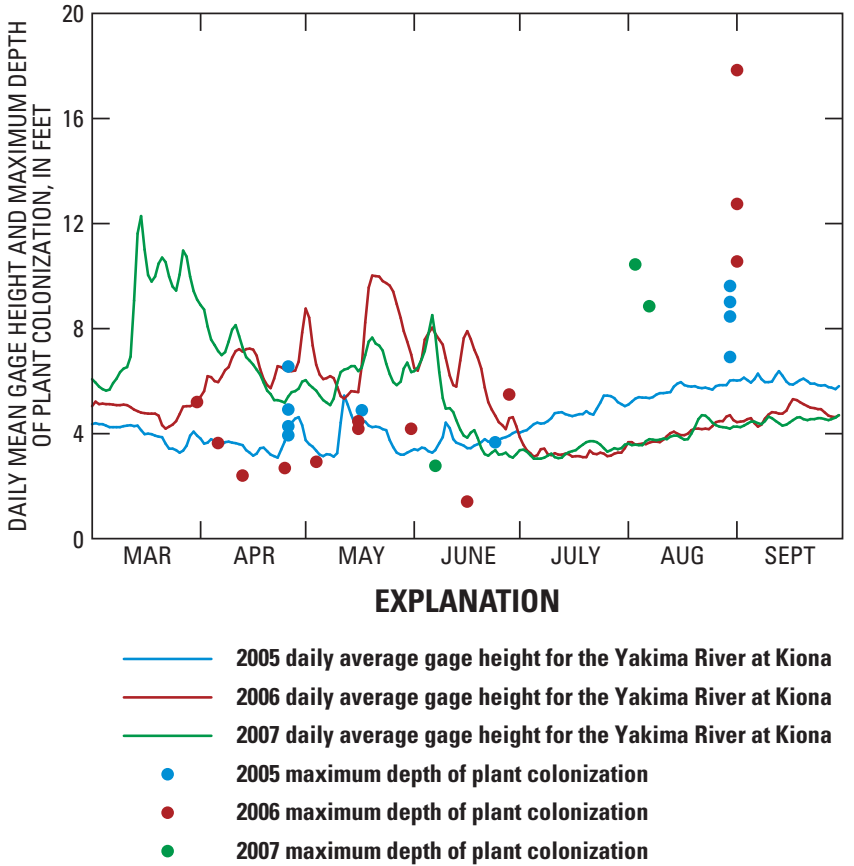

Note: Values for maximum depth of plant colonization that are equal to or greater than the gage height indicate that sufficient light was available for macrophyte growth.

Figure 25. Daily mean gage height and maximum depths of plant colonization estimated at RM 30 and RM 20, Yakima River, Washington March 1-September 30, 2005-07.

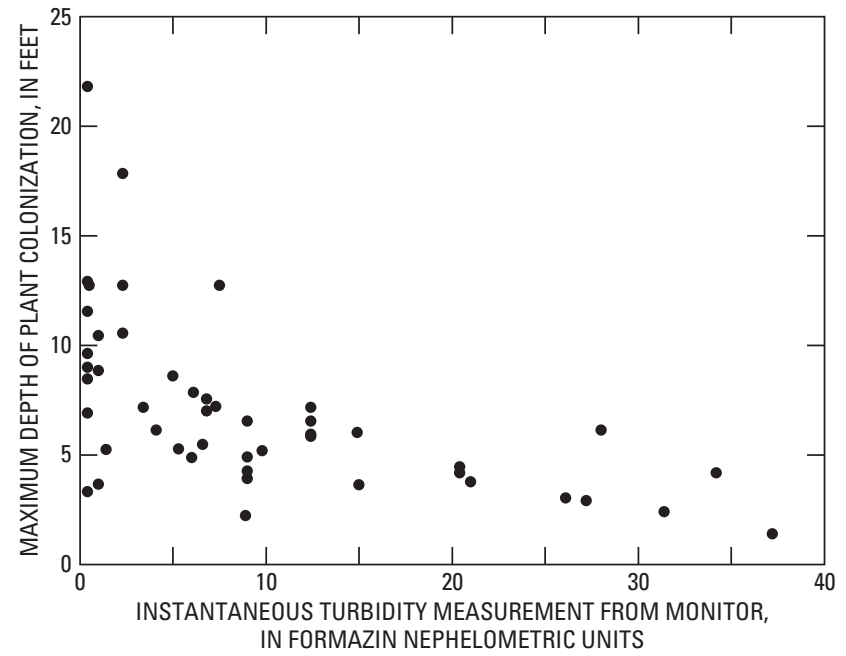

Vertical line on plot shows break at 15 FNU between large scatter in values for maximum depth to plant colonization and

consistently low values for the parameter. Maximum depth of plant colonization estimated from water column light extinction measurements of photosynthetically-active radiation.

Figure 26. Estimated maximum depths of plant colonization and instantaneous turbidity between RM 116 and RM 8, Yakima River, and between RM 12 and RM 3.5, Naches River, Washington, March 1-September 30, 2005-07. 


\section{Discussion of Results}

The results from this study showed that concentrations of nutrients in the entire lower Yakima River were high enough at certain times and places to support the abundant growth of phytoplankton, periphyton, and macrophytes and that the metabolism associated with this plant growth caused exceedences of the Washington State water-quality standards for dissolved oxygen and $\mathrm{pH}$. The abundance and distribution of these aquatic plants, however, varied greatly throughout the lower river and, in the case of macrophytes, between years.

\section{Comparison of Nutrient and Algal Biomass Conditions to Suggested Criteria}

The comparison of nutrient and algal biomass conditions to suggested criteria were based on samples collected between July 1 and September 30, 2004-07. All concentrations of dissolved nitrite plus nitrate and total nitrogen measured in the Mabton and Kiona reaches were greater than the suggested USEPA reference conditions. In contrast, the concentrations of dissolved nitrite plus nitrate and total nitrogen measured in the Zillah reach often were less than the reference conditions and the mean concentrations of these nutrients measured in the Zillah reach were much closer to the reference conditions compared to the Mabton and Kiona reaches (table 12). Although all concentrations of total phosphorus measured in the Kiona, Mabton, and Zillah reaches were greater than the reference conditions, the mean concentration measured in the Zillah reach was much closer to the reference condition compared to the Mabton and Kiona reaches. One-quarter or less of concentrations of dissolved nitrite plus nitrate, TKN, and total nitrogen, and one-half of concentrations of total phosphorus measured in the Naches River, were greater than the reference conditions and the mean concentrations of all four nutrients were less than the reference conditions.

Twelve percent of the phytoplankton $\mathrm{Chl} a$ concentrations measured in the Yakima River and no phytoplankton Chl $a$ concentrations measured in the Naches River were greater than the State of Oregon nuisance level of $15 \mu \mathrm{g} / \mathrm{L}$. Thirtynine percent of the periphyton biomass samples in the Zillah reach, but no periphyton biomass samples in the Naches River or the single periphyton biomass sample in the Kiona reach were greater than the Province of British Columbia nuisance level of $100 \mathrm{mg} / \mathrm{m}^{2}$ (table 12 ).

The mean concentrations of nitrite plus nitrate, total nitrogen, and total phosphorus measured by WA DOE in the Zillah reach (Washington State Department of Ecology, 2008 b) were less than the concentrations of nutrients measured in the reach for this study and, unlike the concentrations measured in this study, were close to or less than the reference conditions (table 12). This was most likely because the WA DOE samples were collected at a fixed station (RM 111) upstream of major nutrient inputs to the river-the City of Yakima wastewater treatment plant, Wide Hollow Creek, Moxee Drain, and Ahtanum Creek, which together contributed about 33 percent the total nitrogen load and 47 percent of the total phosphorus load that entered the Zillah reach during the 2004 synoptic survey, whereas almost all samples for this study were collected downstream of these inputs.

Table 12. Comparison of nutrient and algal biomass results to suggested U.S. Environmental Protection Agency reference conditions and algal biomass nuisance levels for the lower Yakima and Naches Rivers, July 1-September 30, $2004-07$.

[Suggested reference conditions are from U.S. Environmental Protection Agency (2000b). Shading indicates values greater than the suggested U.S. Environmental Protection Agency reference conditions. Phytoplankton nuisance level established by the State of Oregon (Oregon Administrative Code, 2006). Periphyton nuisance level established by the Province of British Columbia (British Columbia Ministry of Environment, 2001). Zillah-WADOE, results from sampling done by the Washington State Department of Ecology at Nob Hill (RM 111). Abbreviations: RM, river mile; num, number of samples collected; per, percentage of values greater than reference condition or nuisance level; med, median value for all samples; $\mathrm{mg} / \mathrm{L}$, milligram per liter; $\mu \mathrm{g} / \mathrm{L}$, microgram per liter; $\mathrm{mg} / \mathrm{m}^{2}$, milligram per square meter; -, no data]

\begin{tabular}{|c|c|c|c|c|c|c|c|c|c|c|c|c|c|c|c|c|c|c|}
\hline \multirow{3}{*}{ Reach } & \multicolumn{12}{|c|}{ Suggested USEPA reference condition } & \multicolumn{6}{|c|}{ Nuisance level } \\
\hline & \multicolumn{3}{|c|}{$\begin{array}{c}\text { Nitrate plus nitrite } \\
\text { as nitrogen } \\
(0.072 \mathrm{mg} / \mathrm{L})\end{array}$} & \multicolumn{3}{|c|}{$\begin{array}{l}\text { Total Kjeldahl } \\
\text { nitrogen } \\
\text { (0.288 mg/L) }\end{array}$} & \multicolumn{3}{|c|}{$\begin{array}{l}\text { Total nitrogen } \\
\text { (0.221 mg/L) }\end{array}$} & \multicolumn{3}{|c|}{$\begin{array}{l}\text { Total phosphorus } \\
(0.030 \mathrm{mg} / \mathrm{L})\end{array}$} & \multicolumn{3}{|c|}{$\begin{array}{c}\text { Phytoplankton } \\
\text { chlorophyll a } \\
(15 \mu \mathrm{g} / \mathrm{L})\end{array}$} & \multicolumn{3}{|c|}{$\begin{array}{l}\text { Periphyton } \\
\text { chlorophyll a } \\
\left(100 \mathrm{mg} / \mathrm{m}^{2}\right)\end{array}$} \\
\hline & num & per & mean & num & per & mean & num & per & mean & num & per & mean & num & per & med & num & per & med \\
\hline Naches River & 12 & 25 & 0.031 & 12 & 8 & 0.135 & 12 & 17 & 0.166 & 12 & 50 & 0.032 & 2 & 0 & 1.5 & 6 & 0 & 44 \\
\hline Zillah-WADOE (RM 111) & 12 & 58 & 0.095 & - & - & - & 12 & 33 & 0.201 & 12 & 50 & 0.030 & - & - & - & - & - & - \\
\hline Zillah (RM 116-72) & 87 & 79 & 0.317 & 79 & 9 & 0.197 & 86 & 79 & 0.478 & 80 & 100 & 0.059 & 21 & 14 & 4.6 & 36 & 37 & 80 \\
\hline Mabton (RM 72-47) & 11 & 100 & 1.095 & 11 & 82 & 0.373 & 11 & 100 & 1.468 & 11 & 100 & 0.144 & 20 & 20 & 13 & 0 & - & - \\
\hline Kiona (RM 47-4) & 22 & 100 & 0.875 & 20 & 25 & 0.256 & 22 & 100 & 1.108 & 20 & 100 & 0.140 & 16 & 6 & 4.4 & 1 & 0 & 8 \\
\hline
\end{tabular}




\section{Factors Related to Periphyton Biomass}

The lack of a positive relation between surface-water nutrient concentrations and algal biomass in the Zillah reach could mean that nutrients were being removed from the water by algae or that physical factors and (or) grazing by invertebrates, rather than nutrient concentrations, were controlling algal growth. The shallow and relatively wide channel in the Zillah reach may have provided a large amount of habitat favorable for algal growth where light was available for photosynthesis. Moderate-to-high water velocities in this reach may have favored enhanced growth by delivering nutrients or removing waste products at higher rates (Horner and others, 1983; Stevenson, 1997). Higher water velocities, however, result in increased drag on algal cells, which can reduce biomass (Stevenson, 1997). This may explain the higher biomass observed along the stream margins in the Zillah reach, where the water velocity was less than in the main current.

The lack of a positive relation between surface-water nutrient concentrations and algal biomass in the Zillah reach also could have been due to the complicating effect of ground water. The paired pore water and surface water nutrient and hydraulic measurements in the Zillah reach in 2006 and 2007 showed that the infusion of nutrient-rich ground water may have stimulated periphyton growth in some sections of this reach. These results are consistent with the findings of other regional studies. According to Kinnison and Sceva (1963), “A large amount of subsurface return flow from irrigation enters the river between this station (Yakima River near Mabton at RM 55) and the next upstream at Parker (RM 104)." Previous studies measured nitrate concentrations between 1 and $5 \mathrm{mg} / \mathrm{L}$ in about 250 of nearly 500 wells sampled in the watershed for Toppenish Creek (which enters the Zillah reach at RM 80), with nitrate concentrations from a few wells reaching 5-10 mg/L (Sumioka, 1998).

Results from the 2004 synoptic survey indicated that regional ground water likely was supplying nutrients to the Zillah reach. The nitrogen load from the small irrigation return drains between RM 86 and 83 could not account for the sudden increase in the concentration of dissolved nitrite plus nitrate between these two locations. The sudden increase could have been caused, however, by upwelling of nutrientrich ground water related to the regional geology. The lower Yakima River basin consists of a series of troughs and ridges that run perpendicular to the river. The river generally loses water at the upper ends of these troughs and gains ground water at the lower ends. The Yakima River gains water between RM 85 and RM 81, where Toppenish Ridge and Snipes Mountain (which are part of the same formation) intersect the river and form the lower end of one of these troughs. Some of this gain can be attributed to the release of ground water from the alluvial aquifer as it pushes up against the bedrock outcrop running along the northeast side of the river in this area (John Vaccaro, U.S. Geological Survey, written commun., 2008).

\section{Factors Related to Macrophyte Biomass}

The most prolific macrophyte in the lower Yakima River was, by far, water stargrass, especially downstream of Prosser Dam at RM 47. This plant is found throughout the United States (Horn, 1983; Smart and others, 2005) and is native to Washington State. Although its great abundance in the lower Yakima River poses a nuisance at times by interfering with recreation and contributing to low dissolved oxygen concentrations and high $\mathrm{pH}$, moderate amounts of water stargrass provide fish habitat and waterfowl food, and the plant has been used for river habitat restoration by the U.S. Army Corps of Engineers (Smart and others, 2005). Abundant growth of water stargrass in the Yakima River, however, can provide habitat for introduced fish species such as largemouth bass that can prey on small salmonid fishes.

Water stargrass typically grows in shallow water up to $1 \mathrm{~m}$ deep (Hamel and others, 2001), although it tolerates decreased water transparency (Davis and Brinson, 1980) and has been observed at depths of more than $4 \mathrm{~m}$ in lakes (Davis and Brinson, 1980). The roots are fibrous and grow from rhizomes in and on the riverbed (Hamel and others, 2001). The root systems of water stargrass beds in the Yakima River extended well into the river bed. Water stargrass may overwinter as a dormant root crown (Smart and others, 2005) or, if conditions permit, as entire plants (Horn, 1983). Growth begins in spring when water temperatures exceed $8^{\circ} \mathrm{C}$ and ends when water temperatures fall below $10^{\circ} \mathrm{C}$ (Horn, 1983).

Differences in substrate stability may account for the substantial differences in macrophyte biomass between the Zillah, Mabton, and Kiona reaches in 2005. In the Zillah reach, the river flows on alluvial and glacial deposits, allowing the river channel and its cobble substrate to move more readily than in the Kiona reach, where much of the river is constrained by bedrock. In the Mabton reach, the soft unconsolidated mud substrate moves even more readily during high water events than the cobble substrate in the Zillah reach (Jim O'Connor, U.S. Geological Survey, oral commun., 2007). As a result, macrophytes in the Zillah and Mabton reaches may not have a stable base on which to establish and expand year after year.

The large differences in macrophyte biomass between the Zillah, Mabton, and Kiona reaches in 2005 could not be explained by reach-scale differences in light availability, velocity, or water temperature. Although light was insufficient for macrophyte colonization more often and in more locations in the Mabton reach compared to the other two reaches, light penetration generally was adequate for plant colonization in all three reaches of the river. Velocities were similar in the Zillah and Kiona reaches but macrophyte biomass was much higher in the Kiona reach, and the water temperature in all three reaches was warm enough throughout the growing season to support macrophyte growth.

The large differences in macrophyte biomass between reaches in 2005 also did not correspond to reach-scale differences in water-column or bed-sediment nutrient concentrations. Although the median macrophyte biomass 
in the Zillah and Mabton reaches were equal to $0 \mathrm{~g} / \mathrm{m}^{2}$, the concentrations of bioavailable nutrients in the Mabton reach were 4 times greater than the concentrations in the Zillah reach, and although the concentrations of bioavailable nutrients in the Kiona reach were comparable to the concentrations in the Mabton reach, the macrophyte biomass in the Kiona reach was much higher. A previous study determined that the median concentration of total phosphorus in the Quaternary deposits underlying the Zillah reach was similar to the median concentration in the Columbia River Basalt group rocks underlying the Kiona reach $(0.10$ and 0.09 percent, respectively) (Fuhrer and others, 1994); another study determined that the mean concentration of total phosphorus in the sediments of the Yakima River was 0.096 percent (Carlile and McNeal, 1974). The latter study, however, did not compare the longitudinal differences of biologically available forms of phosphorus in Yakima River sediments.

The gradual increase in macrophyte biomass in the Kiona reach between 2001 and 2005, followed by an abrupt decrease in 2006 and 2007, was best explained by changes in turbidity and streamflow (both of which influenced light availability) during that period. The number of days with above-average spring streamflow in the Yakima River declined from 1997 through 2005 including droughts in 2001 and 2005. Spring streamflow in the lower Yakima River is dominated by snowmelt from the Cascades, and below-average snowpack was measured during 4 of the 6 years between 2000 and 2005 . Modest or low spring runoff would have decreased turbidity, depth, and velocity and led to improved growing conditions for macrophytes in the spring.

Implementation of improved irrigation practices by growers in the lower Yakima Valley during the 1990s decreased erosion and reduced the amount of sediment entering the Yakima River, causing a reduction in the loads and concentrations of suspended sediment during the irrigation season at Kiona between 1995 and 2003 (Coffin and others, 2006). The median turbidity at Kiona during the irrigation season decreased between 1995 and 2005 (Washington Department of Ecology, 2008). The decrease allowed sunlight to penetrate deeper through the water and create conditions more favorable for macrophyte growth throughout the irrigation season.

Increased spring runoff in 2006 and 2007 due to higher snowpack in the Cascades led to conditions that were not as favorable for macrophyte growth. The river generally was more turbid, deeper, and faster from March through June during 2006 and 2007 compared to 2005. Between March 1 and June 30 in 2005, 2006, and 2007 the median turbidity at Kiona was 4.6 FNU, 18 FNU, and 15 FNU, respectively. The median turbidity exceeded $10 \mathrm{FNU}$ on $7.3,66$, and 54 percent of the days between March 1 and June 30 in 2005, 2006, and 2007, respectively. The mean gage height at Kiona during the same period was $3.8 \mathrm{ft}$ in 2005, whereas it was $6.3 \mathrm{ft}$ in 2006 and $6.6 \mathrm{ft}$ in 2007. During routine streamflow measurements at Kiona the velocity in the river was lower during spring 2005 than in 2006 and 2007 (Gregory Ruppert, U.S. Geological Survey, written commun., 2008), which may have allowed plants to grow in more locations across the cross section in 2005.

\section{Physical Factors Related to Dissolved Oxygen and $\mathrm{pH}$ Conditions}

Any complex dissolved oxygen model developed for the lower Yakima River would need to include the parameterization of the relation between dissolved oxygen concentrations and the respiration associated with autotrophic and heterotrophic metabolism. Because the parameterization of this relation might be difficult, understanding the relation between daily minimum dissolved oxygen concentration and a parameter that is relatively easy to predict and might be related to respiration, such as water temperature (Hill and others, 2000), could be useful.

The daily minimum dissolved oxygen concentrations and water temperatures at Kiona, Mabton, and Zillah occurred in the early morning. This pattern was opposite of the expected pattern from temperature-controlled equilibrium (higher dissolved oxygen solubility with lower water temperature), and was due to respiration by aquatic plants and animals. The daily minimum dissolved oxygen concentration at Kiona, Mabton, and Zillah also was strongly and negatively related to the maximum water temperature on the preceding day (table 13). The explanatory power of this linear relation did not increase when other factors such as streamflow and turbidity were included. A weak linear relation $\left(r^{2} \leq 0.23\right)$ also was noted between daily maximum $\mathrm{pH}$ at Kiona and maximum water temperature.

Although the dissolved oxygen - temperature model was able to reproduce the general patterns in daily minimum dissolved oxygen levels, it tended to have a positive bias in the year with the greatest macrophyte growth (2005) and a negative bias in the years with relatively low macrophyte growth (2006 and 2007) (fig. 27). For some periods in each

Table 13. Linear relations between daily minimum dissolved oxygen concentration and maximum water temperature on the previous day, Yakima River at Kiona (RM 30), Mabton (RM 55), and Zillah (RM 87), Washington, March 1-September 30, 2004-07.

[All relations were significant $(p \leq 0.001)$. Abbreviations: $r^{2}$, coefficient of determination for linear relation]

\begin{tabular}{lc}
\hline Location and year & $\boldsymbol{r}^{2}$ value \\
\hline Kiona, 2004-07 & 0.85 \\
Kiona, 2004 & 0.88 \\
Kiona, 2005 & 0.94 \\
Kiona, 2006 & 0.89 \\
Kiona, 2007 & 0.95 \\
Mabton, 2005 & 0.78 \\
Zillah, 2005 & 0.83 \\
Zillah, 2006 & 0.93 \\
\hline
\end{tabular}



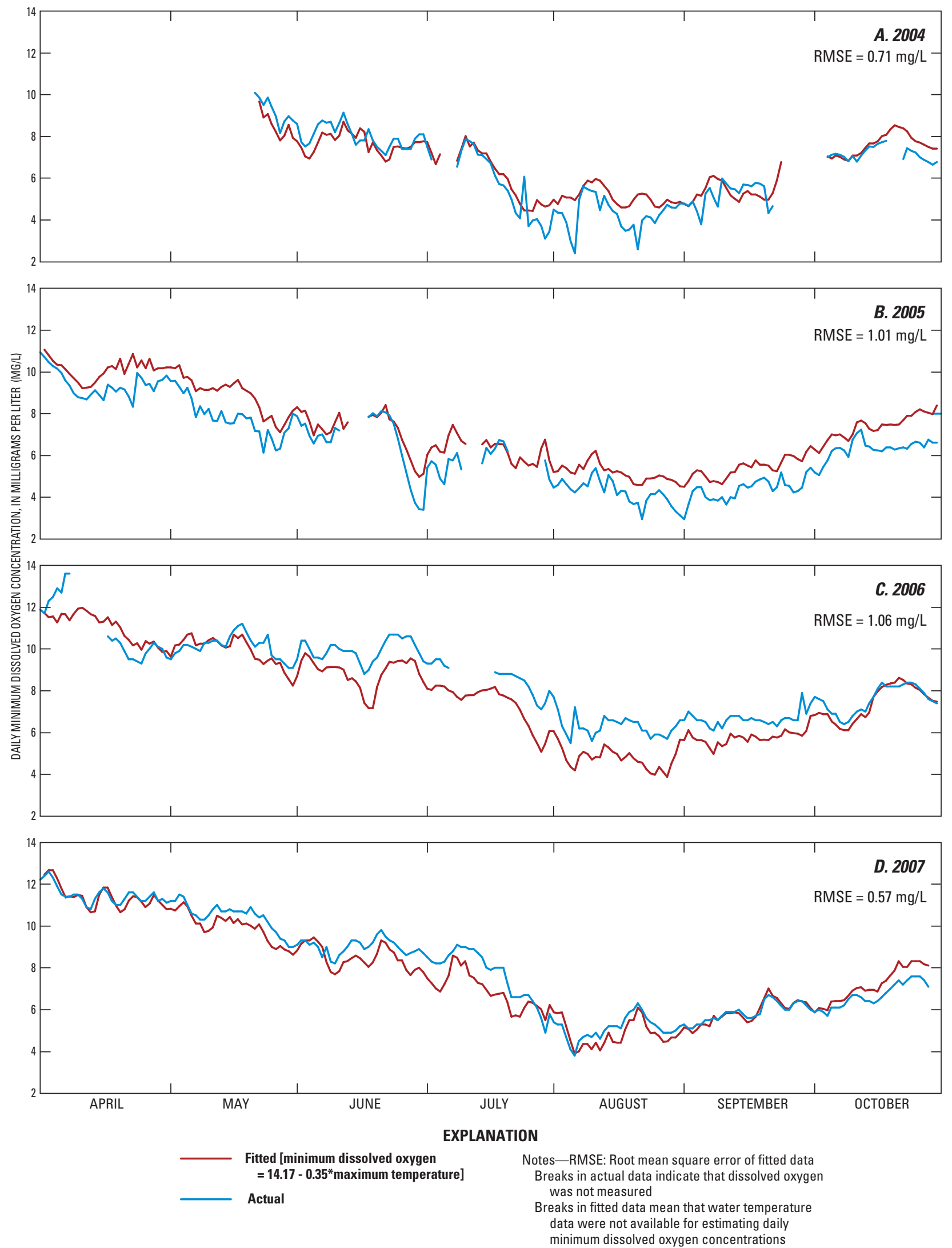

Figure 27. Comparison between fitted and actual daily minimum dissolved oxygen concentrations for the Yakima River at Kiona (RM 30), Washington, March 1-September 30, 2004-07. 
year, however, the fitted values were within the allowable error for dissolved oxygen readings $(0.30 \mathrm{mg} / \mathrm{L})$. The

RMSE value in figure 27 represents the mean distance of the measured data from the fitted line (expressed in milligrams per liter) and evaluates how well the model fit the measured data for each year. On the basis of RMSE values the model was most accurate in 2007 and least accurate in 2005. The strong relation between the daily minimum dissolved oxygen concentration and water temperature could prove useful if a dissolved oxygen predictive model is developed for the lower Yakima River, and it also could be used as a simple standalone model for assessing water-quality conditions.

The summer monitor deployments in the Zillah reach in 2006 and 2007 with the highest water temperatures tended to have a higher percentage of time when the concentrations of dissolved oxygen were below the Washington State standard, whereas the opposite was true for the monitor deployments with the lowest water temperatures. These results were consistent with the strong relation between water temperature and minimum dissolved oxygen concentrations during the seasonal monitor deployments at Kiona, Mabton, and Zillah. There appeared to be no relation, however, between water temperature and $\mathrm{pH}$ during the 2006 and 2007 monitor deployments in the Zillah reach or the Naches River.

\section{Factors Related to Spring Gross Primary Productivity at Kiona}

The relations between the spring GPP at Kiona and five environmental factors were reviewed to determine the relative importance of each factor: (1) the daily mean streamflow at Kiona, (2) the daily median turbidity measured at Kiona, (3) the photoperiod (time between sunrise and sunset), (4) the daily mean photosynthetically active radiation (PAR) measured at a nearby meteorological station (Prosser, WA) (Washington State University, 2007), and (5) the daily maximum water temperature measured at Kiona.

The strongest factor affecting spring GPP was daily mean streamflow, which was negatively related to GPP (fig. 28): greater values for GPP related significantly to lower values for daily mean streamflow. Figure 28 shows how the GPP value was more responsive to small increases in streamflow during periods of lower streamflow than during periods of higher streamflow. An increase from 500 to $1,500 \mathrm{ft}^{3} / \mathrm{s}$ in the daily mean streamflow corresponded to a decrease of $6.64 \mathrm{~g} / \mathrm{m}^{2} / \mathrm{d}$ in GPP, whereas an increase from 4,000 to $5,000 \mathrm{ft}^{3} / \mathrm{s}$ in the daily mean streamflow corresponded to a decrease of only $1.64 \mathrm{~g} / \mathrm{m}^{2} / \mathrm{d}$ in GPP.

Although high streamflows can suppress aquatic plant growth by disrupting the streambed in which macrophytes are rooted and on which periphyton grow, no known beddisturbing events occurred in the Kiona reach during this
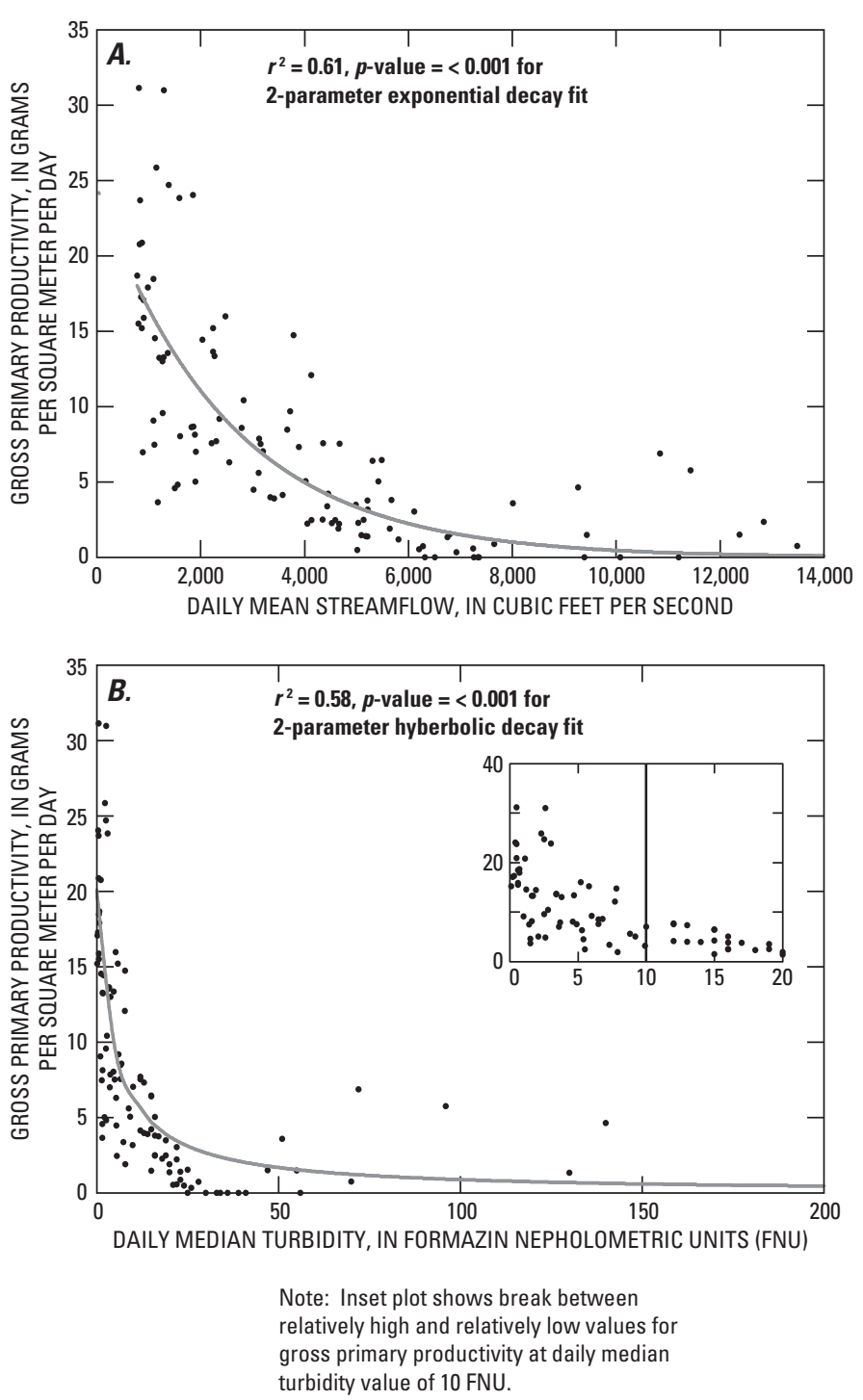

Figure 28. Relation between gross primary productivity and $(A)$ daily mean streamflow and $(B)$ daily median turbidity for the Yakima River at Kiona (RM 30), Washington, March 1-June 30, 2005-07.

study. Therefore, the decrease in spring GPP that corresponded to high streamflow likely was due to the increased turbidity and water depth (and thus a decrease in light availability) associated with the high streamflow. The effect of water depth on GPP could not be determined because it was not independent from the GPP calculation, but the effect of turbidity on GPP could be, given that GPP was related negatively to the daily median turbidity (fig. 28). The mean GPP when the turbidity was below $10 \mathrm{FNU}$ was $12.95 \mathrm{~g} / \mathrm{m}^{2} / \mathrm{d}$ and was significantly greater than the mean value of $3.11 \mathrm{~g} / \mathrm{m}^{2} / \mathrm{d}$ when the turbidity was above $10 \mathrm{FNU}$. 
Spring GPP was related positively (but weakly) to the photoperiod and the daily maximum water temperature, but during periods of low streamflow (and greater light availability) GPP also was related to daily mean PAR (table 14). All these variables are expected to influence plant growth in the Yakima River, but none can be considered in isolation because of the interdependence between them.

\section{Evaluation of the Gross Primary Productivity Method}

The results from this study showed that spring GPP estimates for the Kiona reach were consistent with the maximum macrophyte biomass for a growing season and provided information on the important factors affecting macrophyte growth during this critical period in the life cycle of the plants. In contrast, the summer GPP estimates for the Kiona reach were not consistent with the maximum macrophyte biomass for a growing season.

Other researchers have obtained GPP estimates that did not appear to correspond to the level of macrophyte biomass. Thyssen (1982) speculated that increased metabolic activity from benthic algae was the reason that he determined no significant effect on photosynthesis and respiration in a stream when macrophytes were removed. Kaenal and others (2000) determined that macrophytes and their associated epiphytes contributed to stream metabolism in nutrient-rich, unshaded streams, that stream metabolism may not be dominated by macrophytes even when macrophyte biomass is high, and that GPP recovered quickly after macrophyte removal probably because of the growth of benthic algae where plants previously had grown.

Although this study did not attempt to determine the relative contribution of different plant types (periphyton, epiphyton, and macrophytes) to the total plant productivity, the results strongly indicated that aquatic plants other than macrophytes were responsible for much of the productivity occurring in the Kiona reach during summer. Abundant epiphytic algal growth commonly was observed on the macrophytes in the Kiona reach, filamentous green algae was observed growing in open spaces between plant beds, and the mean rate of periphytic algal accrual measured in the reach during one periphytometer experiment in 2007 was greater than most of the mean accrual rates measured in the Zillah reach in 2006 and 2007 when periphyton was at nuisance levels in some areas.

The GPP methodology is not appropriate when large oxygen loss from the water occurs in the form of bubbles (Britton and Greeson, 1989), when oxygen transfer to the
Table 14. Linear relations between gross primary productivity and environmental factors in the Yakima River at Kiona (RM 30), Washington, March 1-June 30, 2005-07.

$\left[r^{2}\right.$ values are shown only for significant relations $(p \leq 0.05)$. Abbreviations: $r^{2}$, coefficient of determination; $\leq$, less than or equal to; - , not significant]

\begin{tabular}{lcc}
\hline Environmental factor & $\begin{array}{c}\boldsymbol{r}^{2} \text { value, } \\
\text { all data }\end{array}$ & $\begin{array}{c}\boldsymbol{r}^{2} \text { value, data } \\
\text { corresponding to first } \\
\text { quartile of streamflow }\end{array}$ \\
\hline $\begin{array}{c}\text { Photoperiod } \\
\text { Daily mean pho- } \\
\text { tosynthetically } \\
\text { active radiation }\end{array}$ & 0.12 & 0.66 \\
$\begin{array}{l}\text { Daily maximum water } \\
\text { temperature }\end{array}$ & 0.43 & 0.64 \\
\hline
\end{tabular}

atmosphere occurs through emergent plants, or if heterotrophic respiration is a large part of the community respiration (Bales and Nardi, 2007). During summer 2005 bubble formation in and around the densest macrophyte beds in the Kiona reach was common and macrophytes were emergent in large areas of the reach. These plants often had numerous heterotrophic organisms attached such as Simulid black fly larvae, Brachycentrus caddisflies, and other types of organisms. Although all these factors might have caused GPP to be underestimated during summer 2005, another indicator of primary productivity, the median daily range in $\mathrm{pH}$, strongly indicated that summer GPP in the Kiona reach was similar between 2005-07. The median daily range in $\mathrm{pH}$ between July 1 and September 30 was not significantly greater in 2005 compared to the median daily ranges in 2006 and 2007, even though there was substantially more macrophyte biomass in 2005.

A comparison of the one-station and two-station whole-stream productivity results showed that, although the one-station method is adequate in reaches with low levels of macrophyte growth, the two-station method might be necessary in reaches with abundant macrophyte growth to account for variations in reach conditions that cannot be represented by one water-quality station. The differences between the one-station and two-station estimates at Zillah during summer 2005 and at Kiona during summer 2007 were generally low ( $<11$ percent); however, all but one of the twostation estimates at Kiona during summer 2005 were greater than the one-station estimates, and the difference between the two estimates averaged 17 percent and was as high as 62 percent. 


\section{Comparison of Results to Historical Conditions}

\section{Aquatic Plants}

For many years, the concentrations of phosphorus and nitrogen measured in the lower Yakima River have been high enough to support abundant growth of phytoplankton, periphyton, and macrophytes (Rinella and others, 1992), but macrophyte growth was not widespread or problematic. In the late 1980 s, scattered patches of dense macrophytes were noted at one site downstream of Satus Creek near RM 70 (Rinella and others, 1992). A presence-absence survey at a limited number of locations: the Yakima River at Parker (RM 104), below Toppenish Creek near Satus (RM 80), and at Kiona, did not note any macrophytes (Cuffney and others, 1997). Other researchers, however, noted the presence of rooted aquatic plants within the lower Yakima River, especially in the vicinity of Horn Rapids Dam (RM 18) (Morace and others, 1999).

Since those studies were completed, light availability and streamflow conditions in the river have often been favorable for macrophyte growth. Macrophyte growth noticeably increased in the lower river beginning in 2001 (Richard Visser, Washington Department of Fish and Wildlife, written commun., 2002). USGS personnel noted the recent spread of "river grass" near the gaging station at Kiona in June 2001, after many years of decreasing turbidity and spring streamflow and after a spring that had the second lowest mean streamflow on record for that gaging station. USGS personnel noted that the "river grass" returned during each summer in 2002 and 2003.

USGS personnel also have observed nuisance levels of aquatic growth at Kiona in the more-distant past (fig. 29). Starting in 1933, the field notes for the gaging station showed a clear relationship between low streamflow in

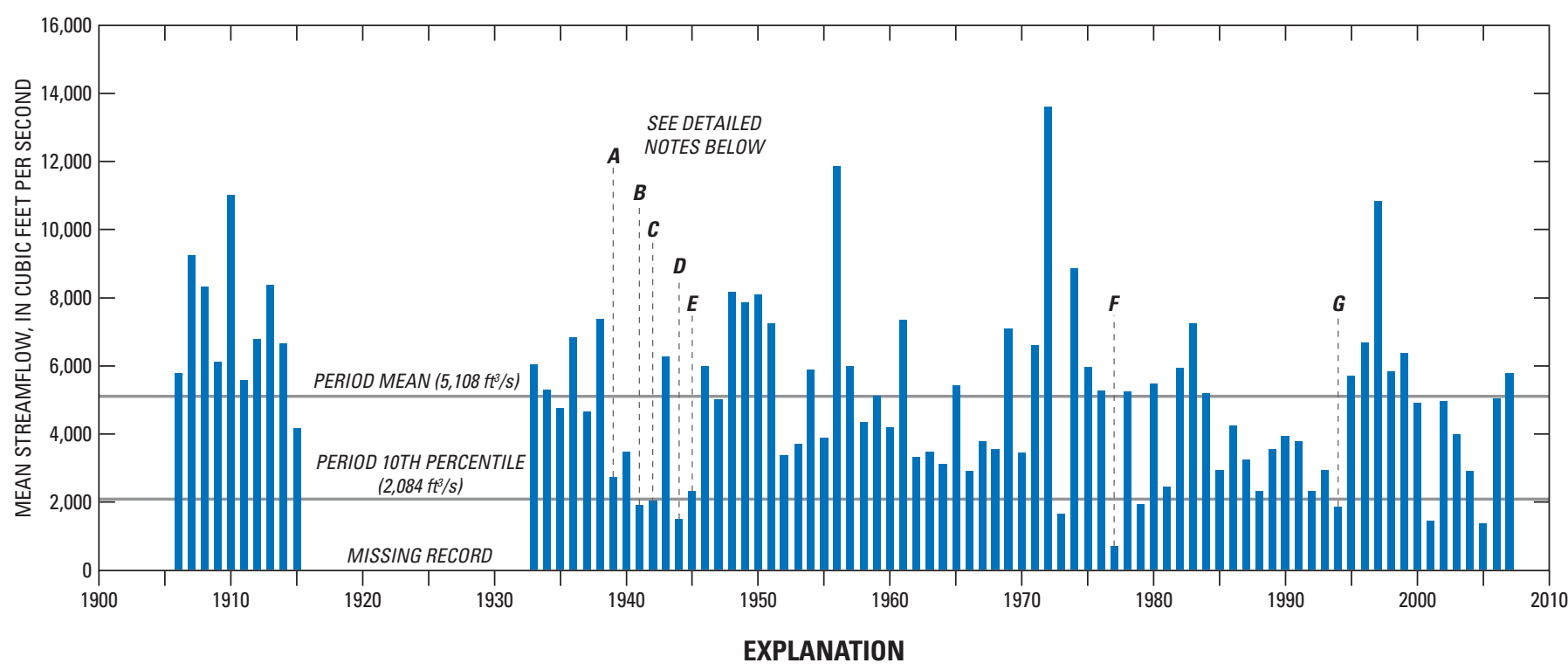

U.S. Geological Survey field technician notes for Yakima River at Kiona:

A. 1939: "At the time of this measurement (July 11th), there were quantities of aquatic growth running in the water, which necessitated cleaning the meter quite frequently."

B. 1941: "(The summertime measurements) show some effects of weed growth during June, July, and August. The hydrographers complain of the moss catching in the meter and thus interfering with making the measurement. This (aquatic growth) becomes entangled in the meter and in some places makes it impossible to even set the meter at the right depth. Measurement No. 241, made by Smith on September 15, plats +5.2 percent from this (February 3,1937 ) rating. The error (shift from winter rating) is caused largely by moss-effect."

C. 1942: "Measurement No. 257, made by Jenne on July 3, was weed affected and plats -4.8 percent from rating dated February 11,1935 . To check this measurement, Mr. Jenne made measurement No. 258 on July 8 , after cleaning the weeds out from under the cable. Throughout the summer the hydrographers complained about the moss in the stream bed which apparently affected the measurements.
D. 1944: "The stream bed at this station is thoroughly infested with river grass. This condition indicates an unstable control. Under certain conditions some of the control scoured and at other times silted up due to the weight of the weed growth on individual stones in the control and the breaking away of, or silting up of, the grass on the control."

E. 1945: "It is believed that these (summertime) measurements were affected by the heavy weed growth that infests the river bed at this station."

F. 1977: "(Measurement) Nos. $694-695$ indicated shifts of -0.10 and $-0.20 \mathrm{ft}$. These shifts were needed to correct for aquatic growth."

G. 1994: June through September-"Light aquatic growth on control (riffle at gage)."

Field notes provided by the Bureau of Reclamation.

Figure 29. Spring streamflow and U.S. Geological Survey field notes for the Yakima River at Kiona (RM 30), Washington, March 1-June 30, 1906-07. 
spring (March 1-June 30) and the mention of aquatic growth, including one reference to "river grass". In almost all years when field personnel noted aquatic growth in the river (1939, $1941,1942,1944,1945,1977$, and 1994), the mean spring streamflows were less than 10 percent of the mean spring streamflows for the station. Based on recent and historical observations at the Kiona gaging station, the macrophyte growth in the lower river appears to follow a pattern where plant growth increases during periods with low spring streamflow and decreases during periods of average or aboveaverage spring streamflows - a pattern that also was observed during this study.

\section{Nutrients, Suspended Sediment, and Turbidity}

The median concentrations of DIN and suspended sediment at Kiona were significantly less during 2001-03 than the median concentrations during 1975-2000 (fig. 30A, $\underline{\text { ) }}$, even though the mean streamflow was significantly less during 2001-03. In contrast, the median concentration of SRP at Kiona was significantly greater during 2001-03 than the median concentration during 1975-2000 (fig. 30B). These two periods were selected for comparison because the years 1975-2000 were before the recent period of below-average spring streamflows, whereas the years 2001-03 were during the recent period of below-average spring streamflows.

These results indicate that the DIN and suspended sediment loads in the river decreased between the two periods, because concentrations would have increased if there had been no change in load. The decreased DIN load could have been due to decreases in the load from agricultural return drains during the period - the mean irrigation-season nitrate loads from Sulphur Creek Wasteway and Granger Drain were 34 percent and 24 percent less, respectively, during the 2001-04 period compared to the 1997-2000 period (Zuroske, 2006). The decreased suspended sediment load likely was due to a combination of lower sediment loading to the river from agricultural return drains and an increase in sediment deposition in the Kiona reach due to the presence of macrophytes.
A Lagrangian synoptic survey of the Yakima River for nutrients and suspended sediment was conducted by the USGS between July 26 and 29, 1988 (Rinella and others, 1992) and sampled many of the same sites that were sampled during the 2004 survey. The pattern in the longitudinal nutrient and sediment loads was similar during both years-relatively high loads upstream of the Parker diversions, decreasing substantially after the diversions, increasing steadily until Prosser Dam, decreasing after the diversion for the Chandler Canal, and increasing after the return from Chandler Canal (fig. 31).

The median spring (March 1-June 30) turbidity at Kiona was significantly less during 2004-05 compared to 19782000, but significantly greater during 2006-07 compared to 1978-2000 (turbidity data was not available before 1978) (fig. 32). The median summer (July 1-August 31 ) turbidity at Kiona was significantly less during 2004-05 and 2006-07 compared to 1978-2000.

\section{Dissolved Oxygen and pH}

The results from 3 days of continuous monitoring by WA DOE in late July 2000 at Kiona (the only continuous monitoring data available for Kiona before the start of this study) showed a daily range in dissolved oxygen concentration of about $3.7 \mathrm{mg} / \mathrm{L}$ and a minimum daily dissolved oxygen concentration of $7.5 \mathrm{mg} / \mathrm{L}$. This was slightly below the Washington State standard of $8 \mathrm{mg} / \mathrm{L}$, but not nearly as low as the daily minimum dissolved oxygen concentrations measured during late July 2004 and 2005, when the concentrations were consistently below $6 \mathrm{mg} / \mathrm{L}$ and often below $4 \mathrm{mg} / \mathrm{L}$. The daily minimum dissolved oxygen concentrations in 2000 were similar to the daily minimum values measured during late July 2006, when macrophyte biomass levels were the lowest of any year during this study. The maximum daily $\mathrm{pH}$ level in late July 2000 (8.7 units) was greater than the Washington State standard of 8.5 units, similar to the maximum daily $\mathrm{pH}$ measured in late July 2004 and 2006, but less than the values measured in late July 2005 and 2007. 


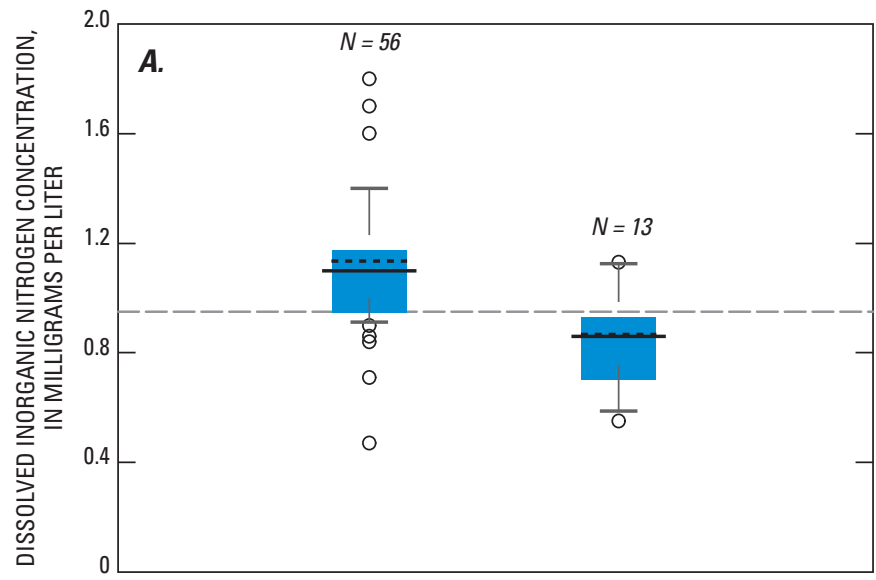

\section{EXPLANATION}

O Data value greater than the 90th percentile

90th percentile
75th percentile

Median

Mean

25th percentile

10th percentile

O Data value less than the 10th percentile

Concentrations measured in July 2004

$N=19 \quad$ Number of samples
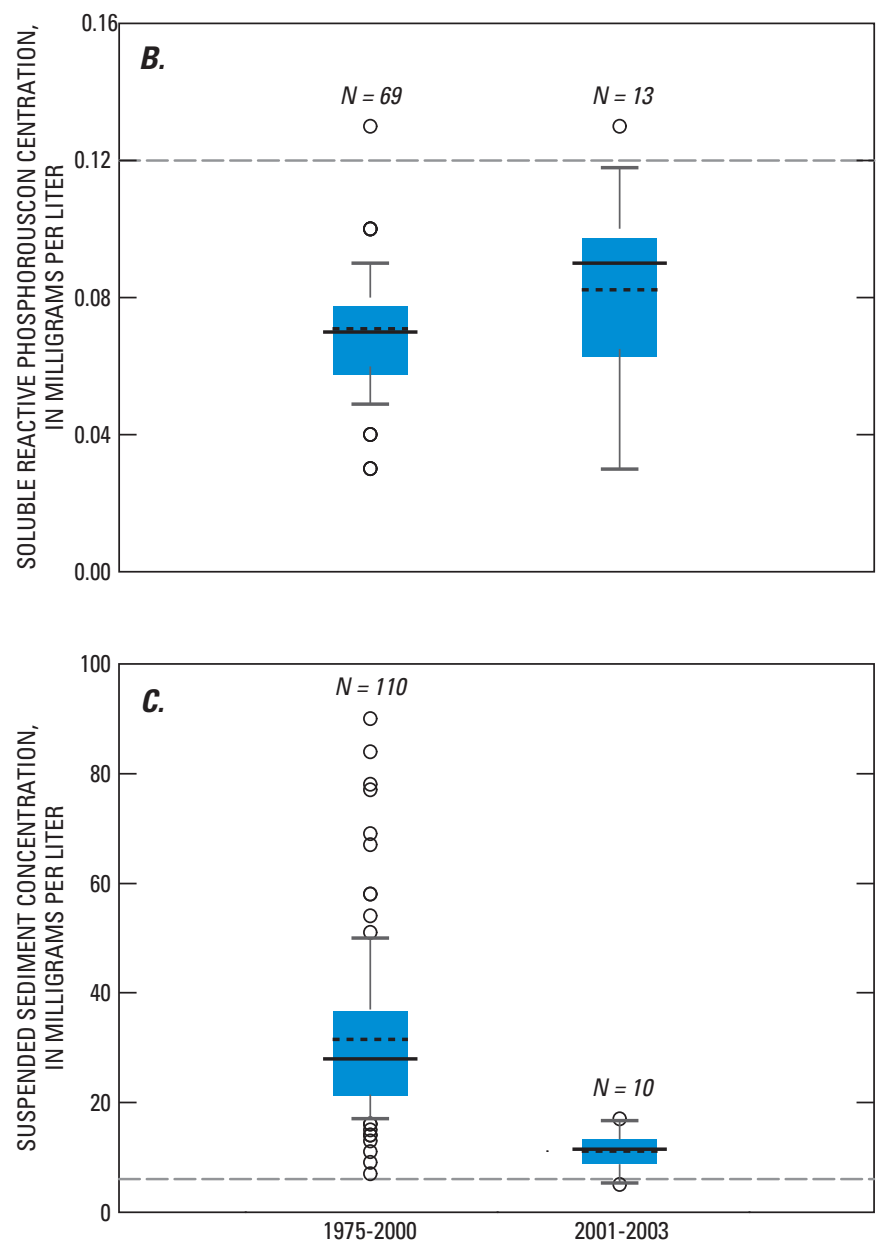

Figure 30. Concentrations of $(A)$ dissolved inorganic nitrogen, $(B)$ soluble reactive phosphorus, and $(C)$ suspended sediment measured at the Yakima River at Kiona (RM 30), Washington, July 1-September 30, 1975-2000 and 2001-03, and July 29, 2004. 

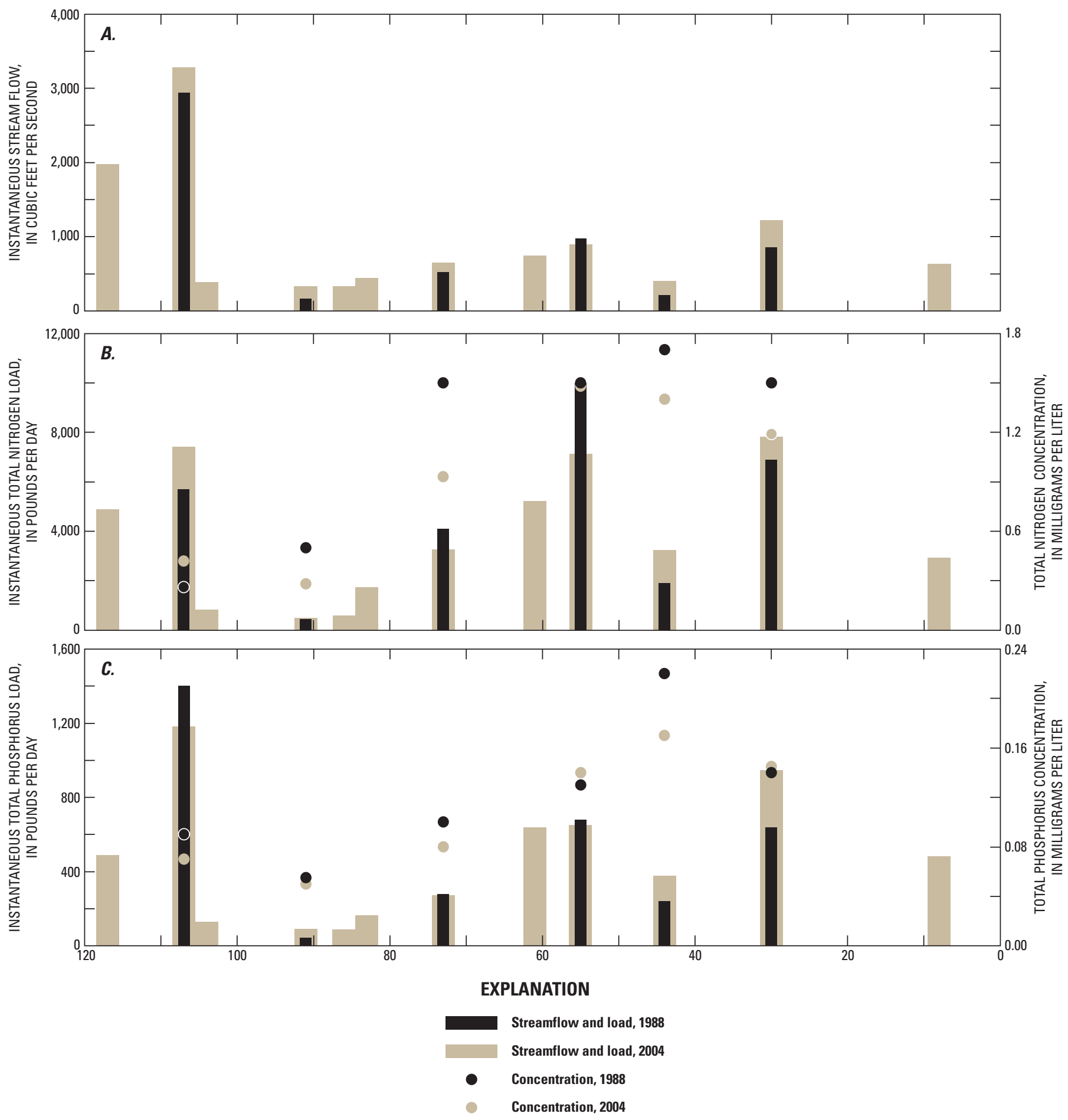

Figure 31. Instantaneous $(A)$ streamflows, $(B)$ total nitrogen loads and concentrations, and $(C)$ total phosphorus loads and concentrations in the Yakima River, Washington, July 26-29, 2004, and July 26-29, 1988. 

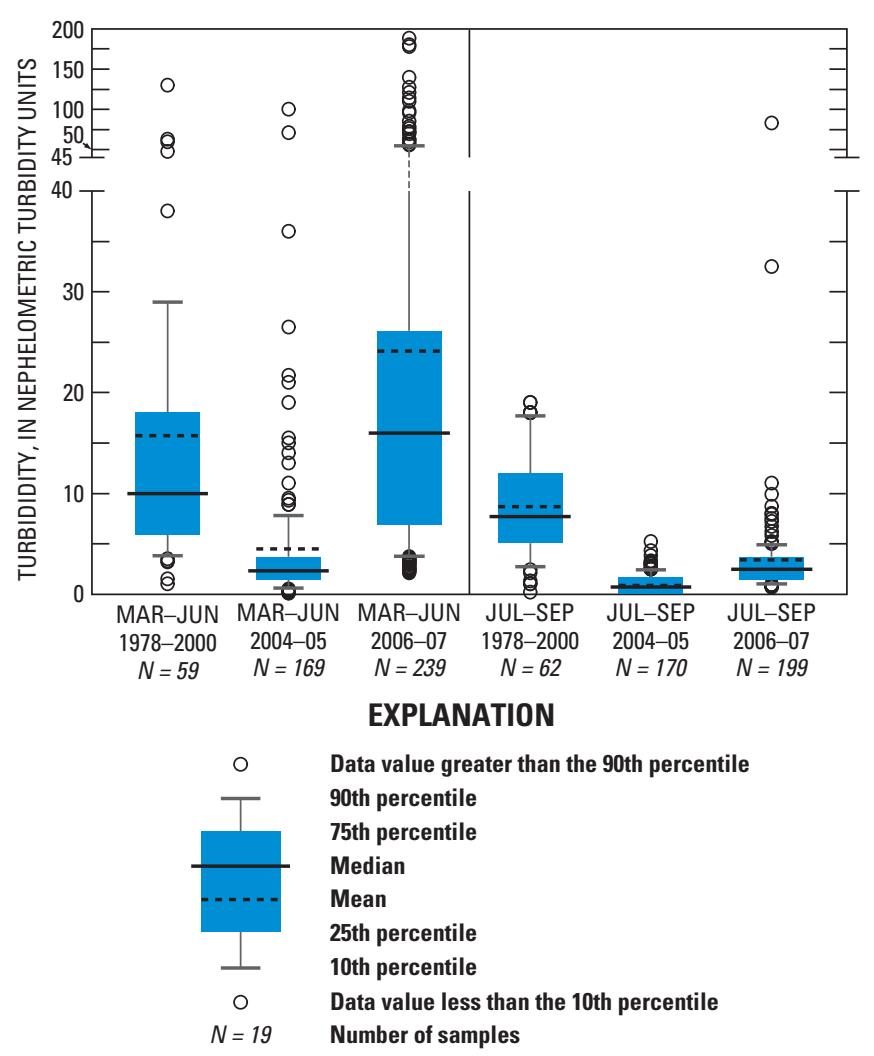

Note: 1978-2000 results are discrete depth- and widthintegrated samples collected by the U.S. Geological Survey and are in NTU (Nephelometric Turbidity Units). 2004-07 results are daily median values measured in FNU (Formazin Nephelometric Units).

Turbidity measured in FNU in the Yakima River between 2004 and 2007 was, on average, equal to 95 percent of the turbidity measured in NTU.

Figure 32. Summary of turbidity monitoring, Yakima River at Kiona (RM 30), Washington, 1978-2000 and 2004-07.

\section{Potential Management Strategies to Improve Conditions}

The complex relations between the growth of aquatic plants in the Yakima River and the key factors that control growth (such as nutrient concentrations, light availability, and the physical characteristics of the river) will need to be considered when a strategy is developed for improving waterquality conditions in the lower Yakima River. Streamflow modification and nutrient reductions are the two general approaches available to water-quality managers for reducing algal growth. In addition to these approaches, macrophyte growth can be reduced through direct management (for example, cutting and harvesting).

\section{Streamflow Modification}

For the same level of plant productivity, the dilution caused by an increase in streamflow entering the Zillah reach might result in higher dissolved oxygen concentrations and lower $\mathrm{pH}$ levels compared to the existing streamflow. An increase in streamflow in the Zillah reach, however, also might create additional surface area for algal growth, because of large deposits of cobble and other suitable habitats that are out of the water and not inundated with the current level of summer streamflow.

Although differences in light availability appeared to be the reason for the differences in macrophyte abundance between years in the Kiona reach, it would not be possible in a series of water-limited years for spring runoff to be great enough to create the prolonged turbid and deep conditions necessary to suppress macrophyte growth. The relatively stable substrate in much of the Kiona reach likely would not be disturbed under normal annual streamflow conditions in the lower Yakima River - no evidence was found that large areas of substrate were disturbed in the Kiona reach during this study even though the streamflow during some periods was $10,000-16,000 \mathrm{ft}^{3} / \mathrm{s}$.

\section{Nutrient Reductions}

The lowest nutrient concentrations of any of the three Yakima River reaches evaluated in this study were measured in the Zillah reach. The abundant algal growth and sparse macrophyte growth in the reach indicated that benthic algal metabolism was the primary reason for the exceedences of the water-quality standards for dissolved oxygen and $\mathrm{pH}$. Because of the relatively low nutrient concentrations in the Zillah reach and the indication of intermittent nutrient limitation at two locations, dissolved oxygen and $\mathrm{pH}$ conditions might improve from reductions in nutrient concentrations in the reach. This could be accomplished by either reducing the nutrients entering the reach or increasing the amount of lowernutrient concentration water entering the reach from upstream. Accurate predictions regarding the potential effectiveness of this approach requires information on the quantity and quality of ground water entering the river. The level of effort needed to reduce the amount of nutrients and algal growth in the river, however, will remain unknown until a better understanding of the relation between nutrient availability and primary productivity is developed.

Although the amount of nutrients in the Mabton reach could be reduced through nutrient reductions in the Zillah reach, the effect on aquatic plant growth and dissolved oxygen and $\mathrm{pH}$ conditions would be minimal unless nutrient loads from the agricultural return drains and other tributaries within the Mabton reach also were reduced. Even if this were to 
occur, the mean concentrations of dissolved nitrite plus nitrate and total phosphorus measured in the Mabton reach during this study would need to be reduced by 92 and 83 percent, respectively, to equal the suggested USEPA reference conditions for the Yakima basin.

Because almost all the nutrient load in the Kiona reach enters from the Mabton reach, substantial reductions in the Zillah and Mabton reaches will be necessary to reduce the loads of nutrients in the Kiona reach. Attempts to reduce nutrients in the river water might have no effect on plant abundance and the associated dissolved oxygen and $\mathrm{pH}$ problems, however, because heavily rooted aquatic plants such as water stargrass are able to obtain nutrients from either the water column or the bed sediment. The results from this study indicated that the macrophytes in the Kiona reach were not obtaining a measurable amount of their nutrients primarily from the river water, and the results from other studies have indicated that bed sediment usually provides a sufficient supply of nutrients for macrophyte growth.

\section{Direct Management of Macrophytes}

Direct management of the macrophytes (either through mechanical harvesting or some other type of control) might be the only feasible method for reducing macrophyte growth in the Kiona reach. Even a substantial reduction in macrophyte biomass, however, might not be sufficient to bring the Kiona reach into compliance with the water-quality standards for dissolved oxygen and $\mathrm{pH}$. There was a 97 percent reduction in macrophyte biomass between 2005 and 2006 in the Kiona reach, to a level that most fish habitat studies have determined to be optimal for streams, but exceedences of the Washington State water-quality standards for dissolved oxygen and $\mathrm{pH}$ still occurred. The role of benthic and epiphytic algae (growing along the river margins and on the plants) in this reach was not assessed, but could help explain the persistent water-quality problems.

\section{Potential For Future Studies}

The results from this study could be the foundation for further research into the relations between aquatic plant growth, nutrients, and dissolved oxygen and $\mathrm{pH}$ conditions in the lower Yakima River. In addition to the results from this study, three general areas of study might provide waterquality managers with enough understanding of the processes occurring in the river to improve dissolved oxygen and $\mathrm{pH}$ conditions.

\section{Water-Quality Models}

Models could be developed that can simulate the physical, chemical, and biological complexity of the lower Yakima River. Modeling may be able to estimate the effect of different streamflows on algal metabolism in the Zillah reach (for example, changes in habitat compared to dilution). Modeling also could examine the effect that reduced light availability from high streamflow or high turbidity would have on aquatic plant growth. Models developed to test hypotheses regarding the distribution and abundance of macrophytes throughout the lower river would benefit from an assessment of peak flows (timing and magnitude) and sediment flux to and through the river and the role of other factors (for example, light, biological complexities) on macrophyte growth.

The hydraulic model and water temperature model that were recently developed for the lower Yakima River (Hilldale and Mooney, 2007; Voss and others, 2008) could be used to estimate water temperature, depth, and velocity in the Zillah reach under different streamflow conditions and to relate those conditions to periphytic algal biomass.

Model predictions of dissolved oxygen in the lower Yakima River may be improved by adding the relation between dissolved oxygen and temperature data determined during this study to the water temperature model that was recently developed for the Yakima River between RM 129 and the Prosser Dam at RM 46 (Voss and others, 2008). This model could be extended from Prosser Dam to near the mouth of the river, which would allow for the prediction of daily minimum concentrations throughout the irrigation season in the Zillah, Mabton, and Kiona reaches.

\section{Continuous Water-Quality Monitoring}

The monitoring results from this study clearly showed the spatial (longitudinally through the lower river) and temporal (seasonally and yearly) variation in water-quality conditions and provided the data needed to estimate GPP. Continuous water-quality monitoring could provide the data necessary for further insight into the important factors controlling aquatic plant growth in the river and the effect of aquatic plant growth on dissolved oxygen and $\mathrm{pH}$ conditions. Data from the monitoring could help in model development and in assessing the effectiveness of future water-quality management actions.

\section{Isotope Studies}

An analysis of the isotopic composition of nitrate, organic matter, inorganic carbon, dissolved oxygen, and aquatic plants can provide fundamental information about the processes that 
influence the growth of algae and macrophytes in rivers. The results from this type of analysis might help determine the sources of nitrogen and carbon (such as wastewater treatment plants, fertilizer, manure, or atmospheric deposition) to the algae and macrophytes, how much of the productivity in the river is due to different forms of plant life (phytoplankton, attached algae, and macrophytes), and the relative importance of different stream organisms (plants, microbes, and insects) in respiration and oxygen depletion.

\section{Summary}

The results from this study showed that the concentrations of nutrients in the entire lower Yakima River were high enough at certain times and places to support the abundant growth of free-floating algae (phytoplankton), attached algae (periphyton), and vascular aquatic plants (macrophytes) and that the metabolism associated with this plant growth led to dissolved oxygen concentrations and $\mathrm{pH}$ levels that exceeded the Washington State water-quality standards. The abundance and distribution of these aquatic plants, however, varied greatly throughout the lower river and, in the case of macrophytes, between years because of substantial differences in spring streamflow.

\section{Aquatic Plant Conditions}

Aquatic plants in the lower Yakima River consisted of phytoplankton, periphytic algae, and several species of rooted macrophytes. Periphytic algae were especially abundant in the Zillah reach (RM 116-RM 72) and moderately abundant in the Kiona reach (downstream of RM 47). Periphytic algae were much less abundant in the Mabton reach (RM 72-RM 47) where, because of greater depths and longer residence times, conditions were more favorable for phytoplankton growth. The abundance of macrophytes was greatest in the Kiona reach (where water stargrass was the dominant species) compared to the other two reaches.

\section{Effect of Aquatic Plants on Dissolved Oxygen and pH Conditions}

Aquatic-plant assemblages and other organisms in the lower Yakima River had pronounced effects on the dissolved oxygen concentrations and $\mathrm{pH}$ levels. The effects of aquatic plant metabolism were observed during the growing season in all three reaches of the lower Yakima River, producing large daily swings in dissolved oxygen and $\mathrm{pH}$ during lowflow periods. The daily swings in dissolved oxygen and $\mathrm{pH}$ were not as extreme during the high-streamflow snowmelt periods in 2006 and 2007, however, because of the combined effects of dilution from higher streamflow and the decrease in available light for photosynthesis due to deep water and high turbidity.

The daily minimum dissolved oxygen concentrations were less than the Washington State standard of $8.0 \mathrm{mg} / \mathrm{L}$ during much of the irrigation season at Kiona (RM 30) during 2004-07, at Mabton (RM 55) and at Zillah (RM 87) during 2005, and at Zillah during 2006, but the period when the dissolved oxygen standard was exceeded at Kiona began earlier in 2004 and 2005 compared to 2006 and 2007 due to high spring streamflows in 2006 and 2007. The daily minimum dissolved oxygen concentrations at Kiona, Mabton, and Zillah were strongly related to maximum water temperature, and this relation could prove useful if a dissolved oxygen predictive model is developed for the lower Yakima River.

The daily maximum $\mathrm{pH}$ levels were greater than the Washington State standard of 8.5 at Kiona during almost all of the irrigation seasons in 2004 and 2005 and after the spring runoff periods in 2006 and 2007. Although the $\mathrm{pH}$ conditions at Mabton and Zillah were not as severe as those at Kiona, there were extended periods during the irrigation season when the $\mathrm{pH}$ standard was exceeded at both locations, especially at Zillah in 2005. The $\mathrm{pH}$ standard also was exceeded at Kiona during some periods between October and February during all years of the study.

\section{Nutrient Conditions}

The lowest nutrient concentrations generally were in the Zillah reach upstream of the major agricultural returns. Nutrient concentrations generally increased through the lower sections of the Zillah reach and the entire Mabton reach, which contained the major agricultural returns, and remained unchanged or decreased slightly in the Kiona reach. The nutrient concentrations in the Mabton and Kiona reaches during the irrigation seasons in 2004-07 almost always were greater than the reference conditions suggested by the U.S. Environmental Protection Agency to protect water bodies from the negative effects of nutrient enrichment. In contrast to the Kiona and Mabton reaches, the nutrient concentrations measured in the Zillah reach during the 2004-07 irrigation seasons often were less than the suggested USEPA reference conditions. The largest contributors of nutrient load to the Zillah reach were sources that enter upstream of the study area. About equal amounts of the nutrient load in the Mabton reach came from upstream of the reach and from nutrient-rich agricultural return drains and other tributaries, and almost all the nutrient load in the Kiona reach came from upstream of that reach. 


\section{Factors Related to Periphyton Biomass}

In addition to adequate dissolved nutrient concentrations in the Zillah reach, favorable habitat conditions help explain the abundant periphytic algae in this reach during summer. Light limitation and poor substrate conditions might explain the relatively low abundance of periphytic algae that was observed in the Mabton reach. The clear water and abundant macrophyte growth in the Kiona reach provided favorable conditions for epiphytic algal growth during summer.

Results from this study indicated that the longitudinal decrease in nutrient concentrations measured in the Zillah reach in summer was due to uptake by the abundant periphyton in the reach. Algal growth at some locations in the Zillah reach also might have been limited by the supply of nitrogen during summer. The lack of a positive relation between surface-water nutrient concentrations and algal biomass in the Zillah reach could mean that nutrients were being removed from the water by algae, that some combination of physical factors and (or) grazing by invertebrates were controlling algal growth, or that ground water was providing supplemental nutrients to the algae

\section{Factors Related to Macrophyte Biomass}

Differences in light availability appeared to be the reason for the substantially greater macrophyte biomass measured in the Kiona reach in 2005 compared to 2006 and 2007-higher turbidity and deeper water between March and June during 2006 and 2007 led to conditions that were not as favorable for macrophyte growth. These results were supported by the strong negative relation between high turbidity and low spring gross primary productivity (an estimate of the rate of plant growth) in the Kiona reach. Differences in substrate stability, rather than reach-scale differences in nutrient availability, light availability, velocity, or water temperature, may explain the substantially greater macrophyte biomass measured in the Kiona reach in 2005 compared to the Zillah and Mabton reaches. The substrate in the Kiona reach is more stable than the substrate in the Zillah and Mabton reaches, providing conditions that are more favorable to macrophyte growth.

Macrophyte growth in 2005 was not limited by either nitrogen or phosphorus in any of the three reaches. The results from this study indicated that the macrophytes in the Kiona reach were obtaining sufficient nutrients from the sediment in the river bed, which was consistent with the results from other studies that showed that macrophytes with extensive root systems (for example, water stargrass) are able to meet their nutrient needs completely from the bed sediment.

\section{Conclusion}

This study evaluated the key factors that controlled aquatic plant growth in the lower Yakima River and the effect that the plant growth had on dissolved oxygen and $\mathrm{pH}$ conditions. These complex relations, however, will need further investigation to develop a strategy for improving water-quality conditions in the lower Yakima River.

\section{Acknowledgments}

We thank the following people for assistance with this study: Ryan Anderson and Jenifer Parsons (WA DOE), Chauncey Anderson, Gerard Bales, Timothy Counihan, Gregory Fuhrer, Mark Madsen, Marc Munn, Mark Nardi, Jim O'Connor, Joe Rinella, and Ian Waite (U.S. Geological Survey), Stuart McKenzie (U.S. Geological Survey, ret.), and the attendees of the annual technical advisory group meetings (representing the Bureau of Reclamation, City of Yakima, National Marine Fisheries Service, North Yakima Conservation District, Roza Irrigation District, Roza-Sunnyside Board of Joint Control, Sunnyside Valley Irrigation District, U.S. Environmental Protection Agency, Washington State Department of Ecology, Washington State Department of Fish and Wildlife, Washington State University, Yakama Nation, Yakima Basin Joint Board, Yakima Basin Water Resources Agency, and Yakima County) for providing valuable feedback regarding the interpretation of the data and the design of the study; Michele Adams, Andy Arnsberg, Amy Brooks, Mary Janet, Matt Johnston, Dennis Lynch, Greg Olsen, Greg Ruppert, Ken Skach, Jay Spillum, Richard Wagner, Mark Weitz, and Roy Wellman (U.S. Geological Survey), Chris Coffin (WA DOE), Kenton Rod and Pat Vichit (Benton Conservation District), Pat Monk, James Thomas (Yakama Nation), Brian Neet, and Ann Stoller for help in the field and (or) managing the water-quality data; Quentin Krueter (Bureau of Reclamation) for providing discharge data for Bureau of Reclamation gages and compiling the historical records for the Kiona gaging station; the Yakama Nation, the operators of municipal wastewater treatment plants (the cities of Granger, Mabton, Prosser, Yakima, and Zillah), and private landowners (especially Jim Keene) for providing access to sampling and monitoring locations; the Bureau of Reclamation Pacific Northwest Laboratory in Boise, Idaho, for providing in-kind laboratory analysis; and the Washington Department of Ecology for providing funding for the project. 


\section{References Cited}

American Public Health Association, 1989, Standard methods for the examination of water and wastewater (17th ed.): Washington, D.C., American Public Health Association, $1136 \mathrm{p}$.

Anderson, Jeff, and Huggins, D.G., 2003, Production calculator, version 1.5, operations manual: Lawrence, Kan., Central Plains Center for Bioassessment, 23 p.

Bales, J.D., and Nardi, M.R., 2007, Automated routines for calculating whole-stream metabolism-Theoretical background and user's guide: U.S. Geological Survey Techniques and Methods 4-C2, 33 p.

Barko, J.W., Adams, M.S., and Clesceri, N.L., 1986, Environmental factors and their consideration in the management of submersed aquatic vegetation-A review: Journal of Aquatic Plant Management, v. 24, p. 1-10.

Barko, J.W., Gunnison, D., and Carpenter, S., 1991, Sediment interactions with submersed macrophyte growth and community dynamics: Aquatic Botany, v. 41, p. 41-65.

Biggs, B.F., and Close, M.E., 1989, Periphyton biomass dynamics in gravel bed rivers - The relative effects of flows and nutrients: Freshwater Biology, v. 22, p. 209-231.

Biggs, B.F., 1996, Patterns in periphyton of streams, in Stevenson, R.J., and Bothwell, M.L., eds., Algal ecologyFreshwater benthic ecosystems: London, Academic Press, p. 31-56.

Bott, T.L., 2006, Primary productivity and community respiration, Chapter 28 in Hauer, F.R., and Lamberti, G.A., eds., Methods in stream ecology ( $2^{\text {nd }}$ ed.): London, Academic Press, 877 p.

Bowden, W.B., Glime, J.M., and Riis, T., 2006, Macrophytes and bryophytes, Chapter 18 in Hauer, F.R., and Lamberti, G.A, eds., Methods in stream ecology ( $2^{\text {nd }}$ ed.): London, Academic Press, 877 p.

British Columbia Ministry of Environment, 2001, Water quality criteria for nutrients and algae: Environmental Protection Division, Ministry of Environment, accessed July 25, 2008, at http://www.env.gov.bc.ca/wat/wq/ BCguidelines/nutrients/nutrients.html
Britton, L.J., and Greeson, P.E., eds., 1989, Methods for collection and analysis of aquatic biological and microbiological samples: U.S. Geological Survey Techniques of Water-Resources Investigations, book 5, chap. A4, accessed July 25, 2008, at http://pubs.usgs.gov/ twri/twri5a $4 / \mathrm{html} / \mathrm{pdf} . \mathrm{html}$

Bureau of Reclamation, 2006, Bureau of Reclamation Hydromet System: Bureau of Reclamation, accessed February 20, 2008, at http://www.usbr.gov/pn/hydromet/ yakima/.

Carignan, R., 1982, An empirical model to estimate the relative importance of roots in phosphorus uptake by aquatic macrophytes: Canadian Journal of Fisheries and Aquatic Sciences, v. 39, p. 243-247.

Carlile, B.L., McNeal, B.L., Kittrick, J.A., Johnson, L.C., and Cheng, H.H., 1974, Characterization of suspended sediments in water from selected watersheds as related to control processes, nutrient contents, and lake eutrophication: Springfield, Virg., National Technical Information Service, PB233-167.

Carrol, Joseph, and Joy, Joseph, 2002, USBR Columbia River pump exchange project-Potential water-quality impacts on the lower Yakima River: Washington State Department of Ecology, publication no. 01-03-000, 123 p.

Carter, V.B., and Rybicki, N.B., 1990, Light attenuation and submersed macrophytes distribution in the tidal Potomac River and estuary: Estuaries, v. 13, no. 4, p. 441-452.

Chambers, P.A., and Prepas, E.E., 1989, Roots versus shoots in nutrient uptake by aquatic macrophytes in flowing waters: Canadian Journal of Fisheries and Aquatic Sciences, v. 46 , p. $435-439$.

Coffin, Christopher, Plotnikoff, Robert, and Anderson, Ryan, 2006, Lower Yakima River suspended sediment total maximum daily load-Effectiveness monitoring report: Washington State Department of Ecology, publication no. 06-03-014, $57 \mathrm{p}$.

Cuffney, T.F., Meador, M.R., Porter, S.D., and Gurtz, M.E., 1997, Distribution of fish, benthic invertebrate, and algal communities in relation to physical and chemical conditions, Yakima River Basin, Washington, 1990: U.S. Geological Survey Water-Resources Investigations Report 96-4280, 94 p.

Cushing, C.E., 1967, Periphyton productivity and radionuclide accumulation in the Columbia River, Washington, U.S.A.: Hydrobiologia, v. 29, nos. 1 and 2, p. 125-139. 
Davis, G.J., and Brinson, M.M., 1980, Responses of submersed vascular plant communities to environmental change: U.S. Fish and Wildlife Service, 70 p.

Dibble, Eric, Kafcas, Ernie, Maceina, Michael, and Mudrak, Vincent, 2005, Fish and wildlife habitat and invasive aquatic weed BMPs, in Petty, D.G., ed., Aquatic plant management-Best management practices in support of fish and wildlife habitat: Marietta, GA, Aquatic Ecosystems Restoration Foundation, 84 p.

Dodds, W.K., Jones, J.R., and Welch, E.B., 1998, Suggested classification for stream trophic state-Distributions of temperate stream types by chlorophyll, total $\mathrm{N}$ and P: Water Resources, v. 32, p.1544-1462.

Dodds, W.K., Smith, V.H., and Zander, B., 1997, Developing nutrient targets to control benthic chlorophyll levels in streams - A case study of the Clark Fork River: Water Resources, v. 31, p. 1738-1750.

Ebbert, J.C., Embrey, S.S., and Kelley, J.A., 2003, Concentrations and loads of suspended sediment and nutrients in surface waters of the Yakima River Basin, Washington, 1999-2000 - With an analysis of trends in concentrations: U.S. Geological Survey Water-Resources Investigations Report 03-4026, $100 \mathrm{p}$.

Fernandez-Alaez, Margaritz, Fernandez-Alaez, Camino, and Becares, Eloy, 1999, Nutrient content in macrophytes in Spanish shallow lakes: Hydrobiologia, v. 408/409, p. $317-$ 326.

Flipo, Nicoloa, Rabouille, Christophe, Poulin, Michel, Even, Stephanie, Tusseau-Vuillemin, Marie-Helene, and Lalande, Marie, 2007, Primary production in headwater streams of the Seine basin-The Grand Morin river case study: Science of the Total Environment, v. 375, p. 98-109.

Fuhrer, G.J., McKenzie, S.W., Rinella, J.F., Sanzolone, R.F., and Skach, K.A., 1994, Surface-water-quality assessment of the Yakima River basin in Washington-Analysis of major and minor elements in fine-grained streambed sediment, 1987: U.S. Geological Survey Open-File Report 93-30, $119 \mathrm{p}$.

Fuhrer, G.J., Morace, J.L., Johnson, H.M., Rinella, J.F., Ebbert, J.C., Embrey, S.S., Waite, I.R., Carpenter, K.D., Wise, D.R., and Hughes, C.A., 2004, Water quality in the Yakima Basin, Washington, 1999-2000: U.S. Geological Survey Circular 1237, 34 p.

Grimm, N.B., and Fisher, S.G., 1986, Nitrogen limitation in a Sonoran Desert stream: Journal of the North American Benthological Society, v. 5, p. 2-15.
Hamel, Katht, Parsons, Jenifer, Boule, Marck, Feldman, Sharon, Wertz, Ingrid, and Zempke, Lizzie, 2001, An aquatic plant identification manual for Washington's freshwater plants: Washington State Department of Ecology, publication no. 01-10-032, $195 \mathrm{p}$.

Hill, B.H., Hall, R.K., Husby, P., Herlihy, A.T., and Dunne, M., 2000, Interregional comparisons of sediment microbial respiration in streams: Freshwater Biology, v. 44, p. 213-222.

Hilldale, R.C., and Mooney, D.M., 2007, Identifying stream habitat features with a two-dimensional hydraulic model - A component of the Yakima River basin water storage feasibility study, Washington: Bureau of Reclamation Technical Series no. TS-YSS-12, 33 p.

Horn, C., 1983, The annual growth cycle of Heteranthera dubia in Ohio: The Michigan Botanist, p. 29-34.

Horner, R.R., Welch, E.B., and Veenstra, R.B., 1983, Development of nuisance periphytic algae in laboratory streams in relation to enrichment and velocity, in Wetzel, R.G., ed., Periphyton of freshwater ecosystems: Proceedings of the first international workshop on periphyton of freshwater ecosystems, Växjö, Sweden, September 14-17, 1982, Dr. W. Junk Publishers, p. 121-134.

Izagirre, Oihana, Agirre, Urko, Bermejo, Miren, Pozo, Jesu, and Elosegi, Arturo, 2008, Environmental controls of whole-stream metabolism identified from continuous monitoring of Basque streams: Journal of the North American Benthological Society, v. 27, no. 2, p. 252-268.

Kaenel, B.R., Buehrer, H., and Uehlinger, U., 2000, Effects of aquatic plant management on stream metabolism and oxygen balance in streams: Freshwater Biology, v. 45, p. $85-95$.

Kinnison, H.B., and Sceva, J.E., 1963, Effects of hydraulic and geologic factors on streamflow of the Yakima River Basin, Washington: U.S. Geological Survey Water-Supply Paper 1595, $134 \mathrm{p}$.

McFarland, Anne, Kiesling, R.L., and Back, J.S., 2004, Using periphytometers to evaluate impairment due to nutrient enrichment: Stephenville, Tex., Texas Institute for Applied Environmental Research, Tarleton State University, 51 p.

Madsen, J.D., 1988, The nutrient dynamics of a submersed macrophyte community in a stream ecosystem dominated by Potamogeton pectinus L.: Journal of Freshwater Ecology, v. 4, p. 541-550. 
Madsen, J.D., Chambers, P.A., James, W.F., Koch, E.W., and Westlake, D.F., 2001, The interaction between water movement, sediment dynamics, and submersed macrophytes: Hydrobiologia, v. 444, p. 71-84.

Maltlock, M.D., Matlock, M.E., Storm, D.E., Smolen, M.D., and Henley, W.J., 1998, Limiting nutrient determination in lotic ecosystems using a quantitative nutrient enrichment periphytometer: Journal of the American Water Resources Association, v. 34, no. 5, p. 1141-1147.

Morace, J.L., Fuhrer, G.J., Rinella, J.F., McKenzie, S.W., and others, 1999, Surface-water-quality assessment of the Yakima River basin in Washington-Overview of major findings, 1987-91: U.S. Geological Survey WaterResources Investigations Report 98-4113, 119 p.

Moulton, S.R., Kennen, J.G., Goldstein, R.M., and Hambrook, J.A., 2002, Revised protocols for sampling algal, invertebrate, and fish communities as part of the national water-quality assessment program: U.S. Geological Survey Open-File Report 02-150, 75 p.

Mueller, D.K., and Spahr, N.E., 2006, Nutrients in streams and rivers across the Nation-1992-2001: U.S. Geological Survey Scientific Investigations Report 2006-5107, 44 p.

National Marine Fisheries Service, 2008, Middle Columbia Steelhead Distinct Population Segment: Northwest Regional Office, National Oceanic and Atmospheric Administration, accessed March 17, at http://www.nwr.noaa.gov/ESASalmon-Listings/Salmon-Populations/Steelhead/STMCR. $\underline{\mathrm{cfm}}$

Odum, H.T., 1956, Primary production in flowing waters: Limnology and Oceanography, v. 1, no. 2, p. 102-117.

Oregon Administrative Code, 2006, Water quality standardsBeneficial uses, policies, and criteria for Oregon: Salem, Oreg., Oregon Secretary of State, Chapter 340-041-0019, accessed July 25, 2008, at http://arcweb.sos.state.or.us/rules/ OARs 300/OAR_340/340 041.html

Phillips, S.W., Focazio, M.J., and Bachman, L.J., 1999, Discharge, nitrate load, and residence time of ground water in the Chesapeake Bay watershed: U.S. Geological Survey Fact Sheet FS-150-99, 6 p.

Rinella, J.F., McKenzie, S.W., Crawford, J.K., Foreman, W.T., Gates, P.M., Fuhrer, G.J., and Janet, M.L., 1992, Surfacewater-quality assessment of the Yakima River basin, Washington: Pesticide and other trace-organic-compound data for water, sediment, soil, and aquatic biota, 1987-91: U.S. Geological Survey Open-File Report 92-644, 154 p.
Rinella, J.F., McKenzie, S.W., and Fuhrer, G.J., 1992, Surface-water-quality assessment of the Yakima River Basin, Washington: Analysis of available water-quality data through 1985 water year: U.S. Geological Survey Open File Report 91-453, 244 p.

Rodriguez, A.D., and Matlock, M.D., 2008, Measuring variability in trophic status in the Lake Waco/Bosque River Watershed: Journal of Biological Engineering, v. 2, no. 1.

Shepherd, Barry, Harper, David, and Millington, Andrew, 1999, Modeling catchment-scale nutrient transport to watercourses in the U.K: Hydrobiologia, v. 395/396, p. 227-237.

Smart, R.M., Dick, G.O., and Snow, J.R., 2005, Update to the Propagation and Establishment of Aquatic Plants Handbook: Washington, U.S. Army Corps of Engineers, $44 \mathrm{p}$.

Steinman, A.D., 1996, Effects of grazers on freshwater benthic algae, in Stevenson, J.R., Bothwell, M.L., and Lowe, R.L., eds., Algal Ecology_Freshwater Benthic Ecosystems: San Diego, Calif., Academic Press, Inc., p. 343-373.

Stevenson, R.J., 1997, Resource thresholds and stream ecosystem sustainability: Journal of the North American Benthological Society, v. 16, no. 2, p. 410-424.

Sumioka, S.S., 1998, A survey of ground-water quality in the Toppenish Creek basin, Yakama Indian Reservation, Washington, 1989-91: U.S. Geological Survey WaterResources Investigations Report 97-4194, 89 p.

Thyssen, N., 1982, Aspects of the oxygen dynamics of a macrophytes dominated lowland stream, in Symoens, J.J., Hooper, S.S., and Compere, P., eds., Studies on Aquatic Vascular Plants: Brussels, Royal Botanical Society of Belgium, p. 202-213.

U.S. Environmental Protection Agency, 2000a, Nutrient criteria technical guidance manual-River and streams: U.S. Environmental Protection Agency report 822-B-00002, $253 \mathrm{p}$.

U.S. Environmental Protection Agency, 2000b, Ambient water quality criteria recommendations - Information supporting the development of State and Tribal nutrient criteria, rivers and streams in Nutrient Ecoregion III: U.S. Environmental Protection Agency, Office of Water, EPA 822-B-00-016, $86 \mathrm{p}$.

U.S. Geological Survey, variously dated, National field manual for the collection of water-quality data: U.S. Geological Survey Techniques of Water-Resources Investigations, book 9, chaps. A1-A9, available at http://water.usgs.gov/owq/ FieldManual/. 
U.S. Geological Survey, 1998, National water information system: U.S. Geological Survey Fact Sheet FS-027-98, 2 p., available at http://pubs.usgs.gov/fs/FS-027-98/.

U.S. Geological Survey, 2002, USGS Data Grapher, Yakima basin: U.S. Geological Survey graphing utility web site, accessed July 25, 2008, at http://or.water.usgs.gov/cgi-bin/ grapher/graph setup.pl

U.S. Geological Survey, 2004, Nutrients, aquatic plant growth, and $\mathrm{pH}$ and dissolved oxygen levels in the Lower Yakima River, Washington: accessed September 30, 2008, at http:// or.water.usgs.gov/projs dir/yakima nutrients/

Voss, F.D., Curran, C.A., and Mastin, M.C., 2008, Modeling water temperature in the Yakima River, Washington, from Roza Diversion Dam to Prosser Dam, 2005-06: U.S. Geological Survey Scientific Investigations Report 20085070,42 p.

Wagner, R.J., Boulger, R.W., Jr., Oblinger, C.J., and Smith, B.A., 2006, Guidelines and standard procedures for continuous water-quality monitors-Station operation, record computation, and data reporting: U.S. Geological Survey Techniques and Methods 1-D3, 51 p. and 8 attachments.

Walpole, R.E., Myers, R.H., Myers, S.L., and Ye, K., 2007, Probability and Statistics for Engineers and Scientists: Upper Saddle River, N.J., Pearson Prentice Hall, 816 p.

Washington Administrative Code, 2006, Water quality standards for surface water of the State of Washington, Chapter 173-201A: accessed April 1, 2008, at http://www. ecy.wa.gov/pubs/wac173201a.pdf

Washington State Department of Ecology, 2007, Environmental information management system: Washington State Department of Ecology web site, accessed December 8, 2008, at http://www.ecy.wa.gov/eim/.
Washington State Department of Ecology, 2008, River and stream water quality monitoring: Washington State Department of Ecology web site, accessed February 28, 2008, at http://www.ecy.wa.gov/programs/eap/fw_riv/ rv main.html

Washington State University, 2007, Washington agricultural weather network: Washington State University web site, accessed December 1, 2007, at http://weather.wsu.edu/.

Webster, J.R., and Swank, W.T., 1985, Within-stream factors affecting nutrient transport from forested and logged watersheds, in Blackmon, B.G., ed., Proceedings of forestry and water quality-A mid-South symposium: Fayetteville, University of Arkansas Department of Forest Resources, p. $18-41$.

Welch, E.B., Horner, R.R., and Patmont, C.R., 1989, Prediction of nuisance periphytic biomass - A management approach: Water Research, v. 23, no. 4, 401-405.

Welch, E.B., Jacoby, J.M., Horner, R.R., and Seeley, M.R., 1988, Nuisance biomass levels of periphytic algae in streams: Hydrobiologia, v. 157, p. 161-168.

Wise, D.R., Rinella, F.A., Rinella, J.F., Embrey, S.S., and Clark, G.M., 2007, Nutrient and suspended-sediment transport and trends in the Columbia River and Puget Sound basins, 1993-2003: U.S. Geological Survey WaterResources Investigations Report 2007-5186, 115 p.

YSI Environmental, 2008: YSI Incorporated, accessed July 1, at https://www.ysi.com/.

Zuroske, M.L., 2006, Water quality in Sulphur Creek Wasteway and Granger Drain, 1997 to 2004: Sunnyside, Wash., South Yakima Conservation District, 33 p. 
Table 15. Data collection activities and site locations in the lower Yakima River basin, Washington, 2004-07.

[Field parameters include water temperature $\left({ }^{\circ} \mathrm{C}\right)$, specific conductance $(\mu \mathrm{s} / \mathrm{cm})$, dissolved oxygen $(\mathrm{mg} / \mathrm{L})$, and $\mathrm{pH}$ (standard units). Shading indicates that measurement was made. Abbreviations: USGS, U.S. Geological Survey; RM, river mile; WWTP, wastewater treatment plant]

\begin{tabular}{|c|c|c|c|c|c|c|c|c|c|c|c|c|c|c|c|c|c|c|c|}
\hline \multirow[b]{4}{*}{ Reach } & \multirow[b]{4}{*}{$\begin{array}{c}\text { USGS site } \\
\text { identification No. }\end{array}$} & \multirow[b]{4}{*}{ Site name } & \multirow[b]{4}{*}{$\begin{array}{l}\text { River } \\
\text { mile }\end{array}$} & \multicolumn{16}{|c|}{ Discrete measurements } \\
\hline & & & & \multicolumn{16}{|c|}{2004} \\
\hline & & & & \multicolumn{5}{|c|}{ Plants } & \multicolumn{6}{|c|}{ Water quality } & \multicolumn{4}{|c|}{ Physical } & \multirow[b]{2}{*}{ · } \\
\hline & & & & 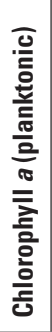 & 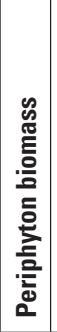 & 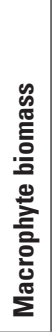 & 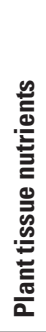 & 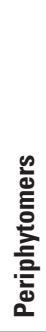 & 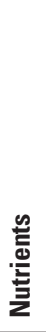 & 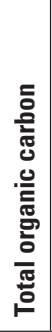 & 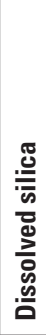 & 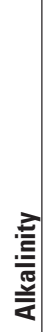 & 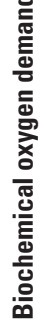 & 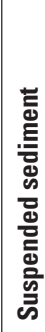 & 근 & 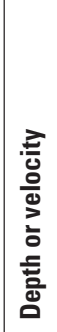 & 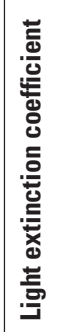 & $\begin{array}{l}\text { 를 } \\
\text { 总 } \\
\text { 를 }\end{array}$ & \\
\hline \multirow[t]{2}{*}{ Naches } & 12494450 & Naches River at RM 12.2 near Naches & 12.2 & & & & & & & & & & & & & & & & \\
\hline & 12498690 & $\begin{array}{l}\text { Naches River above Diversion Dam near } \\
\text { Yakima }\end{array}$ & 3.5 & & & & & & & & & & & & & & & & \\
\hline \multirow[t]{19}{*}{ Zillah } & 12487000 & $\begin{array}{l}\text { Yakima River at Selah Gap near North } \\
\text { Yakima }\end{array}$ & 117.0 & & & & & & & & & & & & & & & & \\
\hline & 12485002 & Roza Canal at Powerhouse at Yakima & 113.3 & & & & & & & & & & & & & & & & \\
\hline & 12500005 & $\begin{array}{l}\text { Yakima River above Roza Power Return near } \\
\text { Yakima }\end{array}$ & 113.0 & & & & & & & & & & & & & & & & \\
\hline & 12500100 & Yakima River at Birchfield Road near Yakima & 111.3 & & & & & & & & & & & & & & & & \\
\hline & 463447120275200 & Yakima WWTP & 111.0 & & & & & & & & & & & & & & & & \\
\hline & 12500445 & Wide Hollow Creek near Mouth at Union Gap & 107.4 & & & & & & & & & & & & & & & & \\
\hline & 12500420 & $\begin{array}{l}\text { Moxee Drain at Birchfield Road near Union } \\
\text { Gap }\end{array}$ & 107.3 & & & & & & & & & & & & & & & & \\
\hline & 12500450 & $\begin{array}{l}\text { Yakima River above Ahtanum Creek at Union } \\
\text { Gap }\end{array}$ & 107.3 & & & & & & & & & & & & & & & & \\
\hline & 12505060 & Yakima River at RM 102.6 near Parker & 102.6 & & & & & & & & & & & & & & & & \\
\hline & 12505100 & $\begin{array}{l}\text { Yakima River at Donald Rd at RM 100.3, at } \\
\text { Donald }\end{array}$ & 100.3 & & & & & & & & & & & & & & & & \\
\hline & 12505085 & Yakima River at RM 100.8 near Donald & 100.8 & & & & & & & & & & & & & & & & \\
\hline & 12505090 & Yakima River at RM 100.7 near Donald & 100.7 & & & & & & & & & & & & & & & & \\
\hline & 12505180 & $\begin{array}{l}\text { Roza Canal Wasteway No. } 3 \text { below Hwy } 12 \\
\text { near Sawyer }\end{array}$ & 98.0 & & & & & & & & & & & & & & & & \\
\hline & 12505270 & Yakima River at RM 94.4 near Buena & 95.0 & & & & & & & & & & & & & & & & \\
\hline & 12505300 & Yakima River near Toppenish & 93.1 & & & & & & & & & & & & & & & & \\
\hline & 12505310 & $\begin{array}{l}\text { Yakima River below Highway } 22 \text { near Top- } \\
\text { penish }\end{array}$ & 92.0 & & & & & & & & & & & & & & & & \\
\hline & 12505320 & Yakima River at RM 91 at Zillah & 91.2 & & & & & & & & & & & & & & & & \\
\hline & 1250532100 & $\begin{array}{l}\text { Yakima River below North Myers Road } \\
\text { Bridge right bank near Zillah }\end{array}$ & 91.0 & & & & & & & & & & & & & & & & \\
\hline & 1250532110 & $\begin{array}{l}\text { Yakima River below North Myers Road } \\
\text { Bridge left bank near Zillah }\end{array}$ & 91.0 & & & & & & & & & & & & & & & & \\
\hline
\end{tabular}


Table 15. Data collection activities and site locations in the lower Yakima River basin, Washington, 2004-07.—Continued

[Field parameters include water temperature $\left({ }^{\circ} \mathrm{C}\right)$, specific conductance $(\mu \mathrm{s} / \mathrm{cm})$, dissolved oxygen $(\mathrm{mg} / \mathrm{L})$, and $\mathrm{pH}$ (standard units). Shading indicates that measurement was made. Abbreviations: USGS, U.S. Geological Survey; RM, river mile; WWTP, wastewater treatment plant]

\begin{tabular}{|c|c|c|c|c|c|c|c|c|c|c|c|c|c|c|c|c|c|c|c|}
\hline \multirow[b]{4}{*}{ Reach } & \multirow[b]{4}{*}{$\begin{array}{c}\text { USGS site } \\
\text { identification No. }\end{array}$} & \multirow[b]{4}{*}{ Site name } & \multirow[b]{4}{*}{$\begin{array}{l}\text { River } \\
\text { mile }\end{array}$} & \multicolumn{16}{|c|}{ Discrete measurements } \\
\hline & & & & \multicolumn{16}{|c|}{2004} \\
\hline & & & & \multicolumn{5}{|c|}{ Plants } & \multicolumn{6}{|c|}{ Water quality } & \multicolumn{4}{|c|}{ Physical } & \multirow[b]{2}{*}{$\mid$} \\
\hline & & & & 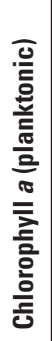 & 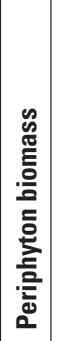 & 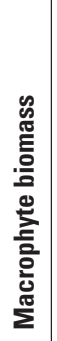 & 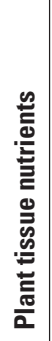 & 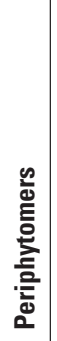 & 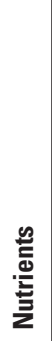 & 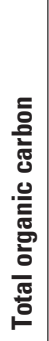 & 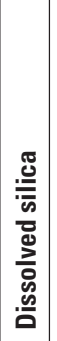 & : & 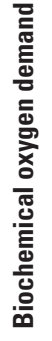 & 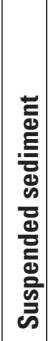 & $\mid \begin{array}{l} \\
3 \\
\frac{0}{4}\end{array}$ & 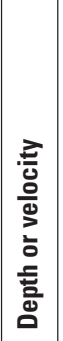 & 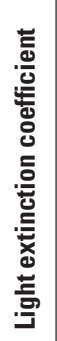 & $\begin{array}{l}\text { 를 } \\
\text { 总 } \\
\text { 尊 }\end{array}$ & \\
\hline \multirow{18}{*}{\begin{tabular}{|l|} 
Zillah- \\
Continued
\end{tabular}} & 1250532120 & Yakima River at RM 90.9 near Zillah & 90.9 & & & & & & & & & & & & & & & & \\
\hline & 1250532170 & Yakima River at RM 90.6 near Zillah & 90.6 & & & & & & & & & & & & & & & & \\
\hline & 1250532300 & Yakima River at RM 89.8 near Zillah & 89.8 & & & & & & & & & & & & & & & & \\
\hline & 1250532340 & Yakima River at RM 89.5 near Zillah & 89.5 & & & & & & & & & & & & & & & & \\
\hline & 462357120153200 & Zillah WWTP & 89.2 & & & & & & & & & & & & & & & & \\
\hline & 1250532400 & $\begin{array}{l}\text { Yakima River } 3 \text { feet from right bank at RM } 89 \\
\text { near Zillah }\end{array}$ & 89.0 & & & & & & & & & & & & & & & & \\
\hline & 1250532410 & $\begin{array}{l}\text { Yakima River } 20 \text { feet from right bank at RM } \\
89 \text { near Zillah }\end{array}$ & 89.0 & & & & & & & & & & & & & & & & \\
\hline & 1250532420 & $\begin{array}{l}\text { Yakima River } 50 \text { feet from right bank at RM } \\
89 \text { near Zillah }\end{array}$ & 89.0 & & & & & & & & & & & & & & & & \\
\hline & 12505325 & Yakima River at RM 88.1 near Toppenish & 88.1 & & & & & & & & & & & & & & & & \\
\hline & 1250532610 & Yakima River at RM 88.0 near Zillah & 88.0 & & & & & & & & & & & & & & & & \\
\hline & 12505350 & $\begin{array}{l}\text { East Toppenish Drain at Wilson Road near } \\
\text { Toppenish }\end{array}$ & 86.0 & & & & & & & & & & & & & & & & \\
\hline & 12505410 & $\begin{array}{l}\text { Sub-Drain No. } 35 \text { at Parton Road near } \\
\text { Granger }\end{array}$ & 83.2 & & & & & & & & & & & & & & & & \\
\hline & 12505440 & Yakima River at Bridge Avenue at Granger & 83.0 & & & & & & & & & & & & & & & & \\
\hline & 12505460 & Granger Drain at mouth near Granger & 82.8 & & & & & & & & & & & & & & & & \\
\hline & 462013120113700 & Granger WWTP & 82.8 & & & & & & & & & & & & & & & & \\
\hline & 12507560 & Coulee Drain at North Satus Road near Satus & 77.0 & & & & & & & & & & & & & & & & \\
\hline & 12507580 & $\begin{array}{l}\text { Yakima River above Satus Creek at RM } 73 \\
\text { near Satus }\end{array}$ & 73.0 & & & & & & & & & & & & & & & & \\
\hline & 12507584 & Yakima River at Murray Road near Sunnyside & 72.0 & & & & & & & & & & & & & & & & \\
\hline \multirow[t]{5}{*}{ Mabton } & 12508620 & Satus Creek at gaging station at Satus & 69.6 & & & & & & & & & & & & & & & & \\
\hline & 12508680 & $\begin{array}{l}\text { Yakima River above Sulphur Creek at RM } \\
61.3 \text { near Mabton }\end{array}$ & 61.3 & & & & & & & & & & & & & & & & \\
\hline & 12508850 & Sulphur Creek Wasteway near Sunnyside & 61.0 & & & & & & & & & & & & & & & & \\
\hline & 46140411959180 & Mabton WWTP & 59.5 & & & & & & & & & & & & & & & & \\
\hline & 12509052 & Grandview WWTP & 59.0 & & & & & & & & & & & & & & & & \\
\hline
\end{tabular}


Table 15. Data collection activities and site locations in the lower Yakima River basin, Washington, 2004-07.-Continued

[Field parameters include water temperature $\left({ }^{\circ} \mathrm{C}\right)$, specific conductance $(\mu \mathrm{s} / \mathrm{cm})$, dissolved oxygen $(\mathrm{mg} / \mathrm{L})$, and $\mathrm{pH}$ (standard units). Shading indicates that measurement was made. Abbreviations: USGS, U.S. Geological Survey; RM, river mile; WWTP, wastewater treatment plant]

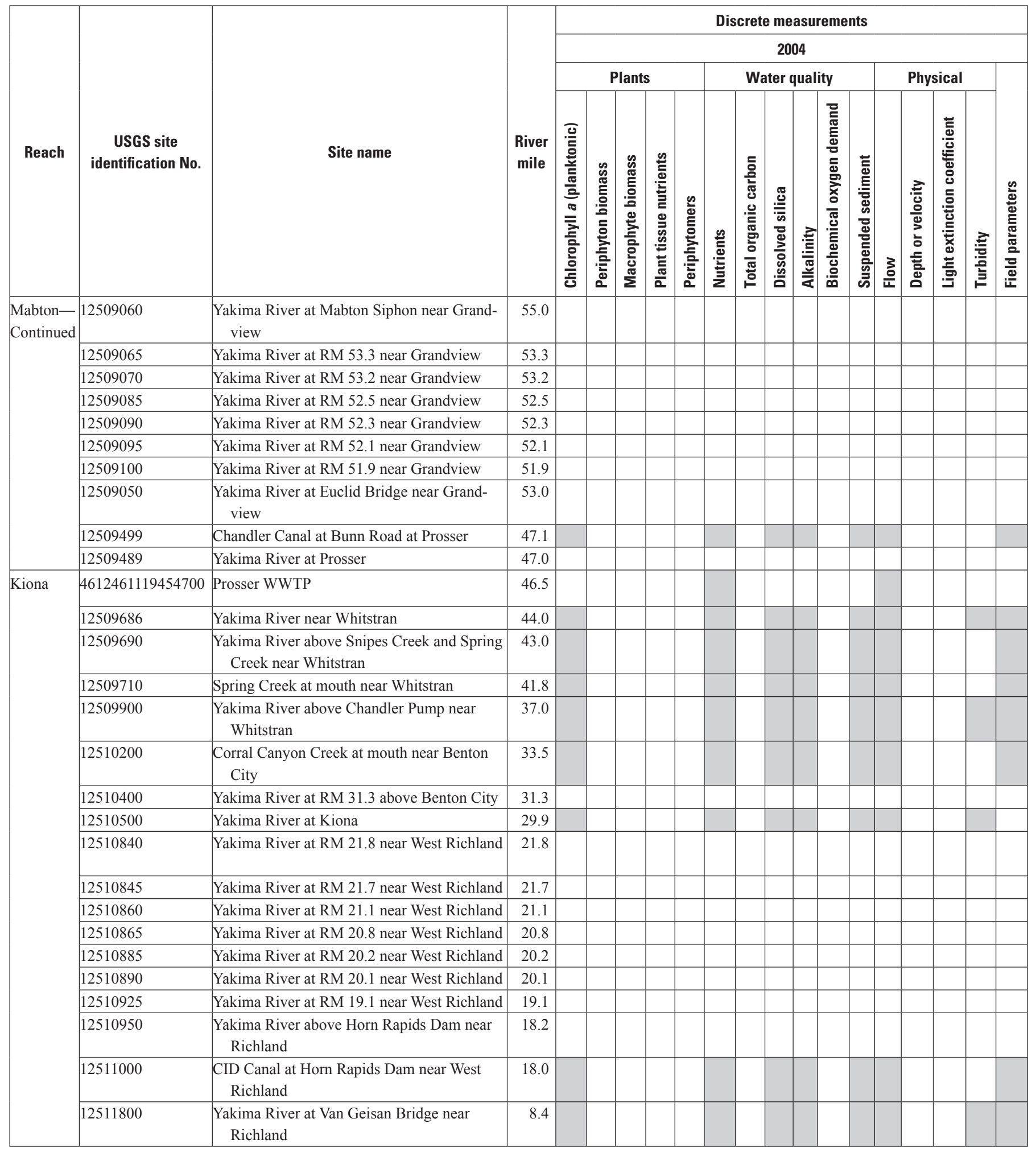


Table 15. Data collection activities and site locations in the lower Yakima River basin, Washington, 2004-07.—Continued

[Field parameters include water temperature $\left({ }^{\circ} \mathrm{C}\right)$, specific conductance $(\mu \mathrm{s} / \mathrm{cm})$, dissolved oxygen $(\mathrm{mg} / \mathrm{L})$, and $\mathrm{pH}$ (standard units). Shading indicates that measurement was made. Abbreviations: USGS, U.S. Geological Survey; RM, river mile; WWTP, wastewater treatment plant]

\begin{tabular}{|c|c|c|c|c|c|c|c|c|c|c|c|c|c|c|c|c|c|c|c|}
\hline \multirow[b]{4}{*}{ Reach } & \multirow[b]{4}{*}{$\begin{array}{l}\text { USGS site } \\
\text { identification No. }\end{array}$} & \multirow[b]{4}{*}{ Site name } & \multirow[b]{4}{*}{$\begin{array}{l}\text { River } \\
\text { mile }\end{array}$} & \multicolumn{16}{|c|}{ Discrete measurements } \\
\hline & & & & \multicolumn{16}{|c|}{2005} \\
\hline & & & & \multicolumn{5}{|c|}{ Plants } & \multicolumn{6}{|c|}{ Water quallity } & \multicolumn{4}{|c|}{ Physical } & \multirow[b]{2}{*}{ 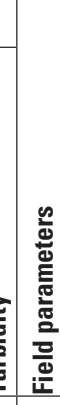 } \\
\hline & & & & 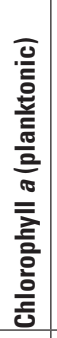 & 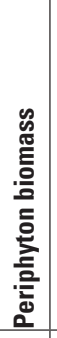 & 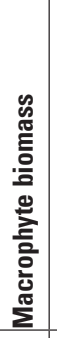 & 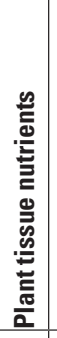 & 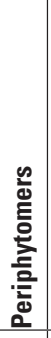 & 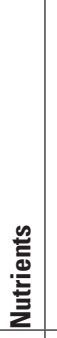 & 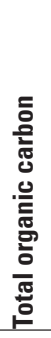 & 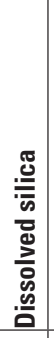 & $\begin{array}{l}\text { 竞 } \\
\text { 恶 } \\
\text { 妾 }\end{array}$ & 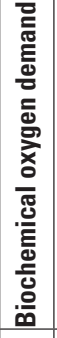 & 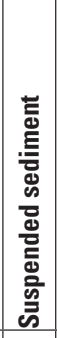 & 交 & 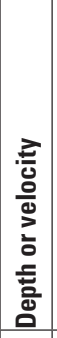 & 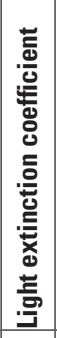 & 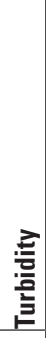 & \\
\hline \multirow[t]{2}{*}{ Naches } & 12494450 & Naches River at RM 12.2 near Naches & 12.2 & & & & & & & & & & & & & & & & \\
\hline & 12498690 & $\begin{array}{l}\text { Naches River above Diversion Dam near } \\
\text { Yakima }\end{array}$ & 3.5 & & & & & & & & & & & & & & & & \\
\hline \multirow{17}{*}{ Zillah } & 12485002 & Roza Canal at Powerhouse at Yakima & 113.3 & & & & & & & & & & & & & & & & \\
\hline & 12500005 & $\begin{array}{l}\text { Yakima River above Roza Power Return near } \\
\text { Yakima }\end{array}$ & 113.0 & & & & & & & & & & & & & & & & \\
\hline & 12500100 & Yakima River at Birchfield Road near Yakima & 111.3 & & & & & & & & & & & & & & & & \\
\hline & 463447120275200 & Yakima WWTP & 111.0 & & & & & & & & & & & & & & & & \\
\hline & 12500445 & Wide Hollow Creek near Mouth at Union Gap & 107.4 & & & & & & & & & & & & & & & & \\
\hline & 12500420 & $\begin{array}{l}\text { Moxee Drain at Birchfield Road near Union } \\
\text { Gap }\end{array}$ & 107.3 & & & & & & & & & & & & & & & & \\
\hline & 12500450 & $\begin{array}{l}\text { Yakima River above Ahtanum Creek at Union } \\
\text { Gap }\end{array}$ & 107.3 & & & & & & & & & & & & & & & & \\
\hline & 12505100 & $\begin{array}{l}\text { Yakima R at Donald Rd at RM 100.3, at } \\
\text { Donald }\end{array}$ & 100.3 & & & & & & & & & & & & & & & & \\
\hline & 12505085 & Yakima River at RM 100.8 near Donald & 100.8 & & & & & & & & & & & & & & & & \\
\hline & 12505090 & Yakima River at RM 100.7 near Donald & 100.7 & & & & & & & & & & & & & & & & \\
\hline & 12505180 & $\begin{array}{l}\text { Roza Canal Wasteway No. } 3 \text { below Hwy } 12 \\
\text { near Sawyer }\end{array}$ & 98.0 & & & & & & & & & & & & & & & & \\
\hline & 12505270 & Yakima River at RM 94.4 near Buena & 95.0 & & & & & & & & & & & & & & & & \\
\hline & 12505300 & Yakima River near Toppenish & 93.1 & & & & & & & & & & & & & & & & \\
\hline & 12505310 & $\begin{array}{l}\text { Yakima River below Highway } 22 \text { near Top- } \\
\text { penish }\end{array}$ & 92.0 & & & & & & & & & & & & & & & & \\
\hline & 12505320 & Yakima River at RM 91 at Zillah & 91.2 & & & & & & & & & & & & & & & & \\
\hline & 1250532100 & $\begin{array}{l}\text { Yakima River below N. Myers Road Bridge } \\
\text { right bank near Zillah }\end{array}$ & 91.0 & & & & & & & & & & & & & & & & \\
\hline & 1250532110 & $\begin{array}{l}\text { Yakima River below N. Myers Road Bridge } \\
\text { left bank near Zillah }\end{array}$ & 91.0 & & & & & & & & & & & & & & & & \\
\hline
\end{tabular}


Table 15. Data collection activities and site locations in the lower Yakima River basin, Washington, 2004-07.-Continued

[Field parameters include water temperature $\left({ }^{\circ} \mathrm{C}\right)$, specific conductance $(\mu \mathrm{s} / \mathrm{cm})$, dissolved oxygen $(\mathrm{mg} / \mathrm{L})$, and $\mathrm{pH}$ (standard units). Shading indicates that measurement was made. Abbreviations: USGS, U.S. Geological Survey; RM, river mile; WWTP, wastewater treatment plant]

\begin{tabular}{|c|c|c|c|c|c|c|c|c|c|c|c|c|c|c|c|c|c|c|c|}
\hline \multirow[b]{4}{*}{ Reach } & \multirow[b]{4}{*}{$\begin{array}{c}\text { USGS site } \\
\text { identification No. }\end{array}$} & \multirow[b]{4}{*}{ Site name } & \multirow[b]{4}{*}{$\begin{array}{l}\text { River } \\
\text { mile }\end{array}$} & \multicolumn{16}{|c|}{ Discrete measurements } \\
\hline & & & & \multicolumn{16}{|c|}{2005} \\
\hline & & & & \multicolumn{5}{|c|}{ Plants } & \multicolumn{6}{|c|}{ Water quallity } & \multicolumn{4}{|c|}{ Physical } & \multirow[b]{2}{*}{ 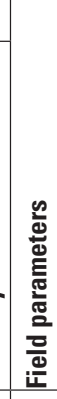 } \\
\hline & & & & 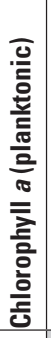 & 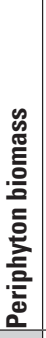 & 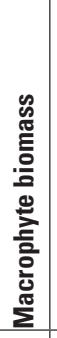 & 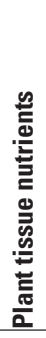 & 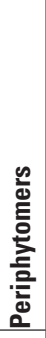 & 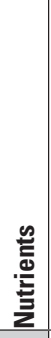 & 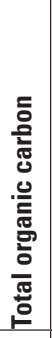 & 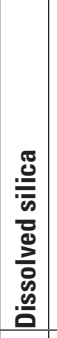 & 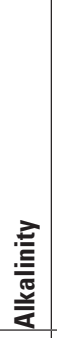 & 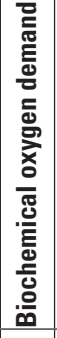 & 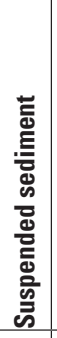 & 흔 & 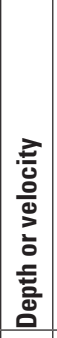 & 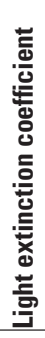 & 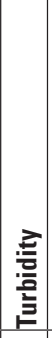 & \\
\hline Zillah- & 1250532120 & Yakima River at RM 90.9 near Zillah & 90.9 & & & & & & & & & & & & & & & & \\
\hline \multirow[t]{17}{*}{ Continued } & 1250532170 & Yakima River at RM 90.6 near Zillah & 90.6 & & & & & & & & & & & & & & & & \\
\hline & 1250532300 & Yakima River at RM 89.8 near Zillah & 89.8 & & & & & & & & & & & & & & & & \\
\hline & 1250532340 & Yakima River at RM 89.5 near Zillah & 89.5 & & & & & & & & & & & & & & & & \\
\hline & 462357120153200 & Zillah WWTP & 89.2 & & & & & & & & & & & & & & & & \\
\hline & 1250532400 & $\begin{array}{l}\text { Yakima River } 3 \text { feet from right bank at RM } \\
89 \text { near Zillah }\end{array}$ & 89.0 & & & & & & & & & & & & & & & & \\
\hline & 1250532410 & $\begin{array}{l}\text { Yakima River } 20 \text { feet from right bank at RM } \\
89 \text { near Zillah }\end{array}$ & 89.0 & & & & & & & & & & & & & & & & \\
\hline & 1250532420 & $\begin{array}{l}\text { Yakima River } 50 \text { feet from right bank at RM } \\
89 \text { near Zillah }\end{array}$ & 89.0 & & & & & & & & & & & & & & & & \\
\hline & 12505325 & Yakima River at RM 88.1 near Toppenish & 88.1 & & & & & & & & & & & & & & & & \\
\hline & 1250532610 & Yakima River at RM 88.0 near Zillah & 88.0 & & & & & & & & & & & & & & & & \\
\hline & 12505350 & $\begin{array}{l}\text { East Toppenish Drain at Wilson Road near } \\
\text { Toppenish }\end{array}$ & 86.0 & & & & & & & & & & & & & & & & \\
\hline & 12505410 & $\begin{array}{l}\text { Sub-Drain No. } 35 \text { at Parton Road near } \\
\text { Granger }\end{array}$ & 83.2 & & & & & & & & & & & & & & & & \\
\hline & 12505440 & Yakima River at Bridge Avenue at Granger & 83.0 & & & & & & & & & & & & & & & & \\
\hline & 12505460 & Granger Drain at mouth near Granger & 82.8 & & & & & & & & & & & & & & & & \\
\hline & 462013120113700 & Granger WWTP & 82.8 & & & & & & & & & & & & & & & & \\
\hline & 12507560 & Coulee Drain at North Satus Road near Satus & 77.0 & & & & & & & & & & & & & & & & \\
\hline & 12507580 & $\begin{array}{l}\text { Yakima River above Satus Creek at RM } 73 \\
\text { near Satus }\end{array}$ & 73.0 & & & & & & & & & & & & & & & & \\
\hline & 12507584 & Yakima River at Murray Road near Sunnyside & 72.0 & & & & & & & & & & & & & & & & \\
\hline \multirow[t]{5}{*}{ Mabton } & 12508620 & Satus Creek at gage at Satus & 69.6 & & & & & & & & & & & & & & & & \\
\hline & 12508680 & $\begin{array}{l}\text { Yakima River above Sulphur Creek at RM } \\
61.3 \text { near Mabton }\end{array}$ & 61.3 & & & & & & & & & & & & & & & & \\
\hline & 12508850 & Sulphur Creek Wasteway near Sunnyside & 61.0 & & & & & & & & & & & & & & & & \\
\hline & 46140411959180 & Mabton WWTP & 59.5 & & & & & & & & & & & & & & & & \\
\hline & 12509052 & Grandview WWTP & 59.0 & & & & & & & & & & & & & & & & \\
\hline
\end{tabular}


Table 15. Data collection activities and site locations in the lower Yakima River basin, Washington, 2004-07.-Continued

[Field parameters include water temperature $\left({ }^{\circ} \mathrm{C}\right)$, specific conductance $(\mu \mathrm{s} / \mathrm{cm})$, dissolved oxygen $(\mathrm{mg} / \mathrm{L})$, and $\mathrm{pH}$ (standard units). Shading indicates that measurement was made. Abbreviations: USGS, U.S. Geological Survey; RM, river mile; WWTP, wastewater treatment plant]

\begin{tabular}{|c|c|c|c|c|c|c|c|c|c|c|c|c|c|c|c|c|c|c|c|}
\hline \multirow[b]{3}{*}{ Reach } & \multirow[b]{3}{*}{$\begin{array}{c}\text { USGS site } \\
\text { identification No. }\end{array}$} & \multirow[b]{3}{*}{ Site name } & \multirow[b]{3}{*}{$\begin{array}{l}\text { River } \\
\text { mile }\end{array}$} & \multicolumn{16}{|c|}{ Discrete measurements } \\
\hline & & & & \multicolumn{5}{|c|}{ Plants } & \multicolumn{6}{|c|}{ Water quallity } & \multicolumn{4}{|c|}{ Physical } & \multirow[b]{2}{*}{ 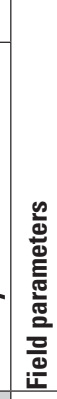 } \\
\hline & & & & 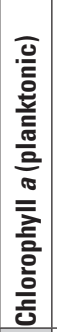 & 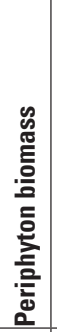 & 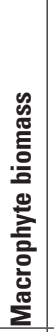 & 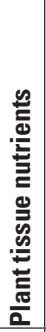 & 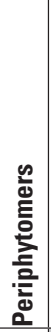 & 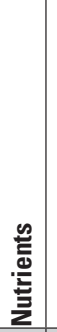 & 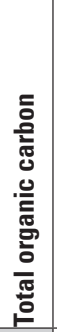 & 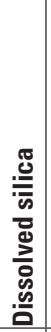 & $\begin{array}{l}\text { 竞 } \\
\text { 严 } \\
\text { 产 } \\
\end{array}$ & 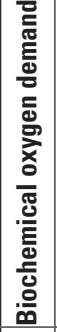 & 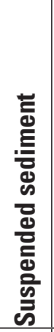 & \begin{tabular}{|l} 
\\
3 \\
$\frac{0}{4}$ \\
\end{tabular} & 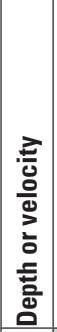 & 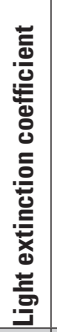 & 章 & \\
\hline \multirow{6}{*}{$\begin{array}{l}\text { Mabton- } \\
\text { Continued }\end{array}$} & 12509060 & $\begin{array}{l}\text { Yakima River at Mabton Siphon near Grand- } \\
\text { view }\end{array}$ & 55.0 & & & & & & & & & & & & & & & & \\
\hline & 12509095 & Yakima River at RM 52.1 near Grandview & 52.1 & & & & & & & & & & & & & & & & \\
\hline & 12509100 & Yakima River at RM 51.9 near Grandview & 51.9 & & & & & & & & & & & & & & & & \\
\hline & 12509050 & $\begin{array}{l}\text { Yakima River at Euclid Bridge near Grand- } \\
\text { view }\end{array}$ & 53.0 & & & & & & & & & & & & & & & & \\
\hline & 12509499 & Chandler Canal at Bunn Road at Prosser & 47.1 & & & & & & & & & & & & & & & & \\
\hline & 12509489 & Yakima River at Prosser & 47.0 & & & & & & & & & & & & & & & & \\
\hline \multirow[t]{17}{*}{ Kiona } & 4612461119454700 & Prosser WWTP & 46.5 & & & & & & & & & & & & & & & & \\
\hline & 12509686 & Yakima River near Whitstran & 44.0 & & & & & & & & & & & & & & & & \\
\hline & 12509690 & $\begin{array}{l}\text { Yakima River above Snipes Creek and Spring } \\
\text { Creek near Whitstran }\end{array}$ & 43.0 & & & & & & & & & & & & & & & & \\
\hline & 12509900 & $\begin{array}{l}\text { Yakima River above Chandler Pump near } \\
\text { Whitstran }\end{array}$ & 37.0 & & & & & & & & & & & & & & & & \\
\hline & 12510200 & $\begin{array}{l}\text { Corral Canyon Creek at mouth near Benton } \\
\text { City }\end{array}$ & 33.5 & & & & & & & & & & & & & & & & \\
\hline & 12510400 & Yakima River at RM 31.3 above Benton City & 31.3 & & & & & & & & & & & & & & & & \\
\hline & 12510500 & Yakima River at Kiona & 29.9 & & & & & & & & & & & & & & & & \\
\hline & 12510840 & Yakima River at RM 21.8 near West Richland & 21.8 & & & & & & & & & & & & & & & & \\
\hline & 12510845 & Yakima River at RM 21.7 near West Richland & 21.7 & & & & & & & & & & & & & & & & \\
\hline & 12510860 & Yakima River at RM 21.1 near West Richland & 21.1 & & & & & & & & & & & & & & & & \\
\hline & 12510865 & Yakima River at RM 20.8 near West Richland & 20.8 & & & & & & & & & & & & & & & & \\
\hline & 12510885 & Yakima River at RM 20.2 near West Richland & 20.2 & & & & & & & & & & & & & & & & \\
\hline & 12510890 & Yakima River at RM 20.1 near West Richland & 20.1 & & & & & & & & & & & & & & & & \\
\hline & 12510925 & Yakima River at RM 19.1 near West Richland & 19.1 & & & & & & & & & & & & & & & & \\
\hline & 12510950 & $\begin{array}{l}\text { Yakima River above Horn Rapids Dam near } \\
\text { Richland }\end{array}$ & 18.2 & & & & & & & & & & & & & & & & \\
\hline & 12511000 & $\begin{array}{l}\text { CID Canal at Horn Rapids Dam near West } \\
\text { Richland }\end{array}$ & 18.0 & & & & & & & & & & & & & & & & \\
\hline & 12511800 & $\begin{array}{l}\text { Yakima River at Van Geisan Bridge near } \\
\text { Richland }\end{array}$ & 8.4 & & & & & & & & & & & & & & & & \\
\hline
\end{tabular}


Table 15. Data collection activities and site locations in the lower Yakima River basin, Washington, 2004-07.-Continued

[Field parameters include water temperature $\left({ }^{\circ} \mathrm{C}\right)$, specific conductance $(\mu \mathrm{s} / \mathrm{cm})$, dissolved oxygen $(\mathrm{mg} / \mathrm{L})$, and $\mathrm{pH}$ (standard units). Shading indicates that measurement was made. Abbreviations: USGS, U.S. Geological Survey; RM, river mile; WWTP, wastewater treatment plant]

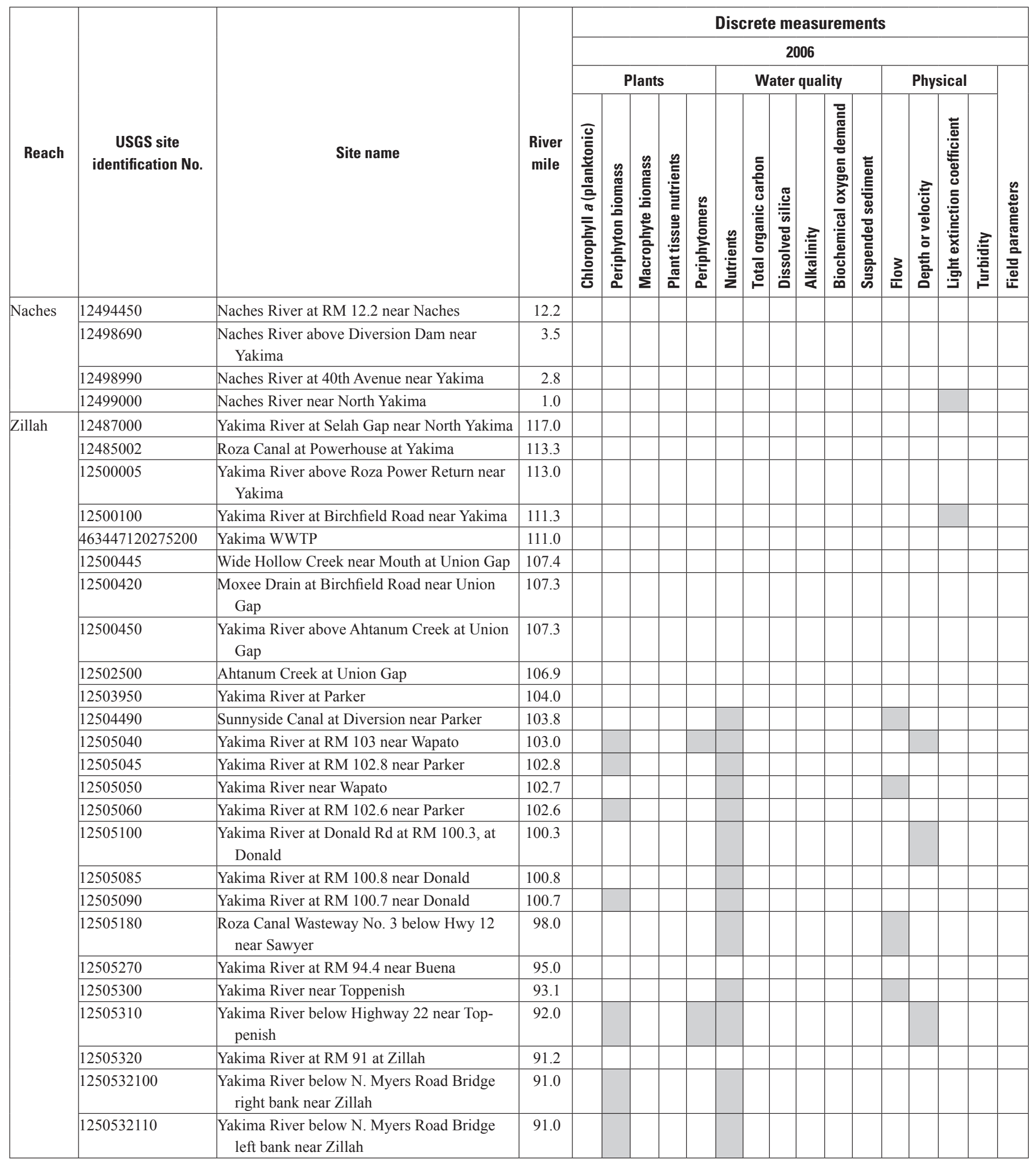


Table 15. Data collection activities and site locations in the lower Yakima River basin, Washington, 2004-07.-Continued

[Field parameters include water temperature $\left({ }^{\circ} \mathrm{C}\right)$, specific conductance $(\mu \mathrm{s} / \mathrm{cm})$, dissolved oxygen $(\mathrm{mg} / \mathrm{L})$, and $\mathrm{pH}$ (standard units). Shading indicates that measurement was made. Abbreviations: USGS, U.S. Geological Survey; RM, river mile; WWTP, wastewater treatment plant]

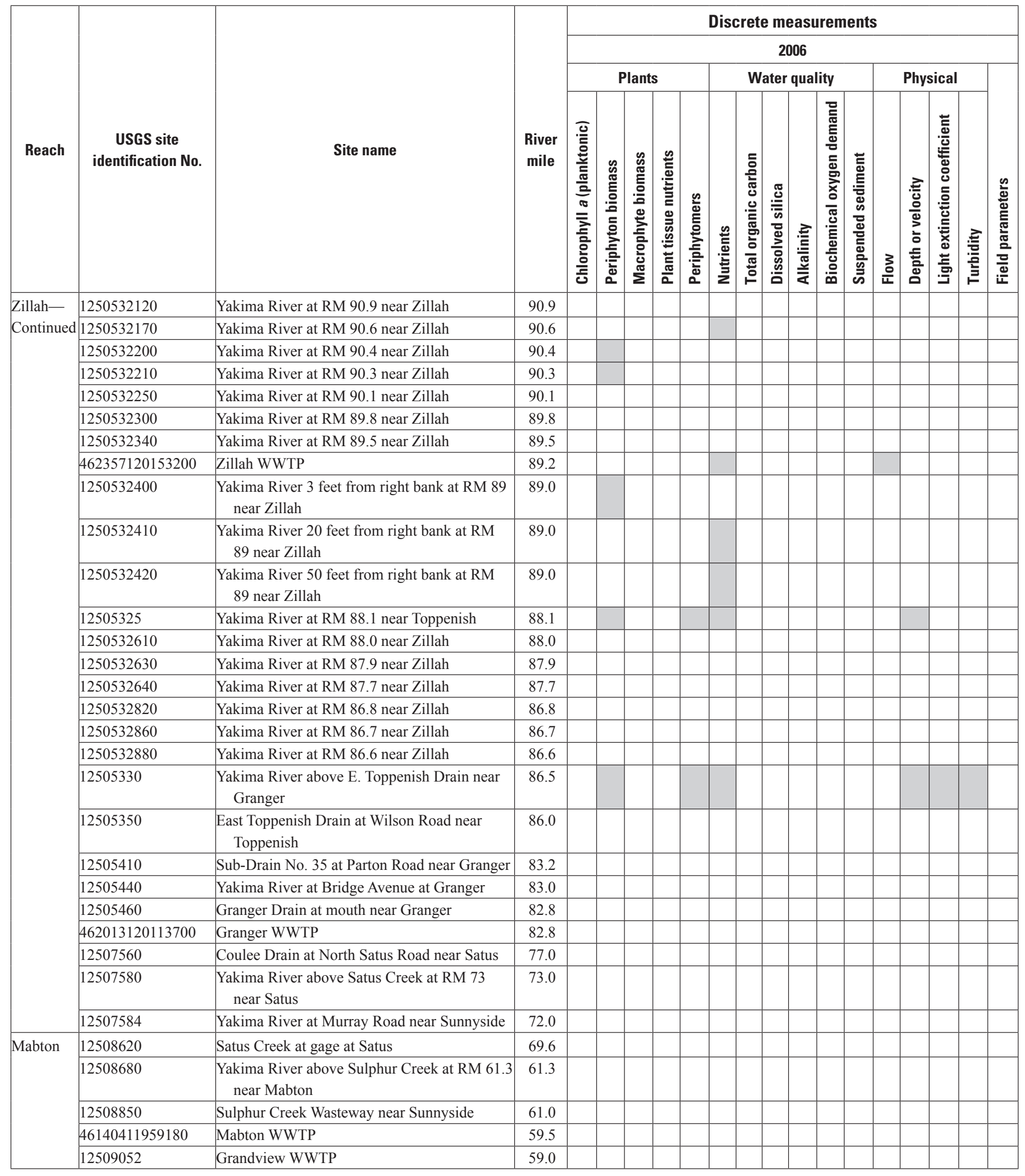


Table 15. Data collection activities and site locations in the lower Yakima River basin, Washington, 2004-07.-Continued

[Field parameters include water temperature $\left({ }^{\circ} \mathrm{C}\right)$, specific conductance $(\mu \mathrm{s} / \mathrm{cm})$, dissolved oxygen $(\mathrm{mg} / \mathrm{L})$, and $\mathrm{pH}$ (standard units). Shading indicates that measurement was made. Abbreviations: USGS, U.S. Geological Survey; RM, river mile; WWTP, wastewater treatment plant]

\begin{tabular}{|c|c|c|c|c|c|c|c|c|c|c|c|c|c|c|c|c|c|c|c|}
\hline \multirow[b]{4}{*}{ Reach } & \multirow[b]{4}{*}{$\begin{array}{c}\text { USGS site } \\
\text { identification No. }\end{array}$} & \multirow[b]{4}{*}{ Site name } & \multirow[b]{4}{*}{$\begin{array}{c}\text { River } \\
\text { mile }\end{array}$} & \multicolumn{16}{|c|}{ Discrete measurements } \\
\hline & & & & \multicolumn{16}{|c|}{2006} \\
\hline & & & & \multicolumn{5}{|c|}{ Plants } & \multicolumn{6}{|c|}{ Water quality } & \multicolumn{4}{|c|}{ Physical } & \multirow[b]{2}{*}{ 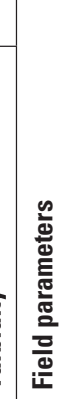 } \\
\hline & & & & 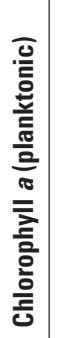 & 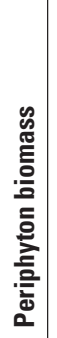 & 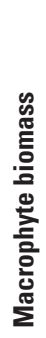 & 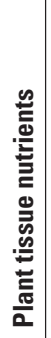 & 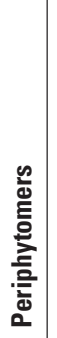 & 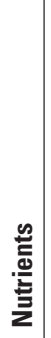 & 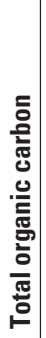 & 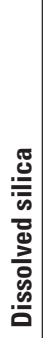 & 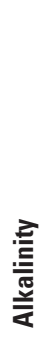 & 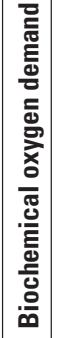 & 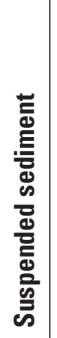 & 흔 & 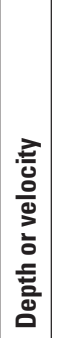 & 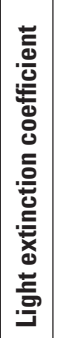 & 童 & \\
\hline \multirow{6}{*}{$\begin{array}{l}\text { Mabton- } \\
\text { Continued } \\
\end{array}$} & 12509060 & $\begin{array}{l}\text { Yakima River at Mabton Siphon near Grand- } \\
\text { view }\end{array}$ & 55.0 & & & & & & & & & & & & & & & & \\
\hline & 12509095 & Yakima River at RM 52.1 near Grandview & 52.1 & & & & & & & & & & & & & & & & \\
\hline & 12509100 & Yakima River at RM 51.9 near Grandview & 51.9 & & & & & & & & & & & & & & & & \\
\hline & 12509050 & Yakima River at Euclid Bridge near Grandview & 53.0 & & & & & & & & & & & & & & & & \\
\hline & 12509499 & Chandler Canal at Bunn Road at Prosser & 47.1 & & & & & & & & & & & & & & & & \\
\hline & 12509489 & Yakima River at Prosser & 47.0 & & & & & & & & & & & & & & & & \\
\hline \multirow[t]{13}{*}{ Kiona } & 4612461119454700 & Prosser WWTP & 46.5 & & & & & & & & & & & & & & & & \\
\hline & 12509686 & Yakima River near Whitstran & 44.0 & & & & & & & & & & & & & & & & \\
\hline & 12509690 & $\begin{array}{l}\text { Yakima River above Snipes Creek and Spring } \\
\text { Creek near Whitstran }\end{array}$ & 43.0 & & & & & & & & & & & & & & & & \\
\hline & 12509710 & Spring Creek at mouth near Whitstran & 41.8 & & & & & & & & & & & & & & & & \\
\hline & 12510845 & Yakima River at RM 21.7 near West Richland & 21.7 & & & & & & & & & & & & & & & & \\
\hline & 12510860 & Yakima River at RM 21.1 near West Richland & 21.1 & & & & & & & & & & & & & & & & \\
\hline & 12510865 & Yakima River at RM 20.8 near West Richland & 20.8 & & & & & & & & & & & & & & & & \\
\hline & 12510885 & Yakima River at RM 20.2 near West Richland & 20.2 & & & & & & & & & & & & & & & & \\
\hline & 12510890 & Yakima River at RM 20.1 near West Richland & 20.1 & & & & & & & & & & & & & & & & \\
\hline & 12510925 & Yakima River at RM 19.1 near West Richland & 19.1 & & & & & & & & & & & & & & & & \\
\hline & 12510950 & $\begin{array}{l}\text { Yakima River above Horn Rapids Dam near } \\
\text { Richland }\end{array}$ & 18.2 & & & & & & & & & & & & & & & & \\
\hline & 12511000 & $\begin{array}{l}\text { CID Canal at Horn Rapids Dam near West } \\
\text { Richland }\end{array}$ & 18.0 & & & & & & & & & & & & & & & & \\
\hline & 12511800 & $\begin{array}{l}\text { Yakima River at Van Geisan Bridge near } \\
\text { Richland }\end{array}$ & 8.4 & & & & & & & & & & & & & & & & \\
\hline
\end{tabular}


Table 15. Data collection activities and site locations in the lower Yakima River basin, Washington, 2004-07.-Continued

[Field parameters include water temperature $\left({ }^{\circ} \mathrm{C}\right)$, specific conductance $(\mu \mathrm{s} / \mathrm{cm})$, dissolved oxygen $(\mathrm{mg} / \mathrm{L})$, and $\mathrm{pH}$ (standard units). Shading indicates that measurement was made. Abbreviations: USGS, U.S. Geological Survey; RM, river mile; WWTP, wastewater treatment plant]

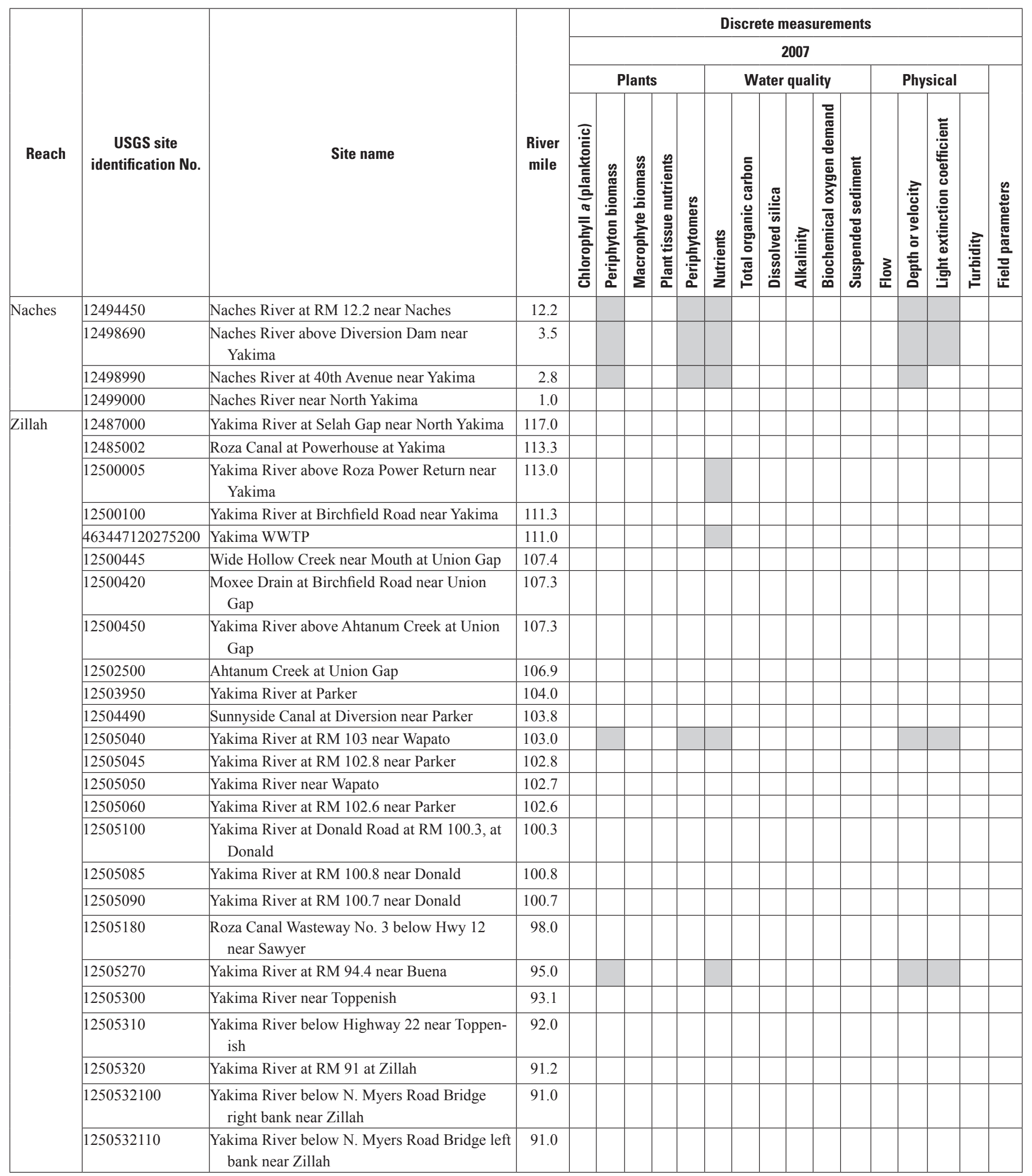


Table 15. Data collection activities and site locations in the lower Yakima River basin, Washington, 2004-07.-Continued

[Field parameters include water temperature $\left({ }^{\circ} \mathrm{C}\right)$, specific conductance $(\mu \mathrm{s} / \mathrm{cm})$, dissolved oxygen $(\mathrm{mg} / \mathrm{L})$, and $\mathrm{pH}$ (standard units). Shading indicates that measurement was made. Abbreviations: USGS, U.S. Geological Survey; RM, river mile; WWTP, wastewater treatment plant]

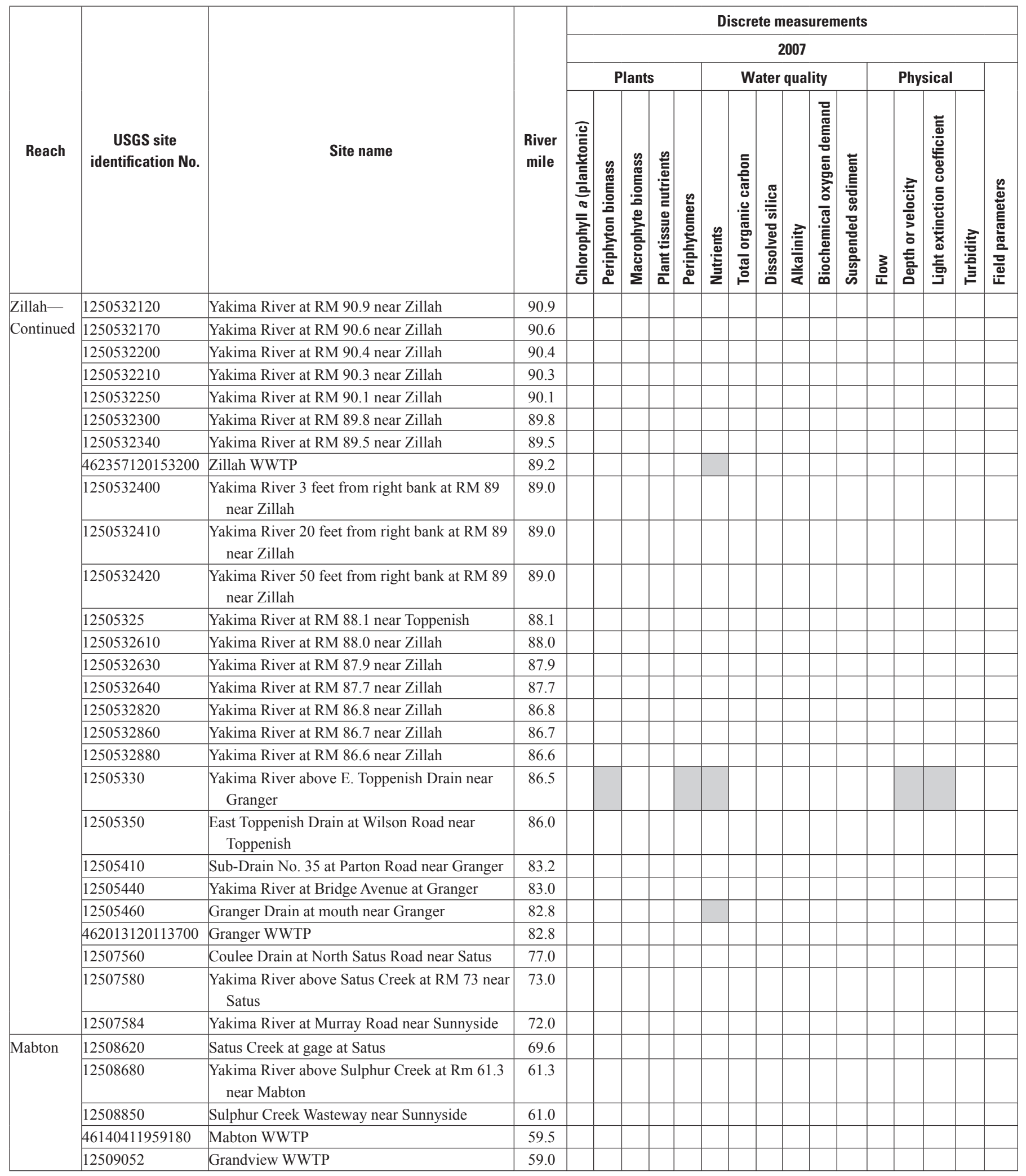


Table 15. Data collection activities and site locations in the lower Yakima River basin, Washington, 2004-07.—Continued

[Field parameters include water temperature $\left({ }^{\circ} \mathrm{C}\right)$, specific conductance $(\mu \mathrm{s} / \mathrm{cm})$, dissolved oxygen $(\mathrm{mg} / \mathrm{L})$, and $\mathrm{pH}$ (standard units). Shading indicates that measurement was made. Abbreviations: USGS, U.S. Geological Survey; RM, river mile; WWTP, wastewater treatment plant]

\begin{tabular}{|c|c|c|c|c|c|c|c|c|c|c|c|c|c|c|c|c|c|c|c|}
\hline \multirow[b]{4}{*}{ Reach } & \multirow[b]{4}{*}{$\begin{array}{c}\text { USGS site } \\
\text { identification No. }\end{array}$} & \multirow[b]{4}{*}{ Site name } & \multirow[b]{4}{*}{$\begin{array}{l}\text { River } \\
\text { mile }\end{array}$} & \multicolumn{16}{|c|}{ Discrete measurements } \\
\hline & & & & \multicolumn{16}{|c|}{2007} \\
\hline & & & & \multicolumn{5}{|c|}{ Plants } & \multicolumn{6}{|c|}{ Water quality } & \multicolumn{4}{|c|}{ Physical } & \multirow[b]{2}{*}{ 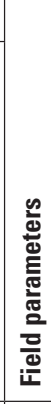 } \\
\hline & & & & 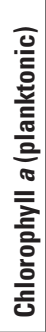 & 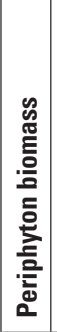 & 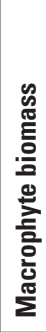 & 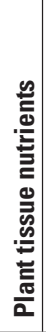 & 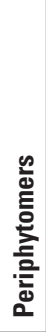 & 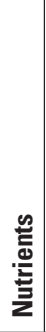 & 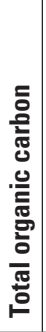 & 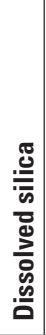 & 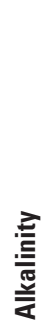 & 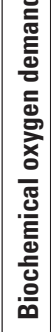 & 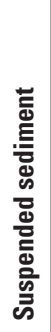 & zo & 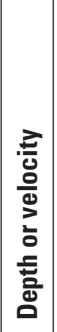 & 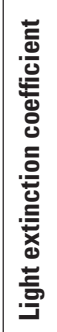 & 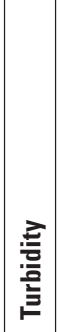 & \\
\hline \multirow{7}{*}{$\begin{array}{l}\text { Mabton- } \\
\text { Continued }\end{array}$} & 12509060 & Yakima River at Mabton Siphon nr Grandview & 55.0 & & & & & & & & & & & & & & & & \\
\hline & 12509065 & Yakima River at RM 53.3 near Grandview & 53.3 & & & & & & & & & & & & & & & & \\
\hline & 12509095 & Yakima River at RM 52.1 near Grandview & 52.1 & & & & & & & & & & & & & & & & \\
\hline & 12509100 & Yakima River at RM 51.9 near Grandview & 51.9 & & & & & & & & & & & & & & & & \\
\hline & 12509050 & Yakima River at Euclid Bridge near Grandview & 53.0 & & & & & & & & & & & & & & & & \\
\hline & 12509499 & Chandler Canal at Bunn Road at Prosser & 47.1 & & & & & & & & & & & & & & & & \\
\hline & 12509489 & Yakima River at Prosser & 47.0 & & & & & & & & & & & & & & & & \\
\hline \multirow[t]{12}{*}{ Kiona } & 4612461119454700 & Prosser WWTP & 46.5 & & & & & & & & & & & & & & & & \\
\hline & 12509686 & Yakima River near Whitstran & 44.0 & & & & & & & & & & & & & & & & \\
\hline & 12509690 & $\begin{array}{l}\text { Yakima River above Snipes Creek and Spring } \\
\text { Creek near Whitstran }\end{array}$ & 43.0 & & & & & & & & & & & & & & & & \\
\hline & 12509710 & Spring Creek at mouth near Whitstran & 41.8 & & & & & & & & & & & & & & & & \\
\hline & 12509900 & $\begin{array}{l}\text { Yakima River above Chandler Pump near } \\
\text { Whitstran }\end{array}$ & 37.0 & & & & & & & & & & & & & & & & \\
\hline & 12510865 & Yakima River at RM 20.8 near West Richland & 20.8 & & & & & & & & & & & & & & & & \\
\hline & 12510885 & Yakima River at RM 20.2 near West Richland & 20.2 & & & & & & & & & & & & & & & & \\
\hline & 12510890 & Yakima River at RM 20.1 near West Richland & 20.1 & & & & & & & & & & & & & & & & \\
\hline & 12510925 & Yakima River at RM 19.1 near West Richland & 19.1 & & & & & & & & & & & & & & & & \\
\hline & 12510950 & $\begin{array}{l}\text { Yakima River above Horn Rapids Dam near } \\
\text { Richland }\end{array}$ & 18.2 & & & & & & & & & & & & & & & & \\
\hline & 12511000 & $\begin{array}{l}\text { CID Canal at Horn Rapids Dam near West } \\
\text { Richland }\end{array}$ & 18.0 & & & & & & & & & & & & & & & & \\
\hline & 12511800 & $\begin{array}{l}\text { Yakima River at Van Geisan Bridge near } \\
\text { Richland }\end{array}$ & 8.4 & & & & & & & & & & & & & & & & \\
\hline
\end{tabular}


Table 15. Data collection activities and site locations in the lower Yakima River basin, Washington, 2004-07.-Continued

[Field parameters include water temperature $\left({ }^{\circ} \mathrm{C}\right)$, specific conductance $(\mu \mathrm{s} / \mathrm{cm})$, dissolved oxygen $(\mathrm{mg} / \mathrm{L})$, and $\mathrm{pH}$ (standard units). Shading indicates that measurement was made. Abbreviations: USGS, U.S. Geological Survey; RM, river mile; WWTP, wastewater treatment plant]

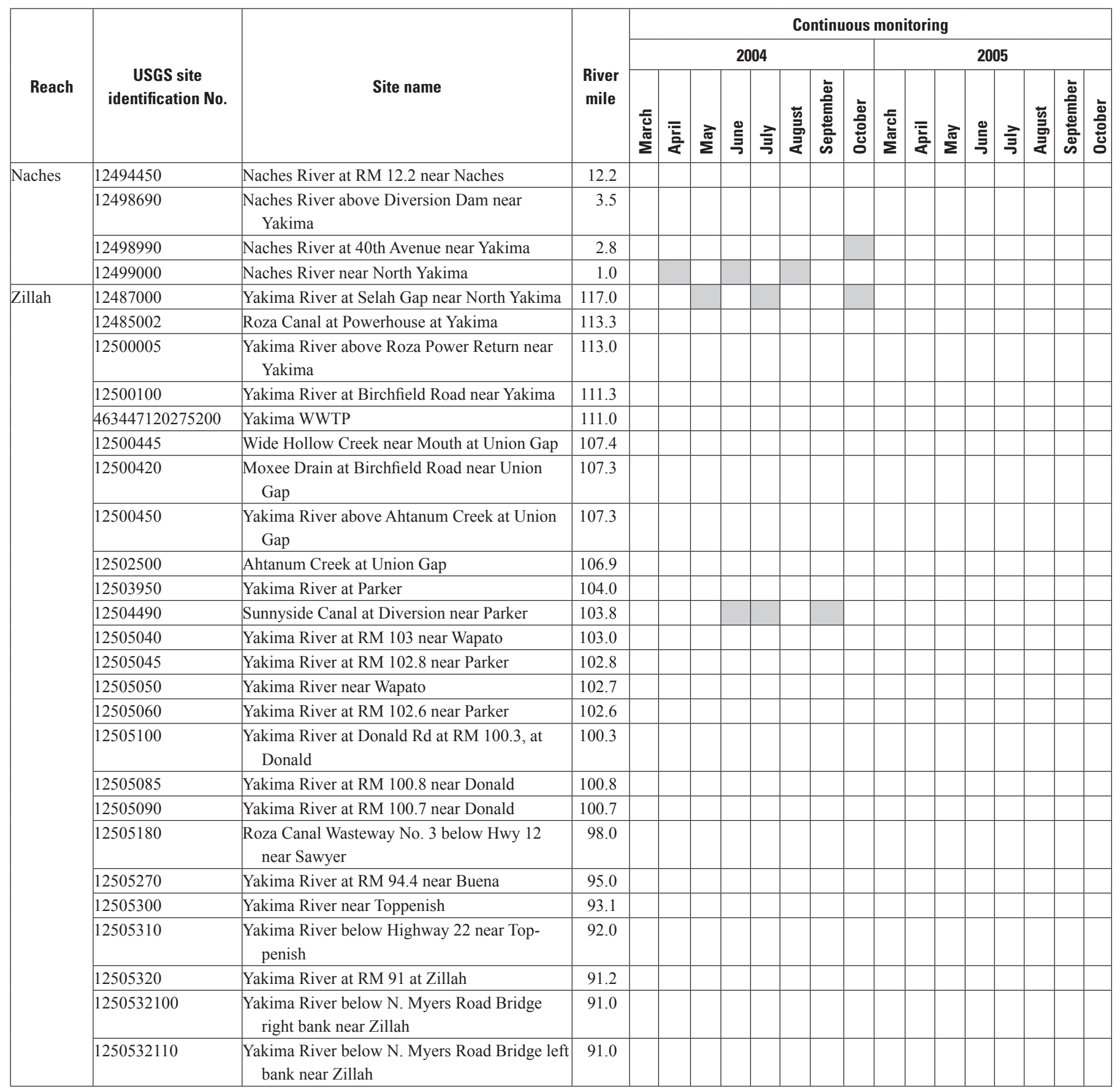


Table 15. Data collection activities and site locations in the lower Yakima River basin, Washington, 2004-07.-Continued

[Field parameters include water temperature $\left({ }^{\circ} \mathrm{C}\right)$, specific conductance $(\mu \mathrm{s} / \mathrm{cm})$, dissolved oxygen $(\mathrm{mg} / \mathrm{L})$, and $\mathrm{pH}$ (standard units). Shading indicates that measurement was made. Abbreviations: USGS, U.S. Geological Survey; RM, river mile; WWTP, wastewater treatment plant]

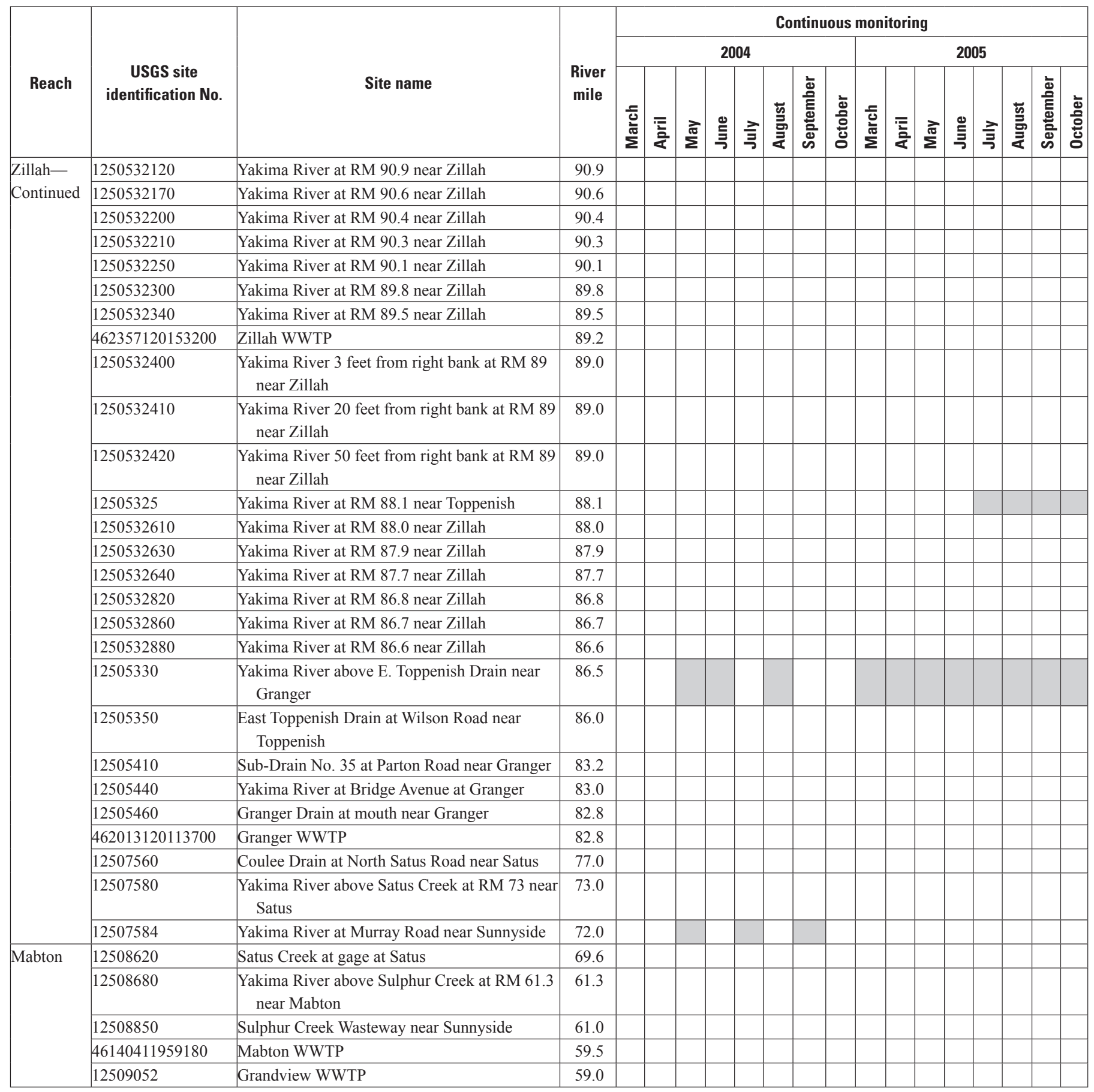


Table 15. Data collection activities and site locations in the lower Yakima River basin, Washington, 2004-07.-Continued

[Field parameters include water temperature $\left({ }^{\circ} \mathrm{C}\right)$, specific conductance $(\mu \mathrm{s} / \mathrm{cm})$, dissolved oxygen $(\mathrm{mg} / \mathrm{L})$, and $\mathrm{pH}$ (standard units). Shading indicates that measurement was made. Abbreviations: USGS, U.S. Geological Survey; RM, river mile; WWTP, wastewater treatment plant]

\begin{tabular}{|c|c|c|c|c|c|c|c|c|c|c|c|c|c|c|c|c|c|c|c|}
\hline \multirow[b]{3}{*}{ Reach } & \multirow{3}{*}{$\begin{array}{c}\text { USGS site } \\
\text { identification No. }\end{array}$} & \multirow[b]{3}{*}{ Site name } & \multirow[b]{3}{*}{$\begin{array}{l}\text { River } \\
\text { mile }\end{array}$} & \multicolumn{16}{|c|}{ Continuous monitoring } \\
\hline & & & & \multicolumn{8}{|c|}{2004} & \multicolumn{8}{|c|}{2005} \\
\hline & & & & 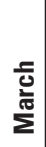 & হ & $\sum^{\frac{\pi}{\pi}}$ & $\stackrel{Ð}{\Xi}$ & 측 & 兽 & 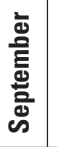 & 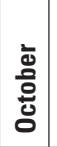 & 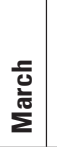 & 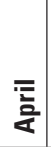 & $\sum^{\frac{\pi}{2}}$ & $\stackrel{\Xi}{5}$ & 극 & 离 & 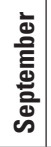 & 홍 \\
\hline \multirow[t]{6}{*}{$\begin{array}{l}\text { Mabton- } \\
\text { Continued }\end{array}$} & 12509060 & $\begin{array}{l}\text { Yakima River at Mabton Siphon near Grand- } \\
\text { view }\end{array}$ & 55.0 & & & & & & & & & & & & & & & & \\
\hline & 12509070 & Yakima River at RM 53.2 near Grandview & 53.2 & & & & & & & & & & & & & & & & \\
\hline & 12509085 & Yakima River at RM 52.5 near Grandview & 52.5 & & & & & & & & & & & & & & & & \\
\hline & 12509090 & Yakima River at RM 52.3 near Grandview & 52.3 & & & & & & & & & & & & & & & & \\
\hline & 12509095 & Yakima River at RM 52.1 near Grandview & 52.1 & & & & & & & & & & & & & & & & \\
\hline & 12509100 & Yakima River at RM 51.9 near Grandview & 51.9 & & & & & & & & & & & & & & & & \\
\hline \multirow{10}{*}{ Kiona } & 12509686 & Yakima River near Whitstran & 44.0 & & & & & & & & & & & & & & & & \\
\hline & 12509690 & $\begin{array}{l}\text { Yakima River above Snipes Creek and Spring } \\
\text { Creek near Whitstran }\end{array}$ & 43.0 & & & & & & & & & & & & & & & & \\
\hline & 12509710 & Spring Creek at mouth near Whitstran & 41.8 & & & & & & & & & & & & & & & & \\
\hline & 12509900 & $\begin{array}{l}\text { Yakima River above Chandler Pump near } \\
\text { Whitstran }\end{array}$ & 37.0 & & & & & & & & & & & & & & & & \\
\hline & 12510200 & $\begin{array}{l}\text { Corral Canyon Creek at mouth near Benton } \\
\text { City }\end{array}$ & 33.5 & & & & & & & & & & & & & & & & \\
\hline & 12510400 & Yakima River at RM 31.3 above Benton City & 31.3 & & & & & & & & & & & & & & & & \\
\hline & 12510500 & Yakima River at Kiona & 29.9 & & & & & & & & & & & & & & & & \\
\hline & 12510840 & Yakima River at RM 21.8 near West Richland & 21.8 & & & & & & & & & & & & & & & & \\
\hline & 12511000 & $\begin{array}{l}\text { CID Canal at Horn Rapids Dam nr West } \\
\text { Richland }\end{array}$ & 18.0 & & & & & & & & & & & & & & & & \\
\hline & 12511800 & $\begin{array}{l}\text { Yakima River at Van Geisan Bridge near } \\
\text { Richland }\end{array}$ & 8.4 & & & & & & & & & & & & & & & & \\
\hline
\end{tabular}


Table 15. Data collection activities and site locations in the lower Yakima River basin, Washington, 2004-07._Continued

[Field parameters include water temperature $\left({ }^{\circ} \mathrm{C}\right)$, specific conductance $(\mu \mathrm{s} / \mathrm{cm})$, dissolved oxygen $(\mathrm{mg} / \mathrm{L})$, and $\mathrm{pH}$ (standard units). Shading indicates that measurement was made. Abbreviations: USGS, U.S. Geological Survey; RM, river mile; WWTP, wastewater treatment plant]

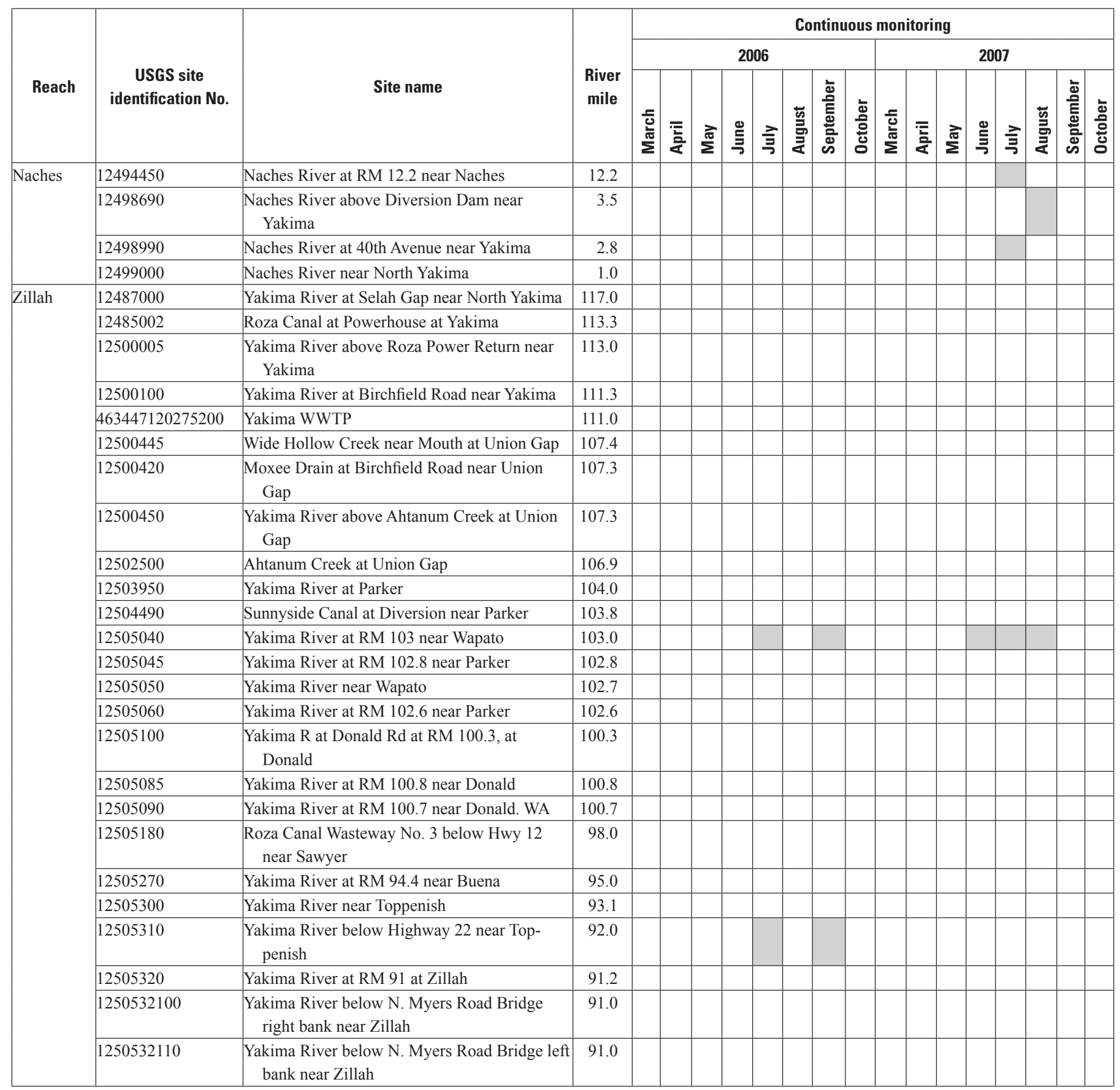


Table 15. Data collection activities and site locations in the lower Yakima River basin, Washington, 2004-07.-Continued

[Field parameters include water temperature $\left({ }^{\circ} \mathrm{C}\right)$, specific conductance $(\mu \mathrm{s} / \mathrm{cm})$, dissolved oxygen $(\mathrm{mg} / \mathrm{L})$, and $\mathrm{pH}$ (standard units). Shading indicates that measurement was made. Abbreviations: USGS, U.S. Geological Survey; RM, river mile; WWTP, wastewater treatment plant]

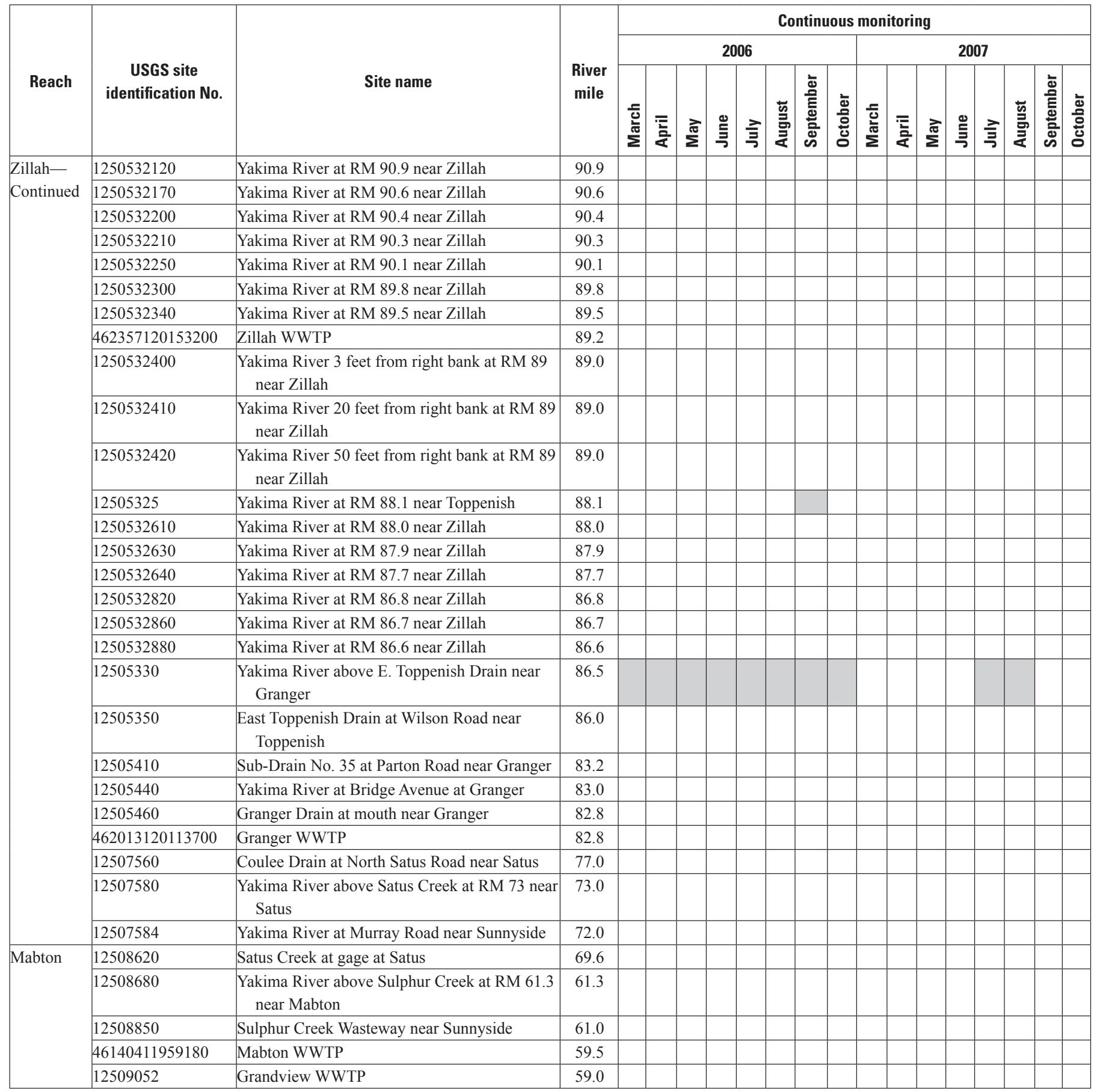


Table 15. Data collection activities and site locations in the lower Yakima River basin, Washington, 2004-07.—Continued

[Field parameters include water temperature $\left({ }^{\circ} \mathrm{C}\right)$, specific conductance $(\mu \mathrm{s} / \mathrm{cm})$, dissolved oxygen $(\mathrm{mg} / \mathrm{L})$, and $\mathrm{pH}$ (standard units). Shading indicates that measurement was made. Abbreviations: USGS, U.S. Geological Survey; RM, river mile; WWTP, wastewater treatment plant]

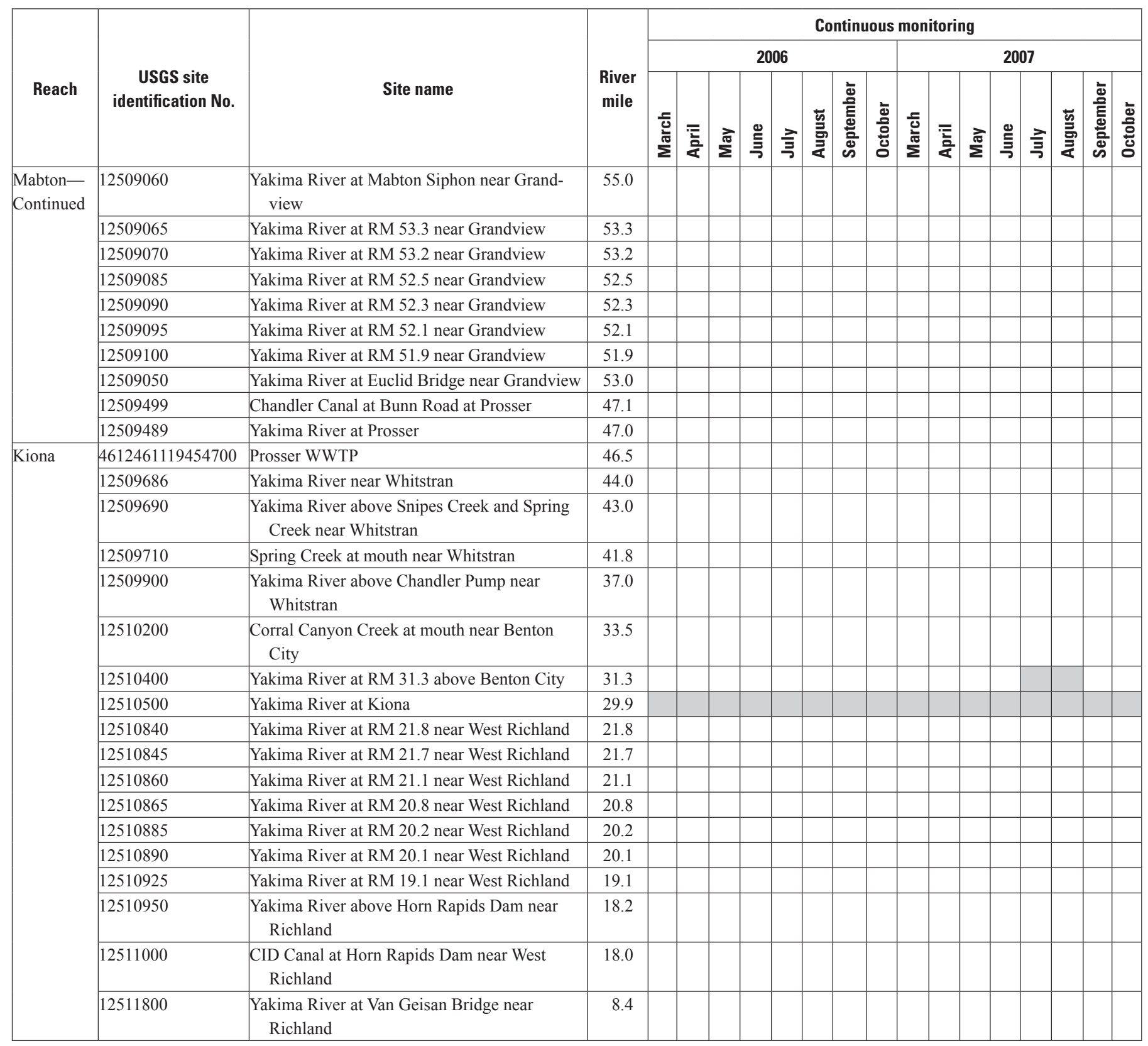


Appendix A. Study Design for the Lower Yakima River, 2005-07 


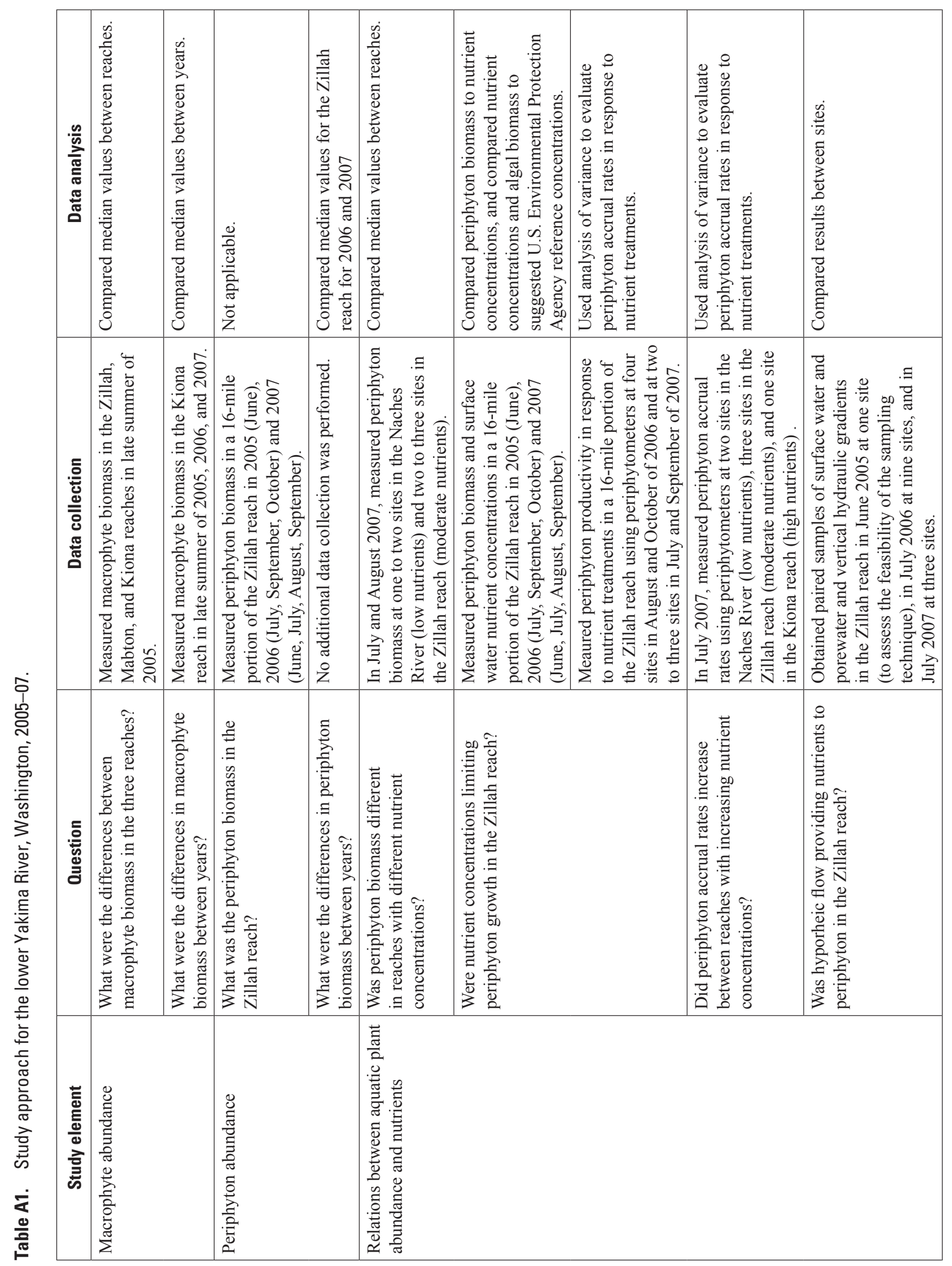




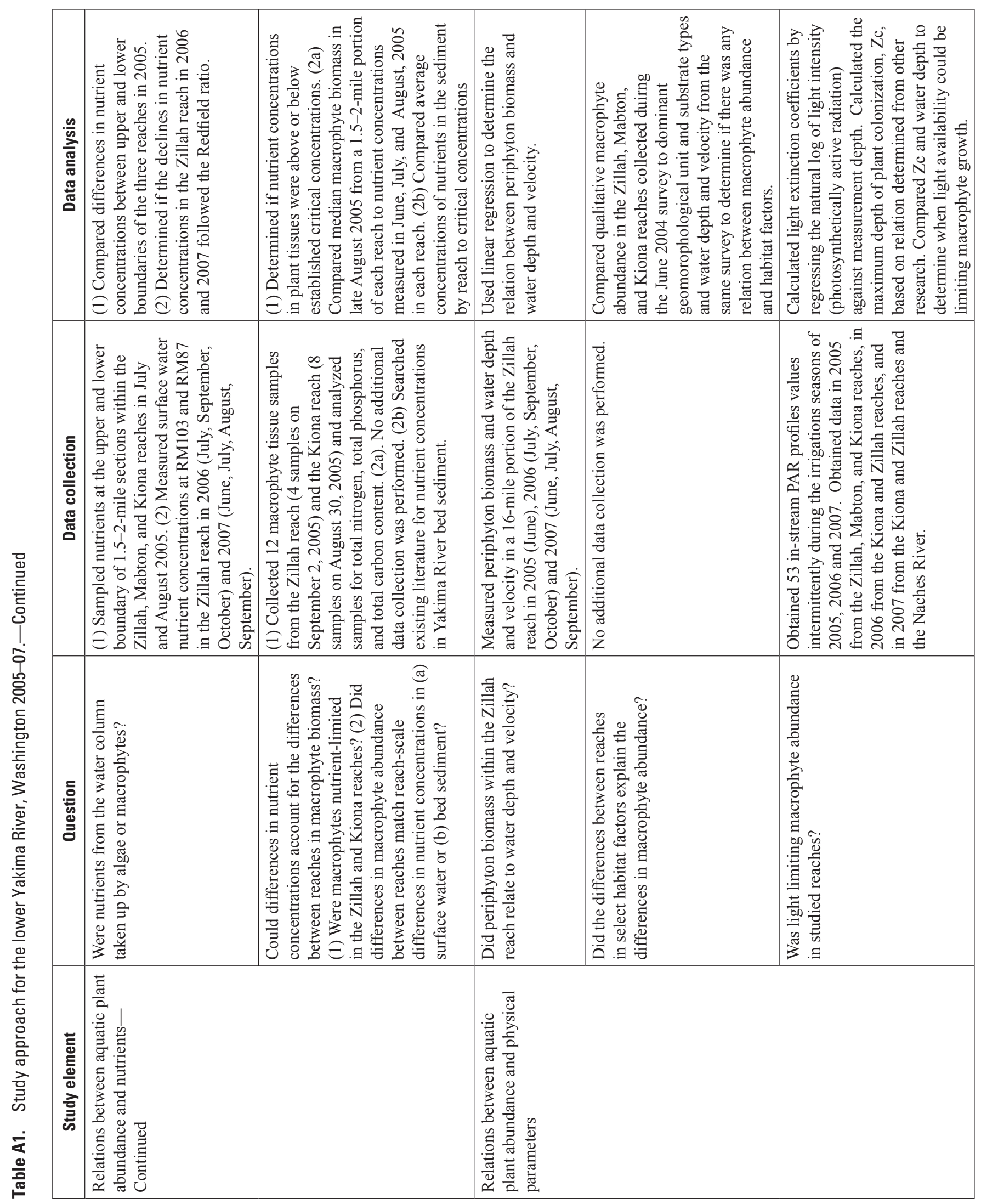




\begin{tabular}{|c|c|c|c|c|}
\hline 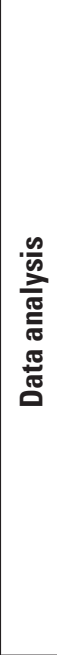 & 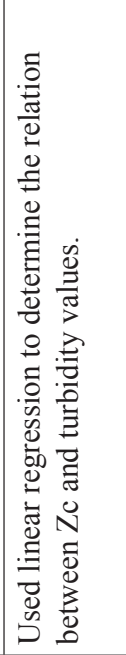 & 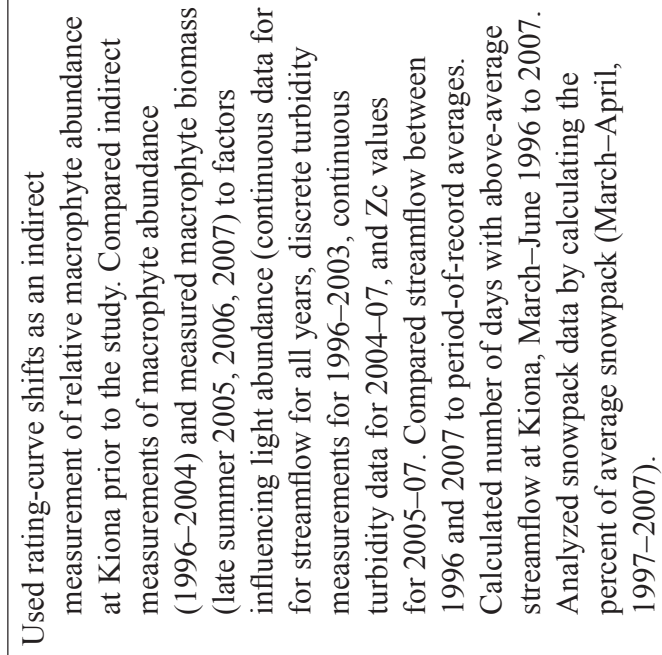 & 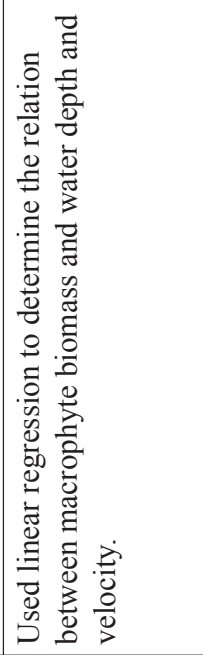 & 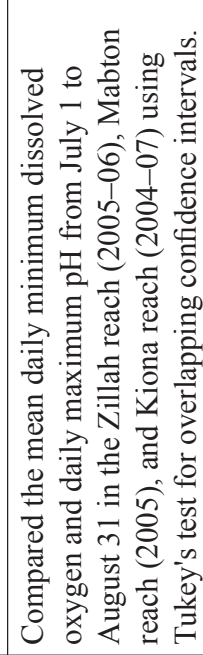 \\
\hline 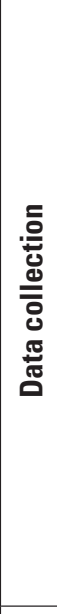 & 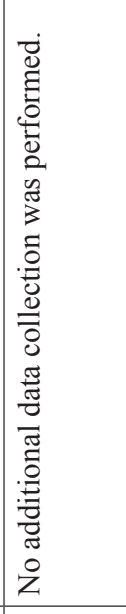 & 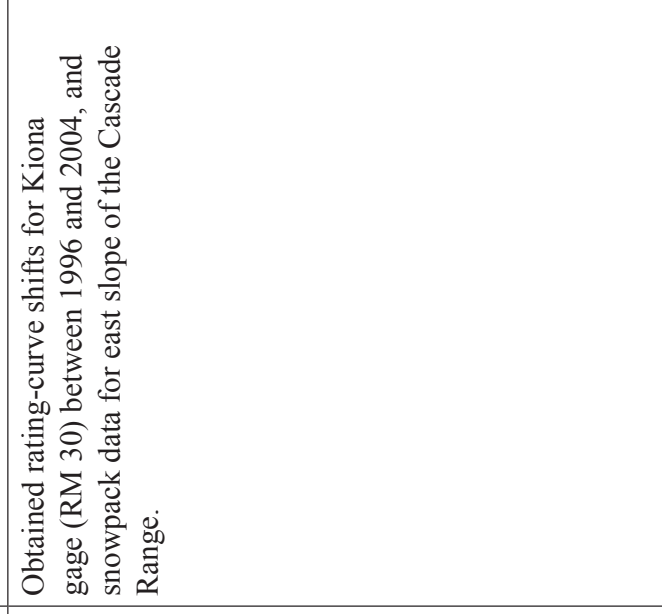 & 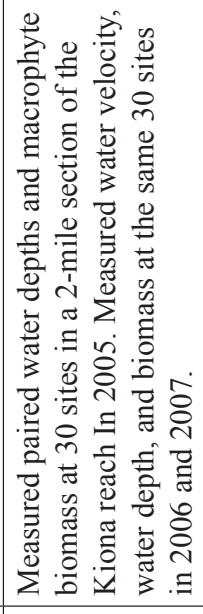 & 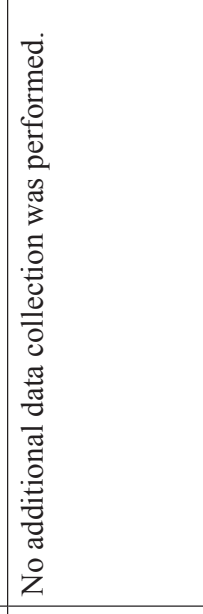 \\
\hline 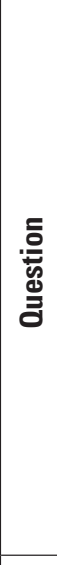 & 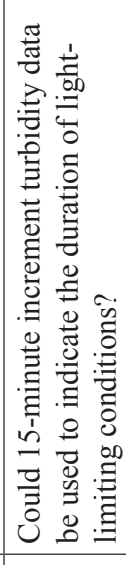 & 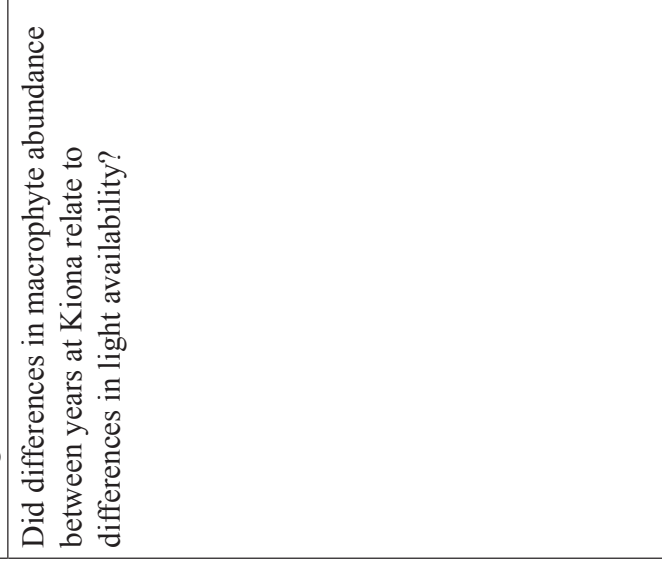 & 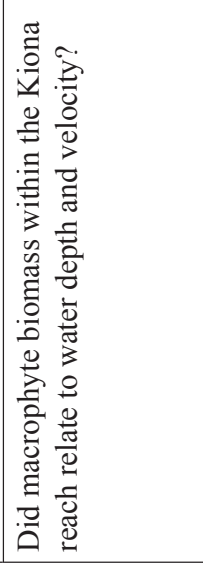 & 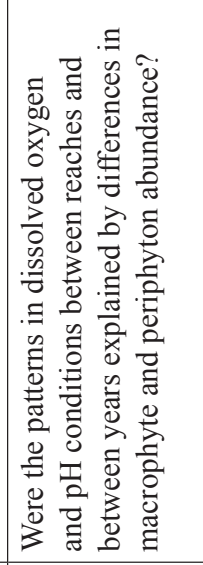 \\
\hline 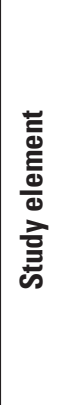 & 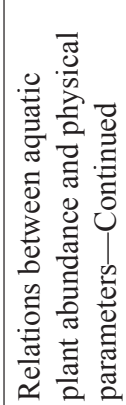 & & & 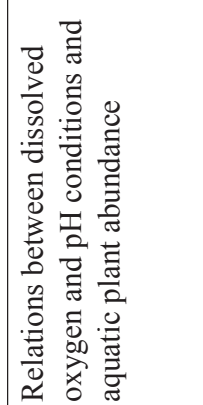 \\
\hline
\end{tabular}




\begin{tabular}{|c|c|c|c|c|c|}
\hline 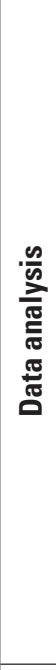 & 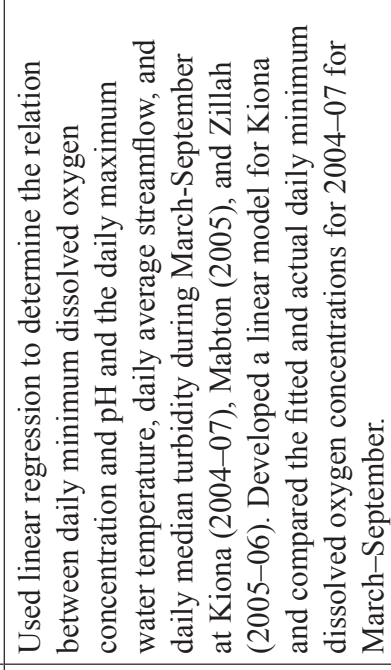 & 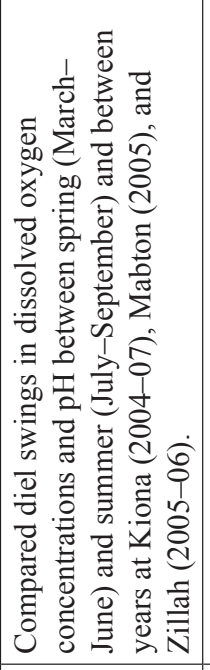 & 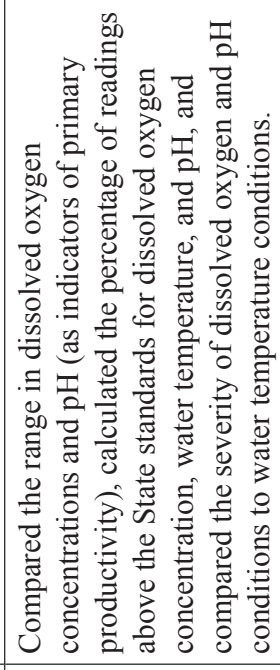 & 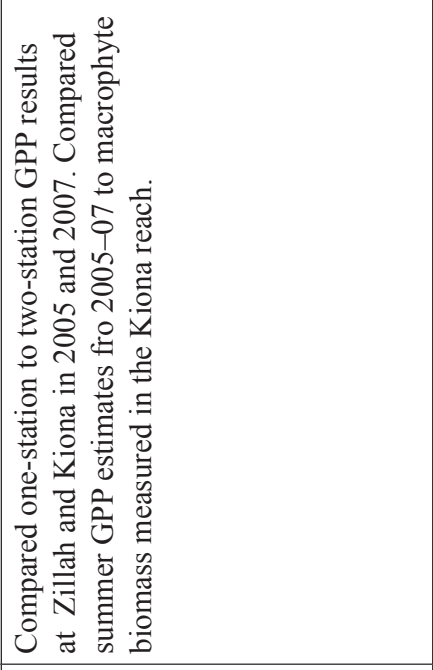 & 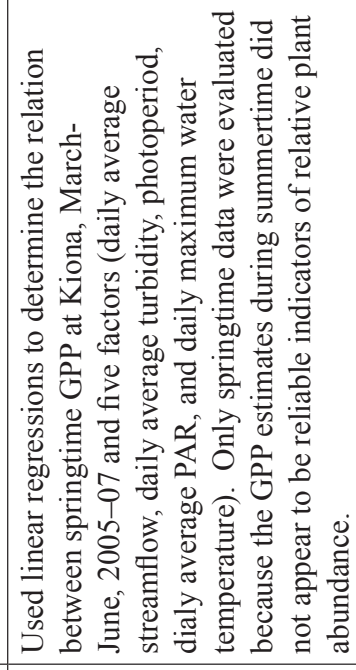 \\
\hline 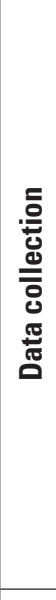 & 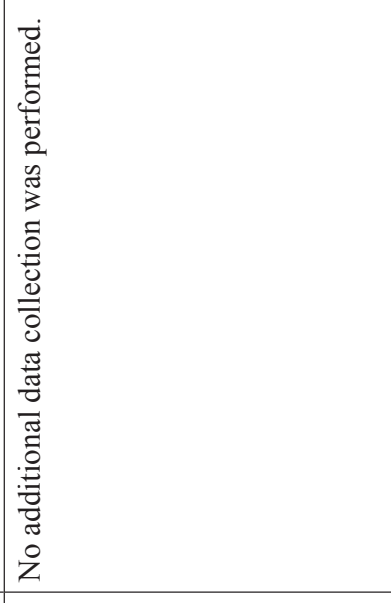 & 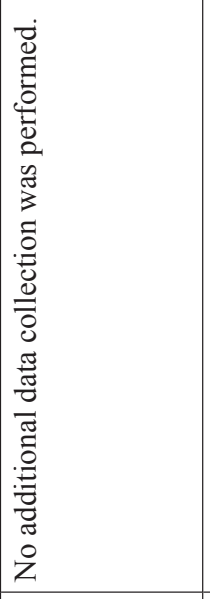 & 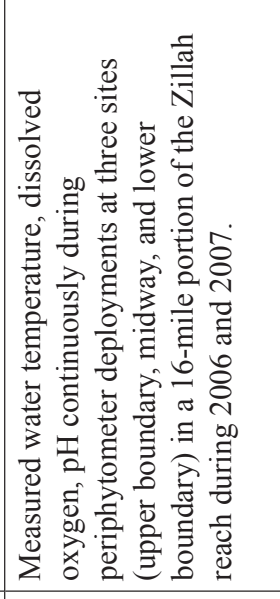 & 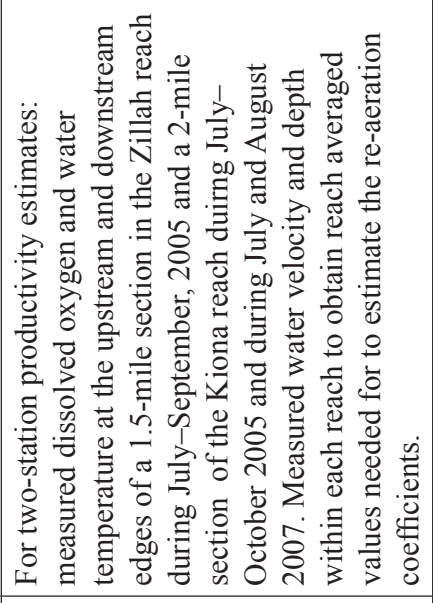 & 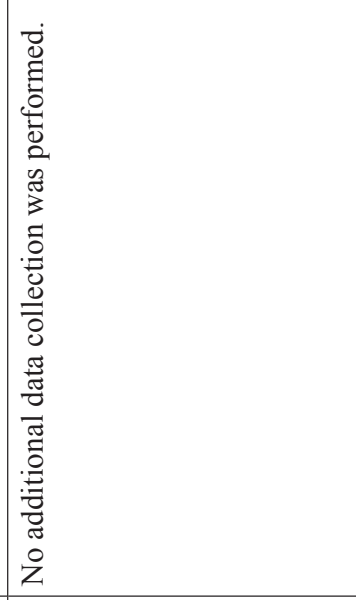 \\
\hline 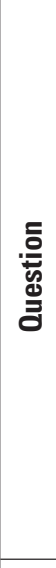 & 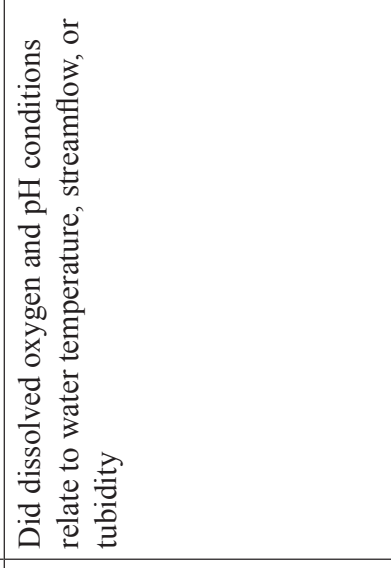 & 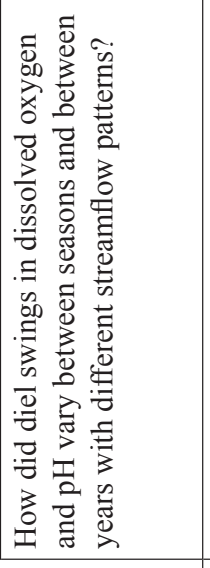 & 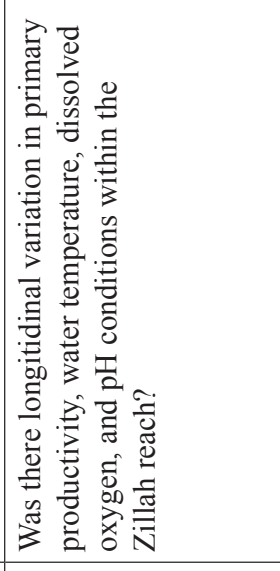 & 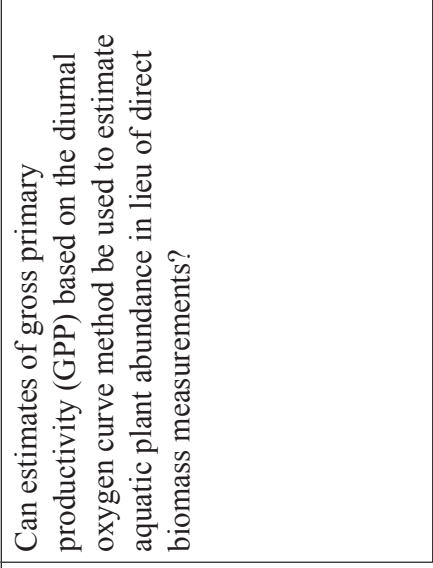 & 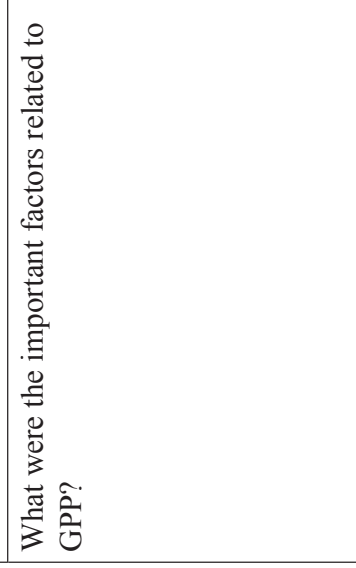 \\
\hline 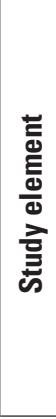 & 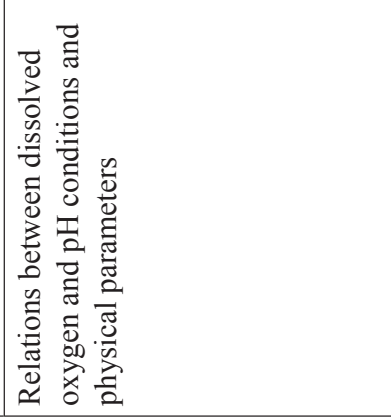 & & 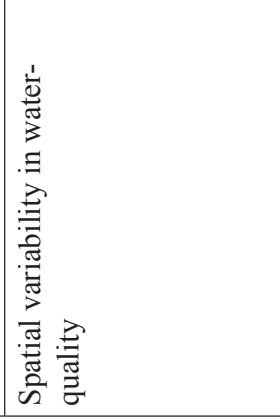 & 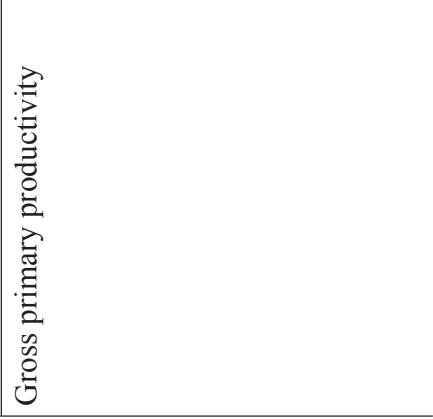 & \\
\hline
\end{tabular}




\section{Appendix B. Description of Methodology Used to Estimate Reaeration Coefficients in the Yakima River, Washington, 2005-07}

The mean depth and velocity measured on the days of the surveys performed in the Kiona reach during July 2005 and July 2007 were equal to the mean values at the Kiona gaging station on that day. Therefore, the daily mean values for mean depth and velocity for the Kiona gaging station (obtained from the rating curve calibrations) were assumed to be equal to the daily mean values for the reach. Because the river at Kiona flows through a well-defined, stable channel (James O'Connor, U.S. Geological Survey, written commun., 2007), these relations were assumed to be valid for the entire growing season (March 1 through September 30) and the reaeration estimates for the Kiona reach were made using these mean values and adjusting them to reflect changes in streamflow.

The mean depth and velocity measured on the day the survey was completed in the Zillah reach in July 2005 were compared to the mean values for that day at the Bureau of Reclamation gaging station at Parker which was located about 16 mi upstream of the monitor at Zillah. The daily mean values for water depth and velocity at the Parker gaging station were obtained from the rating curve calibrations (Quentin Krueter, Bureau of Reclamation, written commun., 2005). These daily mean values were used to estimate the reach-scale mean depth and velocity in the Zillah reach by applying a scaling factor, and the values were adjusted to reflect changes in streamflow (Bureau of Reclamation, 2006). The streamflow at the Parker gaging station was assumed to be equal to the streamflow at the Zillah monitor during the stable low-flow period from July through August, 2005 because (1) during the July 27, 2004, synoptic sampling daily mean streamflow at the Parker gaging station was $327 \mathrm{ft}^{3} / \mathrm{s}$ (Bureau of Reclamation, 2006) and the streamflow measured at RM 91 was $330 \mathrm{ft}^{3} / \mathrm{s}$ and (2) no major tributary inflow was measured between RM 91 and the water-quality monitor. Using this assumption allowed for an estimation of mean depth and velocity for the reach for each day during July and August 2005 and the reaeration estimates for the Zillah reach in 2005 were made using these mean values. Seepage studies in September 2001 and March 2006, however, did find differences in streamflow between RM 103 and 87, indicating variable conditions in the reach between years and seasons. Additionally, bed-moving events, such as those that likely occurred during spring 2007 (James O'Connor, US Geological Survey, written commun. 2007), may alter the streamflowvelocity-depth relation for the reach between years. These changes in hydrologic conditions meant that the scaling factor calculated in 2005 might not apply in other years. 


\section{Appendix C. Results from Quality Control Analysis for Discrete Water-Quality Sampling in the Yakima River, Washington, 2004-07}

Fourteen field equipment blank samples were analyzed for total and dissolved nutrients, including nitrogen (dissolved nitrite plus nitrate, dissolved ammonia, and total Kjeldahl nitrogen), phosphorus (SRP and total phosphorus), Chl $a$, and suspended sediment. Detections for nutrients in blank samples were sporadic and did not reveal any systemic sampling or laboratory contamination. Maximum concentrations in blank samples ranged from 0.01 to $0.02 \mathrm{mg} / \mathrm{L}$ for dissolved nitrateplus-nitrite and dissolved ammonia, whereas one TKN sample contained $0.08 \mathrm{mg} / \mathrm{L}$ (table $\mathrm{C} 1$ ). TP and SRP were not detected in any blank samples.

The mean percent relative difference between split replicate nutrient samples ranged from 4 percent for SRP to

11 percent for dissolved ammonia (table $\mathrm{C} 2$ ). High variability in a few samples could have been due to errors during field processing (incomplete homogenizing or uneven use of pipettes) or laboratory processing (incomplete grinding of samples) or analysis.
The reproducibility of periphyton biomass values was somewhat elevated, especially for phaeophytin $a$ and ash-free dry mass (table $\mathrm{C} 3$ ). The percent relative difference between replicate samples (not including split samples) ranged from about 17 percent for $\mathrm{Chl} a$ to 38 percent for phaeophytin $a$.

The reproducibility for triplicate algal biomass samples (splits) was within method tolerances, with percent differences of 8.5 percent and 4.5 percent for Chl $a$ and ash-free dry mass, respectively. Greater variation in the phaeophytin $a$ reproducibility, however, was observed (table $\mathrm{C} 4$ ).

The percent relative differences in nutrient content (as a percentage of total biomass) for the one replicate macrophyte sample were 8.6 percent and 4.3 percent for total nitrogen and total phosphorus, respectively (table $\mathrm{C} 5$ ). 
Table C1. Quality-control results for nutrients, chlorophyll a, and suspended sediment in field blank samples, lower Yakima River Basin, Washington, 2004-07.

[All concentrations in milligrams per liter. Values in bold indicate detections. Abbreviations: RM, river mile; EWI, equal width and depth integrated sample; $\mathrm{N}$, nitrogen; P, phosphorus; $\mathrm{NO}_{3}+\mathrm{NO}_{2}-\mathrm{N}$, nitrate-plus-nitrite- $\mathrm{N}$; $\mathrm{NH}_{4}$, ammonium-N; TKN, total Kjeldahl nitrogen; SRP, soluble reactive phosphorus; TP, total phosphorus; TOC, total organic carbon; Chl $a$, chlorophyll $a$; SS, suspended sediment; <, less than; -, no data]

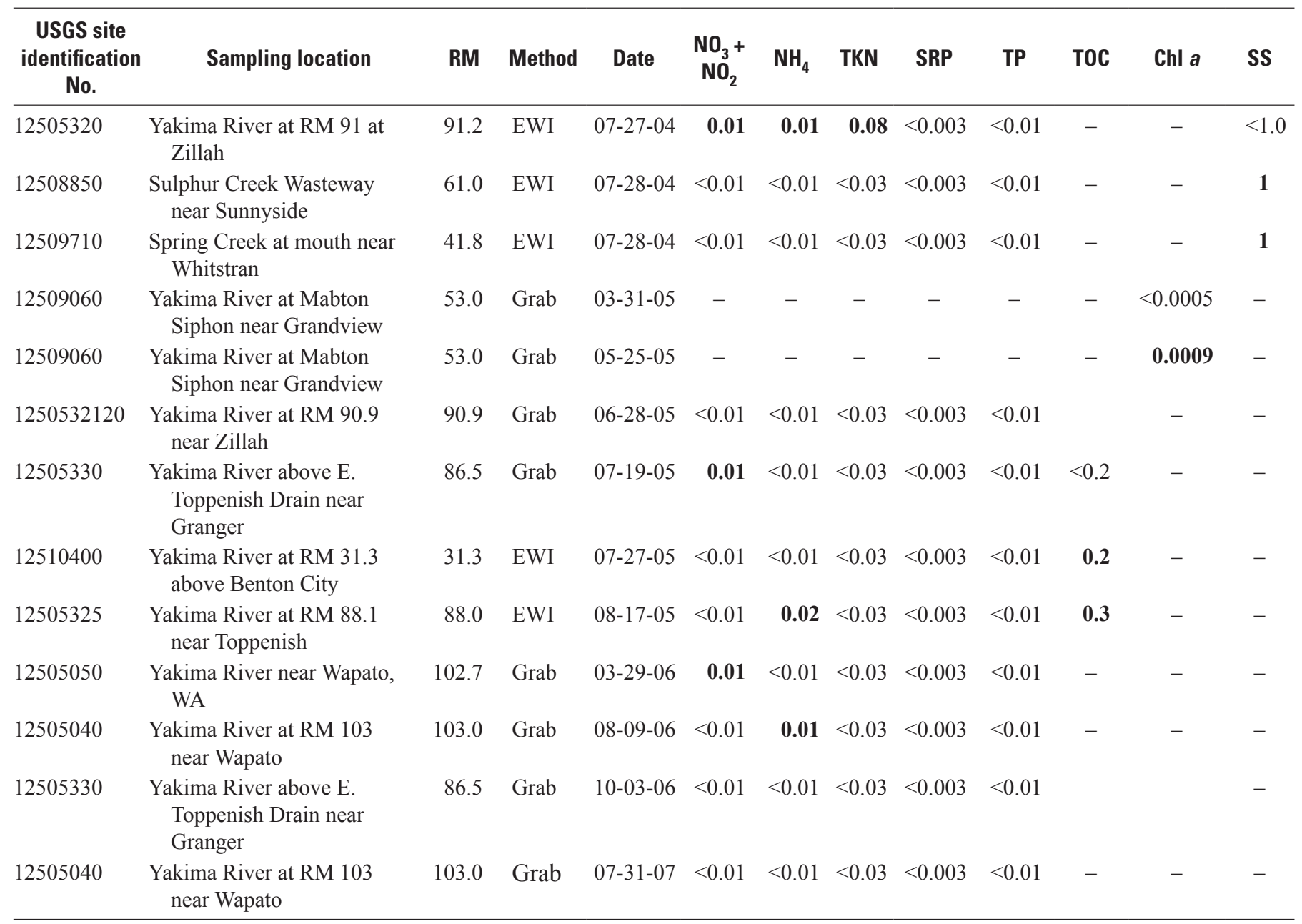




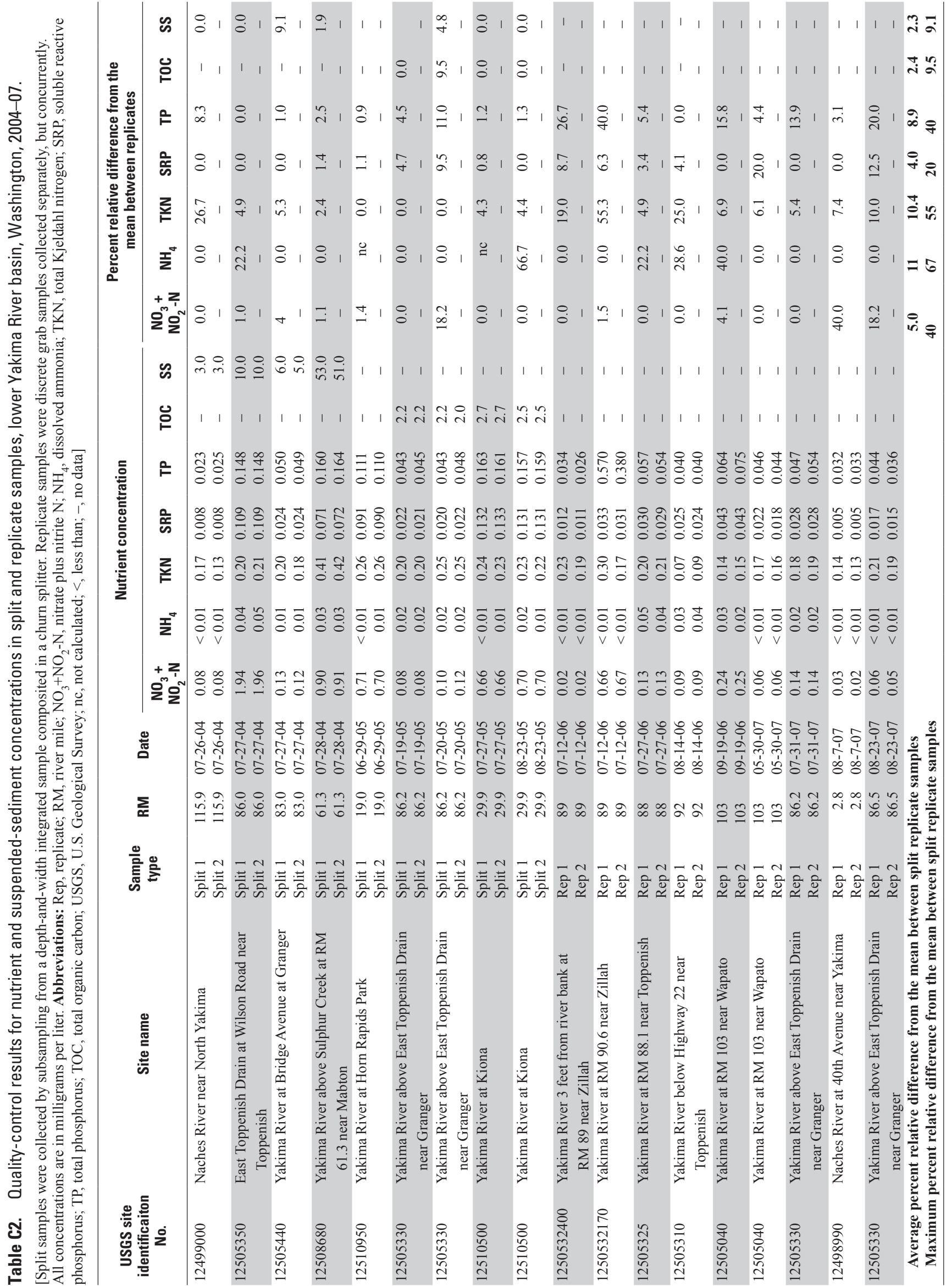




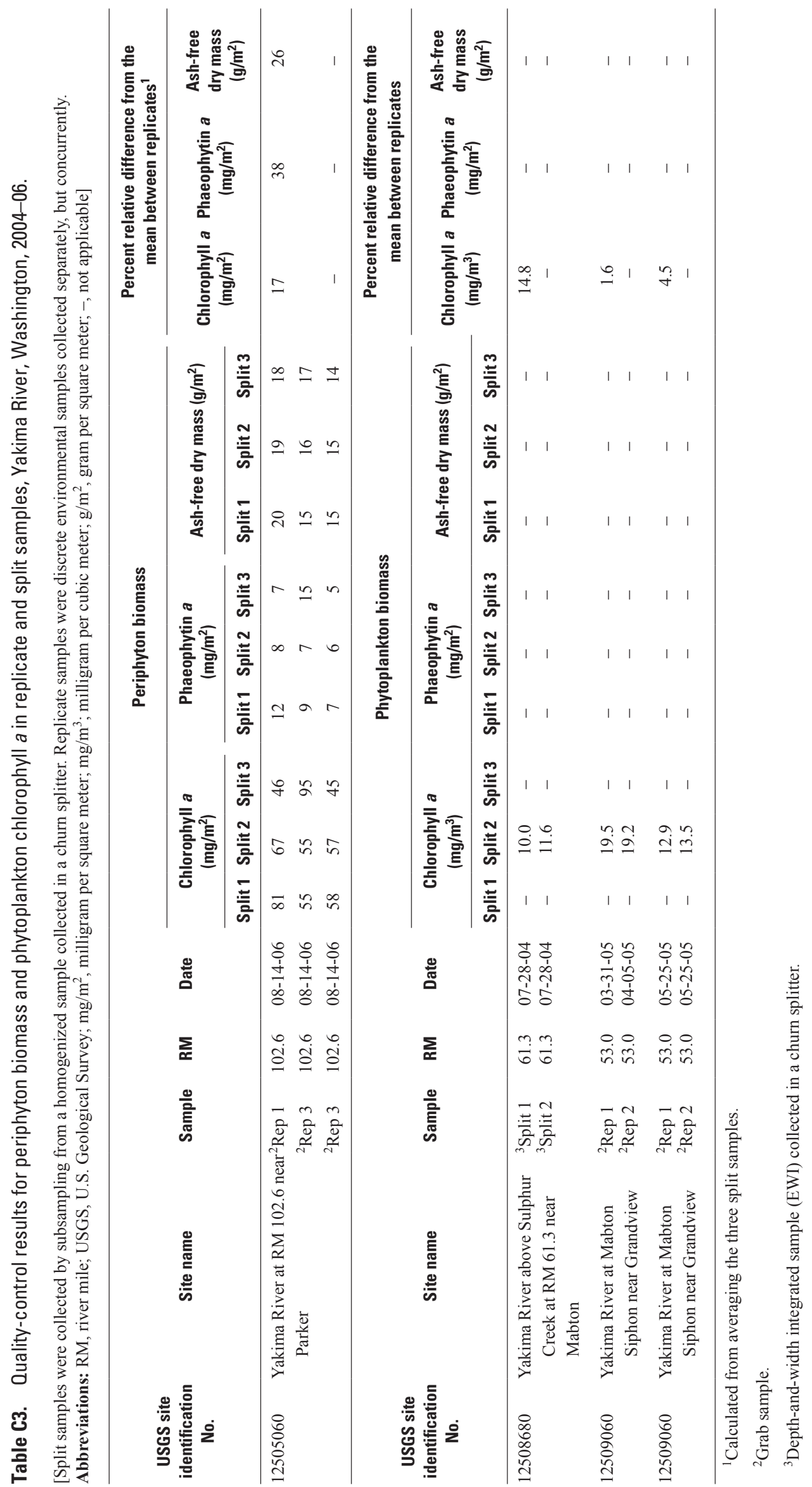




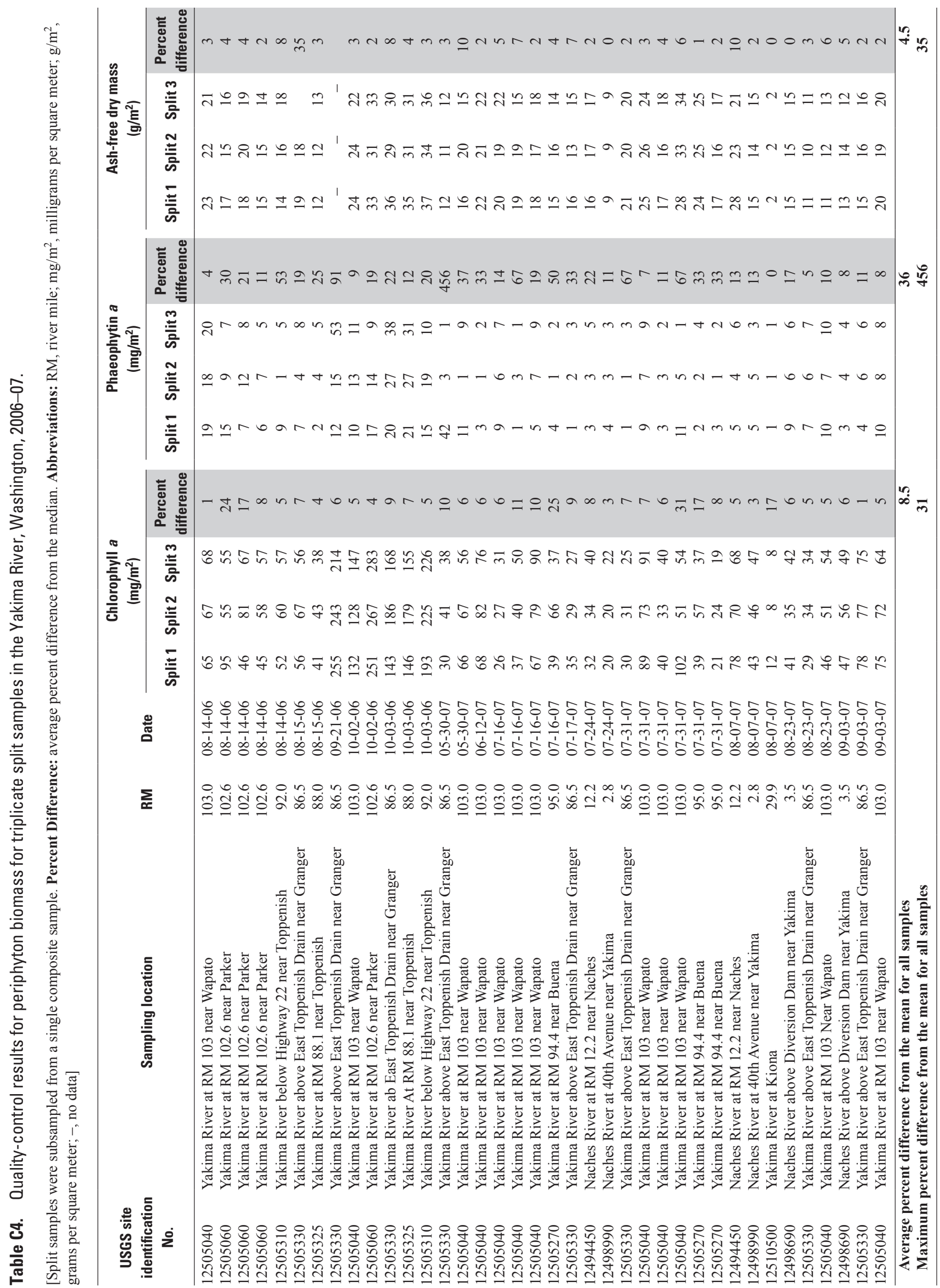


94 Assessment of Eutrophication in the Lower Yakima River Basin, Washington, 2004-07

Table C5. Quality-control results for replicate nutrient content in macrophyte samples in the Yakima River at river mile 18, Washington, August 30, 2005.

[Replicate samples were collected independently. Abbreviation: Rep, replicate; -, no data]

\begin{tabular}{ccccccc}
\hline \multirow{2}{*}{$\begin{array}{c}\text { Sample } \\
\text { type }\end{array}$} & \multicolumn{2}{c}{$\begin{array}{c}\text { Macrophyte biomass } \\
\text { (percent) }\end{array}$} & & \multicolumn{2}{c}{$\begin{array}{c}\text { Percent relative difference } \\
\text { from the mean between } \\
\text { replicates }\end{array}$} \\
\cline { 2 - 3 } \cline { 5 - 6 } & $\begin{array}{c}\text { Total } \\
\text { nitrogen }\end{array}$ & $\begin{array}{c}\text { Total } \\
\text { phosphorus }\end{array}$ & & $\begin{array}{c}\text { Total } \\
\text { nitrogen }\end{array}$ & $\begin{array}{c}\text { Total } \\
\text { phosphorus }\end{array}$ \\
\hline Rep 1 & 2.6 & 0.45 & & 8.6 & 4.3 \\
Rep 2 & 2.8 & 0.47 & & - & - \\
\hline
\end{tabular}




\section{Appendix D. Results from Quality Control Analysis for Continuous Monitoring of Water Temperature, Specific Conductance, Dissolved Oxygen, pH, Turbidity, and Total Chlorophyll in the Yakima River, Washington, 2004-07}

The USGS guidelines for continuous monitor operation specify that continuous water-quality data be corrected by applying calibration and (or) fouling corrections that are determined during routine monitor maintenance or when a monitor is removed from service. A correction for a parameter is required when the sum of the absolute values for calibration and fouling drift error exceeds the value shown in table D1 (no data-correction criterion exists for total chlorophyll).

Data quality ratings for the monitor deployments were determined by considering two factors: (1) how closely the operation and maintenance for the monitors followed the specifications in the USGS guidelines, and (2) the sum of the absolute values of the calibration and fouling corrections applied to the data. Table D2 shows the ratings for the monitor deployments at Kiona between 2004 and 2007, the spring and summer monitor deployment at Mabton in 2005, and the spring and summer monitor deployments at Zillah in 2006 and 2007.

To determine how representative the data obtained from the monitor were of the entire stream, cross-sectional measurements were made at the monitoring sites for temperature, specific conductance, dissolved oxygen, and $\mathrm{pH}$ at Kiona in 2004-07, Mabton in 2005, Zillah in 2005-06, and many of the short-term sites monitored in 2004. The results are shown in table D3.

Table D4 summarizes the differences between the Clark cell and optical dissolved oxygen probes during the period when both probes were in use.

Table D1. U.S. Geological Survey criteria for water-quality data corrections.

[Data-correction criteria from Wagner and others, 2006. No data-correction criterion for total chlorophyll. Abbreviations: ${ }^{\circ} \mathrm{C}$, degrees Celsius; $\mu \mathrm{S} / \mathrm{cm}$, micosiemens per centimeter; \pm , plus or minus; $\mathrm{mg} / \mathrm{L}$, milligram per liter; NTU, Nephelometric Turbidity Unit]

\begin{tabular}{ll}
\hline \multicolumn{1}{c}{ Parameter } & \multicolumn{1}{c}{ Data-correction criteria } \\
\hline Temperature & $\pm 0.2^{\circ} \mathrm{C}$ \\
Specific conductance & $\begin{array}{c}\text { The greater of }+5 \mu \mathrm{S} / \mathrm{cm} \text { or } \pm 3 \text { percent of the } \\
\text { measured value, whichever is greater } \\
\end{array}$ \\
Dissolved oxygen & $\pm 0.3 \mathrm{mg} / \mathrm{L}$ \\
$\mathrm{pH}$ & $\pm 0.2 \mathrm{pH}$ units \\
Turbidity & The greater of $\pm 2 \mathrm{NTU}$ or \pm 5 percent of the \\
& measured value, whichever is greater \\
\hline
\end{tabular}


Table D2. Quality control ratings for continuous water-quality monitoring gaging stations, Yakima River at Kiona, water years 2004-07, Mabton, 2005, and Zillah, Washington, 2005-06.

[Values represent the percentage of time when the monitor was deployed when data were rated as excellent, good, fair, and poor. na, not applicable; -, no data]

\begin{tabular}{|c|c|c|c|c|c|c|c|c|}
\hline \multirow{3}{*}{ Rating } & \multicolumn{8}{|c|}{ Water year } \\
\hline & \multirow{2}{*}{$\begin{array}{c}2004 \\
\text { Kiona }\end{array}$} & \multicolumn{3}{|c|}{2005} & \multicolumn{3}{|c|}{2006} & \multirow{2}{*}{$\begin{array}{l}2007 \\
\text { Kiona }\end{array}$} \\
\hline & & Kiona & Mabton & Zillah & Kiona & $\begin{array}{l}\text { Kiona- } \\
\text { optical }\end{array}$ & Zillah & \\
\hline \multicolumn{9}{|c|}{ Water temperature, in degrees Celsius } \\
\hline Excellent & 0 & 100 & 100 & 100 & 100 & - & 100 & 100 \\
\hline Good & 100 & 0 & 0 & 0 & 0 & - & 0 & 0 \\
\hline Fair & 0 & 0 & 0 & 0 & 0 & - & 0 & 0 \\
\hline Poor & 0 & 0 & 0 & 0 & 0 & - & 0 & 0 \\
\hline \multicolumn{9}{|c|}{ Specific conductance, in microsiemens per centimeter } \\
\hline Excellent & 0 & 68 & 100 & 100 & 57 & - & 100 & 50 \\
\hline Good & 100 & 27 & 0 & 0 & 38 & - & 0 & 40 \\
\hline Fair & 0 & 6 & 0 & 0 & 4 & - & 0 & 5 \\
\hline Poor & 0 & 0 & 0 & 0 & 0 & - & 0 & 5 \\
\hline \multicolumn{9}{|c|}{ Dissolved oxygen, in milligrams per liter } \\
\hline Excellent & 0 & 0 & 0 & 27 & ${ }^{1} 75$ & 100 & 70 & 95 \\
\hline Good & 85 & 72 & 47 & 32 & ${ }^{1} 18$ & 0 & 18 & 4 \\
\hline Fair & 9 & 14 & 31 & 11 & ${ }^{15}$ & 0 & 7 & 1 \\
\hline Poor & 6 & 14 & 22 & 30 & ${ }^{1} 2$ & 0 & 5 & 0 \\
\hline \multicolumn{9}{|c|}{$\mathrm{pH}$, in standard units } \\
\hline Excellent & 0 & 64 & 83 & 87 & 78 & - & 87 & 87 \\
\hline Good & 100 & 27 & 17 & 13 & 19 & - & 13 & 13 \\
\hline Fair & 0 & 8 & 0 & 0 & 3 & - & 0 & 0 \\
\hline Poor & 0 & 0 & 0 & 0 & 0 & - & 0 & 0 \\
\hline \multicolumn{9}{|c|}{ Turbidity, in nephelometric turbidity units } \\
\hline Excellent & 0 & 0 & 100 & 43 & 94 & - & 100 & 51 \\
\hline Good & 100 & 51 & 0 & 57 & 1 & - & 0 & 21 \\
\hline Fair & 0 & 26 & 0 & 0 & 1 & - & 0 & 11 \\
\hline Poor & 0 & 13 & 0 & 0 & 5 & - & 0 & 16 \\
\hline \multicolumn{9}{|c|}{ Total chlorophyll, in micrograms per liter } \\
\hline Excellent & 0 & 0 & 0 & 0 & 87 & - & na & na \\
\hline Good & 0 & 79 & 78 & 23 & 2 & - & na & na \\
\hline Fair & 100 & 21 & 22 & 25 & 2 & - & na & na \\
\hline Poor & 0 & 0 & 0 & 52 & 9 & - & na & na \\
\hline
\end{tabular}

${ }^{1}$ Clark cell. 
Table D3. Cross-sectional measurements of water temperature, specific conductance, dissolved oxygen, and pH, Yakima River, Washington, 2004-07.

[The Kiona and Zillah monitors were installed near the left bank of the river; the Mabton monitor was installed at the center of the river. The Kiona bridge is 630 feet downstream of the Kiona monitor. Abbreviations: RM, river mile; ${ }^{\circ} \mathrm{C}$, degrees Celsius; $\mu \mathrm{S} / \mathrm{cm}$, microsiemens per centimeter; $\mathrm{mg} / \mathrm{L}$, milligram per liter]

\begin{tabular}{|c|c|c|c|c|c|}
\hline \multirow[b]{2}{*}{ Location } & \multirow[b]{2}{*}{ Measurement } & \multicolumn{4}{|c|}{ Parameter } \\
\hline & & $\begin{array}{l}\text { Temperature } \\
\left({ }^{\circ} \mathrm{C}\right)\end{array}$ & $\begin{array}{l}\text { Specific } \\
\text { conductance } \\
(\mu S / \mathrm{cm})\end{array}$ & $\begin{array}{l}\text { Dissolved } \\
\text { oxygen } \\
\text { (mg/L) }\end{array}$ & $\begin{array}{l}\text { pH } \\
\text { (standard } \\
\text { units) }\end{array}$ \\
\hline \multicolumn{6}{|c|}{ Yakima River at Kiona (RM 30; 12510500), 2004-07-27 comparisons } \\
\hline $\begin{array}{l}\text { Maximum absolute difference between monitor reading and cross- } \\
\text { sectional readings taken downstream at Kiona bridge. }\end{array}$ & Median & 0.10 & 4 & 0.69 & 0.12 \\
\hline $\begin{array}{l}\text { Maximum absolute difference between monitor reading and } \\
\text { reading taken at left bank of river at Kiona bridge. }\end{array}$ & 90th percentile & 0.37 & 10 & 2.04 & 0.36 \\
\hline \multirow{2}{*}{$\begin{array}{l}\text { Maximum absolute difference between reading taken one foot } \\
\text { from the bottom and one foot from the surface at the Kiona } \\
\text { bridge. }\end{array}$} & Median & 0.01 & 0 & 0.01 & 0.01 \\
\hline & 90th percentile & 0.02 & 0 & 0.05 & 0.02 \\
\hline $\begin{array}{l}\text { Differences between 1-foot from the bottom and 1-foot from the } \\
\text { surface at the Mabton siphon. }\end{array}$ & Median & 0.00 & 0 & 0.02 & 0.01 \\
\hline \multicolumn{6}{|c|}{ Yakima River above East Toppenish Drain near Granger (Zillah; RM 87; 12505330), 2005-06_9 comparisons } \\
\hline $\begin{array}{l}\text { Differences between the monitor location and } \\
\text { cross-section stations. }\end{array}$ & Median & 0.13 & 1 & 0.70 & 0.12 \\
\hline $\begin{array}{l}\text { Differences between the monitor location and } \\
\text { cross-section stations. }\end{array}$ & 90th percentile & 0.28 & 3 & 1.40 & 0.84 \\
\hline \multicolumn{6}{|c|}{ Maximum absolute difference across the cross-section at various sites, 2004} \\
\hline $\begin{array}{l}\text { 12487000 Yakima River at Selah Gap near North Yakima } \\
\text { (RM 117). }\end{array}$ & Single values & 0.31 & 6 & 0.67 & 0.03 \\
\hline $\begin{array}{l}12511000 \text { CID Canal at Horn Rapids Dam near West Richland } \\
\text { (RM 18). }\end{array}$ & Single values & 0.01 & 0 & 0.03 & 0.01 \\
\hline $\begin{array}{l}12511800 \text { Yakima River at Van Giesen Bridge near Richland } \\
\text { (RM 8). }\end{array}$ & Single values & 0.12 & 1 & 0.61 & 0.06 \\
\hline
\end{tabular}


Table D4. Comparison of concurrent dissolved oxygen measurements made by a Clark cell probe and optical probe at the Yakima River at Kiona (river mile 30), Washington, July 6, 2006February 1, 2007.

\begin{tabular}{lccc}
\hline \multirow{2}{*}{ Parameter } & \multicolumn{2}{c}{ Daily dissolved oxygen concentration } \\
\cline { 2 - 4 } & Minimum & Mean & Maximum \\
\hline $\begin{array}{c}\text { 10th percentile of difference } \\
\text { (optical-Clark) }\end{array}$ & -0.20 & -0.18 & -0.20 \\
$\begin{array}{c}\text { Median of difference } \\
\text { (optical-Clark) }\end{array}$ & 0.05 & 0.07 & 0.15 \\
$\begin{array}{l}\text { 90th percentile of difference } \\
\text { (optical-Clark) }\end{array}$ & 0.40 & 0.39 & 0.60 \\
\hline
\end{tabular}


Appendix E. Mass Balances for Instantaneous Streamflows, Total Nitrogen Loads, Total Phosphorus Loads, and Suspended Sediment Loads in the Main Stem, Selected Major Tributaries, and Canals, Yakima River Basin, Washington, July 26-29, 2004 


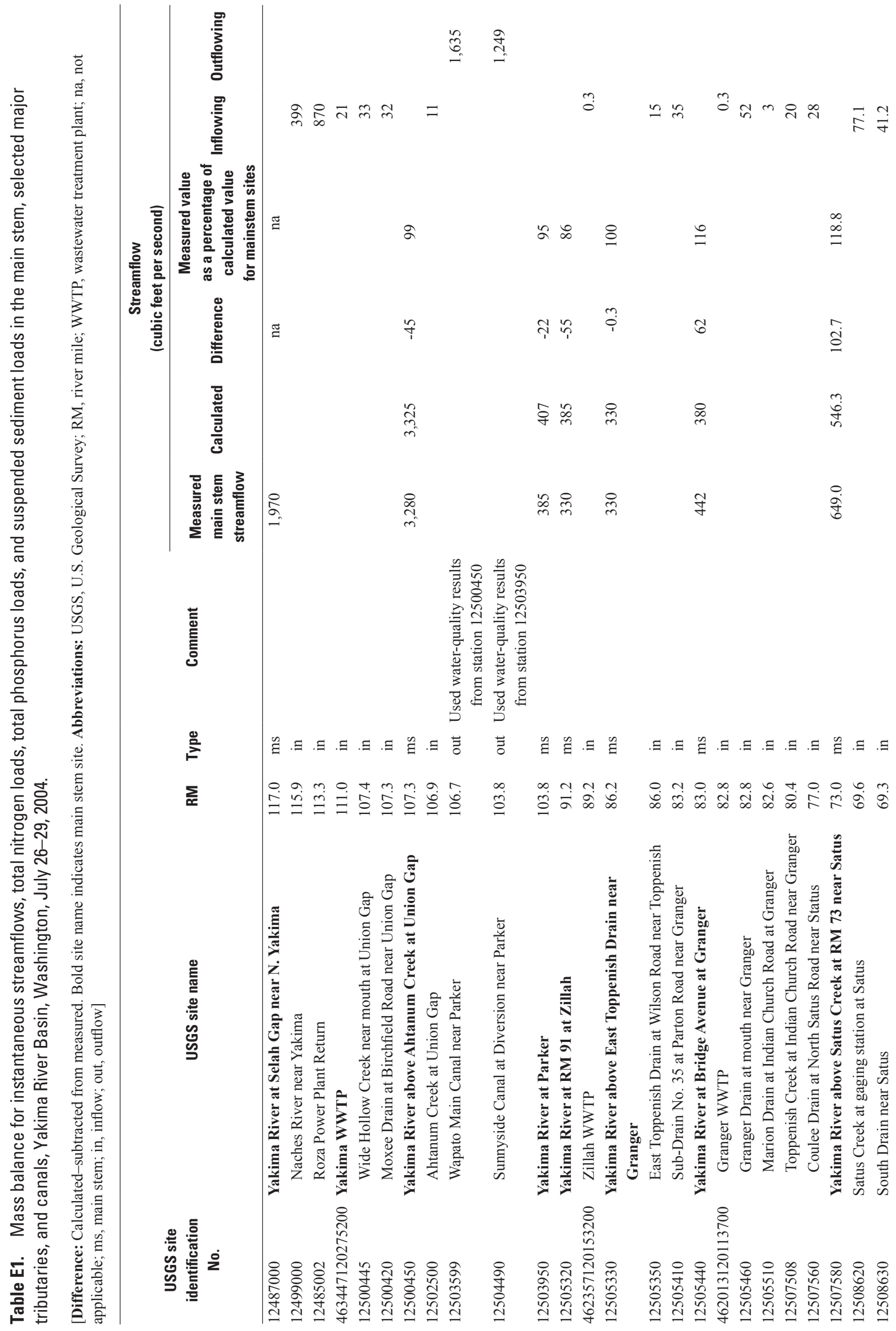




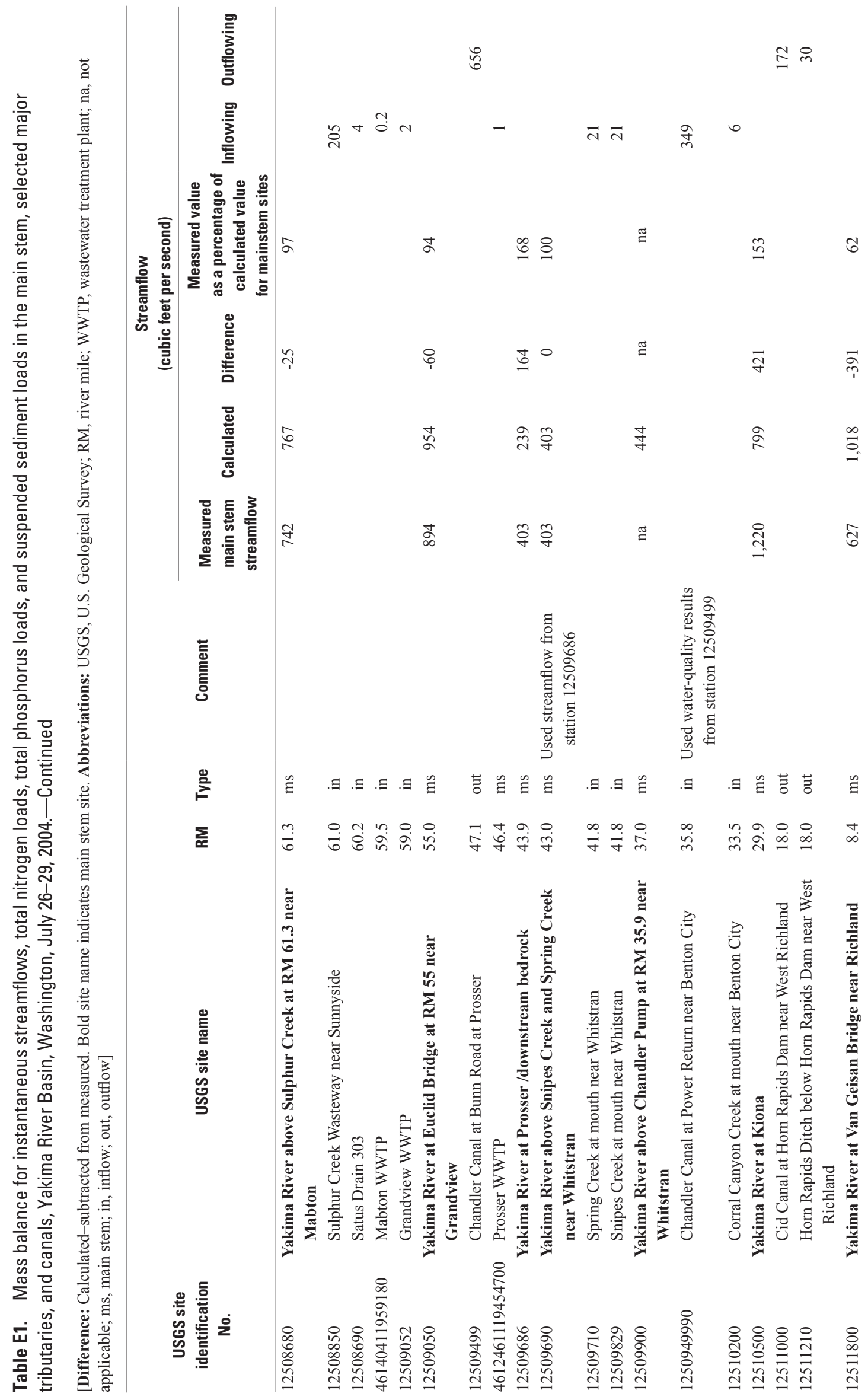




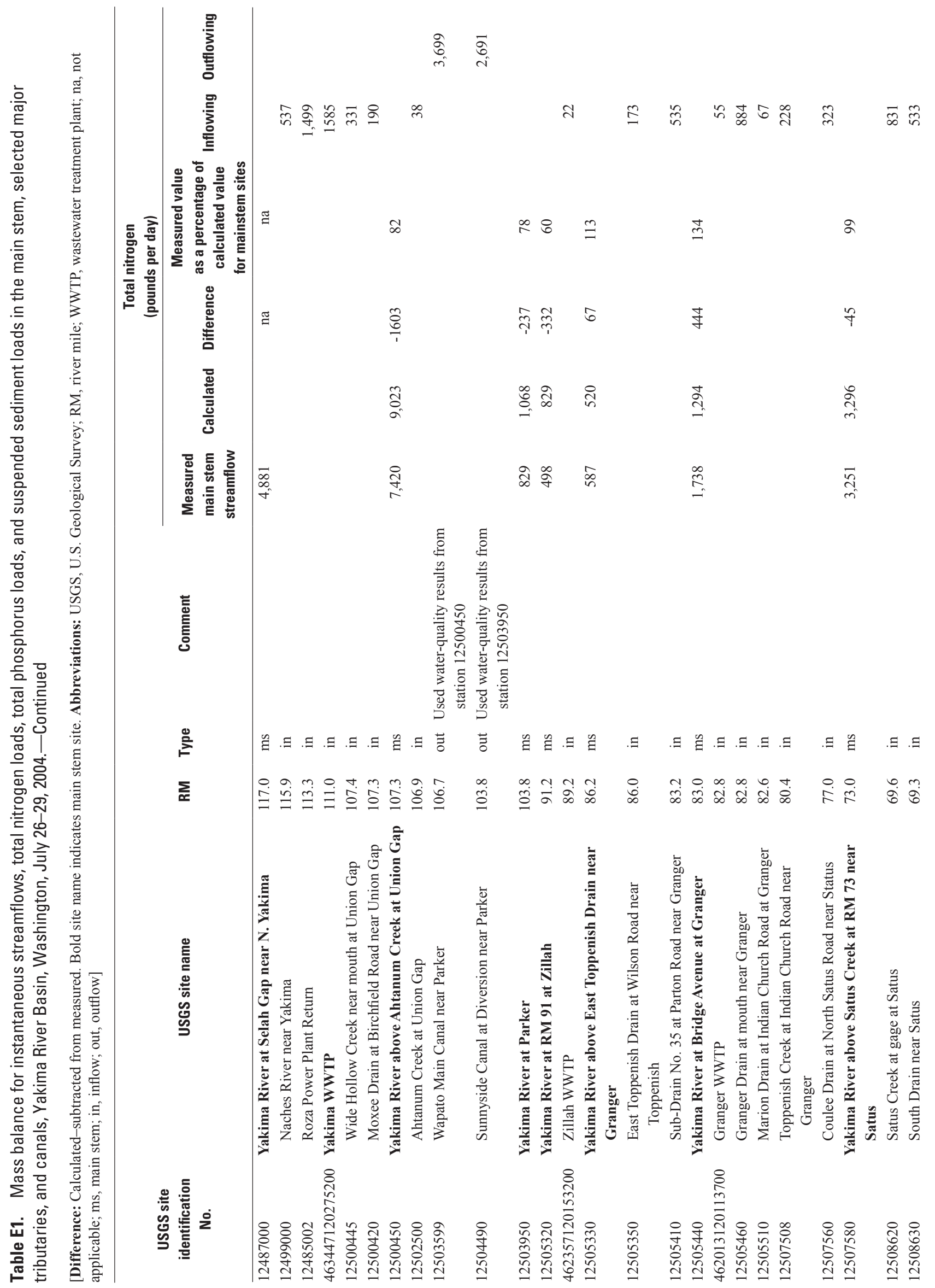




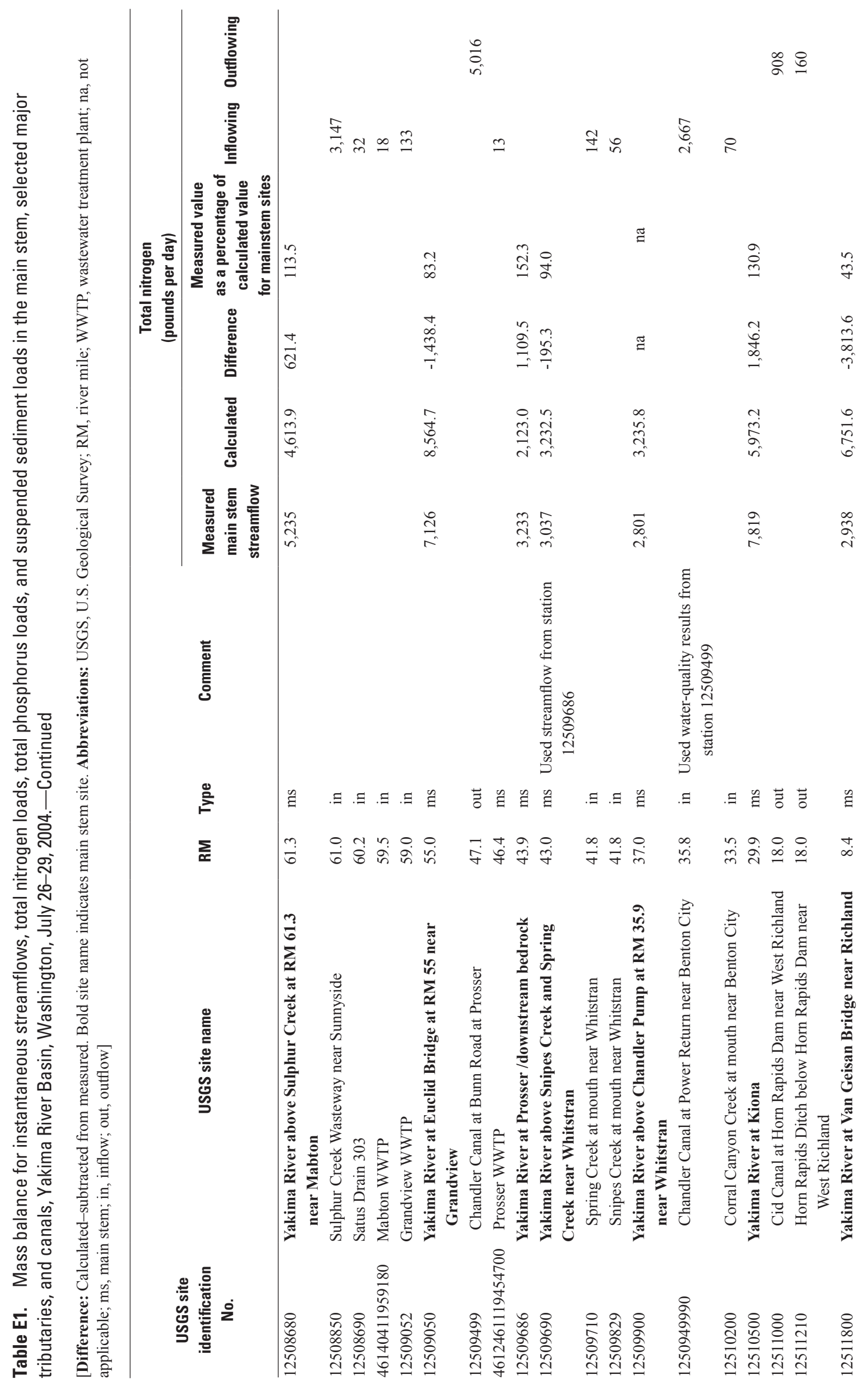




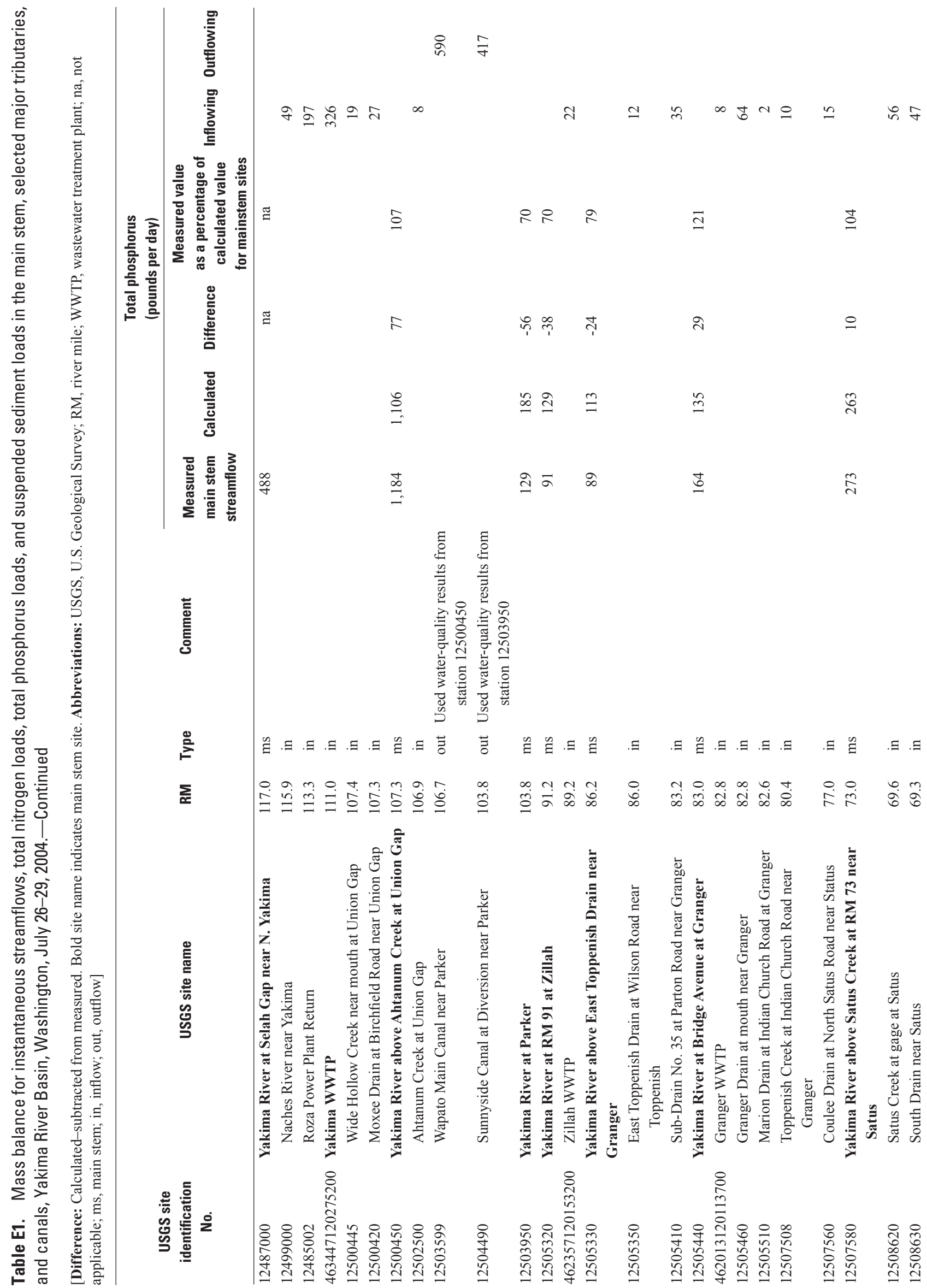




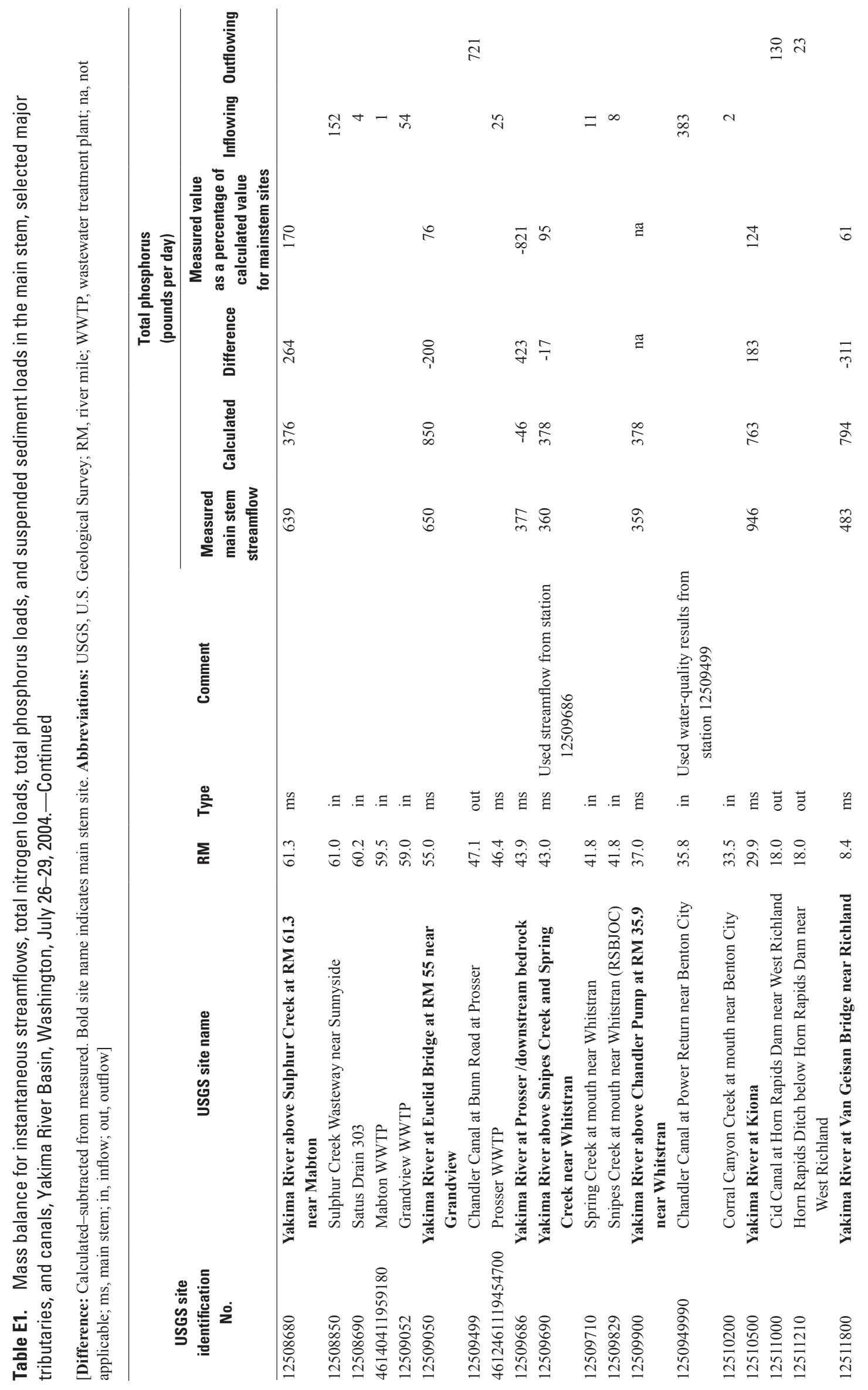




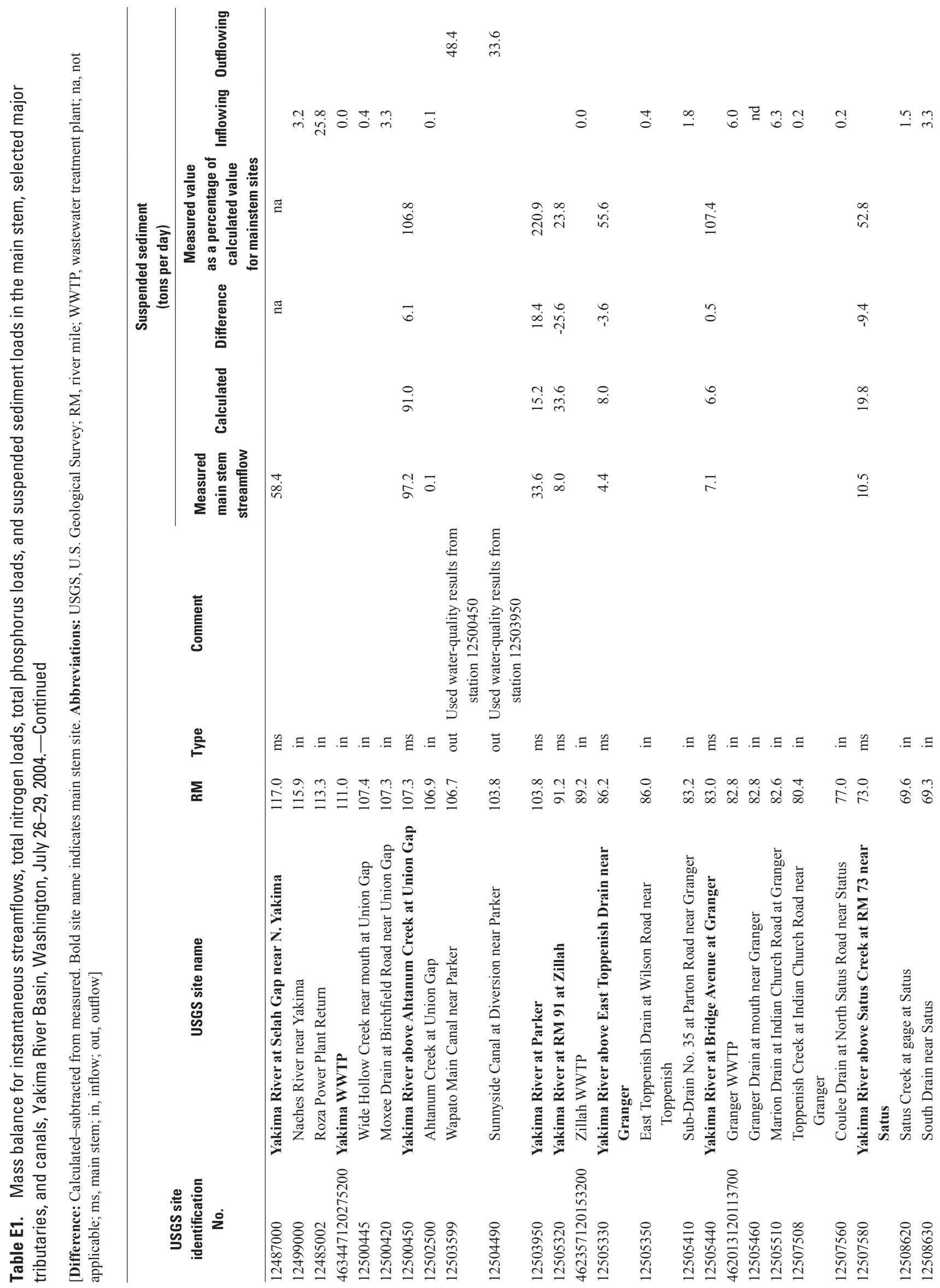




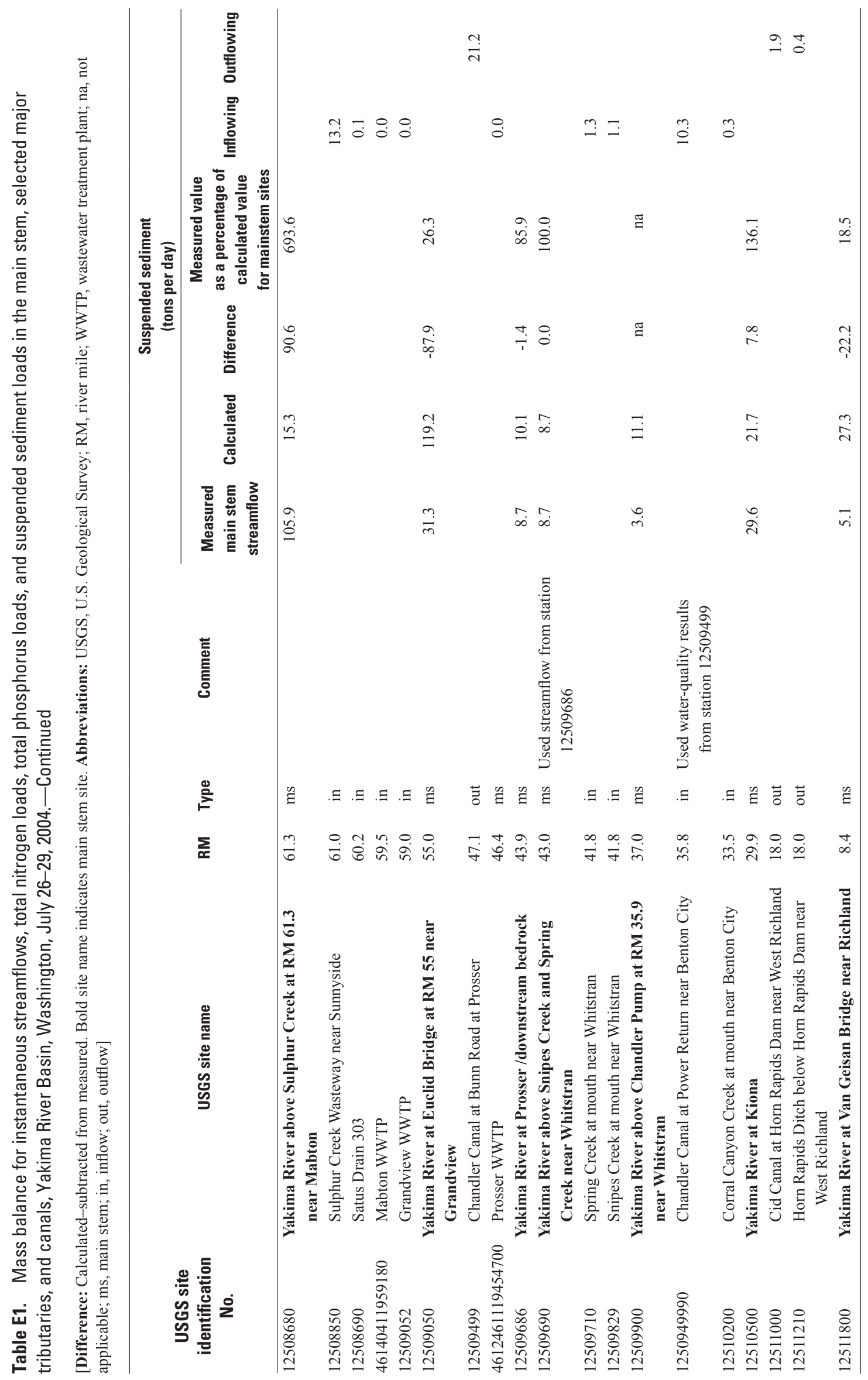


This page intentionally left blank. 
Publishing support provided by the U.S. Geological Survey

Publishing Network, Tacoma Publishing Service Center

For more information concerning the research in this report, contact the Director, Oregon Water Science Center

U.S. Geological Survey

2130 SW 5th Avenue

Portland, Oregon 97201

http://or.water.usgs.gov 
웋

ㄱ.

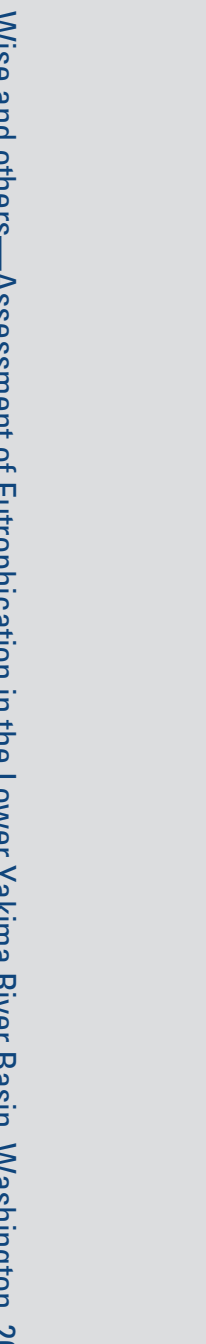

政

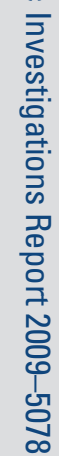

